UNIVERSIDADE DE SÃO PAULO

INSTITUTO DE GEOCIÊNCIAS

\title{
RECONSTITUIÇÃO PALEOAMBIENTAL \\ DAS ENSEADAS DO FLAMENGO E DA FORTALEZA, UBATUBA, S.P., DURANTE O HOLOCENO, INFERIDA A PARTIR DA VARIAÇÃO DAS ASSOCIAÇÕES DE FORAMINÍFEROS
}

\author{
Juliana Braga Silva
}

Orientadora: Profa. Dra. Wânia Duleba

\section{DISSERTAÇÃO DE MESTRADO}

Programa de Pós-Graduação em Geologia Sedimentar

SÃO PAULO

2008 
A meus pais, Marlene e José, meus pilares. À minha irmã, Marina, minha luzinha.

E ao Vitor, meu coração. 


\section{Agradecimentos}

Agradeço à Profa. Dra. Wânia Duleba, que foi, durante todo esse tempo, além de orientadora, amiga. Obrigada por tudo o que me transmitiu, contribuindo com o meu desenvolvimento acadêmico e pessoal. Obrigada por todo o incentivo e carinho.

Agradeço à Fundação de Amparo à Pesquisa do Estado de São Paulo (FAPESP), pelo apoio financeiro a mim concedido, por meio da outorga da bolsa de mestrado (Processo 05/50826-6).

Agradeço também ao Professor Dr. Michel M. Mahiques, pela cessão das amostras e das datações radiométricas para esta dissertação. Agradeço por toda a ajuda, pelos esclarecimentos de dúvidas pertinentes a esse material e por todas as relevantes considerações.

À mestre Simone S. Sonvesso, pelos dados abióticos aqui utilizados. Obrigada pela pronta colaboração e por todas as importantes informações.

Ao Professor Dr. Kenitiro Suguio, que me recebeu com generosidade e realizou a revisão deste trabalho. Agradeço-lhe, ainda, por todas as elucidações acerca das curvas de variação do nível do mar.

Ao Professor Dr. Thomas R. Fairchild, pela revisão do abstract e por toda a ajuda durante o meu mestrado.

Ao Professor Dr. André O.Sawakuchi pelas importantes ajuda e revisão e também pelas valiosas sugestões oferecidas da reinterpretação e retabulação dos dados sedimentológicos e colunas sedimentares dos testemunhos UB 1 e UB 3.

Ao Prof. Dr. Setembrino Petri, por todo o aprendizado e pela indispensável contribuição com material bibliográfico - livros, artigos, revistas - muitos dos quais utilizados nesta dissertação.

Aos funcionários do Instituto de Geociências (IGcUSP), que foram fundamentais durante todo o mestrado: Ana Paula e Magali, da Secretaria de PósGraduação; equipes dos laboratórios LABSED e LABMEV; funcionários da biblioteca e da portaria; equipes de xerox e da gráfica. Agradeço, ainda, aos funcionários da biblioteca do Instituto Oceanográfico (IOUSP). O meu trabalho não seria o mesmo sem essa grande equipe de apoio. 
Aos amigos do laboratório: Luciana, Priscilla, Valdemar, Silas, Rafaela, Maria Fernanda, Andreia e Sabrina, pelos bons momentos que passamos juntos.

Aos amigos de perto e de longe, pela dedicação e fidelidade que, durante todo esse tempo, foram essenciais.

Aos queridos Cristiane, Adilson, Arthur e Juliana, pela calorosa acolhida e pelo cuidado e carinho que nunca me deixaram faltar.

E finalmente agradeço a todos aqueles a quem recorri, nos momentos de necessidade. 


\section{Índice Geral}

Índice de Tabelas __ iii

Índice de Figuras ___ iv

Resumo _ vi

Abstract __ viii

CAPÍTULO 1: Introdução ___ 1

Trabalhos Anteriores Realizados na Área __ 3

CAPÍTULO 2: Objetivos e Justificativa __ 6

Objetivo Geral __ 6

Objetivos Específicos __ 6

Justificativa

CAPÍTULO 3: Área de Estudos___ 8

Contexto Geológico Regional ___ 8

Contexto Climatológico ___ 11

Contexto Oceanográfico _ 12

Descricão das Enseadas do Flamengo e da Fortaleza ___ 15

CAPÍTULO 4: Materiais e Métodos __ 20

Procedência das Amostras e dos Dados Abióticos __ 20

Laboratório de Micropaleontologia, IGc-USP _ 21

Laboratório de Microscopia Eletrônica de Varredura - IGcUSP _ 22

Tratamento de Dados __ 22

CAPÍTULO 5: Resultados _ 25

Testemunho UB1

Descrição Macroscópica e Análises Granulométricas __ 25

Análises Radiométricas $\left({ }^{14} \mathrm{C}\right) \_26$

Análise geoquímica __ 27

$\underline{\text { Testemunho UB3 }} 33$

Descrição Macroscópica e Análises Granulométricas ___ 33

Análises Radiométricas $\left({ }^{14} \mathrm{C}\right) \ldots 34$

Análise geoquímica __ 34

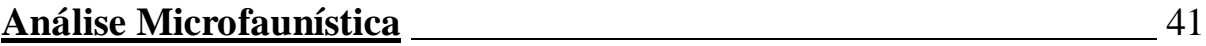


Testemunho UB1

Densidade, Riqueza e Composição Faunística 41

Principais Espécies Bioindicadoras e Microhabitats 45

Análise Morfométrica 48

Análise Tafonômica 48

Testemunho UB3 51

Densidade, Riqueza e Composição Faunística 51

Principais Espécies Bioindicadoras e Microhabitats 55

Análise Morfométrica 59

Análise Tafonômica 59

Correlação entre Dados Bióticos e Abióticos 63

Análise de CorrelaçãoCanônica (ACC) 65

CAPÍTULO 6: Discussão 69

Comparacão das Associacões de Foraminíferos Recentes

e Sub-Recentes das Enseadas do Flamengo e da Fortaleza 69

Composicões Faunísticas ao Longo dos Testemunhos UB1 e UB3 72

Análise Morfométrica ao Longo dos Testemunhos UB1 e UB3 75

Análise Tafonômica ao Longo dos Testemunhos UB1 e UB3 77

Correlacão Entre Dados Bióticos e Abióticos 79

Índice Ammonia-Elphidium e Modelo TROX 79 Análise de CorrelaçãoCanônica (ACC) dos Testemunhos UB1 e UB3 82

Evolucão Paleoambiental e suas Evidências Microfaunísticas 85

CAPÍTULO 7: Conclusões 94

CAPÍTULO 8: Referências Bibliográficas 98

Anexos 113 


\section{Índice de Tabelas}

Tabela 1 - Dados sedimentológicos do testemunho UB1

Tabela 2 - Dados geoquímicos do testemunho UB1

Tabela 3 - Dados sedimentológicos do testemunho UB3

Tabela 4 - Dados geoquímicos do testemunho UB3

Tabela 5 - Espécies de foraminíferos encontradas no testemunho UB1 em anexo

Tabela 6 - porcentagem das espécies de foraminíferos de testas hialinas e porcelanosas encontradas ao longo do testemunho UB1

Tabela 7 - Freqüência relativa de espécies de foraminíferos encontradas no testemunho UB1 em anexo

Tabela 8 - Espécies de foraminíferos encontradas no testemunho UB3 em anexo

Tabela 9 - porcentagem das espécies de foraminíferos de testas hialinas, porcelanosas e aglutinantes encontradas ao longo do testemunho UB3 45

Tabela 10 - Frequiência relativa de espécies de foraminíferos encontradas no testemunho UB1 em anexo

Tabela 11 - Tabela de autovalores dos testemunhos UB1 e UB3 66 


\section{Índice de Figuras}

Figura 1 - Modelo de variação do nível médio do mar nos últimos

7.000 anos A.P. 5

Figura 2 - Mapa geológico das Formações Quaternárias e Embasamento

Cristalino da costa sudeste brasileira 10

Figura 3 - Circulação geral da atmosfera 11

Figura 4 - Áreas fontes e principais trajetórias dos sistemas atmosféricos 12

Figura 5 - Circulação superficial do Atlântico Sul 13

Figura 6 - Massas de água que atingem a costa sudeste brasileira 13

Figura 7 - Área de estudo e localização dos testemunhos coletados UB1 e UB3 e do testemunho FLT1 de Duleba (1993) 19

Figura 8 - Sputter Coating Emitech K550 22

Figura 9 - Coluna sedimentar, estruturas sedimentares, componentes biogênicos, granulometria e datação radiométrica $\left({ }^{14} \mathrm{C}\right)$ do testemunho UB1 _ 29

Figura 10 - Coluna sedimentar e resultados granulométricos, geoquímicos e datação radiométrica $\left({ }^{14} \mathrm{C}\right)$ do testemunho UB1 30

Figura 11 - Coluna sedimentar, estruturas sedimentares, componentes biogênicos, granulometria e datação radiométrica $\left({ }^{14} \mathrm{C}\right)$ do testemunho UB3 _ 37

Figura 12 - Coluna sedimentar e resultados granulométricos, geoquímicos e datação radiométrica $\left({ }^{14} \mathrm{C}\right)$ do testemunho UB3 38

Figura 13 - Gráficos de densidade e riqueza das espécies de foraminíferos encontrados no testemunho UB1

Figura 14 - Gráficos de frequiência relativa dos principais gêneros e espécies do testemunho UB1 44

Figura 15 - Gráficos de espécies indicadoras das massas de água Água Costeira (AC), Água Central do Atlântico Sul (ACAS) e Água Tropical (AT), de Matéria Orgânica (M.O.), de oxigenação do meio e de microhabitat presentes ao longo do testemunho UB1 _ 47 
Figura 16 - Gráficos de tamanho, coloração e grau de fragmentação das testas de foraminíferos das amostras do testemunho UB1 50

Figura 17 - Gráficos de densidade e riqueza das espécies de foraminíferos encontrados no testemunho UB3 53

Figura 18 - Gráficos de frequiência relativa dos principais gêneros e espécies do testemunho UB3 54

Figura 19 - Gráficos de espécies indicadoras das massas de água Água Costeira (AC), Água Central do Atlântico Sul (ACAS) e Água Tropical (AT), de Matéria Orgânica (M.O.), de oxigenação do meio e de microhabitat presentes ao longo do testemunho UB3 _ 58

Figura 20 - Gráficos de tamanho, coloração e grau de fragmentação das testas de foraminíferos das amostras do testemunho UB3 62

Figura 21 - Gráficos do Índice A-E (Smmonia-Elphidium) obtidos para para os testemunhos UB1 e UB3 64

Figura 22 - Biplot de amostras e variáveis ambientais para os testemunhos UB1 e UB3 67

Figura 23 - Biplot de espécies e variáveis ambientais para os Testemunhos UB1 e UB3 68 


\section{Resumo}

A partir do padrão de distribuição das associações de foraminíferos ao longo de dois testemunhos e da sua correlação com características abióticas do sedimento, detectaram-se variações ambientais holocênicas ocorridas em dois embaiamentos marinhos rasos: as enseadas do Flamengo (Testemunho UB1) e da Fortaleza (Testemunho UB3), em Ubatuba, SP. Posteriormente, correlações foram estabelecidas entre as mudanças da composição faunística e curvas de variação do nível do mar existentes na literatura. O testemunho UB1 possui $222 \mathrm{~cm}$ de profundidade e foi coletado no Saco da Ribeira sob lâmina de água de $3,10 \mathrm{~m}$. É constituído predominantemente por sedimentos sílticos que contêm fragmentos vegetais e biodetríticos. Camadas arenosas são encontradas em sua base, datada em $7290 \pm 40$ anos A.P., e à profundidade compreendida entre 32 e $12 \mathrm{~cm}$. O testemunho UB3 tem $342 \mathrm{~cm}$ de profundidade e foi coletado na Praia do Lázaro sob lâmina de água de 3,80 m. Seus sedimentos são predominantemente sílticos, contendo fragmentos vegetais, fragmentos vegetais oxidados e fragmentos biodetríticos. Seqüências arenosas e arenosiltosas são encontradas em sua base, datada em $7.530 \pm 40$ anos A.P., e entre 32 e 12 $\mathrm{cm}$ de profundidade. Foram identificados 76 espécies e 40 gêneros de foraminíferos bentônicos e uma espécie de foraminífero planctônico nas 58 amostras analisadas, a cada $10 \mathrm{~cm}$, ao longo dos dois testemunhos (23 amostras em UB1 e $35 \mathrm{em} \mathrm{UB3}$ ). As associações observadas são típicas de ambiente marinho normal, de plataforma interna, com tendência redutora. Foraminíferos de testas hialinas predominam sobre foraminíferos de testas porcelanosas. Somente uma espécie de testa aglutinante foi encontrada em cinco amostras dispersas ao longo do testemunho UB3. As espécies

bioindicadoras indicam ambientes com predominância da massa de Água Costeira, com energia de fundo moderada, alta acumulação de matéria orgânica e baixas concentrações de oxigênio, tanto para a Praia do Lázaro quanto para o Saco da Ribeira, nos últimos 7.500 anos A.P. Evidenciam, também, que a circulação de fundo no Saco da Ribeira se tornou cada vez mais restrita, enquanto na Praia do Lázaro a circulação hidrodinâmica não sofreu forte alteração. Os dados tafonômicos indicam que não houve processos post mortem capazes de alterar por completo as associações de foraminíferos analisadas ao longo de ambos os testemunhos. Todas as evidências microfaunísticas sugerem que 
houve, pelo menos, duas fases distintas de comportamento marinho para as duas enseadas ao longo dos últimos 7.500 anos A.P.: uma primeira, transgressiva, que teria durado até a, aproximadamente, 5.100 anos A.P., durante a qual as enseadas se encontravam conectadas; e outra de caráter geral regressivo, que se estendeu até a, pelo menos, $32 \mathrm{~cm}$ de profundidade em ambos os testemunhos, durante a qual teria surgido o Tômbolo do Saco da Ribeira, que passou a impedir a circulação entre a Praia do Lázaro e o Saco da Ribeira. 


\begin{abstract}
Variations in Holocene environments in the marine bays of Flamengo and Fortaleza at Ubatuba, State of São Paulo, southeast Brazil, were detected in cores UB1 and $\mathrm{UB} 3$, respectively, on the basis of the distribution pattern of foraminiferal associations and their correlation with abiotic characteristics of the sediments. Correlations were then established between changes in faunistic composition and existing sea-level variation curves. The UB1 Core measures $222 \mathrm{~cm}$ and was collected at Saco da Ribeira at a water depth of $3.1 \mathrm{~m}$. This core is predominantly made up of silty sediments with biodetritus and plant fragments. Arenaceous layers at its base were dated by radiocarbon at $7.290 \pm 40$ years B.P., and also occur between 32 and $12 \mathrm{~cm}$ depth. The UB3 Core measures $342 \mathrm{~cm}$ and was collected at Praia do Lázaro at a water depth of $3.8 \mathrm{~m}$. It is predominantly silty and contains fragments of plants, oxidized plants and biodetritus. Sandy and muddy sand layers were encountered at its base, with a radiocarbon age of $7.530 \pm 40$ years B.P., and between 32 and $12 \mathrm{~cm}$ of depth. 76 species and 40 genera of benthic foraminifera and one species of planktonic foraminifera were identified in the cores. The observed associations are typical of normal marine, inner shelf environments, with low oxygen. Hyaline foraminifera predominate over porcelaneous species. Only one species of agglutinated test was found within the five samples of the UB3 Core. The bioindicator species indicate environments with a predominance of Coastal Water (CA), moderate hydrodynamic energy, high organic matter accumulation and low oxygen concentrations for both Praia do Lázaro and Saco da Ribeira since early on. They also show that the deep marine circulation in Saco da Ribeira has become ever more restricted from approximately 7.500 years B.P. until the present, while in Praia do Lázaro, deep circulation has not suffered any strong alteration. Taphonomical data suggest that there is no post mortem process capable of completely modifying the foraminiferal associations analyzed in the cores. All the microfaunistic evidence suggests at least two distinct phases of marine behavior for the two bays over the past 7.500 years: a former transgressive phase, that lasted until approximately 5.100 years B.P., during which the bays were connected; and a latter generally regressive phase, that would have extended itself until, at least, the depth of $32 \mathrm{~cm}$ in both cores, during which the appearance of the Tômbolo do Saco da Ribeira would have begun to hinder circulation between Praia do Lázaro and Saco da Ribeira.
\end{abstract}




\section{CAPÍTULO 1: Introdução}

Foraminíferos são microrganismos protozoários rizópodes que surgiram a partir de um ancestral comum denominado Cercozoa (Pawlowski et al., 2003). Pertencentes ao Reino Protista, Filo Granuloreticulosa, Classe Foraminífera (Sen Gupta, 1999), esses microorganismos são importantes bioindicadores de estudos ambientais e paleoambientais, paleoceanográficos, oceanográficos, ecológicos, paleoecológicos, geológicos, estratigráficos, biológicos e econômicos, pois são, em sua maioria, estenobióticos (Boltovskoy et al., 1991), ou seja, sensíveis às variações ambientais de seus habitats, tais como temperatura, profundidade, salinidade, $\mathrm{pH}$, tipo de substrato, oxigênio dissolvido e nutrientes.

Além disso, possuem ampla distribuição geográfica (horizontal) e batimétrica (vertical) nos oceanos, algumas espécies possuem distribuição estratigráfica restrita (Duleba, 1993), são abundantes, pequenos, têm baixo poder de locomoção, possuem características ecológicas e biológicas conhecidas, são fáceis de coletar e armazenar, permitindo análises a baixo custo e de fácil identificação taxonômica (Boltovskoy \& Wright, 1976; Loeblich \& Tappan, 1988).

Todas essas características possibilitam que os foraminíferos sejam aplicados de diversas formas nesses estudos. Por exemplo, o surgimento de espécies ou de associações distintas permite a realização de estudos bioestratigráficos ou biogeográficos (Boltovskoy, 1964; Boltvoskoy \& Wright, 1976; Wan et al., 2005), a presença de determinadas espécies ou de testas deformadas pode significar a ocorrência de impactos ambientais no meio (Sharifi et al., 1991; Reinhardt et al., 1994; Scott et al., 1995; Williams, 1995; Hallock et al., 1995; Williams et al., 1997; Yanko et al., 1999; Debenay et al., 2001; Teodoro, 2006), enquanto análises isotópicas das testas permitem obter dados significativos das massas de água pretéritas, como, por exemplo, a análise isotópica de $\delta^{13} \mathrm{C}$, que possibilita o conhecimento acerca da paleoprodutividade da área (Mackensen et al., 2000; Jian et al., 2001; Yamane, 2003; Hess \& Kuhnt, 2005; Eberwein \& Mackensen, 2007; Zhang et al., 2007).

Foraminíferos também são utilizados como importantes ferramentas em estudos sobre a variação relativa do nível do mar, pois apresentam respostas singulares a essas variações, que são facilmente identificadas por meio de estudos realizados sobre as 
características de suas testas e nas modificações que ocorrem em suas populações. A ocorrência ou o desaparecimento de espécies bentônicas indicadoras de diferentes tipos de massas de água e correntes marinhas, de oxigenação do meio ou da quantidade de matéria orgânica disponível, determina as características ambientais do meio em que vivem ou viveram (Duleba et al., 2005), enquanto o estudo de foraminíferos planctônicos pode indicar a ocorrência de distintas profundidades da coluna de água, variações na temperatura das águas oceânicas, diferentes latitudes ou se existem áreas de ressurgência na região que habitam ou habitaram (Murray, 1991).

Todas essas informações sugerem mudanças no padrão de circulação oceânica, identificação de períodos de isolamento marinho ou de influência acentuada de águas continentais em ambientes costeiros, possibilitando assim a elaboração de curvas de variação do nível do mar (Schnitker, 1974; Sturrock \& Murray, 1981; Wrightman et al., 1994; Lea et al., 1995; Longyin et al., 2000; Faul et al., 2000; Rathburn et al., 2000; Gebhardt et al., 2004; Giraudeau et al., 2004).

Variações relativas do nível do mar ocorrem como respostas dos processos de eustasia (variações reais dos níveis oceânicos a nível global) e dos processos isostáticos e/ou tectônicos dos terrenos emersos adjacentes (Martin et al., 1986).

Dessa forma, o nível marinho em determinado local da costa é o produto de interações complexas entre os níveis das superfícies oceânicas e das terras emersas adjacentes (Suguio et al., 2005), com efeitos que ocorrem a nível global quando as mudanças que os geram são maiores (variações dos volumes das águas oceânicas e oscilações das bacias oceânicas) e em escala regional quando as mudanças que os geram atingem áreas menores (geóides ou continentes). Por esse motivo, existem muitas inconsistências que são completamente cabíveis entre reconstituições de paleoníveis marinhos de mesmas idades em diferentes locais da superfície da Terra (Suguio et al., 2005), já que áreas litorâneas distintas podem ou não estar sofrendo processos tectônicos desiguais e/ou variações regionais do nível do mar ao mesmo tempo.

Para que se possam reconstituir antigas posições de níveis marinhos, é necessário que o setor costeiro escolhido para o estudo seja geologicamente homogêneo e tenha comportamento tectônico bem conhecido. Então se deve definir algum indicador espaço-temporal dessas antigas posições (testemunho ou evidência) que tenha bem conhecidas sua altitude de deposição e o tempo em que essa deposição ocorreu (através 
da realização de datação absoluta, geralmente obtida por meio de radioisotopia). Uma vez que o indicador escolhido tenha estabelecidas essas características, ele fornece a posição relativa do paleonível do mar ou da paleolinha de costa e, se for obtido número suficiente de antigas posições ocupadas pelo mar em determinado setor costeiro por intervalo de tempo definido, pode-se delinear a curva de variação do nível do mar do lugar analisado (Suguio et al., 2005).

Além dos foraminíferos, outros indicadores utilizados para a realização de estudos de reconstituição de paleoníveis marinhos e/ou oceânicos são os fatores geomorfológicos, características sedimentares, sedimentológicas e biológicas de sequiências deposicionais obtidas através de testemunhagem, rochas praiais (beachrocks), rupturas de pendentes de fundos oceânicos, terraços de construção ou de abrasão marinhos, indicadores pré-históricos (sambaquis) e outros indicadores biológicos, tais como vermetídeos (moluscos gastrópodes), ostras, corais, entre outros.

Assim, o estudo dos foraminíferos em conjunto com a observação de outros fatores abióticos pertencentes a um dado indicador torna possível a identificação de mudanças ocorridas na interface sedimento-água (foraminíferos bentônicos) e na coluna de água (foraminíferos planctônicos) de determinado local. As características do meio fornecidas pelas associações de foraminíferos permitem, pois, de forma direta ou indireta, determinar as modificações sofridas nos ambientes marinhos no decorrer do tempo geológico, auxiliando a interpretação paleoceanográfica não apenas no que diz respeito às alterações de nível do mar, mas também sobre os demais parâmetros ambientais.

\section{Trabalhos Anteriores Realizados na Área}

Este trabalho concentra-se, zoogeograficamente, na denominada Subprovíncia Sul Brasileira, que pertence à Província das Índias Ocidentais (Boltovskoy, 1964). Ela se estende do paralelo $23^{\circ} \mathrm{S}$ ao paralelo $33^{\circ} \mathrm{S}$ (Tinoco, 1975), e corresponde a zona de transição em que ocorrem águas quentes provenientes da Corrente do Brasil e águas frias, vindas de Sul, apresentando associação de foraminíferos de espécies típicas de águas quentes e de águas temperadas (Boltovskoy, 1964). 
Vários trabalhos têm sido realizados nessa Subprovíncia e, mais especificamente, na região de Ubatuba. Esses trabalhos têm caráter ambiental e paleoambiental e se utilizam do estudo das associações de foraminíferos encontrados nessa região. Eles levam em consideração a resposta dessas associações às mudanças ambientais ocorridas no meio através da observação de variações nessas associações e das diferenciações morfométricas, morfológicas e/ou estruturais de suas testas. Levam também em consideração os fatos ocorridos no período post mortem dos foraminíferos, que podem alterar a constituição dessas associações, levando a conclusões errôneas. Dentre eles, citam-se os trabalhos de Sanches (1992), Eichler (1982, 1989), Furtado \& Eichler (1987), Furtado et al. (1987, 1988), Eichler \& Furtado (1989), Duleba (1997), Duleba et al. (1997, 1999, 2003).

$\mathrm{Na}$ Enseada do Flamengo, trabalhos mais recentes estudaram as características ambientais através das associações de foraminíferos recentes, dentre os quais se citam os estudos de Lançone et al. (2005), Fonseca (2005), Duleba et al. (2005), bem como realizaram a sua reconstituição paleoambiental (Duleba, 1993; Silva et al. 2006, 2007a).

Ao contrário da Enseada do Flamengo, a Enseada da Fortaleza não apresenta número tão extenso de trabalhos. Dentre os existentes, citam-se aqueles que se utilizaram das associações recentes de foraminíferos para descrever as características ambientais atuais dessa enseada (Duleba et al., 2005; Filippos, 2006) e os que estudaram as associações de foraminíferos de testemunhos para melhor compreender a evolução paleoambiental dessa região (Silva et al., 2006, 2007b).

No tocante aos estudos acerca da reconstituição de curvas do nível do mar, há vários estudos realizados no trecho da costa brasileira que envolve a região de Ubatuba (costa Sudeste), apesar da maior parte desses estudos ter sido realizada na costa Sul do Brasil. Esses trabalhos levam em consideração a Transgressão Santos, última transgressão ocorrida nesses setores da costa brasileira.

Esses estudos se concentram principalmente nas mudanças de nível marinho que ocorreram durante os últimos 7.000 anos, sendo que o conhecimento acerca das variações do nível do mar é amplo para os últimos 6.500 anos, que possui diversos indicadores geológicos, biológicos e pré-históricos reconhecidos e estudados. Curvas de paleoníveis marinhos completas ou parciais têm sido elaboradas para os últimos 7.000 anos da Transgressão Santos com base em dados obtidos a partir de terraços marinhos 
holocênicos e outros indicadores para vários trechos da costa brasileira. Essas curvas podem ser sumarizadas em modelo (Figura 1) apresentado por Suguio \& Tessler (1984, apud Suguio et al., 2005).

Além desses trabalhos, citam-se os trabalhos de Suguio et al. (1985), Tomazelli (1990), Mesquita (1994), Angulo \& Suguio (1995), Angulo \& Lessa (1997), Martin et al. (1998), Tomazelli et al. (1998) e Ybert et al. (2003), Angulo et al. (2005), Angulo et al. (2006).

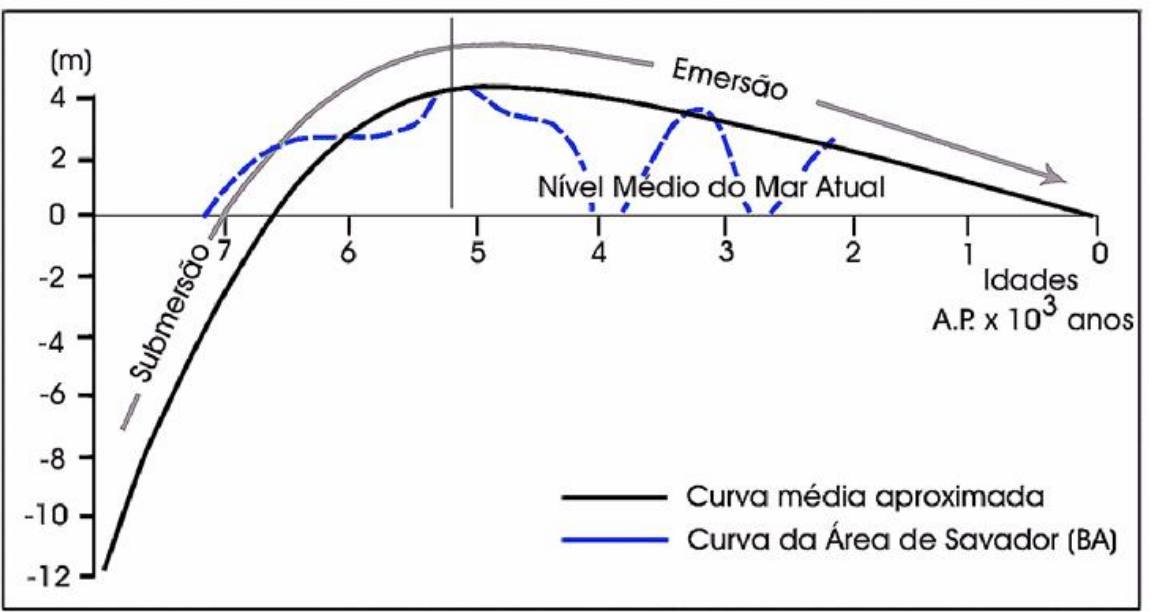

Figura 1: Modelo de variação do nível médio do mar nos últimos 7.000 anos A.P. Extraído de Suguio et al., 2005. 


\section{CAPÍTULO 2: Objetivos e Justificativa}

\section{Objetivo Geral}

Realizar a reconstituição paleoambiental, das enseadas do Flamengo e da Fortaleza, Ubatuba, SP, ao longo dos últimos 7.500 anos A.P. ${ }^{1}$, a partir da distribuição dos foraminíferos e de dados abióticos, obtidos em dois testemunhos de sondagem, UB1 (Enseada do Flamengo) e UB3 (Enseada da Fortaleza).

\section{Objetivos Específicos}

> Analisar e detalhar as principais características composicionais, morfológicas, tafonômicas e morfométricas das associações de foraminíferos presentes ao longo dos testemunhos UB1 e UB3, correlacionando-as, posteriormente, com dados granulométricos, geoquímicos e isotópicos de seus sedimentos.

$>$ Confrontar os diagnósticos paleoambientais, obtidos pelos dados microfaunísticos e abióticos, com as curvas de variação do nível do mar, existentes na literatura.

> Comparar as hipóteses de variação ambiental para a região em estudo, adquiridas a partir dos dados microfaunísticos e abióticos dos testemunhos, com aquelas propostas nos trabalhos de Duleba (1993) e Duleba et al. (1999) para esta mesma área.

\section{Justificativa}

A região das enseadas do Flamengo e da Fortaleza (Ubatuba, litoral norte do estado de São Paulo), concentra estudos ambientais que utilizam foraminíferos recentes como bioindicadores (por exemplo, Sanches, 1992; Duleba et al., 2005; Fonseca, 2005; Lançone et al., 2005, Filippos, 2006). Esses estudos caracterizam tais enseadas quanto às mudanças ambientais que nelas ocorrem sazonalmente (verão/inverno), e descrevem espacialmente as diferenças que existem entre as enseadas ou dentro de uma única

\footnotetext{
${ }^{1}$ A.P. $=$ antes do presente. Considera-se como "presente" o ano de 1950 para as datações ${ }^{14} \mathrm{C}$ convencionais.
} 
enseada. Entretanto, eles não englobam mudanças ocorridas ao longo do tempo geológico.

Trabalhos que englobam variações dos parâmetros paleoecológicos ao longo do Neógeno foram realizados na Enseada do Flamengo (Duleba, 1993; Duleba et al., 1997, 1999, 2003). Não existem, entretanto, trabalhos semelhantes para a Enseada da Fortaleza.

Dessa forma, o presente trabalho se torna importante, pois, por meio da integração de dados granulométricos, geoquímicos, isotópicos e microfaunísticos, mudanças paleoambientais, ocorridas ao longo dos últimos 7.500 anos, poderão ser detectadas, contribuindo, portanto, para o conhecimento da evolução sedimentar da área, assim como das oscilações do nível do mar durante o Neógeno.

Além dessa importância de natureza científico-acadêmica, esse trabalho também é importante para fornecer subsídios para o conhecimento a respeito dessa região litorânea, visto que estas áreas estão sofrendo ocupação humana cada vez maior, com o intuito de prever, impedir ou amenizar futuras situações de risco à comunidade local, tais como de erosão costeira e de aumento do nível oceânico, entre outros. 


\section{CAPÍTULO 3: Área de Estudo}

\section{Contexto Geológico Regional}

A região costeira do estado de São Paulo se integra à região de dobramentos do sudeste que, por sua vez, está inclusa no Escudo Atlântico da Plataforma SulAmericana.

Ela faz parte da região geomorfológica brasileira conhecida como Plataforma Continental Sudeste (PCSE), parte da costa brasileira compreendida entre Cabo Frio e Cabo de Santa Marta. A PCSE tem forma aproximada de lua crescente, com comprimento total aproximado de $1.000 \mathrm{~km}$ e larguras entre 50 e $230 \mathrm{~km}$. Apresenta topografia suave, com as isóbatas paralelas à linha de costa. Nessa região, a profundidade da quebra da plataforma continental varia de 120 a $180 \mathrm{~m}$ e há influência de fluxos relativamente intensos, típicos das correntes de contorno oeste (Aristeu, 1998). A linha de costa tem orientação geral NE-SW, com exceção das regiões situadas imediatamente ao Sul de Cabo Frio $\left(23^{\circ} \mathrm{C}\right)$, onde a costa tem orientação N-S.

As rochas que formam a PCSE datam de 2.2 B.a. (idade Transamazônica) ou são ainda mais antigas e foram retrabalhadas (remobilizadas, migmatizadas e granitizadas) durante o Ciclo Brasiliano (600 M.a.) (Almeida, 1976). Durante a reativação tectonomagmática da Plataforma Sul-Americana (Brasileira), que ocorreu a partir do Jurássico (150 M.a.), o conjunto de rochas original foi cortado por intrusões de rochas básicas e alcalinas e parcialmente recoberto por sedimentos quaternários (Figura 2).

Essa reativação tectono-magmática ocorreu durante a abertura do Oceano Atlântico Sul (129 M.a.), quando os continentes da América do Sul e da África se dissociaram. Com a separação, a costa sudeste do Brasil se formou, evoluindo a partir daí até atingir sua conformação atual. As movimentações continentais geraram falhas normais e profundas que deram origem às bacias sedimentares costeiras brasileiras.

Almeida (1976) interpretou a evolução da região costeira brasileira no estado de São Paulo, chegando à conclusão de que a Serra do Mar se elevou no Cretáceo Superior. Seguindo-se à elevação, houve duas fases de atividade tectônica, uma no Paleógeno, durante o Oligoceno, responsável pela formação do rifte de Guanabara e pelos falhamentos do graben do Paraíba; e outra durante o Plioceno, que instalou a Bacia de 
São Paulo, ampliou as taxas de subsidência das bacias de Taubaté e Resende e se caracterizou por uma elevação epirogênica generalizada (Almeida, 1976; Rodrigues, 2006).

Localmente, a região de Ubatuba caracteriza-se por planícies costeiras reduzidas e descontínuas, separadas por afloramentos de rochas do embasamento cristalino PréCambriano, com invasão do mar. Essas planícies são caracterizadas como planícies do tipo Boiçucanga (Suguio \& Martin, apud Mahiques, 1992), as quais apresentam sedimentos marinhos em contato direto com sedimentos continentais do sopé da serra, sem a presença de sedimentos lagunares (Suguio \& Martin, apud Mahiques, 1992). As enseadas do Flamengo e da Fortaleza formaram-se inseridas nesse contexto.

Ao longo de todo o Neógeno, essa região tem se mostrado geologicamente ativa. Vários foram os eventos geológicos que ocorreram e que foram modificando a sua configuração, até que ela atingisse seu perfil atual. Dois eventos de transgressão marinha (Transgressão Cananéia, 120.000 anos A.P.; e Transgressão Santos, 5.100 anos A.P.) foram registrados por Suguio \& Martin (1976). Ponçano (1985) demonstrou a importância do último fenômeno glácio-eustático de rebaixamento do nível do mar (18.000 anos A.P.) para a compreensão dos processos atuais nas regiões costeiras; e alguns autores destacaram, pelo menos, quatro eventos geológicos principais para a região durante o Neógeno Superior, a saber (Rodrigues, 2006):

- Máximo regressivo do Pleistoceno Superior (18.000 anos A.P.);

- Mudanças climáticas globais que levaram à estabilização do nível do mar (10.000 anos A.P.);

- Máximo da transgressão holocênica (5.100 anos A.P.);

- Estabilização do nível do mar em valores próximos ao atual (últimos 2.500 anos A.P.).

Almeida (1976) definiu a região litorânea paulista como a área do estado drenada para o oceano e a denominou Província Costeira. Segundo Ponçano et al. (1981), a Província Costeira se subdivide em Serrania Costeira (Serra do Mar), representada por relevo do tipo escarpas abruptas e festonadas com declividades acima de $30 \%$, que exibem espigões que avançam para as baixadas; alcançam altitudes de 100 $m$ e têm drenagens de padrão subparalelo a dendrítico de alta densidade e comportamento bidirecional; e Baixada Litorânea (Planícies Costeiras), que é formada 
por terrenos baixos e próximos ao nível atual do mar, possui baixa densidade de drenagem e é composta por sedimentos marinhos e continentais quaternários (Mahiques, 1995).

É na Baixada Litorânea que se encontram as enseadas do litoral norte do estado de São Paulo, entre as quais estão as enseadas do Flamengo e da Fortaleza, estudadas nessa dissertação. Devido às suas configurações, essas enseadas apresentam características de semi-confinamento, o que faz com que os processos de troca de sedimentos (principalmente sedimentos terrígenos) e água entre a região costeira e a plataforma interna sejam restritas (Mahiques, 1995).

Ao longo da costa norte do estado de São Paulo, a área da plataforma continental apresenta tipos diferentes de sedimentos, com predominância de areias finas a muito finas. Nas porções externas às enseadas, a presença de feições de fundo oceânica geradas por condições dinâmicas de maior energia permite a ocorrência de sedimentos mais grossos e melhor selecionados. Essas condições de maior energia deposicional são devidas a processos hidrodinâmicos que incidem sobre a área, vindos de sul-sudeste. (Rodrigues et al., 2002). Provavelmente, essas ocorrências estão ligadas ao retrabalhamento de sedimentos relíquias, que se teriam concentrado nessas feições de fundo, o que explicaria a presença desse tipo de sedimento nessa região, uma vez que a mesma não apresenta fontes de sedimentos grossos (Rodrigues et al. 2002).

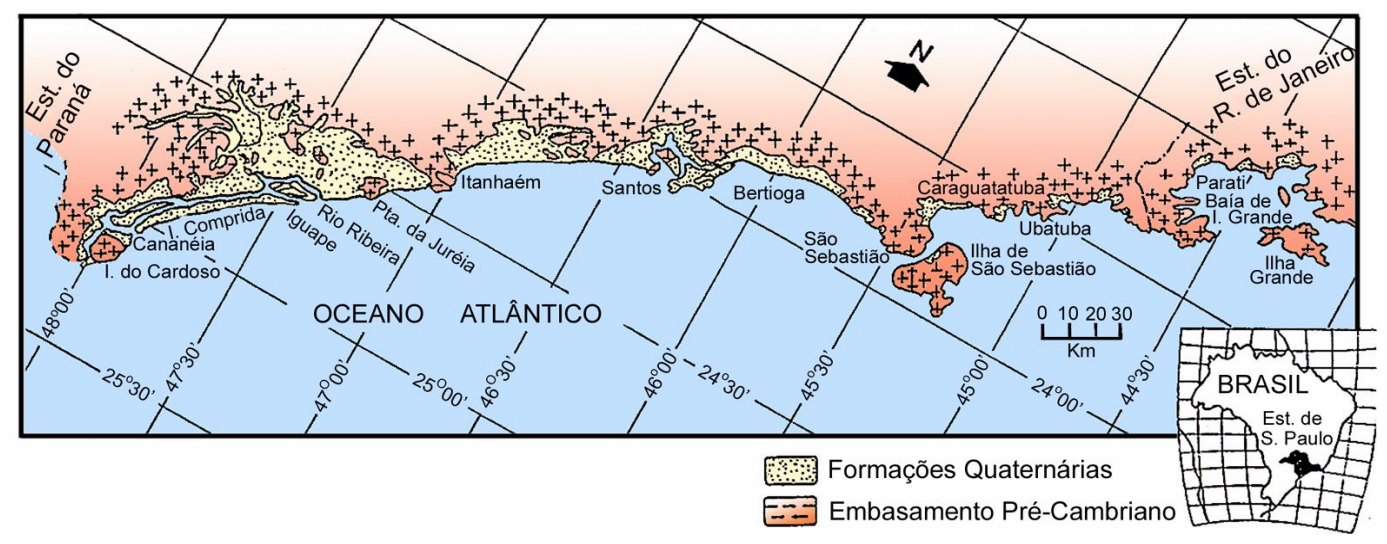

Figura 2: Mapa geológico das Formações Quaternárias e Embasamento Cristalino da costa sudeste brasileira. Extraído de Suguio \& Martin (1978). 


\section{Contexto Climatológico}

São dois os sistemas de massas de ar predominantes na região da plataforma continental sudeste brasileira: o Anticiclone Tropical Atlântico (ATA) e os Anticiclones Polares Migratórios (APM) (Figuras 3 e 4). Esses dois sistemas condicionam a circulação atmosférica da região e, com isso, controlam o sistema de ondas que são geradas no Atlântico Sul e se propagam para o litoral paulista (Rodrigues, 2006).

O ATA encontra-se a leste da costa brasileira e gera ventos anti-horários, chamados Alísios, que entre $10^{\circ}$ e $40^{\circ}$ de latitude sul tomam direção NE-NW. Eles formam sistemas de ondas que atingem a linha de costa de direção geral NE-SW, ocasionando a geração de deriva litorânea para SW. Esses ventos favorecem as temperaturas elevadas e a estabilidade do tempo (Rodrigues, 2006).

Já os APM formam frentes polares que se deslocam frontalmente à costa, modificando a situação climática gerada pelo ATA. Elas provocam frentes frias que modificam a direção dos ventos predominantes na região, os quais passam a vir do quadrante sul, com rotação horária. Essa situação condiciona incidência de trens de ondas de SW e SE que, por sua vez, formam correntes de deriva litorânea que percorrem a costa no rumo NE. Os APM também geram intensas precipitações pluviométricas (Rodrigues, 2006).

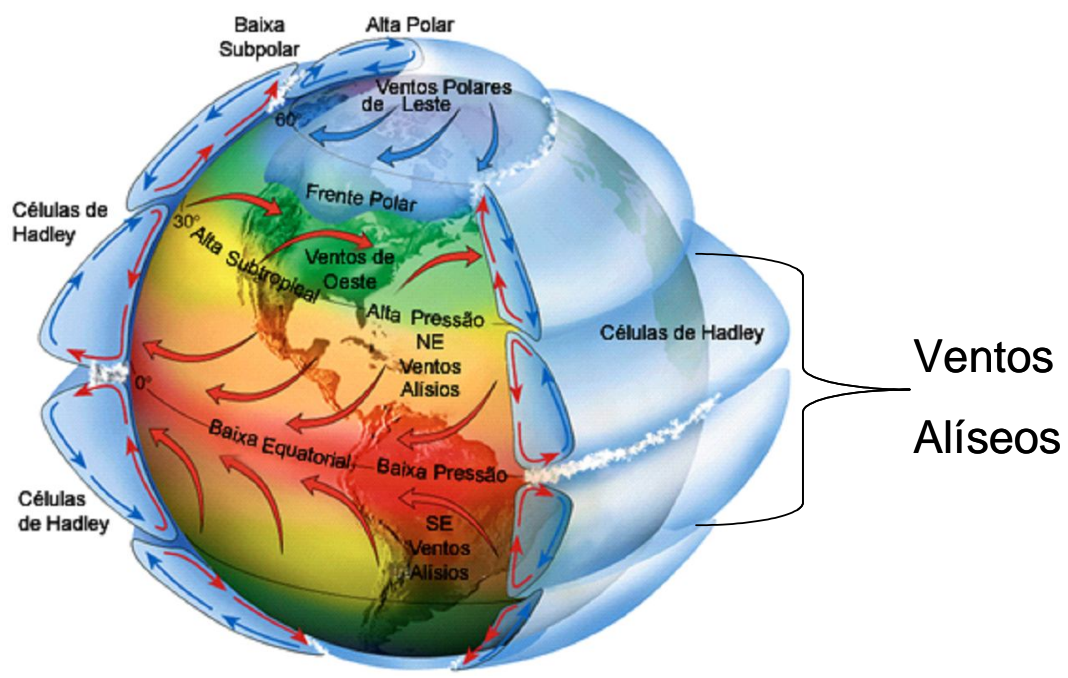

Figura 3: Circulação geral da atmosfera. Extraída de Sentelhas \& Angelocci, notas da aula LCE 360 Meteorologia Agrícola (2007). 

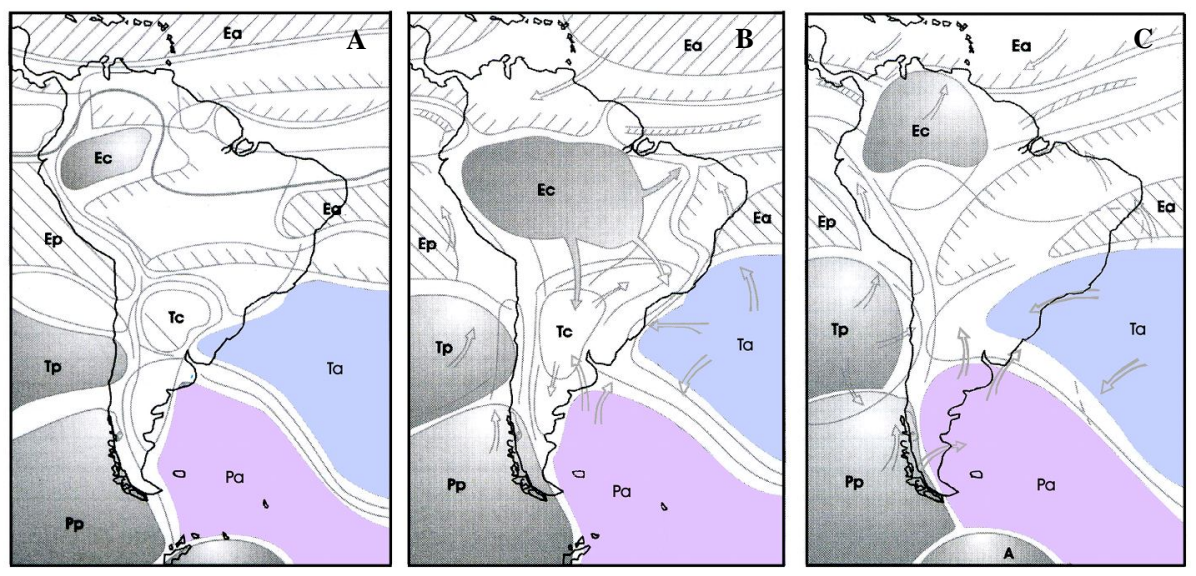

Figura 4: Áreas fontes e principais trajetórias dos sistemas atmosféricos. Coloridas, as principais massas de ar que atuam na região de Ubatuba. Pa: Massa Polar Atlântica (Anticiclone Polar Migratório). Ta: Massa Tropical Atlântica (Anticiclone Tropical Atlântico). Ea: Massa Equatorial Atlântica. Ec: Massa Equatorial Continental. Tc: Massa Tropical Continental. Ep: Massa Equatorial Pacífica. Tp: Massa Tropical Pacífica. Pp: Massa Polar Pacífica. A- posição média anual. B- situação típica de verão. C- situação de inverno. Extraída de Monteiro, 1976; Boin, 2000 (apud Neto \& Nery, 2005).

\section{Contexto Oceanográfico}

A margem continental brasileira da região de Ubatuba é banhada por águas que formam a Corrente do Brasil (CB), atuante da plataforma interna até porções oceânicas mais afastadas da costa e a Água Costeira (AC), que banha a região costeira dessa área. Estudos prévios de alguns autores (Matsuura, 1986; Castro Filho et al., 1987) demonstraram que os padrões de distribuição dessas massas de água que ocorrem durante o verão e durante o inverno são distintos.

A CB é uma corrente oceanográfica de contorno oeste, caracterizada por fluxos intensos, estreitos e bem definidos que está associada ao Giro Subtropical do Atlântico Sul. Ela se origina ao sul de $10^{\circ} \mathrm{S}$, onde o ramo mais ao sul da Corrente Sul Equatorial (CSE) se bifurca, formando, além da CB, a Corrente do Norte do Brasil (CNB) (Silveira et al., 2000) (Figura 5).

A partir daí a CB flui para o Sul, bordejando o continente sul-americano até alcançar a região da Convergência Subtropical (33-38 $\mathrm{S}$ ) quando conflui com a Corrente das Malvinas, separando-se da costa (Silveira et al., 2000). 


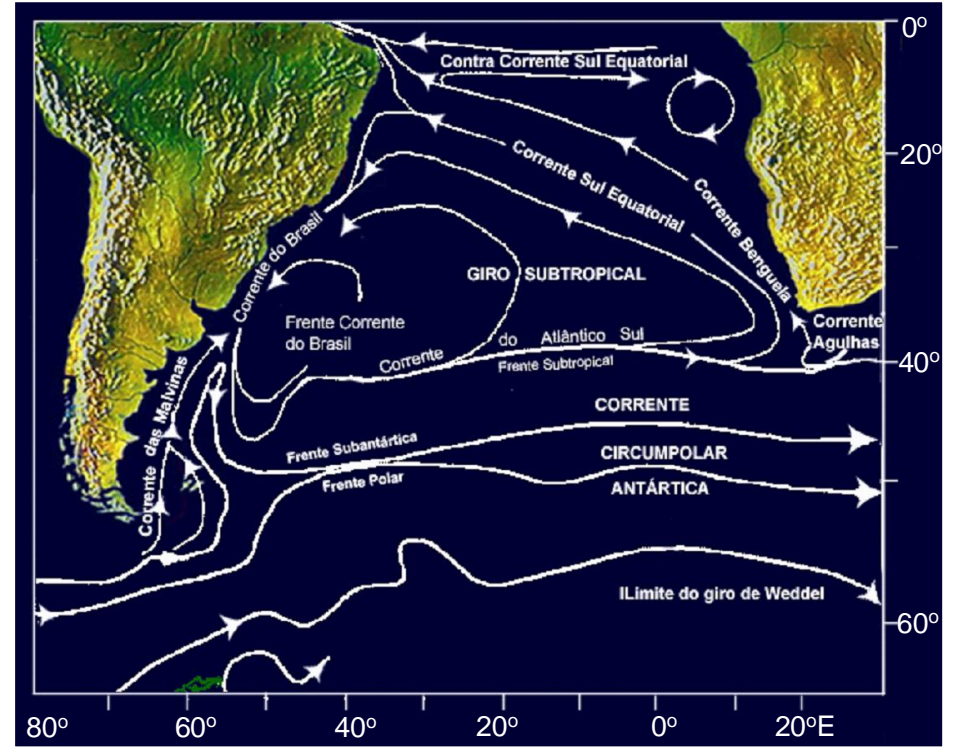

Figura 5: Circulação superficial do Atlântico Sul. Modificado de Peterson \& Stramma, 1991.

Na região da Plataforma Interna, a CB compõe-se pelas massas de água que alcançam menores profundidades: a Água Tropical (AT) e a Água Central do Atlântico Sul (ACAS). Além dessas, as outras massas de água que formam a CB são a Água Intermediária Antártica (AIA); a Água Circumpolar Superior (ACS) e a Água Profunda do Atlântico Norte (APAN) (Figura 6).

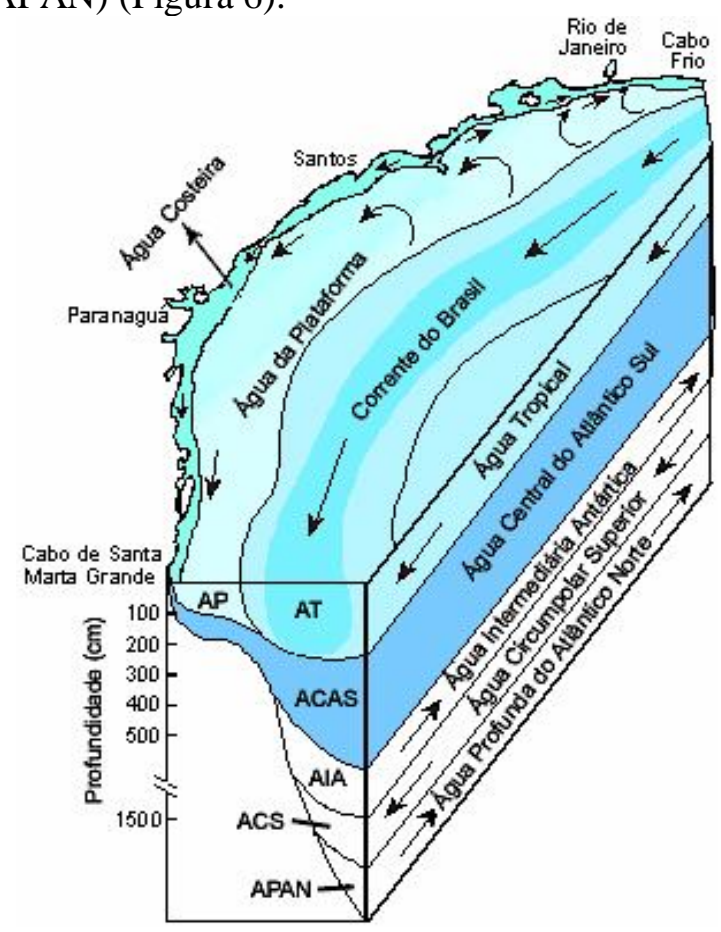

Figura 6: Massas de água que atingem a costa sudeste brasileira. Modificado de www.google.com.br 
A AT é uma massa de água quente e salina $\left(\mathrm{T} \approx 25^{\circ} \mathrm{C}\right.$; salinidade $\left.\approx 37,1\right)$ que ocupa as porções superiores do Atlântico Sul Tropical. Ela se forma devido à intensa radiação e excesso de evaporação em relação à precipitação, que são características nessa parte do Oceano Atlântico (Silveira et al., 2000; Mahiques et al.; 2002).

A ACAS flui na região da picnoclina, possuindo temperaturas em torno de $14^{\circ} \mathrm{C}$ e salinidades em torno de 35,5. Apesar da localização exata de seu padrão de fluxo ser incerta, existe um consenso na literatura de que a ACAS flui para o Sul ao largo da costa brasileira a partir do Cabo de São Tomé $\left(22^{\circ} \mathrm{S}\right)$. Ela se forma por afundamento das águas na região da Convergência Subtropical e então sofre espalhamento ao longo da superfície de densidade adequada a seu ajustamento hidrostático (Silveira et al., 2000; Mahiques et al., 2002).

No litoral paulista, há penetração da ACAS, mais densa, sobre a plataforma continental interna durante o verão (Silveira et al, 2000). Nessa época, a ACAS movimenta-se rumo à costa junto ao fundo, ao mesmo tempo em que as águas costeiras, menos densas, são deslocadas rumo ao oceano. É apenas nessa época que se observa a mistura vertical entre a ACAS e a AC nas proximidades da costa e, durante esse período, a influência da $\mathrm{AC}$ no fundo oceânico é mínima. Nessa época, também, ocorre a estação chuvosa no sudeste brasileiro, o que contribui para o aumento do aporte de sedimentos terrígenos nas águas costeiras. Assim, a AC transporta esses sedimentos em suspensão para porções mais profundas da plataforma (Mahiques et al., 1999). Ao mesmo tempo, a entrada da ACAS na plataforma interna gera áreas de ressurgência em regiões rasas, provendo nutrientes às águas pobres dessa área oceânica, contribuindo para o incremento da produtividade local (Silveira et al., 2000).

Após o verão, há o recuo da ACAS e a AT volta a ter maior influência nos processos oceânicos da plataforma interna (Silveira et al., 2000).

Já na região costeira de Ubatuba, onde se encontram as enseadas analisadas neste trabalho, a principal atuação pertence à AC.

A AC é a massa de água que banha a costa brasileira (Figura 6) e que é definida como a mistura entre águas marinhas e águas de origem continental. Ela possui temperaturas maiores que $20^{\circ} \mathrm{C}$ e salinidades entre 33 e 33,7 (Miranda \& Katsuragawa, 1991; Kampel \& Gaeta, 2003). 
Essa massa de água domina a maior parte da água costeira da margem sudeste do Brasil, apesar de eventos de ressurgência, devido à penetração da ACAS, ocorrerem em alguns pontos dessa região com freqüência (Kampel \& Gaeta, 2003). Ela flui ao longo da costa sudeste brasileira, com fluxo residual predominantemente com rumo Nordeste (Mesquita, 1997).

Mais ao longo da costa, a região de Ubatuba está diretamente exposta às influências do mar aberto e, por isso, sujeita a hidrodinamismo acentuado principalmente durante o inverno, com a passagem das frentes frias pela região. Ainda assim, Rodrigues et al. (2002) indicam, nos estudos que realizaram nessa área, ambiente de baixo a médio grau de energia, atribuindo caráter eventual à atuação dos processos mais energéticos.

De acordo com Furtado \& Mahiques (1990), o processo oceanográfico que mais influencia o assoalho marinho da região costeira de Ubatuba é a ação das ondas. Elas se formam em oceano aberto, sendo associadas à circulação atmosférica (ventos alísios e frentes frias) e são as responsáveis pelos processos sedimentares que ocorrem no assoalho oceânico, tanto na região costeira quanto na plataforma interna.

As ondas de direção SW-SE associam-se à passagem das frentes frias que são mais intensas no inverno, apesar de ocorrerem durante todo o ano. Elas são relativamente mais energéticas e são importantes para o retrabalhamento dos sedimentos previamente depositados. Já as ondas de direção E-NE associam-se às fases pós-frontais contribuindo para a dinâmica de fundo oceânica apenas durante o inverno (Rodrigues, 2006).

Quando essas ondas se quebram na região costeira há a formação de correntes de deriva litorânea, que são um dos principais fatores responsáveis pela ressuspensão e pelo transporte dos sedimentos de fundo oceânico dessa área (Rodrigues, 2006).

\section{Descrição das Enseadas do Flamengo e da Fortaleza}

A área de estudo desse trabalho corresponde às enseadas do Flamengo e da Fortaleza, em Ubatuba, (S.P.), compreendidas entre as coordenadas $23^{\circ} 30.078^{\prime}$ a $23^{\circ}$ 30.260' S e $45^{\circ} 07.014^{\prime}$ a $45^{\circ} 08.163$ ' W (Figura 7). 
A Enseada do Flamengo é um embaiamento de formato trapezoidal com direção $\mathrm{N}-\mathrm{S}$ aberto diretamente para o mar. Ela possui superfície de aproximadamente $18 \mathrm{~km}^{2}$, largura média de $2,5 \mathrm{~km}^{2}$ e profundidades máximas de $14 \mathrm{~m}$, com as linhas de isóbatas desenvolvendo-se para o interior da enseada em conformidade com sua fisiografia, apresentando-se aproximadamente paralelas entre si, indicando profundidades cada vez menores. Sua desembocadura está voltada para o Sul, possuindo 2,3 km (Figura 7) e apresentando perfil assimétrico, com suas maiores profundidades localizadas em sua extremidade oeste (Mahiques, 1992).

Em sua porção mais interior há uma extensa praia, a nordeste, denominada Praia da Enseada, além de duas pequenas baías: o Saco do Perequê-Mirim, situado ao Norte, e o Saco da Ribeira, a Nordeste (Figura 7). Este último apresenta um canal, com profundidades mínimas de $3 \mathrm{~m}$, que se inicia na região do estrangulamento das pontas do Lagosteiro e do Flamengo e se alonga para Oeste.

A Enseada do Flamengo é um ambiente semi-confinado, cujo padrão de circulação caracteriza-se pela entrada de correntes vindas do sul, pelo lado ocidental da enseada. Estas correntes, após margearem a costa ocidental, bifurcam-se, indo para o Saco da Ribeira e costa oriental (Magliocca \& Kutner, 1965). Esse padrão de circulação condiciona a distribuição dos sedimentos de superfície e de fundo, havendo deposição de sedimentos mais grossos na costa ocidental e sedimentos mais finos no lado oriental da enseada. Apesar de os sedimentos variarem de silte a areia fina, há o predomínio de sedimentos de natureza essencialmente lamosa, preponderando siltes grossos a finos, onde os termos mais finos são encontrados na porção mais interna do Saco da Ribeira e ao longo da desembocadura da enseada (Mahiques, 1992). Os sedimentos são, geralmente, mal a muito mal selecionados, refletindo maior complexidade do padrão hidrodinâmico atuante nessa área (Mahiques, 1992), além de sugerirem ambiente de baixa energia deposicional, característico de circulação restrita.

Segundo Mahiques (1992), a Enseada do Flamengo apresenta teores de carbonato biodetrítico que indicam sedimento litoclástico na maior porção da enseada. Apenas no costão rochoso da Ponta Grande, na desembocadura da enseada e a leste o sedimento é litobioclástico; e em uma pequena área de maior dinâmica deposicional, próxima ao Boqueirão, o sedimento é bioclástico. A variação nos teores de carbonato da enseada é grande, o que indica maior concentração de matéria orgânica em suas áreas 
mais protegidas, ou seja, a oeste e na região da desembocadura próxima ao Canal do Boqueirão (Sanches, 1992).

Na porção oeste da Enseada do Flamengo há ação hidrodinâmica mais intensa, onde há entrada de água marinha através das correntes de fundo (Magliocca \& Kutner, 1965), na qual ocorre aporte local de sedimentos mais grossos (Eichler, 1982). Observam-se, ainda, fenômenos importantes de ressuspensão de sedimentos que acontecem em períodos de turbulência das águas, quando há eutrofização das águas locais (Teixeira, 1980); e ausência de variações sazonais consideráveis.

A rede de drenagem local é constituída por pequenos cursos de água que, geralmente, não contribuem com volume considerável de água; e pelo rio PerequêMirim, que deságua no Saco homônimo. Entretanto, durante épocas de maior pluviosidade, há aporte de grande quantidade de fragmentos vegetais e sedimentos continentais (Mahiques, 1992).

A Enseada da Fortaleza é uma reentrância da costa de formato triangular que possui área de $12 \mathrm{~km}^{2}$ (Figura 7). Sua desembocadura tem cerca de $5 \mathrm{~km}$ de largura e está voltada para SSE. É nela que se encontram as maiores profundidades da enseada, da ordem de $11 \mathrm{~m}$. Ela possui perfil simétrico, de declividade suave. Rumo ao continente, a enseada se torna mais estreita e rasa, com as isóbatas assumindo a conformação geral da linha de costa (Mahiques, 1992).

Ela apresenta 12 pequenas praias de bolso, delimitadas por pontões do embasamento. Esses afloramentos configuram à enseada aspecto de fortaleza, que em épocas distantes abrigavam embarcações do mal tempo, bem como corsários e traficantes negreiros que se escondiam da rota Santos - Rio de Janeiro (www.litoralvirtual.com.br).

Seu padrão de circulação é semelhante ao da Enseada do Flamengo, com correntes cujo sentido de circulação é horário. Seus sedimentos apresentam certa homogeneidade, havendo predomínio de areias muito finas. Essas areias gradam para siltes grossos em dois pontos: um em que se prolongam da Praia Vermelha para leste; e outro, limitado às imediações da Ponta Grande (Mahiques, 1992). Com exceção das praias Vermelha e do Lázaro, os sedimentos são de bem a moderadamente selecionados, o que imprime a esta enseada maior energia depocisional que aquela encontrada na Enseada do Flamengo. 
Os teores de carbonato biodetrítico indicam presença de sedimento litoclástico em quase toda a extensão da enseada, com exceção de uma área abrigada na Ponta do Sununga e outra na desembocadura do embaiamento, onde os teores de carbonato biodetrítico indicam sedimentos litobioclásticos (Mahiques, 1992).

A Enseada da Fortaleza recebe a descarga da bacia do Rio Escuro, que é uma das mais volumosas da região de Ubatuba. 


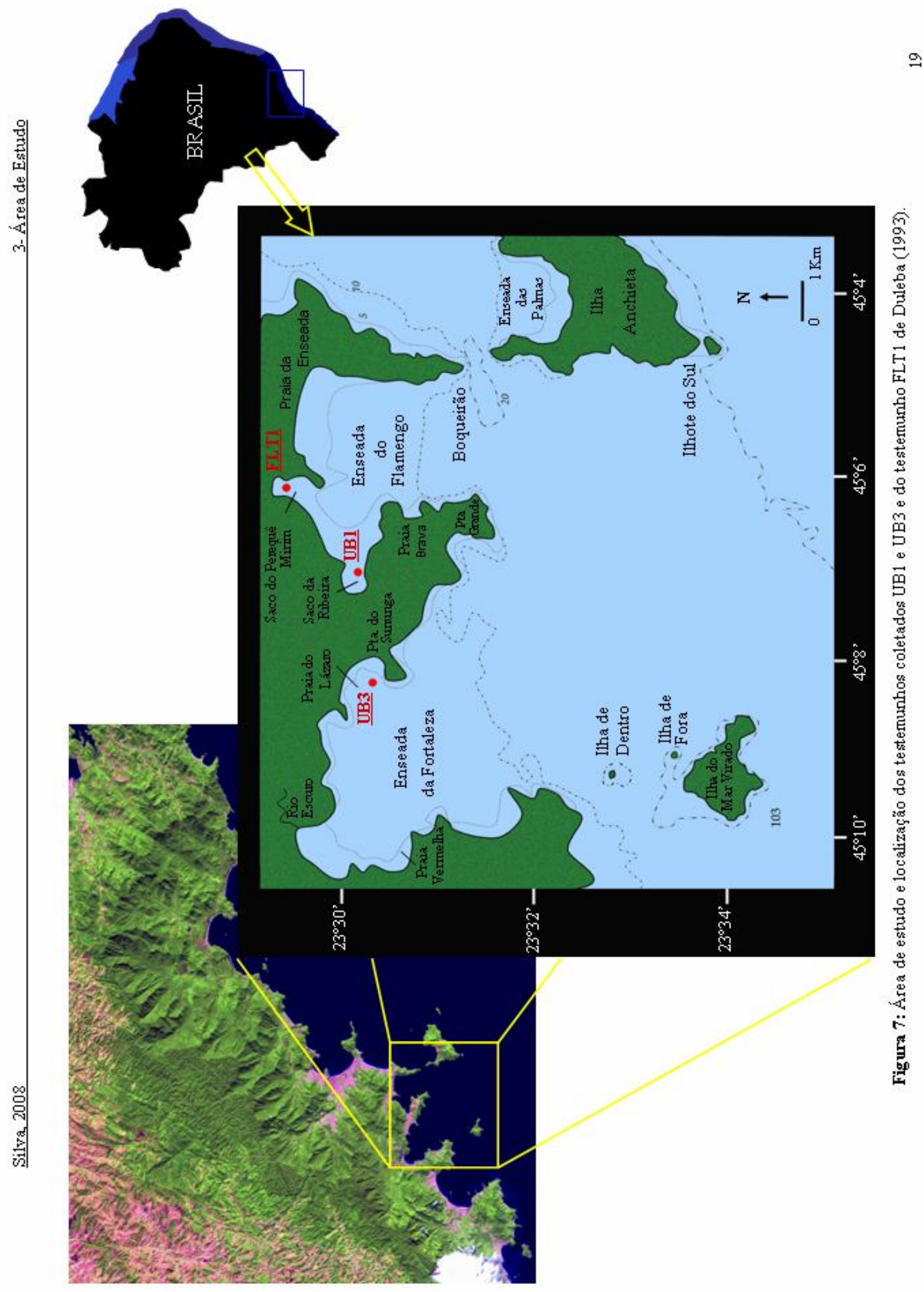




\section{CAPÍTULO 4: Materiais e Métodos}

\section{Procedência das Amostras e dos Dados Abióticos}

Os dois testemunhos analisados (UB1 e UB3), dos quais foram estudadas 58 amostras, foram gentilmente cedidos pelo Prof. Dr. Michel M. Mahiques, IOUSP. Estes testemunhos foram coletados sob lâmina de água de 3,10 m (UB1) e 3,80 m (UB3), a partir de um testemunhador a vibração, no Saco da Ribeira (UB1) e na Praia do Lázaro (UB3).

No Laboratório de Oceanografia Geológica, IOUSP, os testemunhos foram abertos, fotografados, medidos e descritos (cor, textura, estruturas sedimentares e componentes orgânicos). Níveis de matéria orgânica, fragmentos vegetais e conchas de moluscos bivalves em posição de vida foram coletados e datados por radiocarbono no laboratório Beta Analytic, Flórida (EUA).

Após terem sido realizadas a descrição e a coleta de material para datação, seções de dois centímetros de sedimentos foram amostradas a cada $10 \mathrm{~cm}$. Estas seções foram, posteriormente, subdivididas em três porções: uma destinada para análise granulométrica, outra para análise geoquímica, e a terceira para análise do conteúdo microfaunístico.

As análises granulométricas e geoquímicas foram realizadas no IOUSP, correspondendo ao trabalho de mestrado de Sonvesso (2007). Os métodos utilizados nessas análises sedimentológicas estão descritos em Sonvesso (2007).

As descrições macroscópicas, granulométricas, de datação radiométrica e geoquímicas dos testemunhos UB1 e UB3 foram feitas a partir de fotografias e de anotações originais da descrição dos testemunhos realizadas por Sonvesso, bem como dos dados abióticos apresentados em Sonvesso (2007), a partir dos dados originais.

Os resultados granulométricos e geoquímicos obtidos por Sonvesso (2007) foram retabulados e reinterpretados. Os dados granulométricos, de acordo com os parâmetros de classificação sedimentológica de Shepard \& Moore (1954) e de Folk \& Ward (1957). Os dados geoquímicos tiveram a origem da matéria orgânica (Razão C/N) classificada de acordo com Bordwosky (1965, apud Yoshikazu \& Massumoto, 2001) e o potencial de oxi-redução dos sedimentos (Razão C/S), de acordo com Borrego et al. 
(1998). A classificação sedimentológica baseada nos teores de $\mathrm{CaCO}_{3}$ foi feita segundo Larsonneur (1977, modificado por Dias, 1996).

Os sedimentos destinados à análise microfaunística e que são o objeto de estudo da presente dissertação foram tratados nos laboratórios de Micropaleontologia, Sedimentologia e Microscopia Eletrônica de Varredura do Instituto de Geociências da USP (IGc-USP), conforme descrito a seguir.

\section{Laboratório de Micropaleontologia, IGc-USP}

De cada uma das 58 amostras foi retirada alíquota de $10 \mathrm{cc}$ de sedimento, que foi peneirada a úmido em duas peneiras: 0,500 e 0,62mm (Schröder et al., 1987). As frações retidas nas peneiras foram secas em estufa $\left(60^{\circ} \mathrm{C}\right)$ e submetidas à análise densimétrica por flutuação-afundamento em tricloroetileno $\left(\mathrm{C}_{2} \mathrm{HCl}_{3}\right)$, visando separar os foraminíferos do sedimento (Scott et al., 2001).

Uma vez separadas do sedimento, as testas dos foraminíferos, independente de tamanho, coloração ou grau de fragmentação, foram triadas, fixadas com goma adragante em porta-foraminíferos (lâminas quadriculadas de fundo escuro), identificadas e contadas. Amostras com mais de 300 testas de foraminíferos foram subamostradas em microquarteador.

A classificação dos foraminíferos em nível de taxa superiores foi realizada segundo Loeblich \& Tappan $(1964,1988)$ e a identificação em nível de espécies em Boltovskoy et al. (1980), pranchas de trabalhos realizados na região de Ubatuba (Duleba, 1993) e nos exemplares da coleção micropaleontológica do IGcUSP.

Posteriormente, todas as carapaças triadas foram fotografadas em câmara digital, acoplada em microscópio estereoscópico. A partir das imagens digitais obtidas, foram feitas análises morfométricas, utilizando-se o analisador de imagens AnalySis. Testas foram agrupadas em pequenas $(<125 \mu \mathrm{m})$, médias $(125-250 \mu \mathrm{m})$, grandes $(250-500$ $\mu \mathrm{m})$ e macro $(>500 \mu \mathrm{m})$. Essa escala de determinação de tamanho das testas foi baseada na escala granulométrica de Wentworth (1922), construída para determinar tamanhos de grãos sedimentares em trabalhos geológicos. Os valores acima correspondem, respectivamente, aos tamanhos de grãos de areia muito fina, areia fina e areia média. 


\section{Laboratório de Microscopia Eletrônica de Varredura - IGcUSP}

Foram selecionados 61 foraminíferos das 58 amostras para serem fotografados no Microscópio Eletrônico de Varredura (MEV). A preparação desses foraminíferos para a sessão de fotomicrografias do MEV resumiu-se à colagem dos mesmos em fita adesiva de carbono, fixada previamente em suportes metálicos (stubs). Posteriormente, esses suportes foram inseridos no aparelho Sputter Coatting Emitech K550 e recobertos com ouro, por meio de injeção de argônio (Figura 8). Este procedimento permitiu a metalização das testas calcárias, tornando-as condutoras de elétrons, o que é essencial para a captação de imagens digitais no MEV.

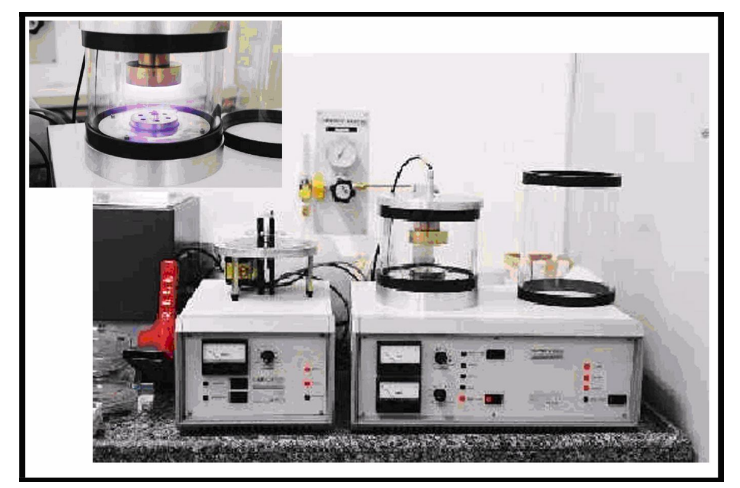

Figura 8: Sputter Coating Emitech K550. Detalhe: deposição de ouro na amostra. Foto: Isaac Sayeg

As imagens obtidas foram então tratadas no Laboratório de Micropaleontologia (IGc-USP), através do software Photoshop 7.0.1. Com as imagens tratadas, montaramse pranchas para ilustrar as espécies e as testas parcialmente fragmentadas encontradas nos testemunhos UB1 e UB3.

\section{$\underline{\text { Tratamento de Dados }}$}

A partir da identificação dos foraminíferos, foram realizados:

- Cálculo da densidade (número de testas encontrados em 10 cc), da riqueza de espécies (número de espécies) e da freqüência relativa das espécies. Esses dados foram agrupados em tabelas e gráficos; 
- Tabulação das espécies indicadoras da Água Costeira (AC), Água Tropical (AT), Água Central do Atlântico Sul (ACAS), de ambientes ricos em matéria orgânica ou de ambientes com circulação de fundo moderada a forte, óxicas ${ }^{2}$ e disaeróbicas ${ }^{3}$, da infauna e da epifauna. A identificação destas espécies bioindicadoras baseou-se nos trabalhos de Boltovskoy (1958), Murray (1991) e Duleba et al. (1999, 2005). Os dados obtidos foram plotados em gráficos de espécies indicadoras versus profundidade para UB1 e UB3.

- Análise tafonômica das testas, quantificando o número de testas preenchidas por sulfeto de ferro, monossulfeto de ferro ou matéria orgânica particulada, impregnadas por óxido de ferro, inteiras (i.e., sem vestígios de abrasão mecânica ou corrosão química), e parcial e totalmente fragmentadas. Esses dados foram compilados em gráficos de número de testas versus profundidade para os dois testemunhos;

- Análise de Correlação entre dados bióticos e abióticos dos testemunhos UB1 e UB3 por meio de dois métodos distintos:

- Análise de Correlação Canônica (ACC), por meio do programa Canoco para Windows 4.5 (ter Braak e Smilauer, 2002).

Para a realização desse estudo foram construídas duas matrizes: uma de variáveis ambientais (16 variáveis X 50 amostras), sendo essas variáveis provenientes dos dados obtidos para cada amostra dos dois testemunhos (Diâmetro Médio - DM, Desvio Padrão - DP, dados percentuais de granulometria do sedimento e porcentagens de carbonato de cálcio, de carbono, de nitrogênio e de enxofre, razão carbono/nitrogênio - C/N e razão carbono enxofre $-\mathrm{C} / \mathrm{S}$ ), e outra de dados microfaunísticos (17 espécies X 50 amostras), onde foram consideradas apenas as espécies mais representativas das 50 amostras analisadas. Ambas as matrizes foram construídas com a junção dos dados dos testemunhos UB1 e UB3.

\footnotetext{
${ }^{2}$ Espécies óxicas: espécies bentônicas que vivem em ambiente com >0.5 mL/L O 2 (Kaiho, 1994) ou > $1.0 \mathrm{~mL} / \mathrm{L} \mathrm{O}_{2}$ (Rhoads \& Morse, 1971, apud Kaiho, 1990).

${ }^{3}$ Espécies disaeróbicas: espécies bentônicas que vivem em ambiente com 0.1-0.3 mL/L O ${ }_{2}$ (Kaiho, 1994) ou 0.1-1.0 mL/L O 2 (Rhoads \& Morse, 1971, apud Kaiho, 1990).
} 
A relação de cada variável ambiental com a matriz de dados microfaunísticos foi verificada pelo teste estatístico de Monte Carlo (Manly, 1991), com 999 permutações.

- Cálculo do índice Ammonia-Elphidium (Índice A-E) de Sen Gupta et al. (1996), por meio da fórmula:

$$
\mathrm{A}-\mathrm{E}=\left[\mathrm{N}_{\mathrm{A}} /\left(\mathrm{N}_{\mathrm{A}}+\mathrm{N}_{\mathrm{E}}\right)\right] * 100, \text { onde: }
$$

A-E: Índice Ammonia - Elphidium;

$\mathrm{N}_{\mathrm{A}}$ : número de Ammonia parkinsoniana na amostra analisada;

$\mathrm{N}_{\mathrm{E}}$ : número de Cribroelphidium excavatum na amostra analisada.

Com os resultados obtidos, foram construídos gráficos dos valores do Índice Ammonia - Elphidium versus profundidade para os dois testemunhos. 


\section{CAPÍTULO 5: Resultados}

\section{Testemunho UB1}

\section{Descrição Macroscópica e Análises Granulométricas}

O testemunho UB1 apresenta $222 \mathrm{~cm}$ de profundidade (Figuras 9 e 10).

A partir do diagrama triangular de Shepard \& Moore (1954), pode-se observar que os sedimentos desse testemunho apresentam pouca heterogeneidade textural, agrupando-se principalmente na classe síltica (silte $-4,34 \%$ do total das amostras do testemunho, silte arenoso $-34,78 \%$ do total de amostras do testemunho e silte argiloso $-39,15 \%$ do total de amostras do testemunho). Secundariamente, ocorrem as classes areia síltica (13,04\% do total de amostras do testemunho) e areia (8,69\% do total de amostras do testemunho).

Pelos dados apresentados observa-se que as frações pelíticas do sedimento, menores que $63 \mu \mathrm{m}$, ocorrem na grande maioria das amostras (Tabela 1).

A sucessão basal é constituída por sedimentos arenosos que variam de areia $(222-220 \mathrm{~cm})$ a areia síltica $(220-200 \mathrm{~cm})$ (Figuras 9 e 10, Tabela 1), cujo diâmetro médio (DM) varia de 3,87 $\Phi$ a 4,9 $\Phi$. Essas areias são muito pobremente selecionadas, com desvio padrão (DP) variável de 2,4 $\sigma \Phi$ a 2,45 $\sigma \Phi$ e com predominância de areias finas (9 a 16\%) a muito finas (38 a 42\%) (Tabela 1). A fração lamosa é constituída principalmente por siltes (16 a 35\%), mas há presença conspícua de argilas (9 a 17\%) (Tabela 1). Essa fração tende a aumentar suas porcentagens rumo ao topo do testemunho (Tabela 1).

Essa porção basal é sobreposta, por contato gradacional, por sedimentos siltosos preto-esverdeados, que se estendem até $32 \mathrm{~cm}$ de profundidade. Esta sucessão sedimentar inicia-se com silte arenoso (200-182 cm), que grada para silte argiloso (182$92 \mathrm{~cm})$ que, por sua vez, grada, novamente, para silte arenoso $(92-32 \mathrm{~cm})$. Ela é 
constituída por alta porcentagem de silte (72 a 45\%) e de argila (16 a $25 \%$ ) e, baixa porcentagem de areia fina (1 a 6\%) e muito fina (5 a 20\%). As porcentagens de lama aumentam progressivamente de 192 a $92 \mathrm{~cm}$ de profundidade e, posteriormente, tendem a diminuir, rumo ao topo do testemunho. Ao longo dessa sucessão, ocorrem esparsos fragmentos biodetríticos, os quais tendem a aumentar entre 72 e $50 \mathrm{~cm}$ de profundidade. Particularmente, entre a profundidade de 144 a $140 \mathrm{~cm}$, ocorre um nível conspícuo de matéria orgânica. Em torno de 112-100 $\mathrm{cm}$ de profundidade, ocorrem fragmentos vegetais. O diâmetro médio $(\mathrm{DM})$ varia de 5,8 $\Phi$ a 6,4 $\Phi$, e o desvio padrão (DP) de 2,41 $\sigma \Phi$ a 1,81 $\sigma \Phi$, ou seja, constata-se predominância de sedimentos pobremente selecionados.

À sucessão síltica, sobrepõem-se, abruptamente, sedimentos arenosos, que se estendem até a profundidade de $12 \mathrm{~cm}$. Entre 32 e $22 \mathrm{~cm}$ de profundidade, ocorre areia, destituída de fragmentos biodetríticos, cujas porcentagens são mais altas (grânulos $5 \%$, areia muito grossa $-9,4$ a $15 \%$, areia grossa - 17 a $25 \%$, areia média - em torno de $15 \%$, areia fina - 9 a 20\%, e areia muito fina - 17 a $4 \%$ ). De 22 a $12 \mathrm{~cm}$ de profundidade, observa-se areia síltica, com fragmentos vegetais. O DM varia de 2,37 $\Phi$ a 2,42 $\Phi$ e o DP, $2,31 \sigma \Phi$ a $2,97 \sigma \Phi$.

Rumo ao topo do testemunho, a areia síltica grada para silte arenoso, rico em fragmentos biodetríticos. Nos doze primeiros centímetros do testemunho, as porcentagens de lama variam de 52 a 62\% (DM 4,11 a 4,97 Ф e DP 2,43 a 2,39 бФ).

Essas duas últimas sucessões sedimentares apresentam granodecrescência ascendente (Figura 9).

\section{Análises Radiométricas $\left({ }^{14} \mathrm{C}\right)$}

Uma concha de bivalve encontrada em posição de vida na base do testemunho UB1 foi datada por ${ }^{14} \mathrm{C}$ em $7.290 \pm 40$ anos A.P. No intervalo de 166-168 cm, uma concha de bivalve foi datada por ${ }^{14} \mathrm{C}$ em $6.530 \pm 40$ anos A.P. e, entre 144 e $140 \mathrm{~cm}$ de profundidade, ocorre um nível de matéria orgânica que teve fragmentos vegetais (madeira) datados em $5.040 \pm 40$ anos A.P. (Figura 9). A $66 \mathrm{~cm}$ de profundidade, uma concha de bivalve foi datada por ${ }^{14} \mathrm{C}$ em $4.470 \pm 40$ anos A.P. e a $15 \mathrm{~cm}$ de

profundidade, fragmentos vegetais (madeira) foram datados por ${ }^{14} \mathrm{C}$ em $110 \pm 40$ anos 
A.P (Figuras 9 e 10). Entretanto, essa última idade encontrada ultrapassa o limite de idade mínima (300 anos A. P) para o qual o método de datação utilizado é considerado confiável (Suguio, com. pessoal).

\section{$\underline{\text { Análise geoquímica }}$}

A maioria das amostras do testemunho UB1 apresenta teores de $\mathrm{CaCO}_{3}$ que oscilam entre 7 e $28 \%$, ou seja, os sedimentos são predominantemente litoclásticos (Figura 10, Tabela 2). Somente no intervalo compreendido entre 72 e $50 \mathrm{~cm}$ de profundidade é que são observados valores acima de 30\%, ocorrendo sedimentos litobioclásticos. $\mathrm{O}$ padrão de distribuição dos teores de $\mathrm{CaCO}_{3}$, ao longo do testemunho, caracteriza-se pelo aumento progressivo de seus valores da base $(8,7 \%)$ até a profundidade de $72 \mathrm{~cm}$ (42\%). De 72 a $50 \mathrm{~cm}$ de profundidade, onde foi constatado nível rico em conchas de bivalves (Figuras 9 e 10), há aumento considerável dos teores de carbonato de cálcio, os quais passam a variar de 42 a $38 \%$. Rumo ao topo do testemunho, os teores decrescem abruptamente para 7\%. Particularmente nos níveis de areia e areia síltica, posicionados entre 22 e $20 \mathrm{~cm}$ de profundidade, ocorrem os menores teores de $\mathrm{CaCO}_{3}$ do testemunho UB1. Nos primeiros $12 \mathrm{~cm}$ de profundidade, os teores voltam aumentar ligeiramente (17 a 13\%) (Figura 10, Tabela 2).

Os valores percentuais de carbono orgânico $\left(\% \mathrm{C}_{\text {org. }}\right.$.) variam de 0,4 a 1,7\%. De modo geral, a maioria desses valores oscila em torno de 1\%. Os menores valores são encontrados na base do testemunho $(222-220 \mathrm{~cm})$ e entre 22 e $20 \mathrm{~cm}$ de profundidade (Figura 10). O padrão de distribuição das porcentagens de $\mathrm{C}_{\text {org }}$. caracteriza-se por aumento progressivo, da base de UB1 até a profundidade de $172 \mathrm{~cm}$. De $172 \mathrm{~cm}$ de profundidade rumo ao topo deste testemunho, as porcentagens tendem a diminuir progressivamente. Nos primeiros $20 \mathrm{~cm}$ de profundidade, os valores de $\mathrm{C}_{\text {org }}$. voltam a aumentar.

O padrão de distribuição dos valores percentuais de nitrogênio total ( $\left.\% \mathrm{~N}_{\text {total }}\right)$ é semelhante ao padrão do carbono orgânico (Figura 10), ou seja, seus valores aumentam da base de UB1 até a profundidade de $162-160 \mathrm{~cm}$, quando atingem seu valor máximo $(0,14 \%)$. Rumo ao topo do testemunho, decrescem progressivamente, atingindo o valor mínimo entre 22 e $20 \mathrm{~cm}$ de profundidade (0,034\%). De $20 \mathrm{~cm}$ de profundidade ao topo, os valores aumentam novamente (Figura 10, Tabela 2). 
Os valores percentuais de enxofre ( $\left.\% \mathrm{~S}_{\text {total }}\right)$ aumentam da base do testemunho até a profundidade de $180 \mathrm{~cm}$ e, a partir daí, diminuem progressivamente rumo ao topo do testemunho (Figura 9). O menor valor $(0,19 \%)$ ocorre no intervalo compreendido entre 12 e $10 \mathrm{~cm}$ e o maior (1,17\%), na profundidade de 182 a $180 \mathrm{~cm}$ (Figura 10, Tabela 2).

Os valores da razão C/N variam de 11 a 13 da base até a profundidade de 152 $\mathrm{cm}$, indicando a presença de matéria orgânica de origem mista (i.e., marinha e continental). De 152 a $80 \mathrm{~cm}$ de profundidade, os valores são maiores que 15, indicando matéria orgânica de origem continental. De $80 \mathrm{~cm}$ de profundidade rumo ao topo do testemunho, volta ocorrer matéria orgânica de origem mista (Figura 10).

A maioria dos valores da razão C/S oscila em torno de 1 a 2, indicando a presença de sedimentos depositados em ambiente redutor (Figura 10, Tabela 2). Somente nos últimos $10 \mathrm{~cm}$ do testemunho é que passam a ocorrer valores em torno de 6 , indicativos de ambiente oxidante (Figura 10).

Os valores de $\delta^{13} \mathrm{C}$ oscilam entre $-24,4$ a $-22,1$, indicando presença de plantas de ciclos fotossintéticos C3 e C4 (Tabela 2), com maior influência de plantas C3. Eles inferem, portanto, matéria orgânica de origem mista (continental e marinha) ou de origem continental para o Saco da Ribeira (Tabela 2). 


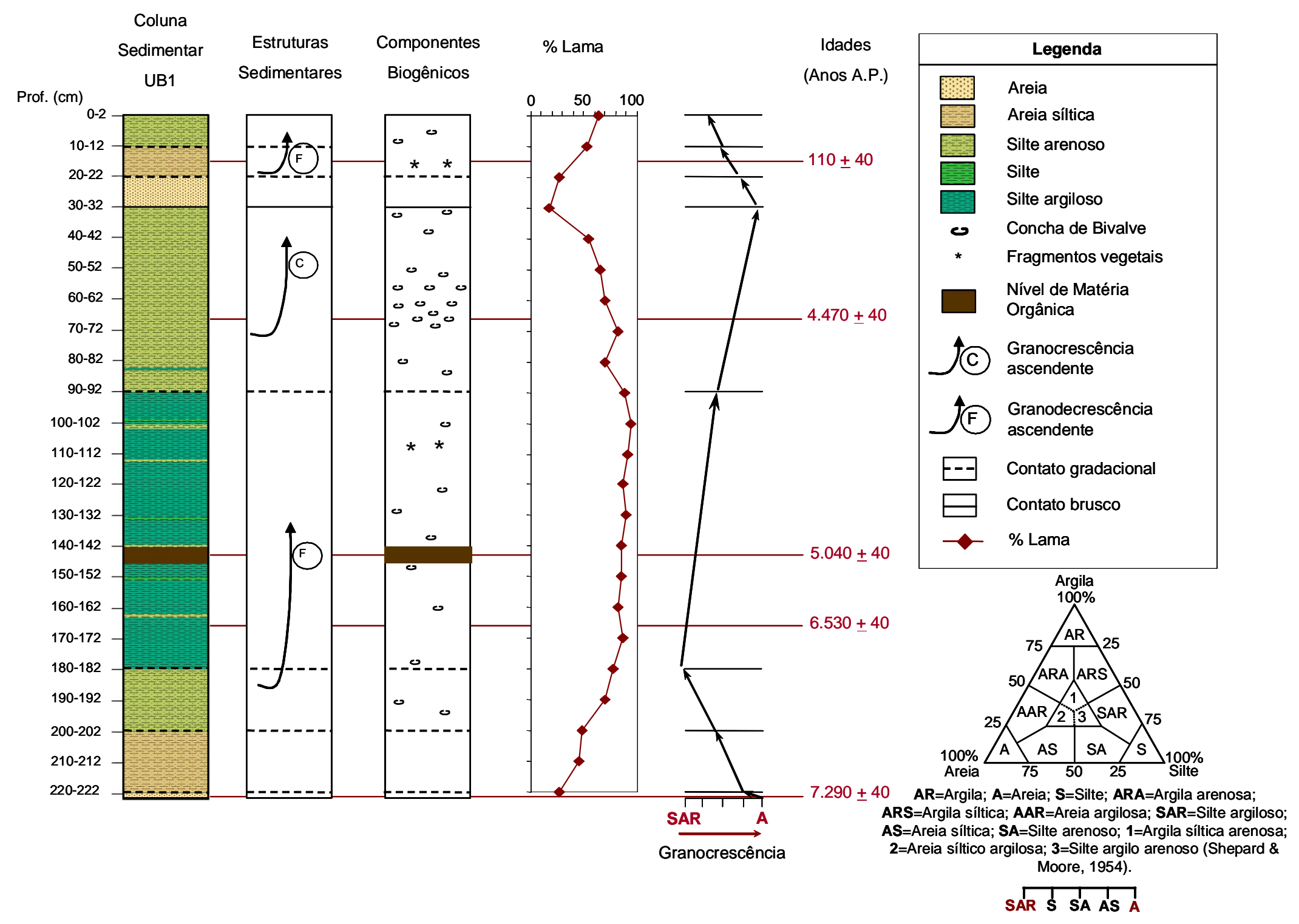

Figura 9: Coluna sedimentar, estruturas sedimentares, componentes biogênicos, granulometria e datação radiométrica $\left({ }^{14} \mathrm{C}\right)$ do testemunho UB1 


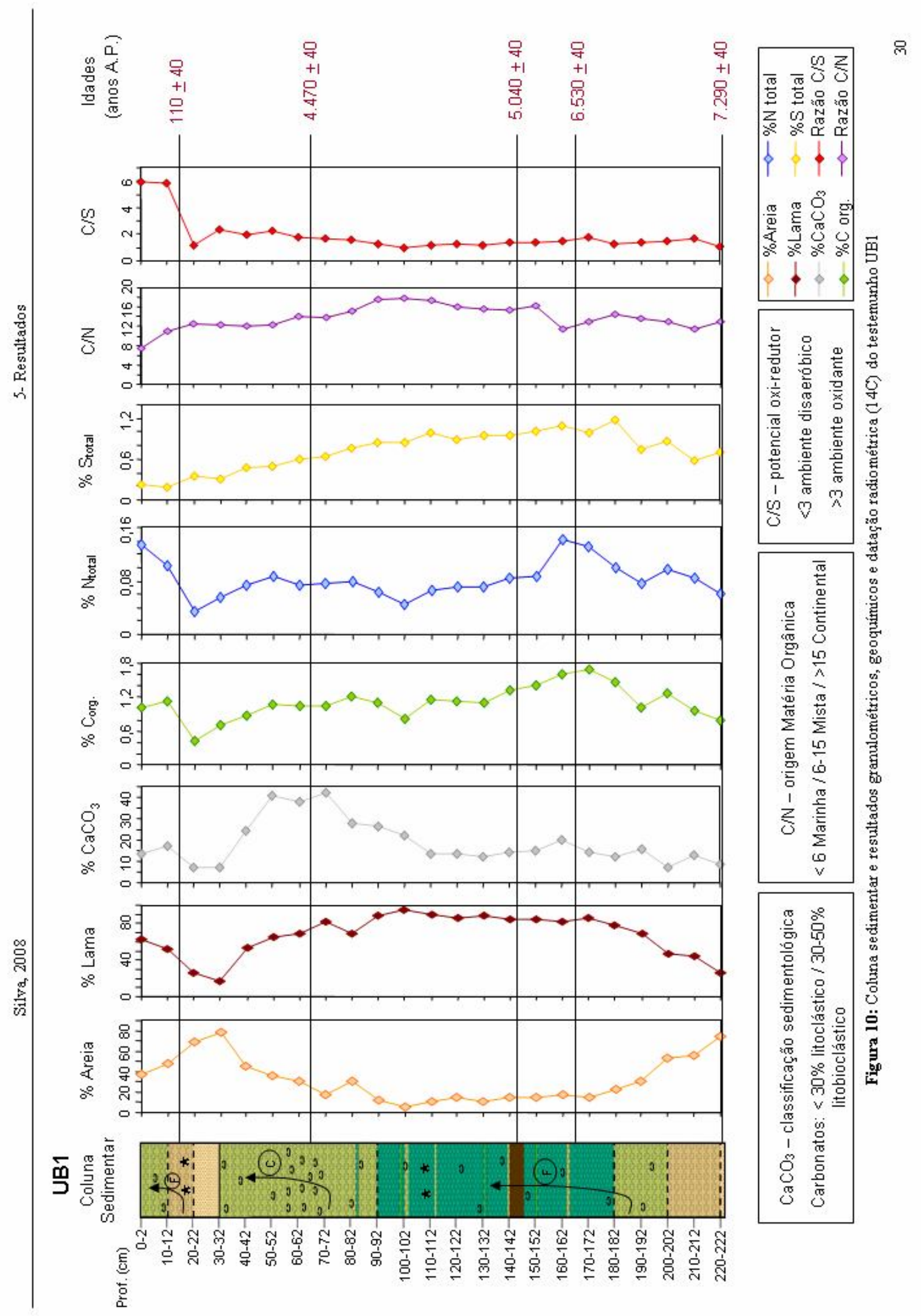




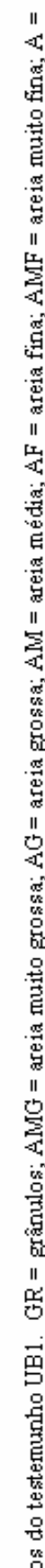

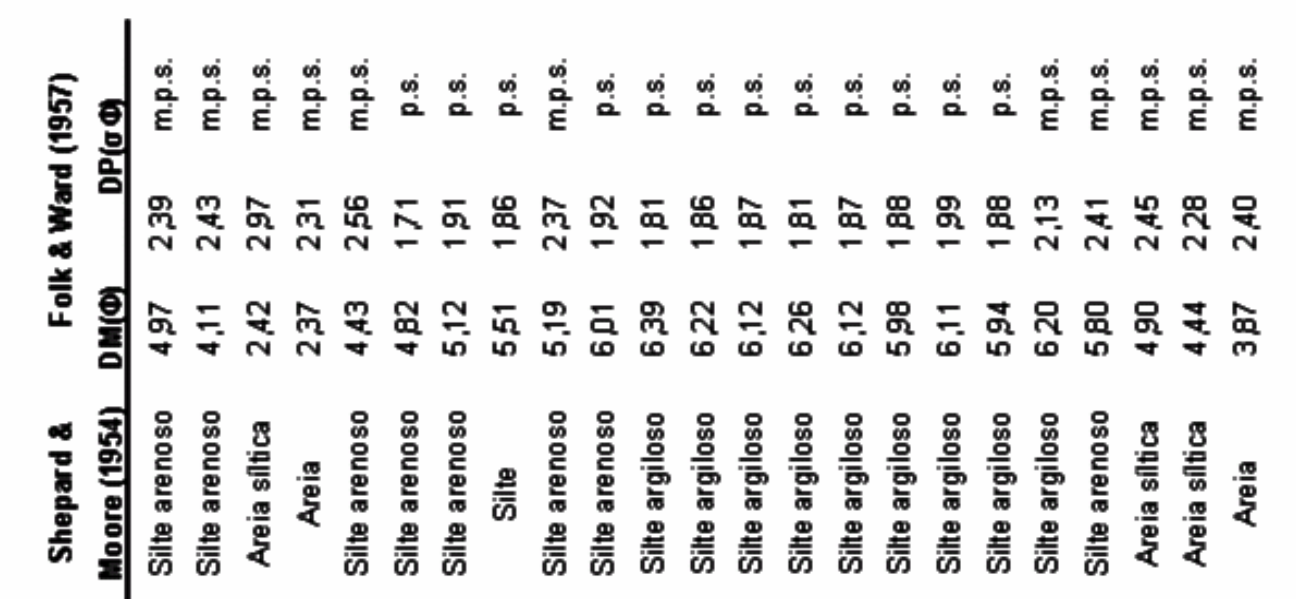

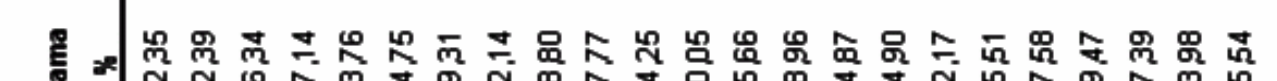

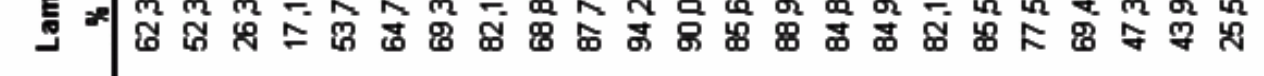

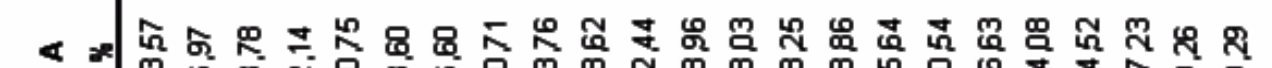
n

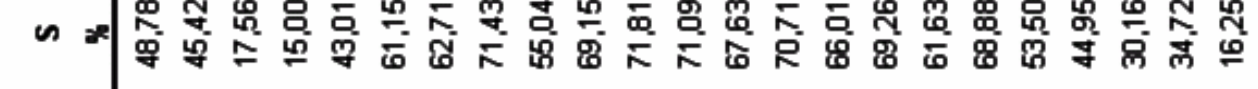

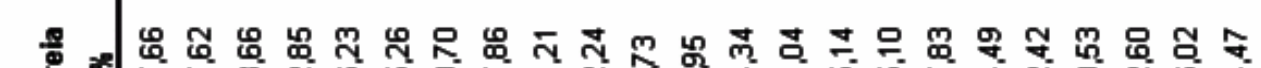

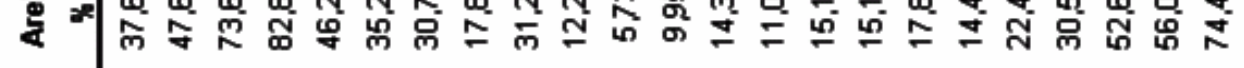

宸

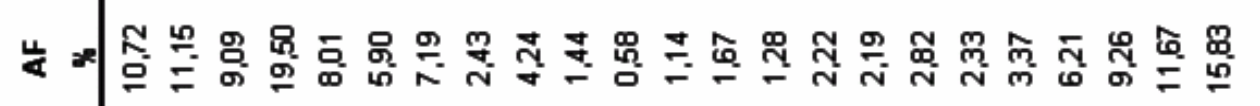
₹

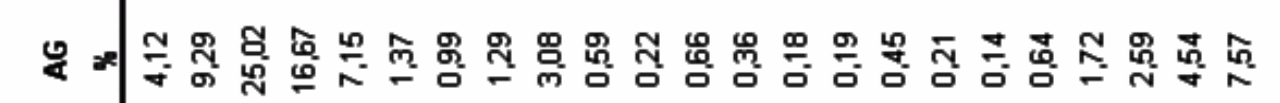

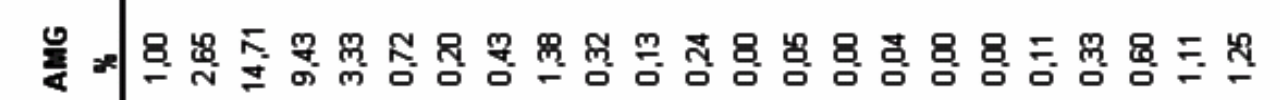

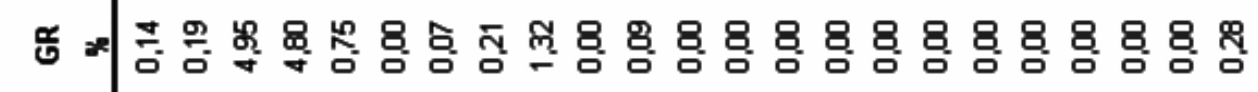




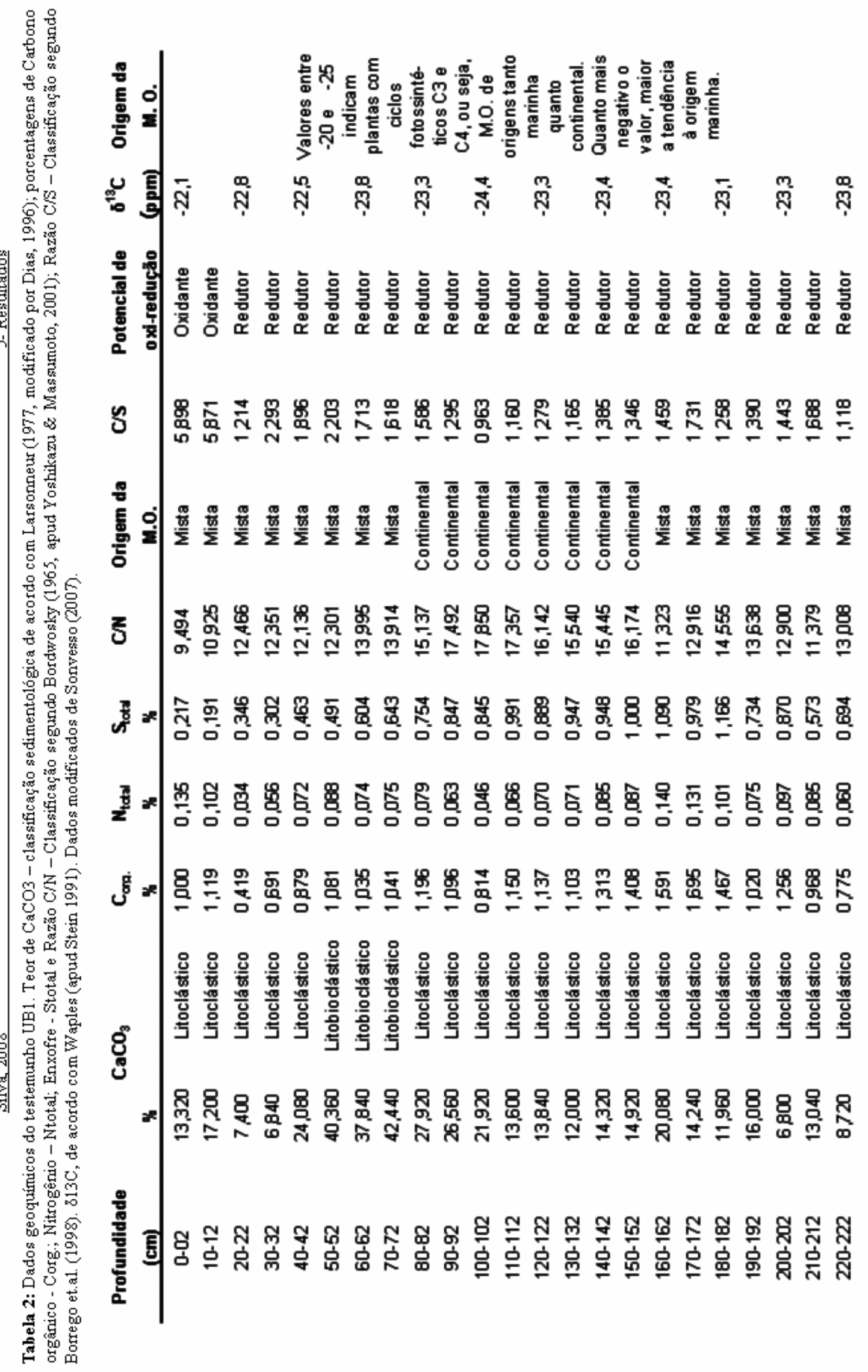




\section{Testemunho UB3}

\section{Descrição Macroscópica e Análises Granulométricas}

O testemunho UB3 apresenta $342 \mathrm{~cm}$ de profundidade (Figuras $11 \mathrm{e} \mathrm{12).}$

Com base nas amostras e no diagrama triangular de Shepard \& Moore (1954) é possível identificar cinco classes de sedimentos: areia $(8,57 \%$ do total de amostras do testemunho), areia síltica (11,43\% do total de amostras do testemunho), silte arenoso $(11,43 \%$ do total de amostras do testemunho), silte argiloso $(11,43 \%$ do total de amostras do testemunho) e silte $(57,14 \%$ do total de amostras do testemunho). O diâmetro médio (DM) varia de 2,28 a 5,96 Ф e o desvio padrão (DP), de 0,27 a 1,98 $\sigma \Phi$ (Figuras 11 e 12, Tabela 3).

A base do testemunho é composta por areia $(342-312 \mathrm{~cm})$ e areia síltica (312 $300 \mathrm{~cm})$, com grau de seleção variável de muito bem selecionado $(342-340 \mathrm{~cm})$ a pobremente selecionado $(332-300 \mathrm{~cm})$, que se caracteriza pela ausência de estruturas sedimentares e componentes biogênicos. O DM varia de 2,28 a 4,21 Ф e o DP, de 0,27 a $1,61 \sigma \Phi$.

À sucessão basal, sobrepõem-se, gradualmente, sedimentos sílticos (89 a 44\% do total das amostras) pobremente selecionados, que se estendem até a profundidade de 32 $\mathrm{cm}$. Esses sedimentos sílticos apresentam granodecrescência ascendente da base da sucessão até $250 \mathrm{~cm}$ de profundidade. Nesse intervalo, ocorrem siltes arenoso a argiloso, os quais apresentam contatos gradacionais entre si (Figura 11).

De $250 \mathrm{~cm}$ até $62 \mathrm{~cm}$ de profundidade, passa a ocorrer silte, com finas laminações de silte argiloso e de areia fina (Figuras 11 e 12). A $60 \mathrm{~cm}$ de profundidade, esse silte grada para silte argiloso que se estende até $52 \mathrm{~cm}$, a partir de onde é sobreposto gradacionalmente por silte arenoso que se deposita até $32 \mathrm{~cm}$ de profundidade. Entre $210 \mathrm{~cm}$ e $30 \mathrm{~cm}$ de profundidade, constata-se granocrescência ascendente nessa sucessão. As porcentagens de argila tendem a oscilar entre 0 e $21 \%$. As areias são muito finas, muito bem selecionadas, e apresentam baixas porcentagens (entre 39,95 e 1,6\%). Ao longo desta sucessão síltica são encontrados alguns fragmentos vegetais oxidados e biodetríticos. Estes últimos são particularmente abundantes entre $242 \mathrm{~cm}$ e $220 \mathrm{~cm}$ (Figuras 11 e 12). O DM fica entre 4,88 e 5,96 Ф e o DP, entre 1,28 e $1,98 \sigma \Phi$ (Tabela 3). 
A seqüência sedimentar seguinte $(30-10 \mathrm{~cm})$ é composta por areias sílticas, com aumento considerável na fração de areia muito fina (56 a 57\%), que se sobrepõem abruptamente à sucessão sotoposta. Essas areias também apresentam fragmentos vegetais oxidados e biodetríticos dispersos. As porcentagens de argila são baixas (entre 2 e 9\%), e as de silte situam-se entre 33 e 39\% (Tabela 3). O DM tem valores entre 4,02 e 4,31 $\Phi$ e o DP, entre 1,03 e $1,57 \sigma \Phi$.

Os primeiros dez centímetros do testemunho caracterizam-se por apresentar silte arenoso cinza-esverdeado, sem componentes biogênicos (Figuras 11 e 12). Esses sedimentos são pobremente selecionados, cuja fração arenosa é composta por areias muito finas. O Valor do DM é de $5 \Phi$ e do DP é 1,71 $\sigma \Phi$ (Tabela 3).

\section{Análises Radiométricas $\left({ }^{14} \mathrm{C}\right)$}

Conchas de bivalves foram datadas por ${ }^{14} \mathrm{C}$ em diversos intervalos de profundidade do testemunho UB3. A $312 \mathrm{~cm}$, em $7.530 \pm 40$ anos A.P; a $306 \mathrm{~cm}$, em $7.310 \pm 40$ anos A.P; a $202 \mathrm{~cm}$, em $5.320 \pm 40$ anos A.P; em torno de $88 \mathrm{~cm}$, em 4.840 \pm 40 anos A.P. e entre 38 e $36 \mathrm{~cm}$, em $4.550 \pm 40$ anos A.P.

\section{Análise geoquímica}

Excetuando a amostra do intervalo $242-240 \mathrm{~cm}$, que apresentou mais de $31 \%$ de $\mathrm{CaCO}_{3}$ (i.e, sedimentos litobioclásticos), as demais amostras apresentam teores que variam entre 1,3 a 29\% (Figura 12, Tabela 4). Portanto, os sedimentos encontrados no testemunho UB3 são essencialmente litoclásticos. Os menores teores $(1,3 \%$ a 8,2\%) são encontrados na base arenosa do testemunho (342 - $302 \mathrm{~cm}$ ). De 302 a $242 \mathrm{~cm}$, os teores de $\mathrm{CaCO}_{3}$ aumentam progressivamente. No intervalo entre 242 e $240 \mathrm{~cm}$, onde começa a ocorrer silte, é observado o maior o teor de $\mathrm{CaCO}_{3}$ (30,93\%). A partir deste intervalo até a profundidade de $142 \mathrm{~cm}$, os teores mantêm-se constantes, variando entre 26 e $27 \%$. De $142 \mathrm{~cm}$ ao topo do testemunho, os teores tendem a diminuir (Figura 12).

Os valores percentuais de carbono orgânico (\% $\mathrm{C}_{\mathrm{org}}$.) variam de 0,4 a $1,2 \%$ (Figura 12, Tabela 4). A curva de distribuição do $\mathrm{C}_{\text {org. é ligeiramente semelhante à }}$ curva do $\mathrm{CaCO}_{3}$. Por exemplo, na base arenosa pobre em carbonato também foram 
observados baixos valores de $\mathrm{C}_{\text {org. }}$. Posteriormente, estes valores tendem a aumentar nas sucessões síltico-argilosas e sílticas do testemunho (de 302 a $232 \mathrm{~cm}$ ). De $232 \mathrm{~cm}$ a 160 $\mathrm{cm}$ de profundidade, os valores voltam a diminuir, atingindo a porcentagem de 0,67\%. Posteriormente, tornam a aumentar, atingindo seu valor máximo a $142-140 \mathrm{~cm}$ de profundidade $(1,31 \%)$. Rumo ao topo do testemunho, os teores de $\mathrm{C}_{\text {org. }}$ diminuem progressivamente (Figura 12, Tabela 4).

Os valores percentuais de nitrogênio total ( $\% \mathrm{~N}_{\text {total }}$ ) oscilam entre 0,01 e $0,1 \%$. O padrão de distribuição destes valores ao longo do testemunho é bastante similar à distribuição do $\mathrm{C}_{\mathrm{org}}$. Na base arenosa os valores são relativamente baixos $(0,01)$. Já nas sucessões síltico-argilosas e sílticas, ocorrem os maiores valores $(0,085 \%)$. A partir de $240 \mathrm{~cm}$ rumo ao topo do testemunho, os valores voltam a diminuir, oscilando de 0,09 a 0,014\% (Figura 12, Tabela 4).

Os valores percentuais de enxofre total $\left(\% \mathrm{~S}_{\text {total }}\right)$ variam de $0,015 \%$ a $0,948 \%$. Esses valores aumentam da base do testemunho até $272-270 \mathrm{~cm}$, a partir de onde diminuem até $152-150 \mathrm{~cm}$. Sofrem aumento a $142-140 \mathrm{~cm}$ e, então, tornam a diminuir até o topo do testemunho. Os menores valores são encontrados nos intervalos de profundidade de $342-310 \mathrm{~cm}, 262-260 \mathrm{~cm}$ e $52-0 \mathrm{~cm}$. O maior valor é encontrado entre $142-140 \mathrm{~cm}$ e o menor, entre 262 e $260 \mathrm{~cm}$ (Figura 12, Tabela 4).

Os valores da razão C/N nos intervalos de profundidade de $342-330$ cm, 232-220 $\mathrm{cm}, 202-190 \mathrm{~cm}, 172-170 \mathrm{~cm}$ e $142-0 \mathrm{~cm}$ oscilam entre 39,685 e 15,351, indicando matéria orgânica de origem continental na Praia do Lázaro. Já nos intervalos de profundidade de $322-240 \mathrm{~cm}, 212-210 \mathrm{~cm}, 182-180 \mathrm{~cm}$ e $162-150 \mathrm{~cm}$, a razão $\mathrm{C} / \mathrm{N}$ possui valores entre 14,379 e 9,501, indicando a presença de matéria orgânica de origem mista (i.e., continental e marinha) na Praia do Lázaro. Valores anômalos (103 e 67) foram encontrados entre 32 e $30 \mathrm{~cm}$ e entre 22 e $20 \mathrm{~cm}$ de profundidade, respectivamente (Figura 12).

Os valores da razão $\mathrm{C} / \mathrm{S}$ variam de 1,165 a 5,093. A maioria dos valores dessa razão oscila entre 1 e 3 , indicando que o ambiente da Praia do Lázaro foi majoritariamente redutor. Contudo, entre 332 e $330 \mathrm{~cm}(\mathrm{C} / \mathrm{S}=3,815) ; 192$ e $190 \mathrm{~cm}$ $(\mathrm{C} / \mathrm{S}=3,125)$ e entre $22-20 \mathrm{~cm}(\mathrm{C} / \mathrm{S}=5,093)$, os valores da razão $\mathrm{C} / \mathrm{S}$ indicam ambiente deposicional oxidante para essa enseada. Entre 262 e $260 \mathrm{~cm}$ foi encontrado valor anômalo ( $\mathrm{C} / \mathrm{S}=66,667)$; (Figura 12). 
Os valores de $\delta^{13} \mathrm{C}$ encontrados no testemunho UB3 oscilam entre $-23,7$ e $-22,4$, indicando a presença de espécies vegetais de ciclos fotossintéticos $\mathrm{C} 3$ e $\mathrm{C} 4$, ou seja, de matéria orgânica de origem continental e marinha na Praia do Lázaro (Tabela 4). 


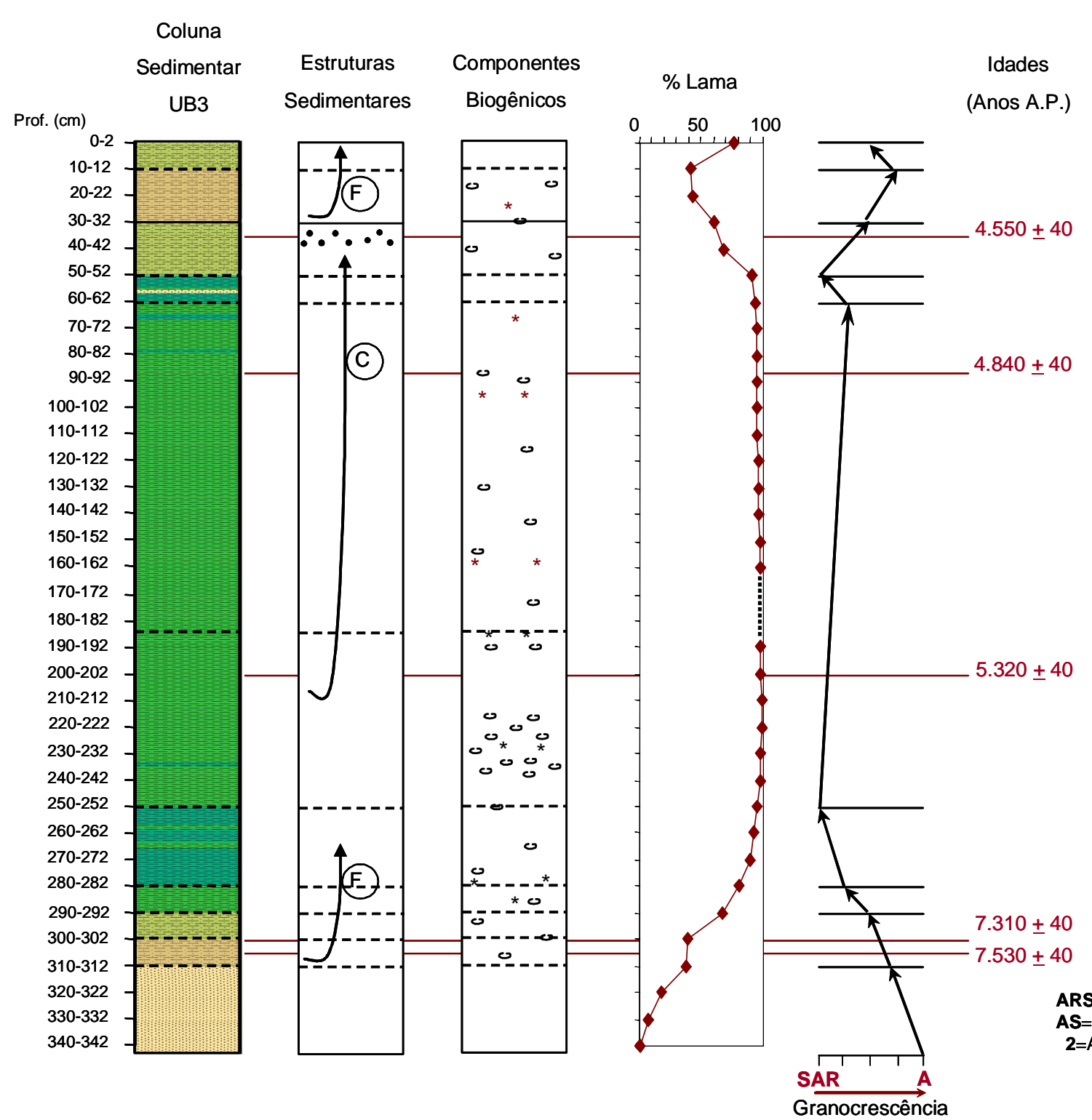

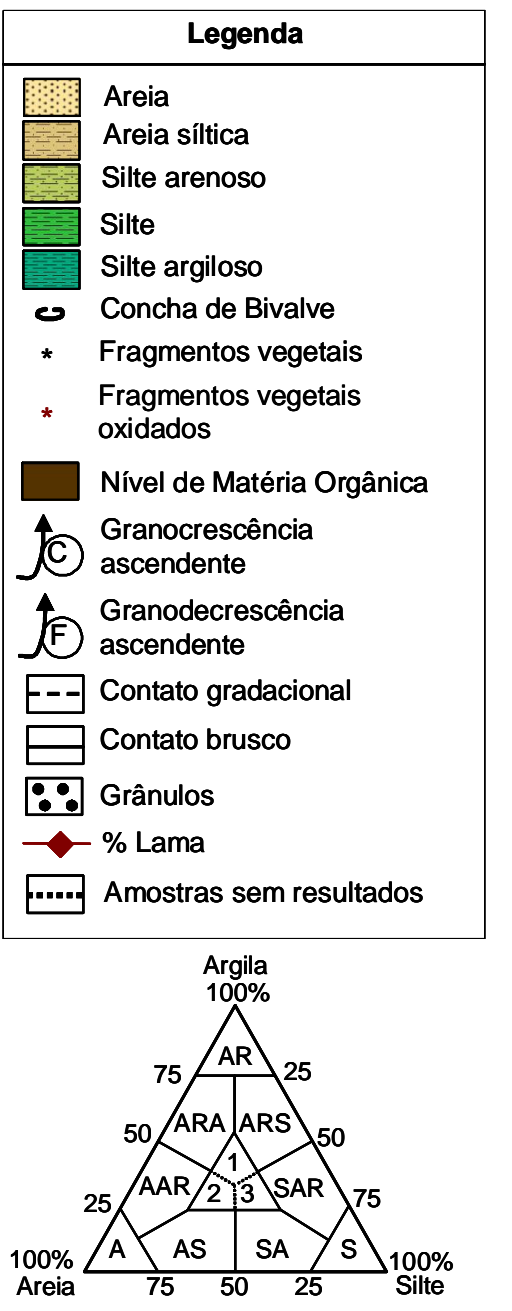

$\mathbf{A R}=$ Argila; $\mathbf{A}=$ Areia; $\mathbf{S}=$ Silte; $\mathbf{A R A}=$ Argila arenosa; ARS=Argila síltica; $\mathbf{A A R}=$ Areia argilosa; $\mathbf{S A R}=$ Silte argiloso; $\mathbf{A}=$ =Areia sítica; $\mathbf{S A}=S$ ilte arenoso; $\mathbf{1}=$ Argila siltica arenosa $\mathbf{2 = A r e i a ~ s i ́ l t i c o ~ a r g i l o s a ; ~} \mathbf{3}=$ Silte argilo arenoso (Shepard \&

$$
\text { Moore, 1954). }
$$

Figura 11: Coluna sedimentar, estruturas sedimentares, componentes biogênicos, granulometria e datação radiométrica $\left({ }^{14} \mathrm{C}\right)$ do testemunho UB3 


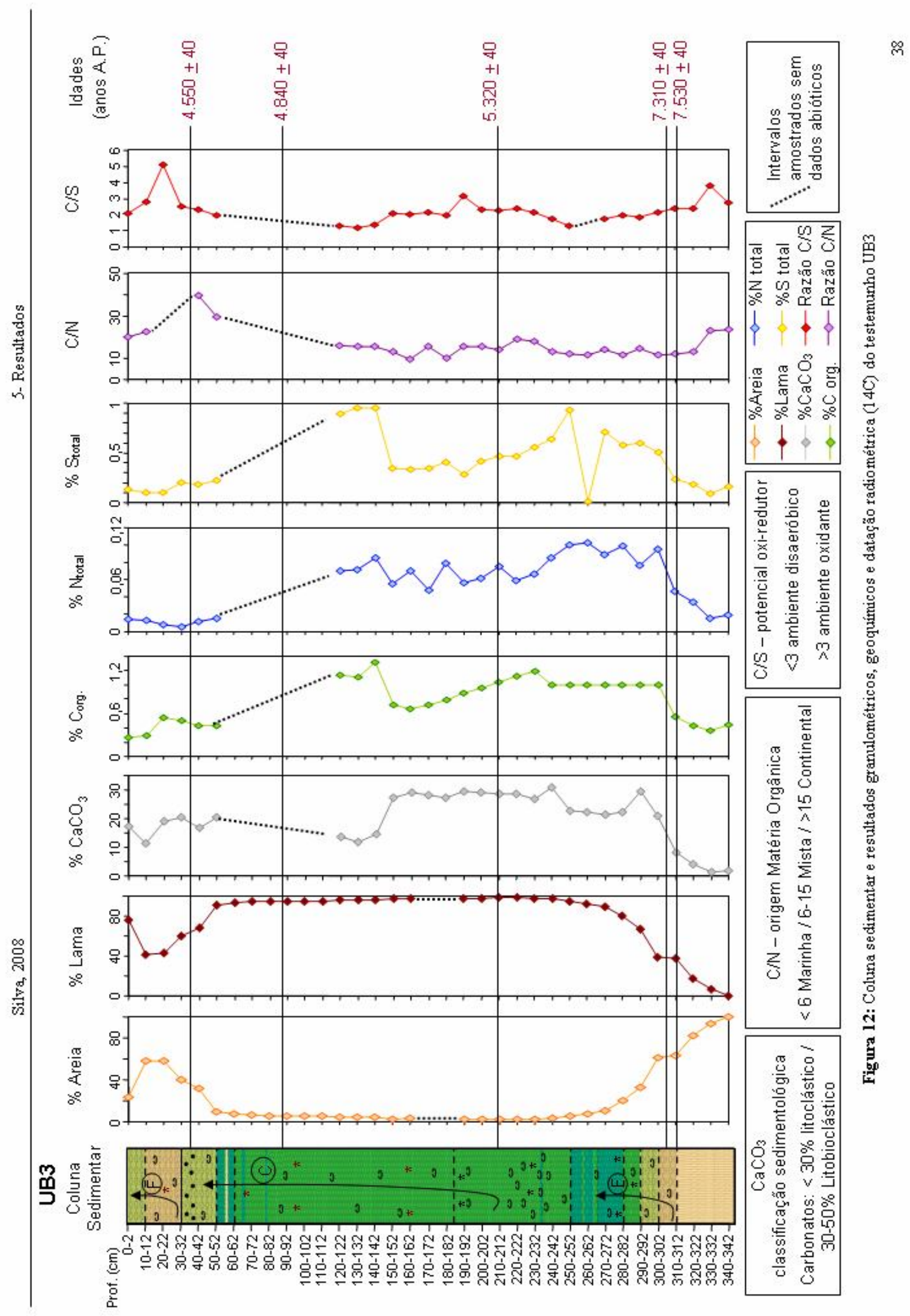




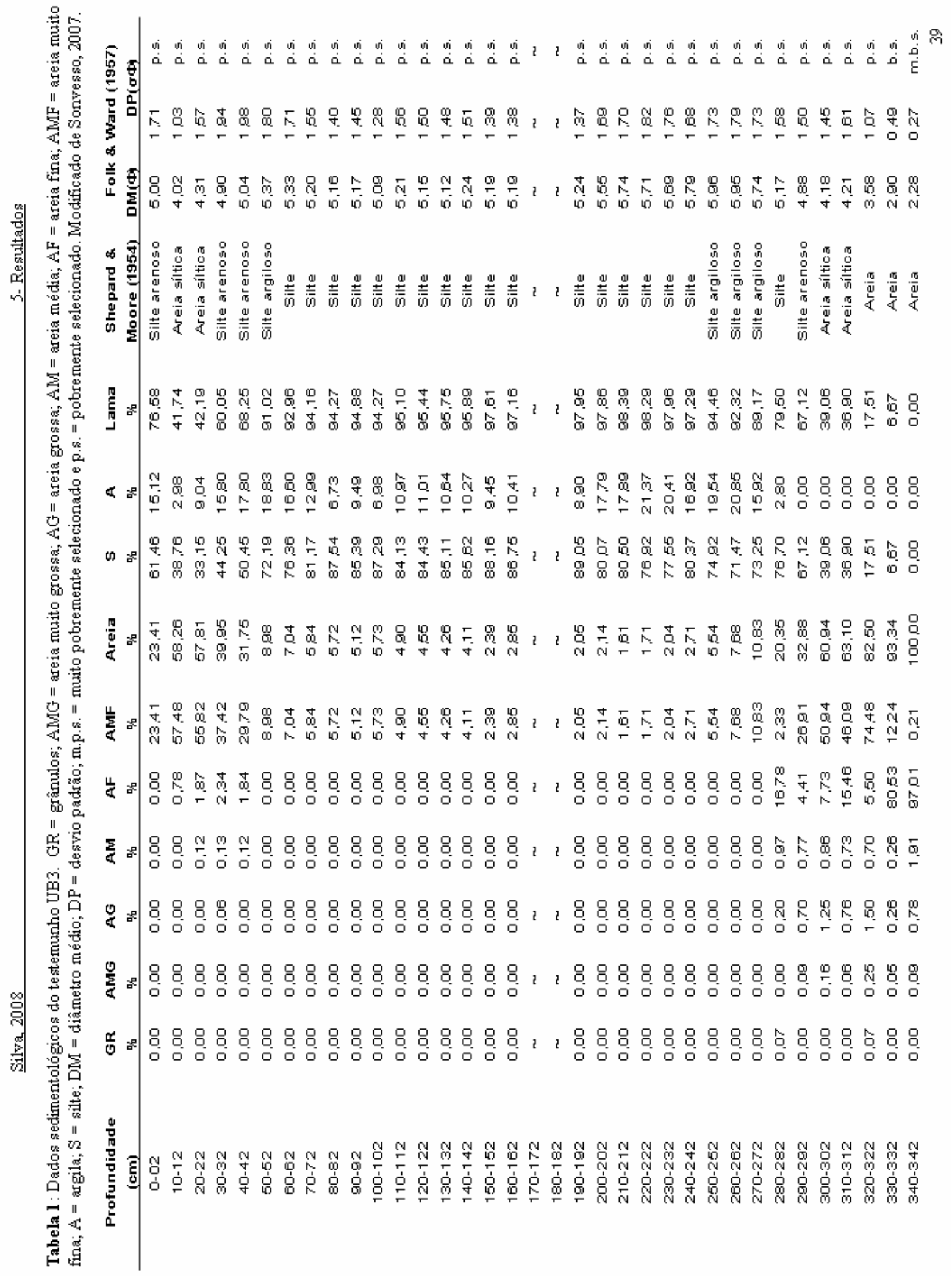


Tabela 4: Dados geoquímicos do testemunho UB3. Teor de $\mathrm{CaCO}_{3}$ - classificação sedimentológica de acordo com Larsonneur (1977, modificado por Dias, 1996); porcentagens de Carbono orgânico - $\mathrm{C}_{\text {org. }}$; Nitrogênio - $\mathrm{N}_{\text {total }}$; Enxofre - $\mathrm{S}_{\text {total }}$ e Razão C/N - Classificação segundo Bordwosky (1965, apud Yoshikazu \& Massumoto, 2001); Razão C/S - Classificação segundo Borrego et.al. (1998). $\delta^{13} \mathrm{C}$, de acordo com Waples (apud Stein 1991). Dados modificados de Sonvesso (2007)

\begin{tabular}{|c|c|c|c|c|c|c|c|c|c|c|c|}
\hline $\begin{array}{l}\text { Profundidade } \\
\text { (cm) }\end{array}$ & $\%$ & $\mathrm{JaCO}_{3}$ & $\begin{array}{c}\mathbf{C}_{\text {org. }} \\
\%\end{array}$ & $\begin{array}{c}\mathbf{N}_{\text {total }} \\
\%\end{array}$ & $\begin{array}{c}\mathrm{S}_{\text {total }} \\
\%\end{array}$ & $\mathrm{C} / \mathrm{N}$ & $\begin{array}{c}\text { Origem da } \\
\text { M. } 0 .\end{array}$ & $\mathrm{C} / \mathrm{S}$ & $\begin{array}{l}\text { Potencial de } \\
\text { oxi-redução }\end{array}$ & $\begin{array}{c}\delta^{13} \mathrm{C} \\
(\mathrm{ppm})\end{array}$ & $\begin{array}{c}\text { Origem da } \\
\text { M. } 0 .\end{array}$ \\
\hline $0-02$ & 17,500 & Litoclástico & 0,268 & 0,014 & 0,130 & 19,828 & Continental & 2,067 & Redutor & $-22,8$ & \\
\hline $10-12$ & 11,200 & Litoclástico & 0,295 & 0,013 & 0,105 & 22,680 & Continental & 2,812 & Redutor & & \\
\hline $20-22$ & 19,300 & Litoclástico & 0,537 & 0,008 & 0,105 & 67,136 & Continental & 5,093 & Oxidante & $-23,7$ & \\
\hline $30-32$ & 20,500 & Litoclástico & 0,500 & 0,005 & 0,202 & 103,977 & Continental & 2,475 & Redutor & & \\
\hline $40-42$ & 16,900 & Litoclástico & 0,433 & 0,011 & 0,187 & 39,685 & Continental & 2,316 & Redutor & $-23,6$ & \\
\hline $50-52$ & 20,250 & Litoclástico & 0,435 & 0,015 & 0,221 & 29,447 & Continental & 1,967 & Redutor & & \\
\hline $60-62$ & $\sim$ & $\sim$ & $\sim$ & $\sim$ & $\sim$ & $\sim$ & $\sim$ & $\sim$ & $\sim$ & $\sim$ & \\
\hline $70-72$ & $\sim$ & $\sim$ & $\sim$ & $\sim$ & $\sim$ & $\sim$ & $\sim$ & $\sim$ & $\sim$ & $\sim$ & \\
\hline $80-82$ & $\sim$ & $\sim$ & $\sim$ & $\sim$ & $\sim$ & $\sim$ & $\sim$ & $\sim$ & $\sim$ & $\sim$ & \\
\hline $90-92$ & $\sim$ & $\sim$ & $\sim$ & $\sim$ & $\sim$ & $\sim$ & $\sim$ & $\sim$ & $\sim$ & $\sim$ & \\
\hline $100-102$ & $\sim$ & $\sim$ & $\sim$ & $\sim$ & $\sim$ & $\sim$ & $\sim$ & $\sim$ & $\sim$ & $\sim$ & Valores \\
\hline $110-112$ & $\sim$ & $\sim$ & $\sim$ & $\sim$ & $\sim$ & $\sim$ & $\sim$ & $\sim$ & $\sim$ & $\sim$ & entre -20 e \\
\hline $120-122$ & 13,840 & Litoclástico & 1,137 & 0,070 & 0,889 & 16,142 & Continental & 1,279 & Redutor & $-23,3$ & $\begin{array}{l}-25 \text { indicam } \\
\text { plantas com }\end{array}$ \\
\hline $130-132$ & 12,000 & Litoclástico & 1,103 & 0,071 & 0,947 & 15,540 & Continental & 1,165 & Redutor & & ciclos \\
\hline $140-142$ & 14,320 & Litoclástico & 1,313 & 0,085 & 0,948 & 15,445 & Continental & 1,385 & Redutor & $-23,4$ & fotossinté- \\
\hline $150-152$ & 27,350 & Litoclástico & 0,722 & 0,055 & 0,343 & 13,013 & Mista & 2,104 & Redutor & & c4, ou seja, \\
\hline $160-162$ & 29,200 & Litoclástico & 0,671 & 0,071 & 0,336 & 9,501 & Mista & 1,998 & Redutor & $-22,8$ & M.O. de \\
\hline $170-172$ & 28,133 & Litoclástico & 0,722 & 0,047 & 0,339 & 15,351 & Continental & 2,129 & Redutor & & origens tanto \\
\hline $180-182$ & 27,200 & Litoclástico & 0,796 & 0,078 & 0,401 & 10,178 & Mista & 1,984 & Redutor & $-23,2$ & $\begin{array}{c}\text { marınha } \\
\text { quanto }\end{array}$ \\
\hline $190-192$ & 29,333 & Litoclástico & 0,884 & 0,056 & 0,283 & 15,724 & Continental & 3,125 & Oxidante & & continental. \\
\hline $200-202$ & 29,000 & Litoclástico & 0,962 & 0,061 & 0,411 & 15,732 & Continental & 2,339 & Redutor & $-23,1$ & Quanto mais \\
\hline $210-212$ & 28,800 & Litoclástico & 1,039 & 0,075 & 0,460 & 13,828 & Mista & 2,259 & Redutor & & \\
\hline $220-222$ & 28,667 & Litoclástico & 1,116 & 0,058 & 0,467 & 19,088 & Continental & 2,390 & Redutor & $-22,8$ & a tendência \\
\hline $230-232$ & 26,733 & Litoclástico & 1,194 & 0,066 & 0,555 & 18,115 & Continental & 2,152 & Redutor & & à origem \\
\hline $240-242$ & 30,933 & Litobioclástico & 1,000 & 0,085 & 0,639 & 12,894 & Mista & 1,725 & Redutor & & \\
\hline $250-252$ & 22,900 & Litoclástico & 1,000 & 0,100 & 0,931 & 12,175 & Mista & 1,306 & Redutor & $-23,2$ & \\
\hline $260-262$ & 22,350 & Litoclástico & 1,000 & 0,102 & 0,015 & 11,257 & Mista & 66,667 & Oxidante & & \\
\hline $270-272$ & 21,400 & Litoclástico & 1,000 & 0,089 & 0,706 & 13,842 & Mista & 1,747 & Redutor & $-23,1$ & \\
\hline $280-282$ & 22,200 & Litoclástico & 1,000 & 0,099 & 0,574 & 11,317 & Mista & 1,950 & Redutor & & \\
\hline $290-292$ & 29,570 & Litoclástico & 1,000 & 0,077 & 0,598 & 14,379 & Mista & 1,847 & Redutor & $-22,4$ & \\
\hline $300-302$ & 20,700 & Litoclástico & 1,000 & 0,095 & 0,504 & 11,398 & Mista & 2,153 & Redutor & & \\
\hline $310-312$ & 8,200 & Litoclástico & 0,552 & 0,047 & 0,235 & 11,791 & Mista & 2,351 & Redutor & $-22,5$ & \\
\hline $320-322$ & 4,000 & Litoclástico & 0,431 & 0,034 & 0,181 & 12,879 & Mista & 2,390 & Redutor & & \\
\hline $330-332$ & 1,300 & Litoclástico & 0,354 & 0,015 & 0,093 & 23,221 & Continental & 3,815 & Oxidante & $-22,5$ & \\
\hline $340-342$ & 2,000 & Litoclástico & 0,441 & 0,019 & 0,160 & 23,464 & Continental & 2,757 & Redutor & & \\
\hline
\end{tabular}




\section{Análise Microfaunística}

\section{Testemunho UB1}

Foram identificadas 56 espécies e 31 gêneros de foraminíferos (Tabela 5, em anexo).

A identificação dos foraminíferos em nível de espécie algumas vezes não foi possível. Nesses casos, as testas foram identificadas em nível de gênero ou, em casos de testas altamente fragmentadas, em taxa mais elevados ou como fragmentos.

\section{Densidade, Riqueza e Composição Faunística}

O testemunho UB1 apresenta valores de densidade que variam de 155 a 7.200 foraminíferos/10cc (Tabela 5, em anexo). Amostras, cujas densidades de testas foram muito superiores a 300 espécimes, foram quarteadas até 4 vezes (Tabela 5). O maior valor é observado no intervalo $62-60 \mathrm{~cm}$ (datado em $4.470 \pm 40$ anos A.P.) e, o menor, ocorre no topo do testemunho.

Os valores de densidade aumentam progressivamente da base (411 foraminíferos/10cc) até $170 \mathrm{~cm}$ (6.656 foraminíferos/10cc). De $170 \mathrm{~cm}$ (datado em $6.530 \pm 40$ anos A.P.) até $72 \mathrm{~cm}$ de profundidade, a quantidade de testas diminui para 1.236 foraminíferos/10cc (Figura 13). Particularmente no intervalo 142-140 cm (no nível rico em matéria orgânica, datado em $5.040 \pm 40$ anos A.P.), há pequeno aumento da quantidade de testas (Figura 13). Entre 72 e $62 \mathrm{~cm}$, onde ocorrem sedimentos litobioclásticos, constata-se acentuado aumento de abundância de testas (7.200 foraminíferos/10cc). De 62 a $30 \mathrm{~cm}$, os valores de densidade diminuem sensivelmente para 209 foraminíferos/10cc. De 30 a $10 \mathrm{~cm}$, os valores aumentam ligeiramente. No topo do testemunho são encontrados apenas 155 foraminíferos/10cc (Figura 13).

O número de espécies encontrado no testemunho UB1 varia de $17(82-80 \mathrm{~cm})$ a $32(192-190 \mathrm{~cm})$. Da base até $130 \mathrm{~cm}$ de profundidade, os valores de riqueza encontrados são altos (32 a 25). A partir de $130 \mathrm{~cm}$, rumo ao topo do testemunho, os valores diminuem, oscilando de 17 a 25 espécies (Figura 13). 
Ao longo de todo testemunho UB1 são encontradas espécies de testas hialinas e porcelanosas, com maior frequiência das primeiras sobre as segundas (Tabela 6). As espécies mais abundantes são Ammonia spp., Cribroelphidium spp., Bolivina pulchella, Brizalina striatula, Buliminella elegantissima, Cassidulina crassa f. media, Fursenkoina pontoni, Pseudononion atlanticum e Hopkinsina pacifica (Figura 14).

A partir da freqüência relativa, constata-se a quase ausência de espécies dominantes (i.e., taxa > 49\%). São constatadas apenas espécies subdominantes, acessórias ou raras (Figura 14).

Espécies subdominantes no testemunho UB1 são Ammonia tepida, Ammonia sp., Bolivina spp., Buliminella elegantissima, Cribroelphidium discoidale e Cribroelphidium excavatum. As Ammonias são subdominantes apenas nos 12 primeiros centímetros do testemunho. Excetuando os intervalos $162-150 \mathrm{~cm}$ e de $132-130 \mathrm{~cm}$, quando é subdominante, Bolivina spp. é gênero acessório da base até os 12 primeiros centímetros do testemunho. Buliminella elegantissima é espécie subdominante entre as profundidades de 62 a $20 \mathrm{~cm}$. Já entre 92 a $70 \mathrm{~cm}$ e entre 162 e $160 \mathrm{~cm}$ de profundidade, é rara e, nas demais profundidades, é acessória. Cribroelphidium spp. é raro nos 12 primeiros centímetros de profundidade e entre 172 e $170 \mathrm{~cm}$. É espécie dominante em 82-70 $\mathrm{cm}$ e, subdominante em 122-120 $\mathrm{cm}$. Nos demais intervalos amostrados, é espécie acessória. (Figura 14, Tabela 7, em anexo).

Brizalina striatula, Cassidulina spp., Fursenkoina pontoni, Hopkinsina pacifica, Pseudononion atlanticum e formas jovens são espécies acessórias em alguns intervalos do testemunho. As demais espécies são raras ao longo de todo o testemunho UB1 (Figura 14, Tabela 7, em anexo). 


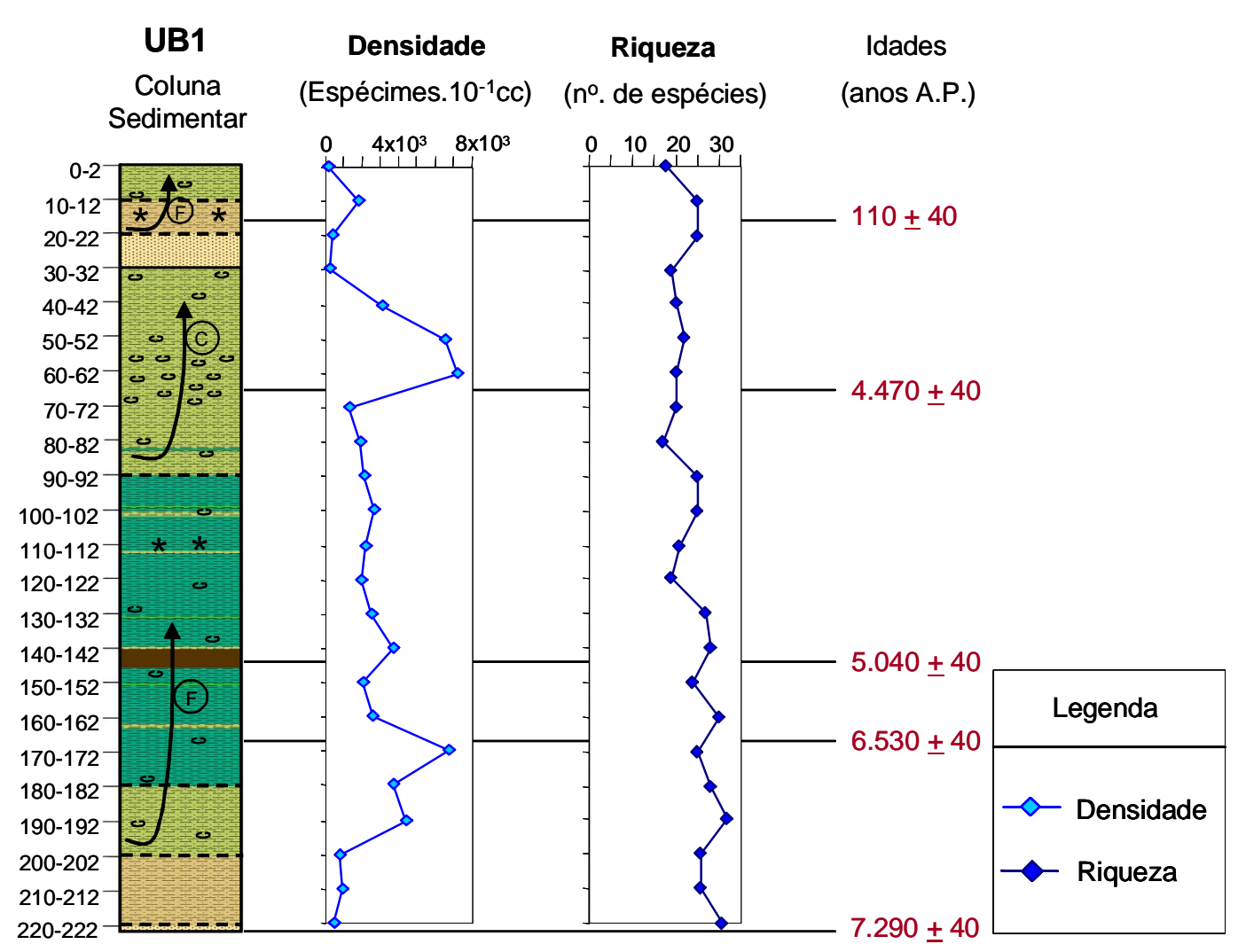

Figura 13: Gráficos de densidade e riqueza das espécies de foraminíferos encontradas no testemunho UB1. (legenda da coluna sedimentar - Figura 9) 


\section{UB1}

Coluna

A. spp. (\%)

$\begin{array}{ll}\text { Cr. spp. (\%) } & \text { B. spp. (\%) }\end{array}$

B. striatula (\%)

B. eleg. (\%)

C. spp. (\%)

F. pontoni (\%)

Idades

$0-2$
$10-12$

$10-12$
$20-22$
$30-32$

$30-32$
$40-42$

$50-52$

60-62

$70-72$
$80-82$

90-92

00-102

$110-112$

$120-122$

$140-142$

150-152

160-162

170-172

180-182

190-192

210-212

220-222
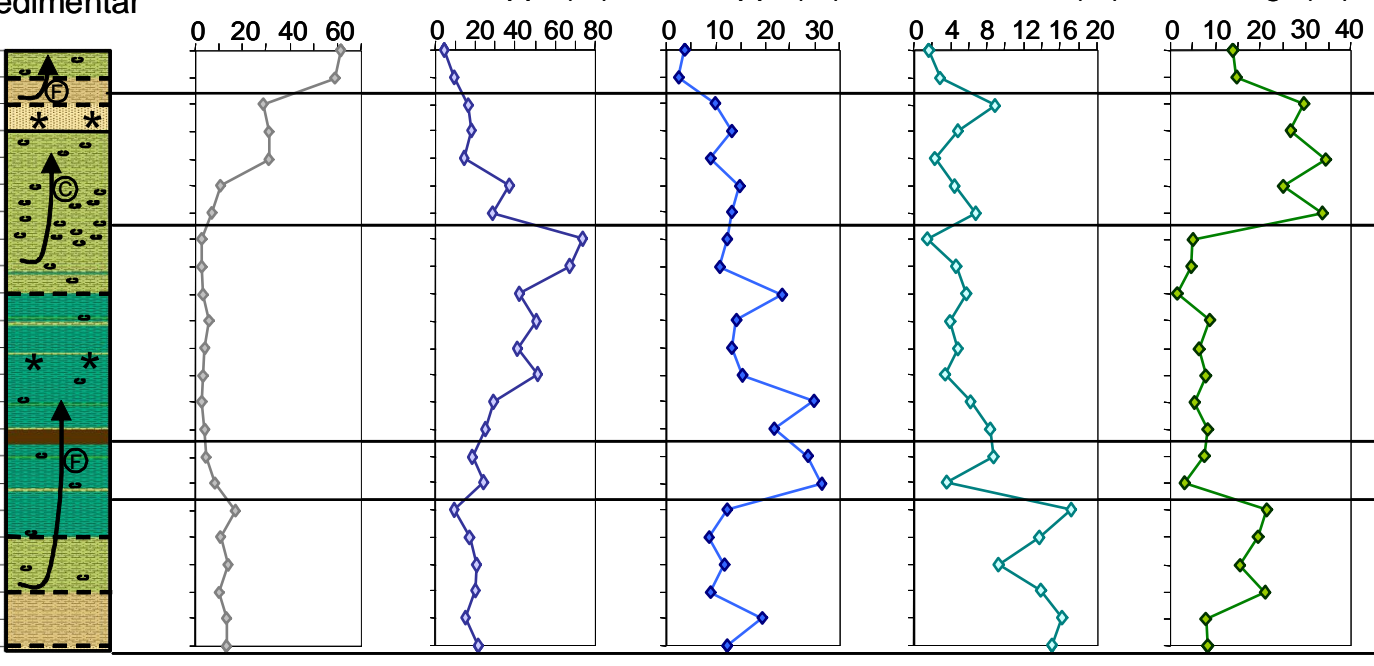

2

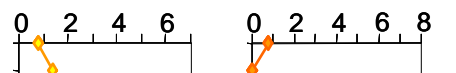

(anos A.P.)
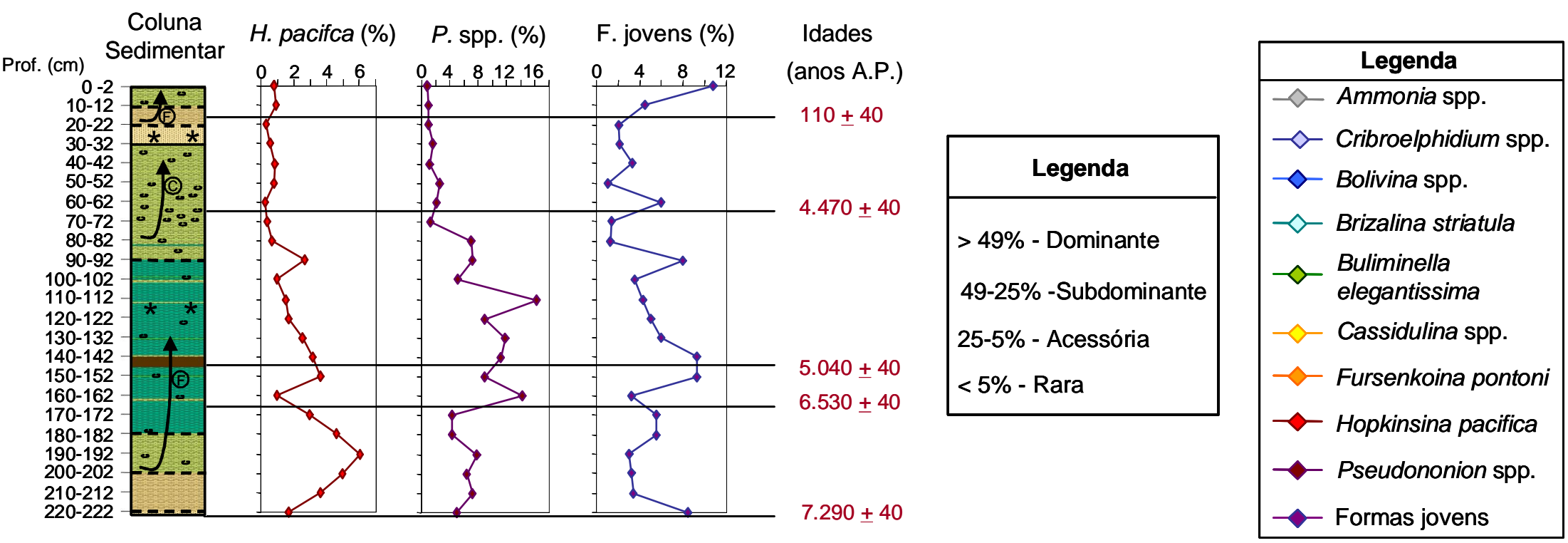

Figura 14: Gráficos de freqüência relativa dos principais gêneros e espécies do testemunho UB1 
Tabela 6: Porcentagem das espécies de foraminíferos de testas hialinas e porcelanosas encontradas ao longo do testemunho UB1

\begin{tabular}{|c|c|c|}
\hline \multicolumn{3}{|c|}{ UB 1 } \\
\hline Porfundidade (cm) & Hialinos (\%) & Porcelanosos (\%) \\
$0-2$ & 100 & 0 \\
$10-12$ & 98,13 & 1,87 \\
$20-22$ & 99,34 & 0,66 \\
$30-32$ & 99,47 & 0,53 \\
$40-42$ & 99,72 & 0,28 \\
$50-52$ & 99,49 & 0,51 \\
$60-62$ & 100 & 0 \\
$70-72$ & 100 & 0 \\
$80-82$ & 99,34 & 0,66 \\
$90-92$ & 100 & 0 \\
$100-102$ & 99,04 & 0,96 \\
$110-112$ & 100 & 0 \\
$120-122$ & 100 & 0 \\
$130-132$ & 99,74 & 0,26 \\
$140-142$ & 100 & 0 \\
$150-152$ & 99,67 & 0,33 \\
$160-162$ & 99,36 & 0,64 \\
$170-172$ & 99,75 & 0,25 \\
$180-182$ & 97,10 & 2,90 \\
$190-192$ & 99,24 & 0,76 \\
$200-202$ & 99,13 & 0,87 \\
$210-212$ & 97,84 & 2,16 \\
$220-222$ & 96,38 & 3,62 \\
\hline
\end{tabular}

\section{Principais Espécies Bioindicadoras e Microhabitats}

A longo do testemunho, constata-se a presença de espécies indicadoras das massas de água Água Costeira - AC (Ammonia spp., Cribroelphidium spp., Pararotalia cananeiaensis e Rolshauseni rolshauseni), Água Tropical - AT (Buccela peruviana, Cassidulina minuta, Cassidulina sp., Globocassidulina subglobosa, Lenticulina sp., Uvigerina peregrina e Globigerinoides ruber) e Água Central do Atlântico Sul - ACAS (Cassidulina crassa f. media). São também encontradas espécies indicadoras de ambientes ricos em matéria orgânica (Bolivina spp., Bulimina spp., Buliminella elegantissima, Brizalina striatula, Fursenkoina pontoni, Hopkinsina pacifica, Pseudononion spp. e Stainforthia concava) e de ambientes ricos em oxigênio (Cibicides spp., Discorbis williamsoni, Hanzawaia bouenana, Fissurina spp., Lagena spp., 
Neocornobina sp., Rosalina floridensis, Pyrgo spp., Quinqueloculina spp., e Triloculina laevigata) (Figura 15). As espécies do grupo da AC são as dominantes ao longo do testemunho, sendo mais abundantes entre 10 e $12 \mathrm{~cm}$ de profundidade (292 testas). Ocorrem em menor quantidade entre 150 e $152 \mathrm{~cm}$ de profundidade (69 testas).

Espécies indicadoras da ACAS são mais abundantes que espécies indicadoras da AT da base até 122-120 cm. Dessa profundidade ao topo do testemunho, espécies indicadoras de ACAS se tornam menos abundantes, apresentando quantidades muito pouco maiores que aquelas de foraminíferos indicadores da AT, com exceção dos intervalos de profundidade de $82-80 \mathrm{~cm}, 22-20 \mathrm{~cm}$ e $2-0 \mathrm{~cm}$, onde ambas as espécies indicadoras da AT e da ACAS ocorrem em quantidades equivalentes (Figura 15).

Espécies indicadoras de matéria orgânica diminuem levemente ao longo do testemunho UB1. Contudo, são mais abundantes no intervalo de 142-140 cm (331 testas), onde foi constatado nível rico em matéria orgânica (5.040 \pm 40 anos A.P.). São pouco abundantes (28 testas) no topo do testemunho (Figura 15).

Espécies indicadoras de oxigênio tendem a diminuir da base rumo ao topo de UB1, sendo mais abundantes entre 222 e $220 \mathrm{~cm}$ de profundidade. As espécies disaeróbicas são mais abundantes que as espécies óxicas, ocorrendo em maior quantidade no intervalo de 142 a $140 \mathrm{~cm}$ de profundidade; e o menor valor encontra-se entre 2 e $0 \mathrm{~cm}$ de profundidade (Figura 15).

Espécies infaunais predominam sobre espécies epifaunais da base até o intervalo de 12-10 cm. A menor abundância observada de espécies infaunais ocorre no topo do testemunho (36 testas), e sua maior quantidade (494 testas) é encontrada entre 142-140 cm de profundidade, onde é encontrado o nível de matéria orgânica (Figura 15).

Espécies pertencentes tanto à epifauna quanto à infauna são fracamente ornamentadas. Em muitos casos, a ornamentação foi desgastada por processos tafonômicos. Dentre as ornamentações observadas, as mais comuns foram suturas elevadas e limbadas ou deprimidas, pústulas e rolhas na região umbilical e costelas. Estrias e projeções alongadas, tais como espinhos, praticamente não foram observados.

As espécies disaeróbicas apresentam-se mais densamente perfuradas por poros que as espécies óxicas. A maior parte das espécies disaeróbicas é infaunal, bem como a maior parte das espécies óxicas é epifaunal. 


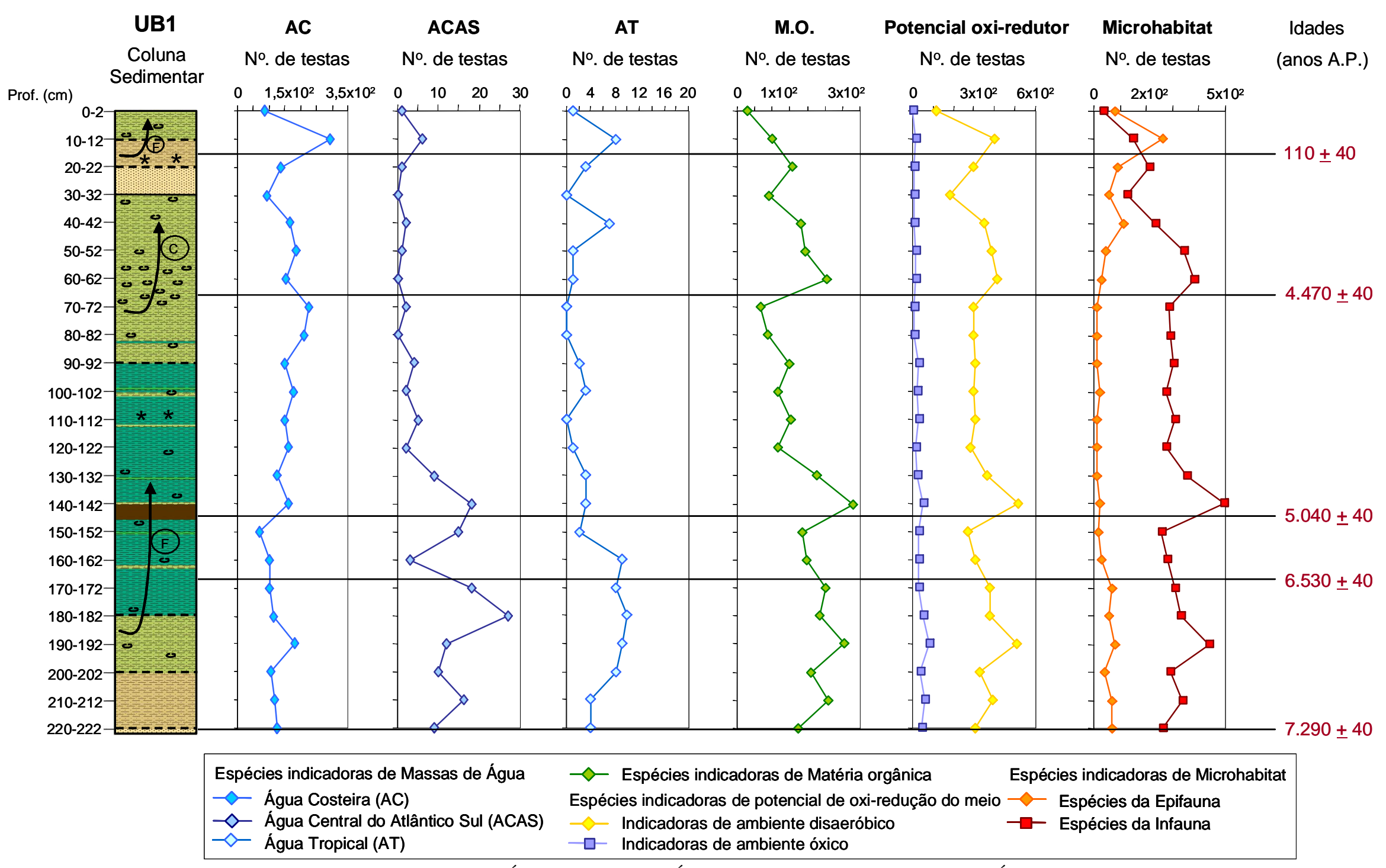

Figura 15: Gráficos de espécies indicadoras das massas de água Água Costeira (AC), Água Central do Atlântico Sul (ACAS) e Água Tropical (AT), de Matéria Orgânica (M.O.), de oxigenação do meio e de microhabitat presentes ao longo do testemunho UB1 


\section{Análise Morfométrica}

Os foraminíferos de tamanho médio (entre 125 e $250 \mu \mathrm{m}$ ) predominam ao longo do testemunho, ocorrendo em menor quantidade que as testas grandes (entre 250 e 500 $\mu \mathrm{m})$ apenas entre 70 e $82 \mathrm{~cm}$ de profundidade (Figura 16). São percentualmente mais abundantes na profundidade $172-170 \mathrm{~cm}$, onde alcançam 83,89\% da amostra analisada.

Testas pequenas $(<125 \mu \mathrm{m})$ ocorrem em menor percentagem que testas grandes entre as profundidades de $212 \mathrm{~cm}$ e $190 \mathrm{~cm} ; 162-160 \mathrm{~cm}$ e $132 \mathrm{~cm}$ e $40 \mathrm{~cm}$. Elas diminuem da base até $50 \mathrm{~cm}$ de profundidade. De 50 a $0 \mathrm{~cm}$ aumentam progressivamente, até atingir seu valor percentual máximo (43,87\% da amostra). O menor valor de testas pequenas $(0,98 \%$ da amostra $)$ ocorre a $72-70 \mathrm{~cm}$ de profundidade (Figura 16).

Testas grandes (entre 250 e $500 \mu \mathrm{m}$ ) apresentam leve decréscimo da base até $170 \mathrm{~cm}$ profundidade. Passam, então, a apresentar valores crescentes até $70 \mathrm{~cm}$, onde ocorre sua expressão máxima $(58,63 \%$ da amostra). Dessa profundidade ao topo do testemunho, os valores decrescem. O menor valor percentual de testas grandes $(3,37 \%$ da amostra) ocorre entre 172 e $170 \mathrm{~cm}$ de profundidade. As testas de tamanho macro $(>500 \mu \mathrm{m})$ ocorrem em porcentagem bastante reduzida nas amostras do testemunho (Figura 16).

\section{Análise Tafonômica}

A maioria das testas analisadas não apresenta qualquer alteração quanto à cor. Há, entretanto, presença de testas levemente preenchidas por sulfeto de ferro (douradas) e monossulfeto de ferro (preto-iridescentes), bem como de testas contendo matéria orgânica, ao longo de todo o testemunho (Figura 16). Em ambos os casos, os elementos que preencheram as testas se concentram principalmente em suturas, costelas e estrias, além de aparecer na região umbilical ou no interior da testas, quando estas se encontram fraturadas. A substituição ou impregnação da testa por sulfeto de ferro ou por matéria orgânica de forma mais intensa foi fenômeno raro no testemunho UB1.

Dentre as testas de coloração anormal, aquelas preenchidas por sulfeto de ferro (douradas) se encontram em maior porcentagem $(7,92 \%$ a $23,36 \%$ da amostra) da base do testemunho até $160 \mathrm{~cm}$ de profundidade. A partir de $150 \mathrm{~cm}$, rumo ao topo de UB1, 
as carapaças douradas e preto-iridescentes diminuem sensivelmente. As testas preenchidas por matéria orgânica ocorrem em baixas quantidades nos intervalos 222 $200 \mathrm{~cm}, 160-90 \mathrm{~cm}$ e $60-30 \mathrm{~cm}$. (Figura 16).

Se somadas, testas preenchidas por sulfeto de ferro, monossulfeto de ferro e matéria orgânica mostram-se muito mais numerosas da base até a profundidade de 132 $\mathrm{cm}$, a partir de onde seus valores decrescem consideravelmente. Testas preenchidas por óxido/hidróxido de ferro (cores acastanhadas) são bastante raras ao longo de UB1, possuindo apenas dois exemplares em diferentes profundidades desse testemunho.

Com relação à fragmentação, testas parcialmente fragmentadas e testas inteiras se encontram presentes ao longo de todo o testemunho, demonstrando-se quantitativamente mais expressivas que as testas totalmente fragmentadas, as quais, apesar de estarem presentes em todos os intervalos amostrados de UB1, possuem porcentagens bastante inferiores.

Testas inteiras predominam sobre as parcialmente fragmentadas da base do testemunho até $130 \mathrm{~cm}$ de profundidade. Entre $122 \mathrm{~cm}$ e $70 \mathrm{~cm}$ de profundidade, há alternância entre o predomínio de testas inteiras e parcialmente fragmentadas, e de 60 $\mathrm{cm}$ ao topo do testemunho, testas inteiras tornam a apresentar valores percentuais mais elevados que aqueles das parcialmente fragmentadas. Testas totalmente fragmentadas apresentam sua maior porcentagem a $2-0 \mathrm{~cm}$ de profundidade $(15,48 \%)$, onde testas inteiras e parcialmente fragmentadas aparecem em proporções semelhantes (Figura 16).

A maior porcentagem de testas inteiras ocorre entre $172-170 \mathrm{~cm}$ de profundidade $(65,39 \%$ da amostra), e a menor porcentagem, entre $72 \mathrm{~cm}$ e $70 \mathrm{~cm}$ de profundidade $(23,95 \%$ da amostra). A maior porcentagem de testas fragmentadas ocorre também entre 72 e $70 \mathrm{~cm}(76,05 \%)$, e a menor (34,61\% da amostra), entre 0 e $2 \mathrm{~cm}$ de profundidade (Figura 16).

Através das fotomicrografias obtidas por MEV, pode-se verificar que processos tafonômicos de corrosão (desgaste químico) e de bioerosão foram encontrados em testas de foraminíferos hialinos ao longo do testemunho. Nas testas de espécies porcelanosas, processos de corrosão ocorrem com freqüência, ao passo que os processos bioerosivos, apesar de presentes, são raros. Processos de abrasão (desgaste mecânico) foram detectados em menor quantidade ao longo do testemunho (Prancha 6, em anexo). 


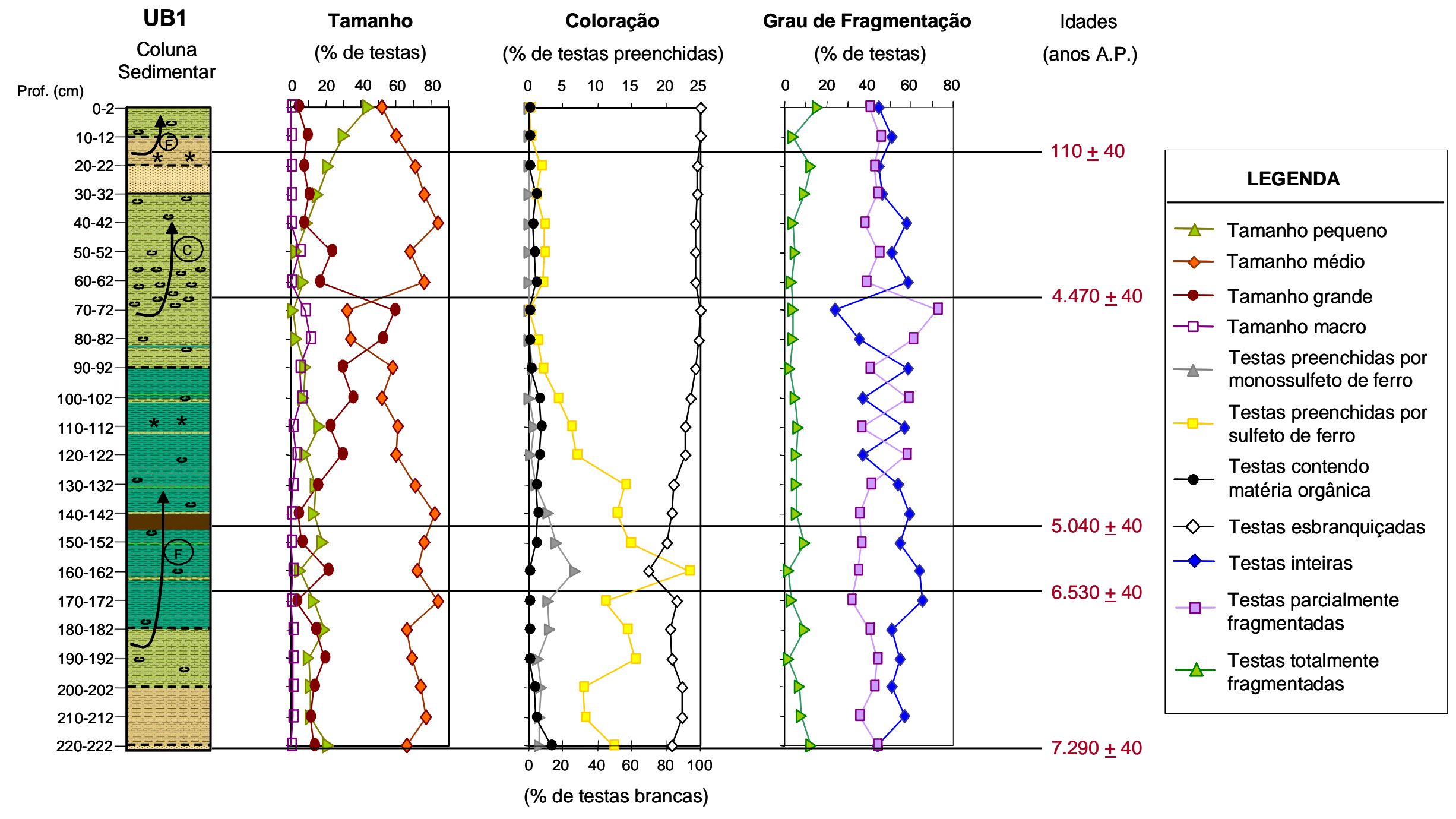

Figura 16: Gráficos de tamanho, coloração e grau de fragmentação das testas de foraminíferos das amostras do testemunho UB 1 


\section{Testemunho UB3}

Foram identificadas 72 espécies e 38 gêneros ao longo do testemunho UB3 (Tabela 8, em anexo). As testas que não puderam ser identificadas em nível de espécies foram classificadas em gêneros, taxa mais elevados ou como fragmentos.

\section{Densidade, Riqueza e Composição Faunística}

Excetuando-se a amostra do intervalo $102-100 \mathrm{~cm}$, todas as demais foram quarteadas 2 a 7 vezes (Tabela 8, em anexo). Este resultado indica grande concentração de testas na região onde o testemunho UB3 foi coletado. Os valores de densidade variam de 7 a 42.240 foraminíferos/10cc, nos intervalos 102-100 cm e 152-150 cm, respectivamente. $\mathrm{O}$ valor de densidade da maioria das amostras é sempre superior a 10.000 foraminíferos/10cc (Tabela 8 , em anexo).

Os valores de densidade do testemunho UB3 apresentam padrão serrilhado de distribuição, que tende a aumentar da base para o topo do testemunho (Figura 17). Da base até $290 \mathrm{~cm}$ de profundidade, constatam-se baixos valores de densidade, que vão de 119 a 2.092 foraminíferos/10cc. A partir $290 \mathrm{~cm}$ de profundidade até o topo do testemunho, os valores de densidade aumentam e diminuem, ainda apresentando um padrão serrilhado de distribuição.

Os valores de riqueza do testemunho UB3 variam de $2(102-100 \mathrm{~cm})$ a $47(42-40$ $\mathrm{cm}$ ) espécies de foraminíferos. De modo geral, os menores valores são encontrados na base e no intervalo 102-100 cm. Da base rumo ao topo do testemunho, esses valores tendem a aumentar, com as maiores riquezas encontradas na porção superior de UB3. O valor máximo de riqueza ocorre entre 42 e $40 \mathrm{~cm}$ de profundidade (47 espécies) (Figura 17).

Foraminíferos hilalinos e porcelanosos são abundantes ao longo de todo o testemunho UB3. Quanto aos foraminíferos aglutinantes, foi constatada apenas a espécie Miliammina fusca, distribuída em poucos intervalos desse testemunho (Tabela 9). No testemunho UB3 não ocorrem espécies dominantes (>49\%). Estão presentes apenas espécies subdominantes $(49-25 \%)$, acessórias $(24-5 \%)$ e raras $(<5 \%)$ (Tabela 10 , em anexo). 
Espécies subdominantes são: Bolivina pulchella $(342-340$ cm; 302-290 cm; 262$260 \mathrm{~cm} ; 242-240 \mathrm{~cm} ; 212-210 \mathrm{~cm}$;) Cassidulina crassa f. media $(172-170 \mathrm{~cm} ; 152-150$ m); e Hanzawaia boueana $(102-100 \mathrm{~cm})$. Bolivina pulchella é acessória nos demais intervalos, com exceção da profundidade compreendida entre 102 e 100 cm; Cassidulina crassa f. media é acessória de 292 a $0 \mathrm{~cm}$ de profundidade, no intervalo de 332 e $320 \mathrm{~cm}$ e, nos demais intervalos, é rara. Hanzawaia boueana é rara de 340 a 210 $\mathrm{cm}$; de 182 a $180 \mathrm{~cm}$ e de 152 a $0 \mathrm{~cm}$ de profundidade; nos demais intervalos é acessória (Figura 18, Tabela 10, em anexo).

Espécies acessórias são Ammonia tepida $(322-320$ cm; 302-300 cm; $12-10 \mathrm{~cm})$; Brizalina striatula $(332-330 \mathrm{~cm} ; 292-220 \mathrm{~cm} ; 192-140 \mathrm{~cm} ; 122-120 \mathrm{~cm}$ e $92-0 \mathrm{~cm})$; Bulimina marginata $(32-10 \mathrm{~cm})$; Cribroelphidium discoidale $(342-290 \mathrm{~cm} ; 252-250 \mathrm{~cm}$; $162-160 \mathrm{~cm} ; 112-110 \mathrm{~cm} ; 52-50 \mathrm{~cm}$ e 22-10 cm); Cribroelphidium excavatum (322-320 cm); Discorbis williamsoni (332-330 cm e 282-0 cm, com exceção de 102-100 cm); Fissurina laevigata $(202-200 \mathrm{~cm})$; Pararotalia cananeiaensis $(282-200 \mathrm{~cm} ; 132-130$ cm; 92-80 cm; 42-40 cm); Pseudononion atlanticum $(332-310 \mathrm{~cm} ; 292-290 \mathrm{~cm} ; 272-$ $270 \mathrm{~cm} ; 242-240 \mathrm{~cm} ; 112-110 \mathrm{~cm} ; 82-80 \mathrm{~cm} ; 62-50 \mathrm{~cm}$ e 22-20 cm); Uvigerina peregrina $(252-250 \mathrm{~cm} ; 212-210 \mathrm{~cm} ; 172-170 \mathrm{~cm} ; 152-150 \mathrm{~cm} ; 60-62 \mathrm{~cm})$ e formas jovens (342-330 cm; 312-310 cm; 272-270 cm; 232-230 cm; 110-112 cm). Nos outros intervalos essas espécies são raras (Figura 18, Tabela 10).

Todas as outras espécies presentes no testemunho UB3 são raras (Tabela 10, em anexo). 


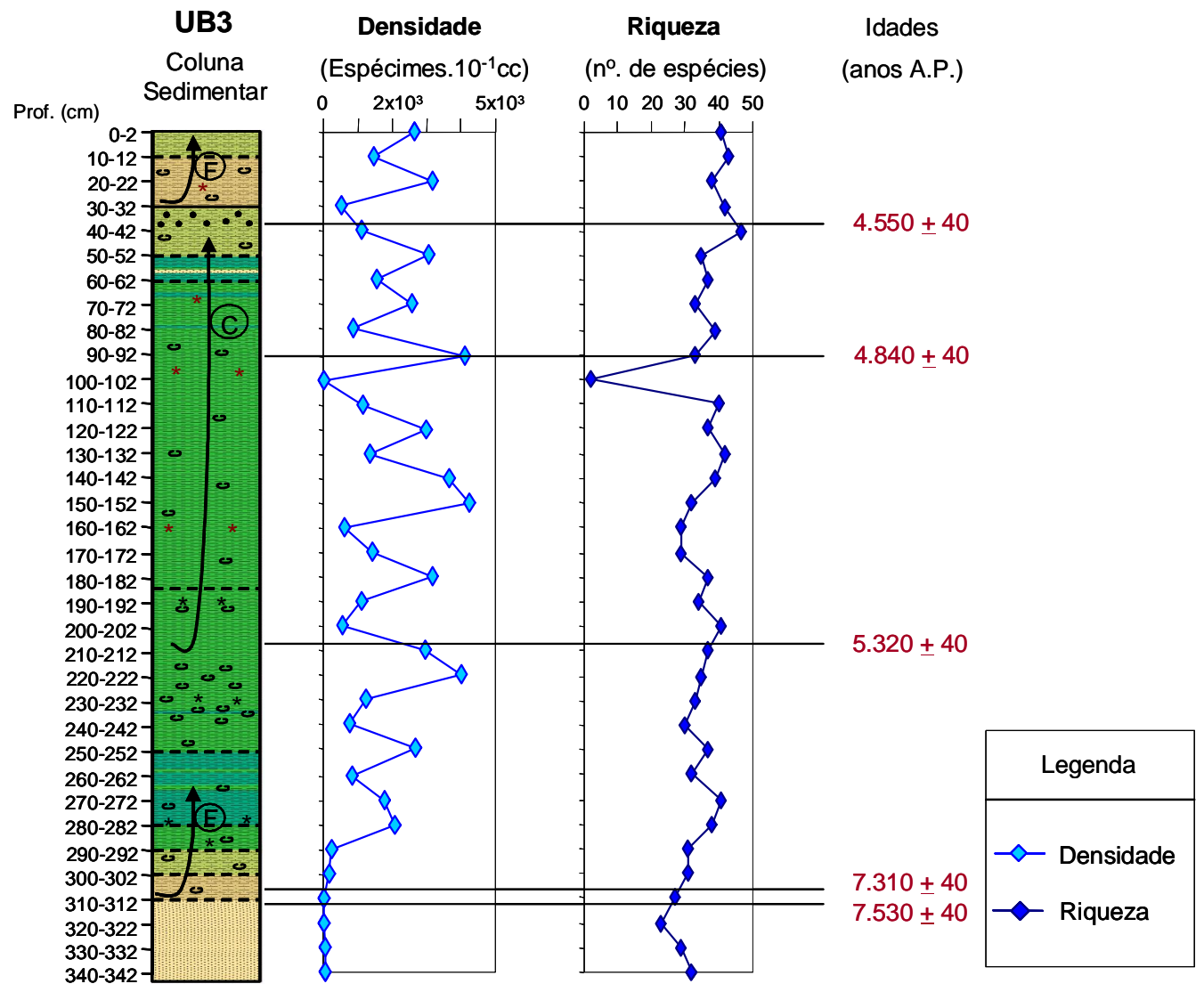

Figura 17: Gráficos de densidade e riqueza das espécies de foraminíferos encontradas no testemunho UB3 (legenda da coluna sedimentar - figura 9) 


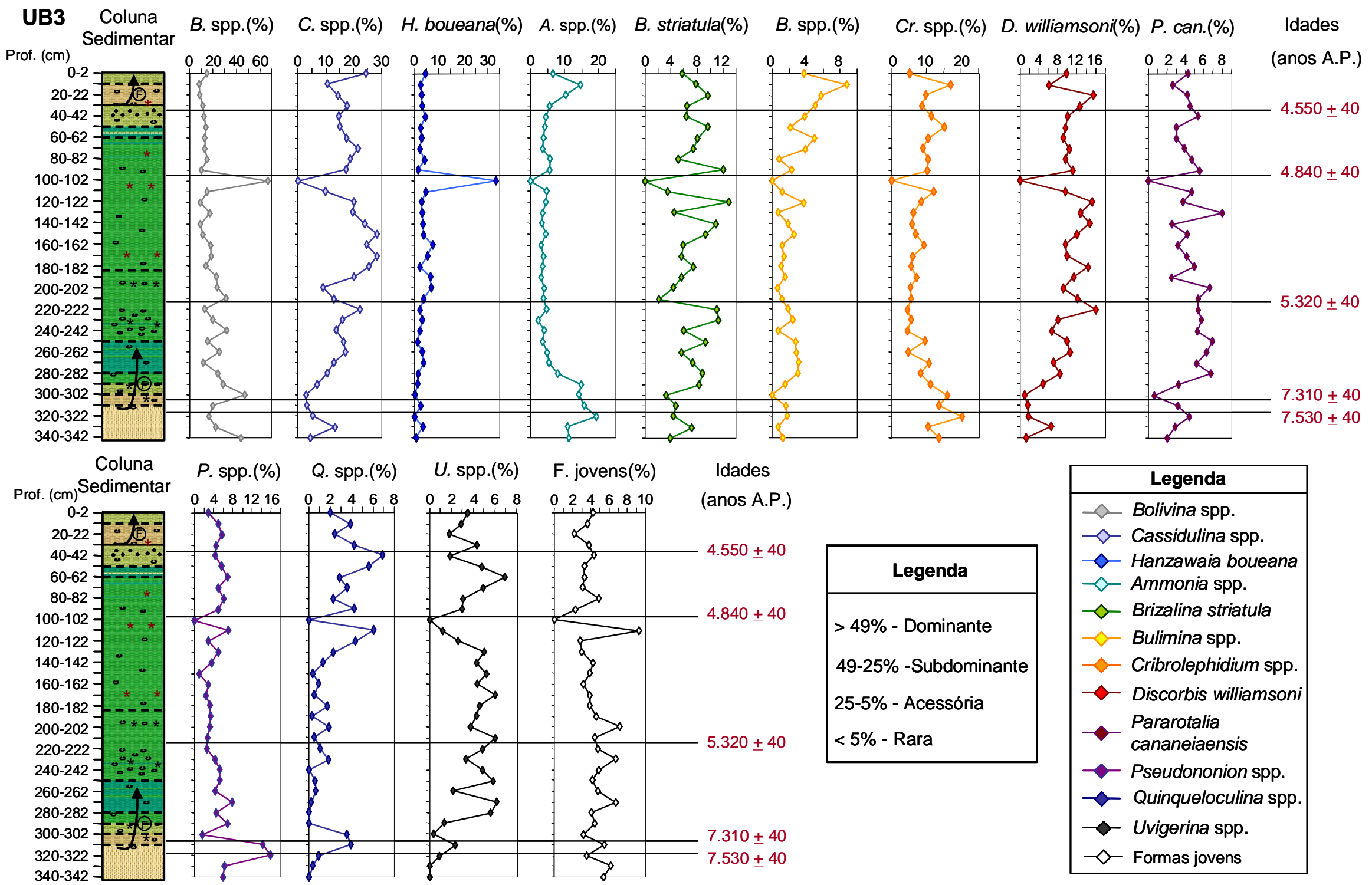

Figura 18: Gráficos de freqüência relativa dos principais gêneros e espécies do testemunho UB3 
Tabela 9: Porcentagem das espécies de foraminíferos de testas hialinas, porcelanosas e aglutinantes encontradas ao longo do testemunho UB3

\begin{tabular}{|c|c|c|c|}
\hline \multicolumn{4}{|c|}{ UB 3} \\
\hline Porfundidade (cm) & Hialinos (\%) & Porcelanosos (\%) & Aglutinantes (\%) \\
\hline $0-2$ & 97,46 & 2,54 & 0 \\
\hline $10-12$ & 95,38 & 4,62 & 0 \\
\hline $20-22$ & 97,58 & 2,42 & 0 \\
\hline $30-32$ & 95,83 & 4,17 & 0 \\
\hline $40-42$ & 92,65 & 7,20 & 0,15 \\
\hline $50-52$ & 93,96 & 6,04 & 0 \\
\hline $60-62$ & 96,75 & 3,03 & 0,22 \\
\hline $70-72$ & 95,63 & 4,37 & 0 \\
\hline $80-82$ & 97,16 & 2,84 & 0 \\
\hline $90-92$ & 94,78 & 5,22 & 0 \\
\hline $100-102$ & 100 & 0 & 0 \\
\hline $110-112$ & 91,90 & 7,81 & 0,29 \\
\hline $120-122$ & 94,53 & 5,47 & 0 \\
\hline $130-132$ & 96,25 & 3,50 & 0,25 \\
\hline $140-142$ & 97,44 & 2,38 & 0,18 \\
\hline $150-152$ & 99,36 & 0,64 & 0 \\
\hline $160-162$ & 99,13 & 0,87 & 0 \\
\hline $170-172$ & 99,52 & 0,48 & 0 \\
\hline $180-182$ & 97,83 & 2,17 & 0 \\
\hline $190-192$ & 99,69 & 0,31 & 0 \\
\hline $200-202$ & 97,18 & 2,82 & 0 \\
\hline $210-212$ & 99,08 & 0,92 & 0 \\
\hline $220-222$ & 98,64 & 1,36 & 0 \\
\hline $230-232$ & 97,27 & 2,73 & 0 \\
\hline $240-242$ & 99,77 & 0,23 & 0 \\
\hline $250-252$ & 99,19 & 0,81 & 0 \\
\hline $260-262$ & 99,35 & 0,65 & 0 \\
\hline $270-272$ & 99,62 & 0,38 & 0 \\
\hline $280-282$ & 100 & 0 & 0 \\
\hline $290-292$ & 100 & 0 & 0 \\
\hline $300-302$ & 94,57 & 5,43 & 0 \\
\hline $310-312$ & 96,07 & 3,93 & 0 \\
\hline $320-322$ & 99,12 & 0,88 & 0 \\
\hline $330-332$ & 98,92 & 1,08 & 0 \\
\hline $340-342$ & 98,98 & 1,02 & 0 \\
\hline
\end{tabular}

\section{Principais Espécies Bioindicadoras e Microhabitat}

Foram encontradas ao longo de UB3 espécies indicadoras das massas de Água Costeira (Ammonia spp., Cribroelphidium spp, Pararotalia cananeiaensis e Rolshauseni rolshauseni), Água Tropical (Buccela peruviana, Cassidulina minuta, Cassidulina sp., Globocassidulina subglobosa, Lenticulina sp., Uvigerina peregrina e Globigerinoides ruber) e Água Central do Atlântico Sul (Cassidulina crassa f. media e Uvigerina bifurcata). Também foram encontradas espécies indicadoras de ambientes 
ricos em matéria orgânica (Bolivina spp., Bulimina spp., Buliminella elegantissima, Brizalina striatula, Fursenkoina pontoni, Hopkinsina pacifica, Pseudononion spp. e Stainforthia concava) e de ambientes ricos em oxigênio (Cancris sagra, Cibicides spp., Discorbis williamsoni, Eponides cf. repandus, Hanzawaia bouenana, Lobatula lobatula, Fissurina spp., Guttulina plancii, Lagena spp., Oolina hexagona, Neocornobina sp., Rosalina floridensis, Milliamina fusca, Pyrgo spp., Quinqueloculina spp. e Spiroloculina sp.) (Figura 19).

Entre as profundidades de 342 e $270 \mathrm{~cm}, 52$ e $40 \mathrm{~cm}$ e 22 e $10 \mathrm{~cm}$, as espécies do grupo da Água Costeira (AC) predominam sobre espécies de Água Tropical (AT) e Água Central do Atlântico Sul (ACAS); (Figura 19).

Entre $222 \mathrm{~cm}$ e $220 \mathrm{~cm}$ de profundidade e entre $192 \mathrm{~cm} \mathrm{e} 120 \mathrm{~cm}$ de profundidade, espécies indicadoras da ACAS predominam sobre espécies indicadoras da AC, com valor máximo nos intervalos de 222-220 cm e de $142-140 \mathrm{~cm}$ (128 foraminíferos) e mínimo (0 foraminíferos) no intervalo de 100-102 cm. Espécies indicadoras da AT são mais abundantes que as indicadoras da ACAS somente no intervalo de 322 a $300 \mathrm{~cm}$ (Figura 19).

Espécies indicadoras de matéria orgânica ocorrem em maior quantidade entre $282 \mathrm{~cm}$ e $220 \mathrm{~cm}$ de profundidade e na parte superior do testemunho UB3. O valor máximo ocorre no intervalo de 282-280 cm (255 testas) de profundidade e o mínimo (2 testas), entre 102 e $100 \mathrm{~cm}$ em UB3 (Figura 19).

As espécies indicadoras de oxigênio são pouco abundantes no testemunho UB3. Elas tendem a aumentar sua concentração da base rumo ao topo do testemunho. Atingem seu valor máximo entre 42 e $40 \mathrm{~cm}$ de profundidade (176 testas) e, então, tornam a diminuir rumo ao topo do testemunho. $\mathrm{O}$ menor valor de espécies óxicas ( 1 testa) ocorre entre 102 e $100 \mathrm{~cm}$ (Figura 19).

As espécies disaeróbicas são percentualmente mais abundantes ao longo de UB3. Elas apresentam valores entre 450 e 98 espécies ao longo de todo o testemunho, com exceção do intervalo de profundidade de $102-100 \mathrm{~cm}$ (2 testas). Seu maior valor se encontra entre 282 e $280 \mathrm{~cm}$ de profundidade (453 testas), e o menor valor ocorre entre 102 e $100 \mathrm{~cm}$ de profundidade (2 testas) (Figura 19).

Espécies infaunais predominam ao longo de todo o testemunho, tendo sido observada maior abundância (412 testas) entre 282 e $280 \mathrm{~cm}$ de profundidade, e com 
menor abundância ( 2 testas) entre 100 e $102 \mathrm{~cm}$ de profundidade. O padrão de espécies epifaunais apresenta leve aumento rumo ao topo de UB3. A maior abundância de espécies epifaunais (228 testas) ocorre entre as profundidades de 42 e $40 \mathrm{~cm}$. Sua menor quantidade (1 testa) ocorre entre 102 e $100 \mathrm{~cm}$ de profundidade (Figura 19).

A ornamentação das espécies infaunais e epifaunais é fraca ou inexistente. Como observado no testemunho UB1, as espécies disaeróbicas são mais densamente perfuradas por poros que espécies óxicas. 


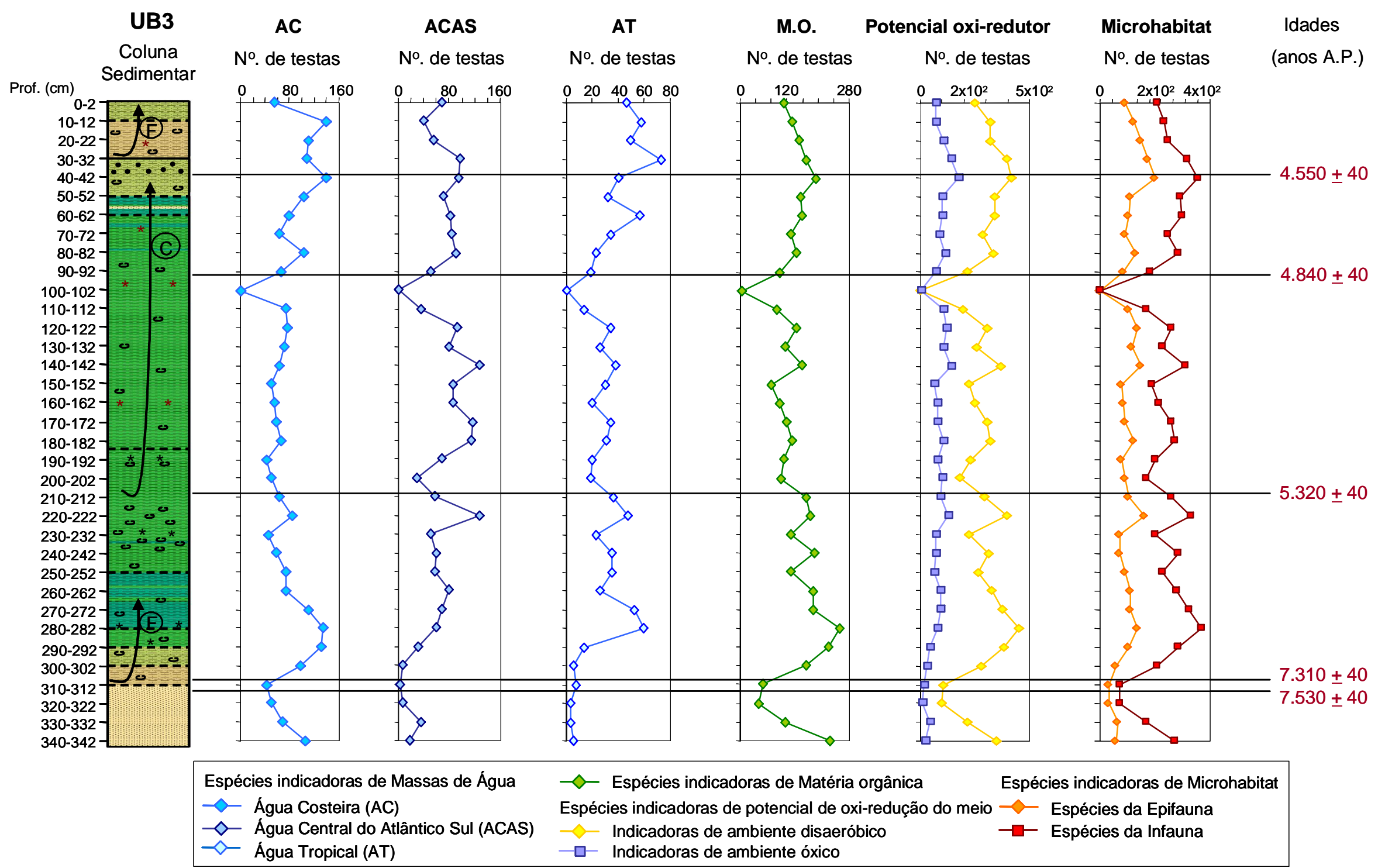

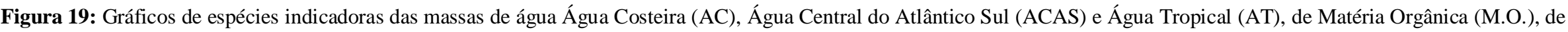
oxigenação do meio e de microhabitat presentes ao longo do testemunho UB3 


\section{Análise Morfométrica}

As testas de tamanho médio $(125-250 \mu \mathrm{m})$ predominam ao longo do testemunho UB3, com exceção dos intervalos de profundidade entre $162-160 \mathrm{~cm}, 102-100 \mathrm{~cm}$ e 82 e $80 \mathrm{~cm}$, onde testas pequenas $(<125 \mu \mathrm{m})$ têm maior porcentagem. Foraminíferos médios apresentam valores percentuais que crescem da base até $312-310 \mathrm{~cm}$ de profundidade, a partir de onde diminuem até $222-220 \mathrm{~cm}$. Eles aumentam rapidamente entre 222 e 212 cm e, então, tornam a diminuir até $162-160 \mathrm{~cm}$. A partir dessa profundidade, suas porcentagens aumentam até 122-120 cm. Sofrem então rápida diminuição até $102-100 \mathrm{~cm}$ de profundidade, onde atingem seu valor mínimo (28,57\% da amostra). De 102 a $90 \mathrm{~cm}$, têm aumento considerável e, daí até $82-80 \mathrm{~cm}$, tornam a diminuir. Dessa profundidade até $40 \mathrm{~cm}$ de profundidade, os valores percentuais das testas médias tornam a crescer e, a partir de então, decrescem até $22-20 \mathrm{~cm}$ e então aumentam ligeiramente até o topo do testemunho. Seu maior valor percentual ocorre a $312-310 \mathrm{~cm}(82,47 \%$ da amostra).

Testas de tamanho pequeno apresentam valores crescentes da base do testemunho até a profundidade de $222-220 \mathrm{~cm}$. Decrescem rapidamente nos 10 centímetros seguintes e então tornam a aumentar até 162-160 cm. Diminuem dessa profundidade até $122-120 \mathrm{~cm}$ e então aumentam rapidamente até $102-100 \mathrm{~cm}$, decrescendo em seguida rumo ao topo de UB3. Seu maior valor ocorre a 102-100 cm $(71,43 \%$ da amostra analisada), e o menor valor ocorre a $322-320 \mathrm{~cm}$ de profundidade (5,04\% da amostra) (Figura 20).

Testas grandes $(250-500 \mu \mathrm{m})$ predominam sobre testas pequenas apenas nos intervalos de 322 a $300 \mathrm{~cm}, 52$ a $40 \mathrm{~cm}$ e 12 a $10 \mathrm{~cm}$ de profundidade. Elas apresentam ligeiro decréscimo da base até 262-260 $\mathrm{cm}$ de profundidade, a partir de onde demonstram pequeno aumento de seus valores rumo ao topo do testemunho. Seu maior valor $(25,21 \%)$ é alcançado entre 322 e $320 \mathrm{~cm}$ (Figura 20). Testas de tamanho macro (> $500 \mu \mathrm{m}$ ) ocorrem em porcentagem bastante reduzida nas amostras do testemunho UB3 (Figura 20).

\section{Análise Tafonômica}

O testemunho UB3 demonstrou maior porcentagem de testas normais, isto é, sem alteração da cor. Entretanto há presença de testas preenchidas por sulfeto de ferro 
(douradas) e por matéria orgânica. Em menor porcentagem, ocorrem testas preenchidas por monossulfeto de ferro (preto-iridescentes). Testas preenchidas por óxido/hidróxido de ferro (acastanhadas) ocorrem em percentagens muito baixas, tendo sido encontrados apenas 15 espécimes, em diferentes intervalos desse testemunho (Figura 20).

Testas com coloração normal aumentam gradativamente da base do testemunho até a profundidade de $252-250 \mathrm{~cm}$, quando seus valores passam a diminuir até 112-110 $\mathrm{cm}$. A partir dessa profundidade, sua quantidade aumenta levemente até $192-190 \mathrm{~cm} \mathrm{e}$ diminui até $112-110 \mathrm{~cm}$. A porcentagem dos $12 \mathrm{~cm}$ seguintes, entre 110-102 cm, é maior (100\% da amostra, 7 testas) e, então, diminui até $62-60 \mathrm{~cm}$, a partir de onde aumentam até 22-20 cm e diminuem daí ao topo do testemunho (figura 20).

Dentre as testas com coloração anormal, aquelas preenchidas por sulfeto de ferro (douradas) são as que ocorrem em maiores percentagens ao longo do testemunho. Elas tendem a diminuir até $252-250 \mathrm{~cm}$ e então aumentam em direção ao topo de UB3, até a profundidade de $62-60 \mathrm{~cm}$, onde têm seu valor máximo $(20,21 \%)$. A partir daí, decrescem até $22-20 \mathrm{~cm}$ de profundidade. Para os vinte últimos centímetros, seus valores tornam-se novamente crescentes (Figura 20).

As curvas de testas preenchidas por matéria orgânica e monossulfeto de ferro apresentam o mesmo padrão ao longo desse testemunho, possuindo baixa percentagem e sofrendo ligeiro aumento da base até $180 \mathrm{~cm}$, de 82 a $60 \mathrm{~cm}$ e nos últimos $42 \mathrm{~cm}$ de UB3 (Figura 20).

Se somadas, testas preenchidas por sulfeto de ferro, matéria orgânica e monossulfeto de ferro mostram valores levemente decrescentes da base até $252-250 \mathrm{~cm}$, a partir de onde aumentam até $62 \mathrm{~cm}$. Dessa profundidade em diante, seus valores percentuais passam a diminuir até $22-20 \mathrm{~cm}$. Nos primeiros $20 \mathrm{~cm}$ do testemunho as porcentagens de testas preenchidas aumentam (Figura 20).

Com relação à fragmentação, testas inteiras e parcialmente fragmentadas aparecem em maior quantidade ao longo de todo o testemunho se comparadas às testas totalmente fragmentadas, cujos valores percentuais são bastante baixos, com exceção do intervalo de profundidade de $102-100 \mathrm{~cm}$, onde esses valores somam 57,14\% da amostra.

Testas parcialmente fragmentadas aparecem em maior quantidade nos intervalos de profundidade de $342-340 \mathrm{~cm}, 322-310 \mathrm{~cm}, 292-270 \mathrm{~cm}$ e $12-10 \mathrm{~cm}$. Nos demais 
intervalos de profundidade, a predominância passa a ser daquelas que se apresentam inteiras. Testas totalmente fragmentadas, apesar de serem pouco abundantes, tendem a aumentar da base até $122 \mathrm{~cm}$ de profundidade, a partir de onde sua quantidade diminui rumo ao topo do testemunho (Figura 20).

Por meio de fotomicrografias do MEV, foram verificados processos tafonômicos de corrosão (desgaste químico) e de bioerosão (desgaste bioquímico) em testas de foraminíferos hialinos. Nas testas de espécies porcelanosas, processos de corrosão ocorrem com freqüência, ao passo que os processos bioerosivos, apesar de presentes, são raros. Processos tafonômicos de abrasão (desgaste mecânico) ocorreram em quantidades muito baixas ao longo do testemunho (Prancha 7, em anexo). 


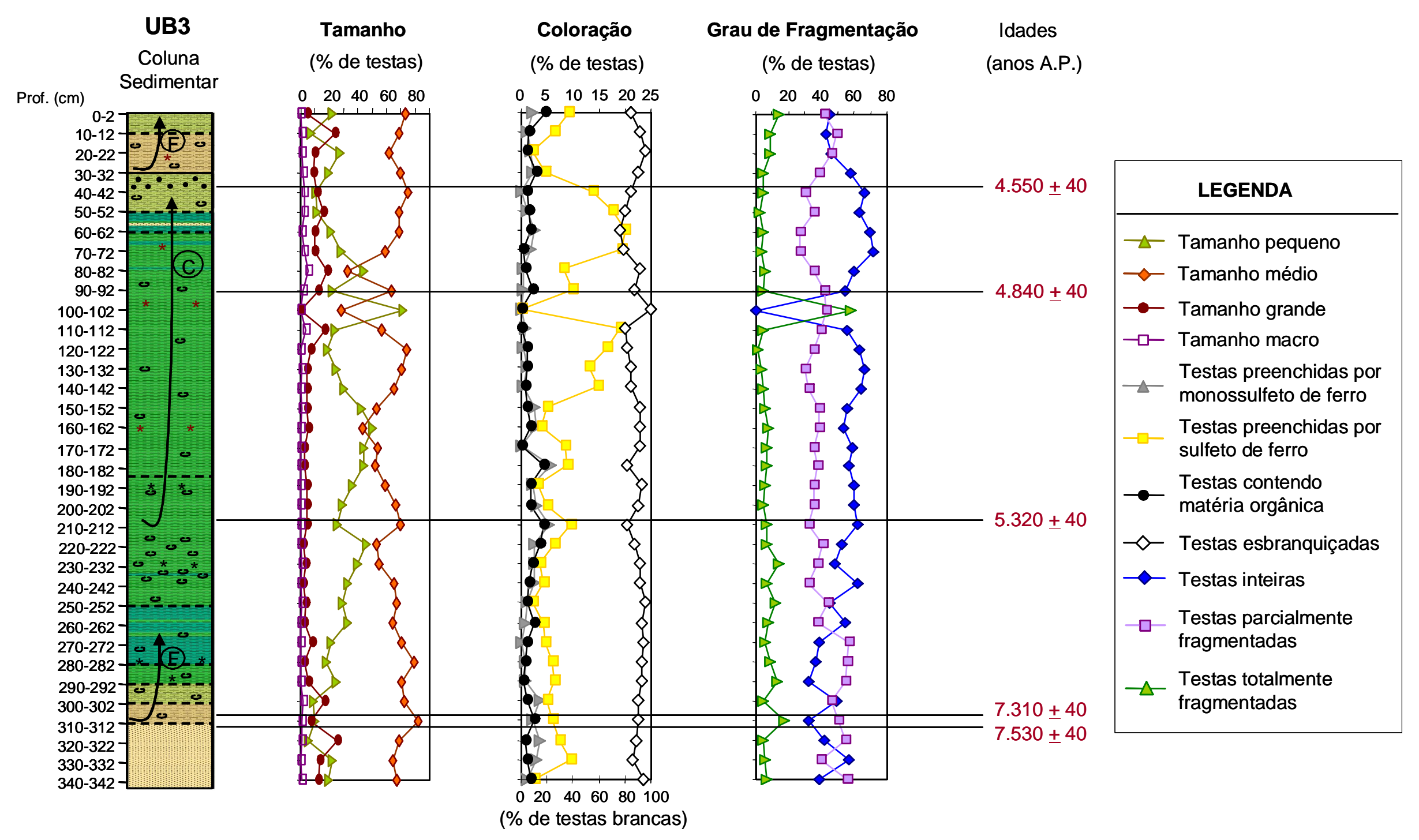

Figura 20: Gráficos de tamanho das testas, coloração e grau de fragmentação das testas de foraminíferos das amostras do testemunho UB3 


\section{Correlação Entre Dados Bióticos e Abióticos}

Os resultados obtidos no cálculo do índice Ammonia-Elphidium (Índice A-E) para as amostras dos testemunhos UB1 e UB3 estão indicadas nos gráficos da figura 21. Nota-se, por eles, que o padrão de hipoxia tanto na Enseada do Flamengo quanto na Enseada da Fortaleza são baixos ao longo dos testemunhos até $52 \mathrm{~cm}$ de profundidade em UB1 e também até $52 \mathrm{~cm}$ de profundidade em UB3. A partir dessas profundidades, as enseadas passam a apresentar um quadro de maior hipoxia, com valores crescentes para o Índice A-E, que chega a somar $100 \%$ nas duas enseadas entre 2 e $0 \mathrm{~cm}$ de profundidade (Figura 21).

Há picos de hipoxia nas profundidades compreendidas entre os intervalos de 112 a $110 \mathrm{~cm}$ no testemunho UB1, e nas profundidades compreendidas entre 302 e $300 \mathrm{~cm}$ e entre 132 e $130 \mathrm{~cm}$ no testemunho UB3. Pode-se notar, também, que a partir da ascensão do quadro de hipoxia em ambos os testemunhos a $52-50 \mathrm{~cm}$ de profundidade, houve um primeiro aumento entre as profundidades de 42 e $40 \mathrm{~cm}$, seguida por diminuição no intervalo seguinte amostrado, entre 32 e $30 \mathrm{~cm}$ de profundidade e, então, o grau de hipoxia dos sistemas deposicionais do Saco da Ribeira e da Praia do Lázaro tornou a se elevar até o topo de ambos os testemunhos, com aumento muito mais brusco na Enseada da Fortaleza que na Enseada do Flamengo, cuja ampliação dos valores percentuais foi mais gradual (Figura 21). 

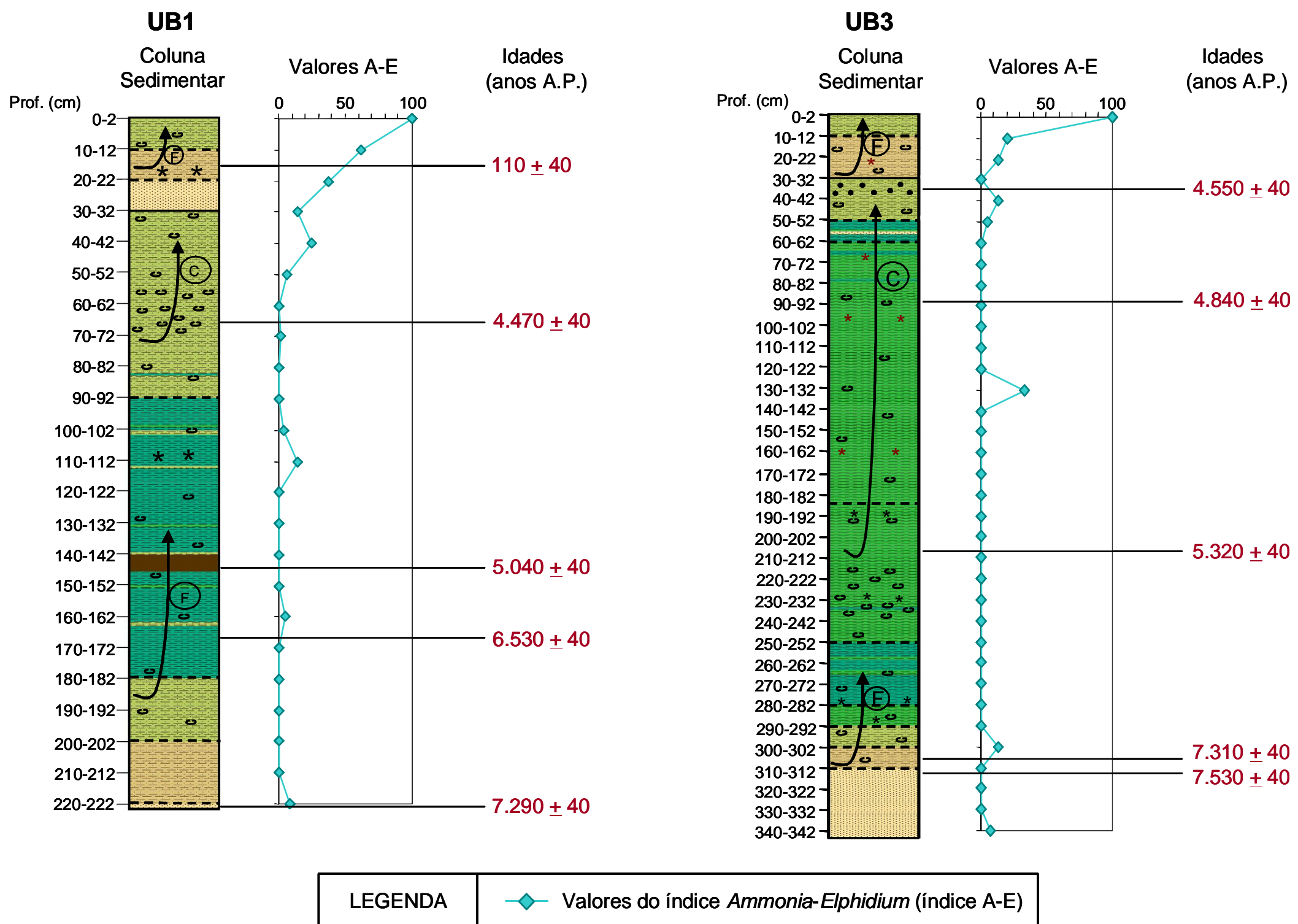

Figura 21: Gráficos do índice A-E (Ammonia - Elphidium) obtidos para os testemunhos UB1 e UB3 


\section{Análise de Correlação Canônica (ACC)}

Foram testadas as correlações existentes entre 16 variáveis ambientais com as distribuições 37 espécies de foraminíferos pertencentes aos dois testemunhos. O mesmo procedimento foi adotado em relação às amostras dos testemunhos, como uma forma de se avaliar quais foram os principais parâmetros ambientais que influenciaram as associações de foraminíferos das enseadas do Flamengo e da Fortaleza através do tempo geológico.

Ao se analisar as espécies e amostras dos dois testemunhos, a ACC correlacionou significativamente seis variáveis ambientais (porcentagem de silte - \% silte, porcentagem de argila - \% argila, porcentagem de enxofre - \% S, porcentagem de carbono orgânico - \% $\mathrm{C}$, porcentagem de carbonato de cálcio - $\% \mathrm{CaCO}_{3}$ e razão $\mathrm{C} / \mathrm{N}$ ) à abundância das espécies mais representativas de 50 amostras dos dois testemunhos e, através delas, procedeu à ordenação de amostras e espécies de UB1 e de UB3. As amostras que não possuíam dados abióticos foram descartadas.

As figuras 22 e 23 ilustram os biplots das amostras e das espécies dos dois testemunhos ao longo dos dois primeiros eixos da ACC, e também os seis vetores representativos das variáveis ambientais utilizadas para a correlação.

Os autovalores para os quatro primeiros eixos foram $0.183,0.017,0.016$ e 0.010 (Tabela 11). Os comprimentos dos vetores indicam que os principais fatores ambientais que influenciaram as associações de foraminíferos de UB1 e UB3 são as porcentagens de argila e silte, seguidos pela razão $\mathrm{C} / \mathrm{N}$ e \% S. Secundariamente, as associações de foraminíferos sofrem influência das porcentagens de $\mathrm{C}$ e $\mathrm{CaCO}_{3}$.

As posições dos vetores indicam que o primeiro eixo (autovalor 0.183) é gradiente ambiental que reflete ambiente deposicional que varia de ambiente com altas porcentagens de argila e de $\mathrm{CaCO}_{3}$ e baixas porcentagens de $\mathrm{C}$ e silte, a ambiente com altas porcentagens de silte e $\mathrm{C}$ e baixas porcentagens de argila e $\mathrm{CaCO}_{3}$.

Já o segundo eixo (autovalor 0.017) indica ambiente deposicional que varia de ambiente com alta \% S e características de matéria orgânica mais continental a ambiente com tendências de matéria orgânica mais marinha e com baixas \% S.

Observando-se as amostras, pode-se verificar que essas se correlacionam principalmente com o primeiro eixo, com exceção das amostras 46 e 47 
(correspondentes às profundidades de 312 a $300 \mathrm{~cm}$ ), que demonstram maior correlação com o segundo eixo (Figura 22). Nota-se, também, que enquanto as amostras de UB1 se agrupam à esquerda do biplot, a maior parte das amostras de UB3 está concentrada do lado oposto, apesar das amostras da base desse testemunho (46, 47, 48, 49 e 50, correspondendo à profundidade compreendida entre 340 e $300 \mathrm{~cm}$ ) se concentrarem próximas às amostras de UB1 (Figura 22)

A maioria das espécies se correlaciona principalmente ao primeiro eixo, mas Neocornubina sp., Quinqueloculina sp., Globocassidulina subglobosa, Bolivina compacta e Ammonia sp. se correlacionam principalmente com o segundo eixo (Figura 23). As espécies identificadas são marinhas, calcárias hialinas ou porcelanosas, de plataforma interna a externa.

Tabela 11: Tabela de autovalores dos testemunhos UB1 e UB3

\begin{tabular}{lccccc|}
\hline Eixos & $\mathbf{1}$ & $\mathbf{2}$ & $\mathbf{3}$ & $\mathbf{4}$ & Total de Inércia \\
\hline Autovalores & 0,183 & 0,017 & 0,016 & 0,01 & 0,452 \\
Correlação entre espécies-ambientes & 0,965 & 0,811 & 0,686 & 0,718 & \\
& & & & & \\
\% da Variância Cumulativa & & & & & \\
dos dados das espécies & 40,5 & 44,2 & 47,7 & 49,8 & \\
das relações entre espécies e ambiente & 78,2 & 85,2 & 91,9 & 96 & \\
\hline
\end{tabular}




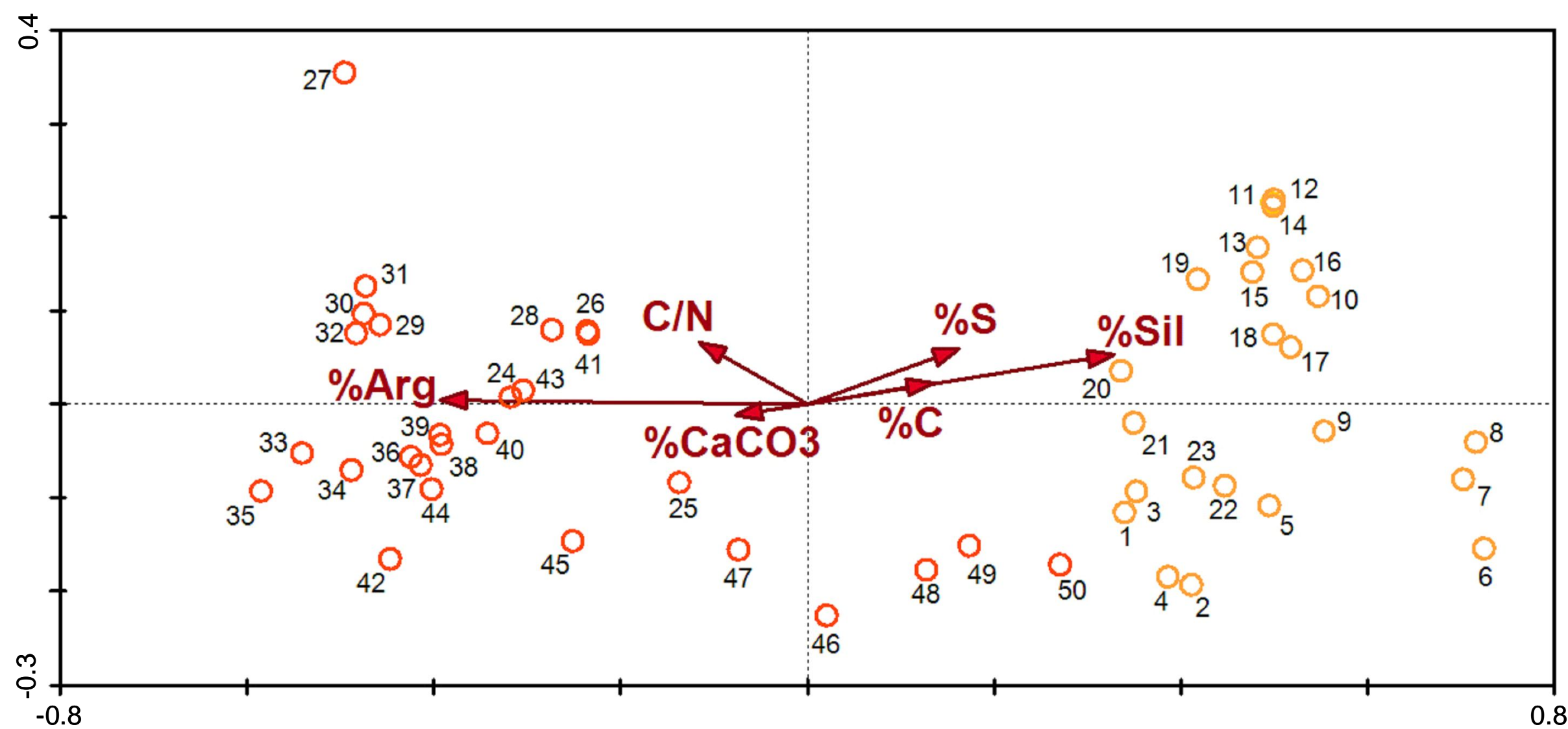

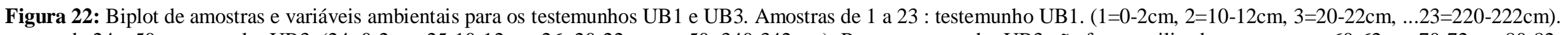

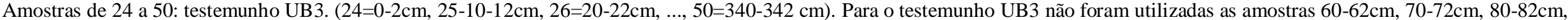

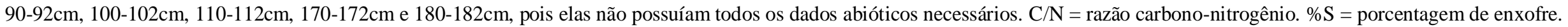
$\% \mathrm{C}=$ porcentagem de carbono. $\% \mathrm{CaCO}_{3}=$ porcentagem carbonato de cálcio. $\% \mathrm{Arg}=$ porcentagem de argila. $\%$ Sil $=$ porcentagem de silte 


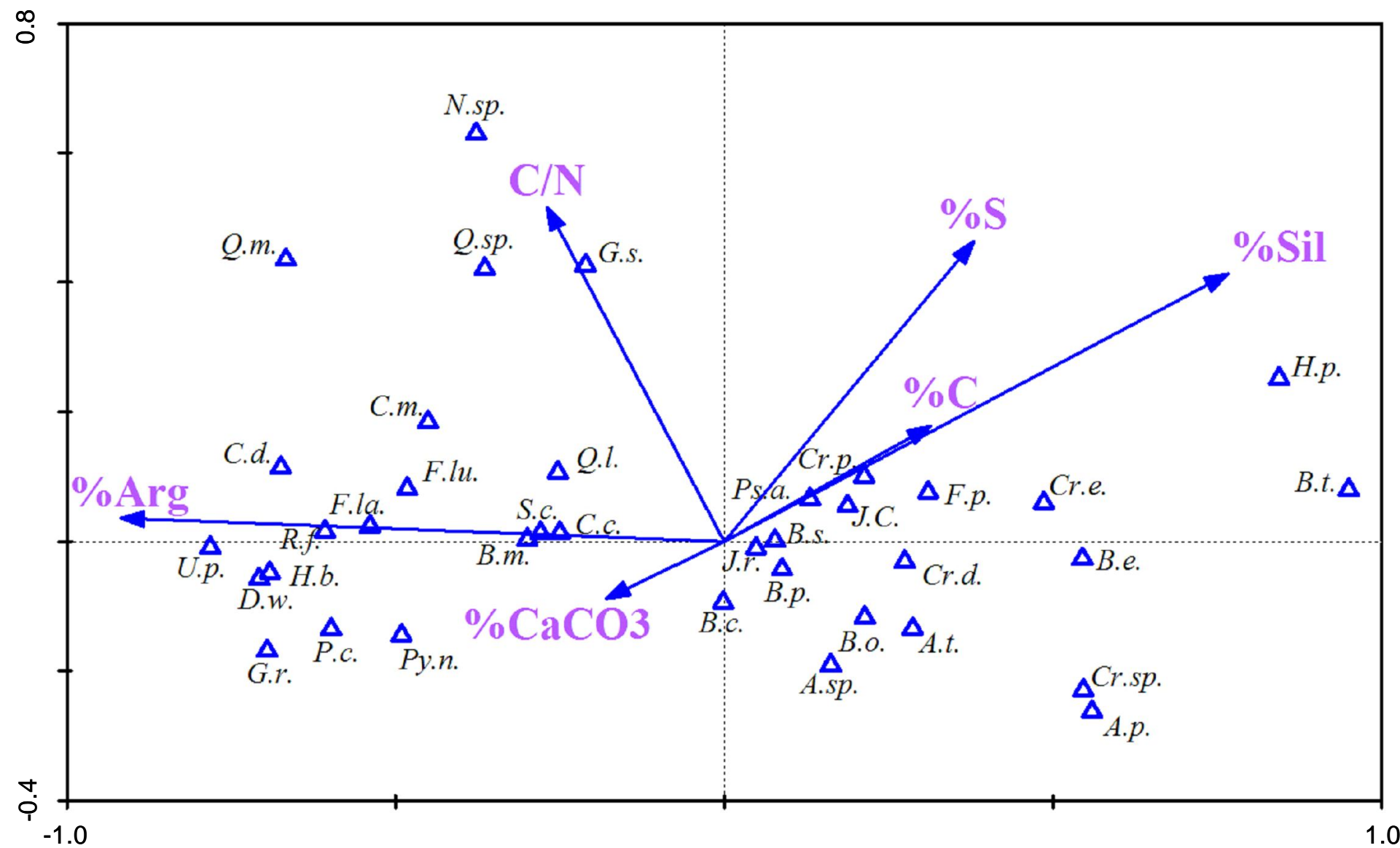

Figura 23: Biplot de espécies e variáveis ambientais para os testemunhos UB1 e UB3.A.p. $=$ Ammonia parkinsoniana . A.t. $=$ Ammonia tepida . A. sp. $=$ Ammonia sp. B.c. $=$ Bolivina compacta . B.e. $=$ Buliminella elegantissima . B.o. $=$ Bolivina ordinaria . B.p. $=$ Bolivina pulchella . B.t. $=$ Bolivina translucens. C.c. $=$ Cassidulina crassa f. media . C.d. $=$ Cibicides dispars. C. $\mathbf{m} .=$ Cassidulina minuta . Cr. $\mathbf{d} .=$ Cribroelphidium discoidale . Cr. . $=$ Cribroelphidium excavatum

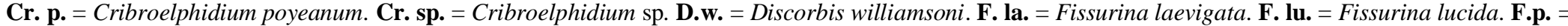
Fursenkoina pontoni. G. $\mathbf{r} .=$ Globigerinoides ruber. G. $\mathbf{s} .=$ Globocassidulina subglobosa . H.b. $=$ Hanzawaia boueana . H. $\mathbf{p} .=$ Hopkinsina pacifica. J. C. $=$ Jovem Cribroelphidium. J. r. = Jovem rotalineo. N. sp. $=$ Neocornubina sp. P.c. $=$ Pararotalia cananeiaensis. Py. $\mathbf{\text { n. }}=$ Pyrgo nasuta $. \mathbf{Q} . \mathbf{l}$. $=$ Quinqueloculina

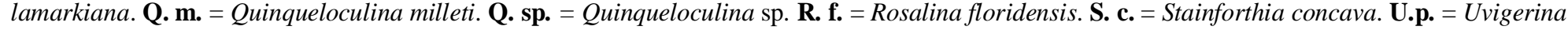
peregrina. $\mathrm{C} / \mathrm{N}=$ razão carbono-nitrogênio. $\% \mathrm{~S}=$ porcentagem de enxofre. $\% \mathrm{C}=$ porcentagem de carbono. $\% \mathrm{CaCO}_{3}=$ porcentagem carbonato de cálcio. $\%$ Arg $=$ porcentagem de argila. \% Sil = porcentagem de silte 


\section{CAPÍTULO 6: Discussão}

\section{Comparacão das Associacões de Foraminíferos Recentes e Sub-recentes das}

\section{Enseadas do Flamengo e da Fortaleza}

Os valores de densidade e de riqueza de espécies das associações de foraminíferos recentes das enseadas do Flamengo (Lançone et al., 2005; Fonseca, 2005) e da Fortaleza (Filippos, 2006) são ligeiramente diferentes daqueles encontrados nos sedimentos do topo dos testemunhos UB1 e UB3.

Fonseca (2005) encontrou valores de densidade e de riqueza relativamente altos na entrada do Saco da Ribeira (4.888 foraminíferos/10cc e 34 espécies). Já na porção mais interna e confinada desse local, a autora encontrou apenas um exemplar de foraminífero. Em termos de biocenose, Fonseca (2005) encontrou raros exemplares corados. Essa diferença encontrada pela autora, em pontos de coleta tão próximos, está relacionado ao fato de que na entrada do Saco da Ribeira (i.e, na região onde ocorre o estrangulamento das pontas do Lagosteiro e do Flamengo) há um canal, que permite a circulação moderada das águas de fundo. Nesta região há maior concentração dos teores de oxigênio dissolvido nos sedimentos, resultando em maior abundância de foraminíferos. Por outro lado, na porção mais confinada do Saco da Ribeira, a situação que prevalece é completamente redutora, devido à quase ausência de circulação de fundo (Fonseca, 2005).

Os valores de densidade e riqueza encontrados no topo do testemunho UB1 são baixos (155 foraminíferos/10cc e 18 espécies) quando comparados aos encontrados por Fonseca (2005) na entrada do Saco da Ribeira. Ao se analisar todos os valores de densidade e riqueza ao longo da coluna sedimentar, constata-se uma diminuição progressiva, da base ao topo do testemunho, sugerindo confinamento progressivo desta região nos últimos 7.500 anos A.P.

Lançone et al. (2005), apesar de não terem estudado a região Saco da Ribeira e, sim, outros sub-ambientes da Enseada do Flamengo, encontraram riquezas e densidades semelhantes àquelas apresentadas na porção superior do testemunho UB1.

Já na Enseada da Fortaleza, Filippos (2006) encontrou valores de densidade e riqueza ligeiramente inferiores aos encontrados nos sedimentos de topo do testemunho 
UB3 (26176 foraminíferos/10cc e 41 espécies), o que demonstra que a Praia do Lázaro, onde foi coletado o testemunho UB3, possui condições mais favoráveis aos foraminíferos que as regiões dos pontos de coleta utilizados pela autora supracitada.

Filippos (2006) encontrou valores de densidade e riqueza maiores que os encontrados por Fonseca (2005) no Saco da Ribeira. Este mesmo padrão foi demonstrado ao longo dos testemunhos UB1 e UB3. Isto ocorre porque, desde aproximadamente 7.500 anos A.P., a Praia do Lázaro é uma área com circulação mais intensa que a apresentada pelo Saco da Ribeira.

As associações de foraminíferos encontradas na Enseada do Flamengo (Lançone et al., 2005; Fonseca, 2005) e da Fortaleza (Filippos, 2006) são constituídas pelos mesmos gêneros encontrados no topo dos testemunhos UB1 e UB3, com predominância de espécies de testas hialinas e raros textulariíneos.

De acordo com Fonseca (2005), atualmente no Saco da Ribeira, não há presença expressiva de espécies indicadoras de Água Central do Atlântico Sul (ACAS) e Água Tropical (AT). Contudo, nas regiões mais profundas da Praia do Lázaro, as porcentagens das espécies indicadoras de ACAS são comparativamente maiores que as porcentagens encontradas no Saco da Ribeira (Filippos, 2006). Espécies indicadoras de ambiente rico em oxigênio são pouco abundantes, tendo maior representação na Enseada da Fortaleza do que na Enseada do Flamengo. A maior porcentagem das espécies recentes identificadas corresponde a representantes da massa de água Água Costeira (AC) e de matéria orgânica, tal como ocorre nos dois testemunhos. Os gêneros Ammonia e Cribroelphidium são predominantes nas amostras recentes da Enseada do Flamengo, e os gêneros Pararotalia, Ammonia, Cribroelphidium e Bulimina predominam nas amostras recentes da Enseada da Fortaleza. Nos primeiros centímetros dos testemunhos, os gêneros predominantes foram Ammonia e Buliminella em UB1 e Ammonia, Cribroelphidium, Cassidulina e Bolivina em UB3.

A composição e estrutura das associações de foraminíferos encontradas ao longo dos testemunhos UB1 e UB3 também não se modificaram completamente no decorrer do Holoceno, apresentando-se semelhantes às associações recentes descritas para a Enseada do Flamengo (Duleba et al., 1999; Lançone et al., 2005; Duleba et al., 2005; Fonseca, 2005) e para a Enseada da Fortaleza (Filippos, 2006). Isso significa que o ambiente deposicional estudado sempre foi o de plataforma interna, e que as mudanças 
ambientais que ocorreram ao longo do Holoceno nessas enseadas se processaram de forma gradual, de maneira que as associações de foraminíferos tiveram sempre tempo de se adaptar às novas condições ambientais e, portanto, não tiveram sua estrutura drasticamente modificada.

Exceção a essa evolução ambiental gradual ocorreu entre 102 e $100 \mathrm{~cm}$ de profundidade no testemunho UB3 (Enseada da Fortaleza). Nesse intervalo sedimentar, há variação brusca e considerável dos valores de densidade e riqueza da associação de foraminíferos, tendo sido encontradas apenas sete testas. Como não foram encontradas, na literatura, modificações bruscas nos parâmetros ambientais das enseadas durante esse período, e os dados abióticos para este intervalo sedimentar do testemunho UB3 não foram obtidos, esse fenômeno de quase ausência de foraminíferos no intervalo de 102$100 \mathrm{~cm}$ de profundidade permanece inexplicável, até que estudos mais aprofundados dos fatores abióticos da Praia do Lázaro sejam efetuados.

Os dados morfométricos obtidos para associações recentes de foraminíferos nas enseadas do Flamengo (Duleba et al., 1999; Lançone et al., 2005; Duleba et al., 2005; Fonseca, 2005) e da Fortaleza (Filippos, 2006) indicam o mesmo padrão observado ao longo dos testemunhos UB1 e UB3, ou seja, predomínio de testas de tamanho médio (entre 125 e $250 \mu \mathrm{m})$, seguido por testas de tamanho pequeno $(<125 \mu \mathrm{m})$. Testas grandes (entre 250 e $500 \mu \mathrm{m}$ ) foram encontradas em sedimentos recentes para as duas enseadas em suas porções menos abrigadas, como, por exemplo, nas suas desembocaduras, e em alguns pontos estudados no Saco da Ribeira por Fonseca (2006).

Ainda, testas recentes encontradas nas enseadas do Flamengo (Duleba et al., 1999; Lançone et al., 2005; Duleba et al., 2005; Fonseca, 2005) e da Fortaleza (Filippos, 2006) não têm, em sua maioria, alteração em sua coloração, tal como ocorre ao longo dos testemunhos. Dentre as testas de coloração alterada, são predominantes aquelas preenchidas por sulfeto de ferro (piritizadas) e por matéria orgânica nas porções mais abrigadas das enseadas, como é o caso do Saco da Ribeira e da Praia do Lázaro. Já nas porções menos abrigadas, como, por exemplo, nas desembocaduras, testas limonitizadas (acastanhadas) são mais abundantes.

Contudo, apesar das associações de foraminíferos dos testemunhos UB1 e UB3 serem as mesmas que ocorrem atualmente, variações de suas composições faunísticas (entre suas densidades e a dominância de certas espécies em determinados intervalos de 
profundidade) ao longo dos dois testemunhos permitiram detectar importantes variações ambientais holocênicas, conforme será exposto a seguir.

\section{Composicões Faunísticas ao Longo dos Testemunhos UB1 e UB3}

As associações de foraminíferos das bases dos testemunhos UB1 e UB3 possuem menores densidades e riquezas, e são compostas por espécies indicadoras das massas de água AC, AT e ACAS, sendo que a indicação da presença das massas de água AT e ACAS é mais forte no testemunho UB1. Espécies indicadoras de M.O., de ambiente deficiente em oxigênio e da infauna se mostram mais abundantes, mas espécies indicadoras de ambiente oxigenado e pertencentes à epifauna também estão presentes, ainda que em menor quantidade. Espécies de testas porcelanosas também são encontradas, ainda que em baixas porcentagens. Essas características indicam que à essa época o ambiente marinho era mais oxigenado e possuía circulação de fundo menos restrita que a que ocorre atualmente.

A partir de $192-190 \mathrm{~cm}$ em UB1 e de $282-280 \mathrm{~cm}$ em UB3, os valores de densidade das associações de foraminíferos de ambos os testemunhos aumentam consideravelmente. Espécies indicadoras de M.O. ocorrem em alta quantidade, assim como espécies indicadoras de AC, AT e ACAS. Foraminíferos disaeróbicos e infaunais também ocorrem abundantemente, enquanto formas epifaunais e óxicas diminuem sua quantidade e aqueles de testas porcelanosas tendem a diminuir. Essas modificações sugerem aumento da lâmina de água nas enseadas do Flamengo e da Fortaleza, bem como decréscimo dos teores de oxigênio disponível no meio bentônico.

A partir dessas profundidades de 192-190 cm em UB1 e de 282-280 cm em UB3, os valores de riqueza e densidade do Saco da Ribeira diminuem em direção ao topo do testemunho, enquanto na Praia do Lázaro os valores de densidade e riqueza tendem a aumentar.

De 190 a $92 \mathrm{~cm}$ em UB1 e de 280 a $142 \mathrm{~cm}$ em UB3, as espécies porcelanosas não são abundantes. Nesses intervalos, espécies indicadoras de M.O., de ambiente óxico, da epifauna e indicadoras da AT e da ACAS diminuem, enquanto espécies indicadoras da AC aumentam. Entre 142 e $140 \mathrm{~cm}$, devido à presença da camada de matéria orgânica depositada no testemunho UB1, ocorrem aumentos consideráveis de espécies disaeróbicas, infaunais, indicadoras de M.O. e de ACAS. 
Já na Praia do Lázaro, há incremento de espécies epifaunais e óxicas, ainda que a maior porcentagem continue sendo de espécies infaunais e disaeróbicas. Espécies porcelanosas ocorrem em porcentagens mais baixas, espécies indicadoras de M.O. decrescem e espécies indicadoras de AC, AT e ACAS sofrem ligeiro aumento.

Essa disparidade entre as associações de foraminíferos a partir de $190 \mathrm{~cm} \mathrm{em}$ UB1 e $280 \mathrm{~cm}$ em UB3 sugere que, dessa época em diante, as enseadas do Flamengo e da Fortaleza começaram a apresentar características ambientais diferenciadas. Na primeira enseada, o ambiente tornou-se cada vez mais deficiente em oxigênio, com circulação mais restrita, enquanto para a segunda, o ambiente permaneceu com circulação de fundo mais eficiente, ou seja, mais oxigenado.

De 90 a 32 cm em UB1, as espécies óxicas diminuem, assim como as espécies infaunais, ao passo que as espécies epifaunais aumentam sua quantidade. Espécies indicadoras de M.O. ocorrem com maior abundância entre 62 e $60 \mathrm{~cm}$ e, em seguida, tendem a diminuir. Espécies indicadoras de AT e ACAS diminuem consideravelmente, com exceção do intervalo de 42-40 cm, onde as que indicam presença da AT aumentam ligeiramente. Ao contrário, espécies indicadoras de AC apresentam valores crescentes até $72-70 \mathrm{~cm}$, quando passam a diminuir levemente.

Já no testemunho UB3, entre 140 e $32 \mathrm{~cm}$, espécies indicadoras de ambiente oxigenado aumentam suas porcentagens, apesar de não serem tão representativas quanto as espécies disaeróbicas. O mesmo se dá com as espécies epifaunais e infaunais. Espécies indicadoras de M.O. também aumentam, assim como aquelas que são indicadoras de AC (predominantes). As espécies indicadoras de AT e ACAS diminuem até 102-100 cm e, então, aumentam sua quantidade rumo ao topo do testemunho.

Essas modificações sugerem que, no Saco da Ribeira, o ambiente se tornava cada vez mais restrito e menos oxigenado, enquanto na Praia do Lázaro, esse foi um período de pequeno aumento de oxigenação do meio e de leve aumento da circulação de fundo.

Entre 32 e $30 \mathrm{~cm}$ nos dois testemunhos há aumento dos valores de riqueza e diminuição dos valores de densidade das associações de foraminíferos. Além disso, espécies indicadoras de M.O. tendem a diminuir em ambas as enseadas. Essas mudanças se devem à modificação dos ambientes deposicionais de UB1 e UB3. 
De 30 a 12 cm em UB1, espécies disaeróbicas e epifaunais aumentam e espécies infaunais diminuem, tornando-se menos expressivas que as epifaunais entre 20 e $12 \mathrm{~cm}$ de profundidade. Espécies indicadoras de AC, AT e ACAS aumentam. A presença de foraminíferos porcelanosos só ultrapassa $1 \%$ entre 12 e $10 \mathrm{~cm}$ de profundidade. Já no testemunho UB3, entre 30 e $12 \mathrm{~cm}$, a presença de foraminíferos porcelanosos é pouco maior (entre 3\% e 5\%). Espécies infaunais e disaeróbicas predominam sobre aquelas epifaunais e óxicas, mas tendem a diminuir. Espécies indicadoras de $\mathrm{AC}$ aumentam, e espécies indicadoras de AT e ACAS diminuem.

Dessa forma, pode-se supor que entre 30 e $12 \mathrm{~cm}$ de profundidade, no Saco da Ribeira, a circulação de fundo se tornou pouco menos restrita e a depleção de oxigênio foi pouco menor, enquanto para essa mesma profundidade, na Praia do Lázaro, o ambiente se tornou pouco menos disaeróbico, com circulação de fundo pouco mais restrita.

Entre 12 e $0 \mathrm{~cm}$ de profundidade em UB1, espécies indicadoras de AT e de ACAS são quase inexistentes. Também diminuem as espécies indicadoras de M.O. Foraminíferos óxicos são encontrados no topo do testemunho, mas ocorrem em porcentagens inferiores que a de espécies disaeróbicas, e foraminíferos epifaunais diminuem bastante sua quantidade, mas ainda são mais abundantes que as formas infaunais. Já no testemunho UB3, entre 12 e $0 \mathrm{~cm}$, há presença de espécies indicadoras de AC, AT e ACAS. Espécies indicadoras de M.O. também estão presentes, mas diminuem ligeiramente nesses primeiros doze centímetros de UB3. Foraminíferos infaunais e disaeróbicos predominam, mas há presença conspícua de espécies epifaunais e óxicas.

Essas evidências microfaunísticas sugerem que, para o tempo de deposição dos primeiros $12 \mathrm{~cm}$ de UB1, o Saco da Ribeira foi ambiente com circulação de fundo bastante restrita, e com depleção de oxigênio cada vez mais acentuada rumo ao topo do testemunho. Nesse mesmo período, na Praia do Lázaro, a circulação de fundo continuou menos restrita, e o ambiente demonstrou menor depleção de oxigênio que aquela apresentada pelo Saco da Ribeira. 


\section{Análise Morfométrica ao Longo dos Testemunhos UB1 e UB3}

Ao longo dos dois testemunhos, o predomínio é o de testas de tamanho médio (125-250 $\mu \mathrm{m})$. Segundo Bernhard (1986), o tamanho das testas dos foraminíferos é diretamente proporcional à quantidade de oxigênio disponível no ambiente. Dessa forma, ambientes com baixos teores deste elemento só provêm quantidades suficientes dele para atividade metabólica de foraminíferos que possuem testas de tamanhos mais reduzidos (Bernhard \& Alve, 1996; Filippos, 2006). Assim sendo, o predomínio de testas de tamanho médio ao longo dos testemunhos indica que tanto o Saco da Ribeira quanto a Praia do Lázaro não foram ambientes completamente desprovidos de oxigênio, apesar de apresentarem baixas concentrações deste elemento e terem, portanto, características redutoras.

Além disso, a maior concentração de foraminíferos de tamanho médio também indica que essas regiões possuíram, desde aproximadamente 7.500 anos A.P., energia hidrodinâmica moderada, já que as correntes marinhas atuantes na área não possuíam força suficiente para retrabalhar essas testas e aquelas de tamanhos maiores.

Apesar desse predomínio dos tamanhos médios, o comportamento de testas pequenas $(<125 \mu \mathrm{m})$ e grandes $(250-500 \mu \mathrm{m})$ indicam algumas modificações ambientais pelas quais passaram as enseadas.

No testemunho UB1, testas grandes predominam sobre as pequenas entre 192$190 \mathrm{~cm}$, quando a quantidade de foraminíferos aumentou consideravelmente no Saco da Ribeira, correspondendo esse período à época em que o nível do mar ultrapassou o atual pela primeira vez durante a Transgressão Santos; entre 162-160 cm e entre 122 e $40 \mathrm{~cm}$, tempo em que o nível marinho ascendia até o Máximo Transgressivo, que ocorreu por volta de 5.100 anos A.P. (Suguio et al., 2005), e começava a regredir. Durante esses períodos supracitados, a circulação no Saco da Ribeira devia ser maior, já que o Tômbolo do Saco da Ribeira ainda não existia e, portanto, havia conexão hídrica entre as enseadas. Essa maior circulação de fundo pode ter sido responsável pelo aumento da porcentagem das testas grandes.

Ainda de acordo com Fonseca (2005), a presença de foraminíferos de tamanhos grandes no Saco da Ribeira pode estar correlacionada à presença do canal submarino nele existente, que proporcionaria maior circulação de fundo. 
Entre 82 e $70 \mathrm{~cm}$, testas grandes são mais abundantes não apenas que as pequenas, mas também que as médias. Nessa mesma profundidade, a presença da massa de água AC era grande, e as massas de água AT e ACAS influenciaram muito pouco o Saco da Ribeira. Além disso, as porcentagens de $\mathrm{CaCO}_{3}$ aumentaram bastante. Essa estabilidade ambiental aliada à disponibilidade de carbonato de cálcio no ambiente deposicional permitiram a construção de testas de foraminíferos calcários que atingissem tamanhos maiores.

Já os tamanhos pequenos nesse testemunho predominam sobre os grandes nos demais intervalos amostrados. O tamanho reduzido das testas de foraminíferos dentro da associação pode ser proveniente de condições adversas do ambiente ou se constituir de reflexo de reprodução precoce devido a condições ambientais ótimas (Boltvoskoy \& Wright, 1976). Segundo Bradshaw (1961, apud Duleba, 1993), quantidades maiores de nutrientes disponíveis no meio permitem que os foraminíferos amadureçam sexualmente no início de seus estágios ontogenéticos, o que lhes permite se reproduzirem mesmo antes de alcançarem tamanhos maiores.

Assim sendo, as testas de tamanho pequeno no Saco da Ribeira podem ser devidas tanto à depleção de oxigênio, cada vez maior nesse ambiente, quanto podem ser reflexo da quantidade de matéria orgânica nele disponível. Elas ocorrem em maiores porcentagens principalmente entre 142-140 cm, quando o acúmulo dessa matéria orgânica depositada no Saco da Ribeira foi bastante alto; e entre 32 e $0 \mathrm{~cm}$ de profundidade, quando o Saco da Ribeira possuía condições ambientais melhores, mais oxigenadas, como mostram as espécies bioindicadoras encontradas nesse intervalo.

No testemunho UB3, testas grandes são quantitativamente mais expressivas que testas pequenas apenas entre $320-300 \mathrm{~cm}$, quando se depositaram areias sílticas na Praia do Lázaro; entre 52 e $40 \mathrm{~cm}$, quando se depositaram siltes arenosos, e entre 12 e $10 \mathrm{~cm}$, quando sedimentos mais grossos, de areia síltica, gradam a siltes arenosos. Nesses intervalos de profundidade, os sedimentos mais grossos devem ter permitido maior circulação de oxigênio em seus interstícios. A menor depleção de oxigênio e a disponibilidade de $\mathrm{CaCO}_{3}$ devem ter permitido a construção de testas calcárias maiores.

Testas pequenas predominam sobre as grandes nos demais intervalos sedimentares e, entre 162-160 cm e 82-80 cm, são mais expressivas não apenas que os tamanhos grandes, mas também que os médios. Como no caso do Saco da Ribeira, 
também na Praia do Lázaro testas de tamanhos reduzidos podem ser devidas à depleção de oxigênio do meio ou, também, à presença conspícua de matéria orgânica nessa região que, aliada a outros fatores ambientais, pode ter permitido a reprodução precoce das espécies, antes que alcançassem tamanhos maiores.

A presença de testas pequenas e grandes, além de médias, na Praia do Lázaro e no Saco da Ribeira, atestam que esses ambientes, apesar de possuírem circulação mais restrita, não são ou foram completamente desprovidos dela. Ou seja, que foram, desde aproximadamente 7.500 anos A.P., ambientes de circulação moderada. As maiores porcentagens de testas pequenas em detrimento das grandes na maior parte de ambos os testemunhos coaduna com o padrão de circulação moderada para as enseadas.

\section{$\underline{\text { Análise Tafonômica ao Longo dos Testemunhos UB1 e UB3 }}$}

A maior porcentagem das testas de foraminíferos analisadas ao longo dos testemunhos UB1 e UB3 apresentou coloração normal, ou seja, esbranquiçada. Entretanto, há presença de testas preenchidas por sulfeto de ferro (douradas), monossulfeto de ferro (que vão de prateadas a negro-iridescentes) ou por matéria orgânica (com pontos negros disseminados por sua superfície).

Entre essas testas de coloração alterada, predominam aquelas preenchidas por sulfeto de ferro. Essa predominância indica que o ambiente tanto no Saco da Ribeira quanto na Praia do Lázaro, apesar de possuir circulação moderada, teve desde cedo tendências redutoras, visto que a precipitação do sulfeto de ferro se dá por meio da reação do ácido sulfídrico $\left(\mathrm{H}_{2} \mathrm{~S}\right)$ com o ferro $(\mathrm{Fe})$ em ambientes empobrecidos em oxigênio (Berner, 1970; Leão \& Machado, 1989; Murray, 1991). O ferro presente nas enseadas deve ter sido trazido pelos cursos de água existentes nas enseadas, sendo proveniente de rochas-fonte continentais (Eichler, 1982; Duleba, 1993). Já o enxofre necessário à formação da pirita (sulfeto de ferro) é proveniente da ação de bactérias sulfato-redutoras. A presença dessas bactérias foi detectada por Duleba (1993) e por Cândia-Hollangel \& Duleba (1993), na Enseada do Flamengo.

A presença de testas contendo matéria orgânica, apesar destas possuírem porcentagens baixas, indica que o Saco da Ribeira e a Praia do Lázaro foram desde 
aproximadamente 7.500 anos A.P. ambientes de circulação mais restrita, que permitiu a concentração dessa matéria orgânica na interface sedimento-água.

Já testas contendo matéria orgânica são mais raras, mas ocorrem em maior quantidade entre 222 e $210 \mathrm{~cm}$, onde foram observadas areias sílticas; em torno de 142$140 \mathrm{~cm}$, quando há a deposição da camada de matéria orgânica nesse testemunho e entre 62-60 cm, quando há acúmulo de material biodetrítico em UB1.

No testemunho UB3, testas douradas tendem a aumentar em direção ao topo do testemunho, até $42-40 \mathrm{~cm}$, a partir de onde diminuem. Testas preenchidas por monossulfeto de ferro ocorrem em maiores porcentagens entre 262 e $150 \mathrm{~cm}$, época em que o nível do mar ultrapassou o nível atual pela primeira vez durante a Transgressão Santos e ascendeu até o Máximo Transgressivo, entre 72 e $50 \mathrm{~cm}$ e no topo de UB3, quando se depositaram sedimentos mais grossos, de areia síltica e silte arenoso, na Praia do Lázaro. Já testas contendo matéria orgânica são mais expressivas entre 272 e 172 cm, época de ascensão do nível do mar, e entre $62 \mathrm{~cm}$ e o topo do testemunho, quando se depositaram sedimentos mais grossos e o ambiente era menos redutor.

Os processos post mortem encontrados nas testas de foraminíferos analisadas ao longo dos testemunhos UB1 e UB3 indicam que as energias hidrodinâmicas dessas regiões, apesar de moderadas, não foram fortes o suficiente para alterarem a composição original das associações microfaunísticas encontradas, já que testas inteiras ocorrem em concentrações muito mais elevadas que testas alteradas. A variação das porcentagens de testas inteiras, parcial ou totalmente fragmentadas indica que houve mudanças no padrão da circulação hídrica no Saco da Ribeira e na Praia do Lázaro ao longo dos últimos 7.500 anos A.P.

No testemunho UB1, as testas inteiras diminuem rumo ao topo do testemunho. Entretanto, entre 142-140 cm, há aumento de sua porcentagem, provavelmente devido à deposição da camada de matéria orgânica no Saco da Ribeira. Elas predominam sobre testas total ou parcialmente fragmentadas entre 192 e $130 \mathrm{~cm}$ e entre 62 e $40 \mathrm{~cm}$ de profundidade.

Nesses períodos supracitados, o nível marinho se encontrava em ascensão e em regressão, respectivamente, correspondendo a intervalos amostrais em que o ambiente deposicional era formado por sedimentos mais finos (siltes arenosos e siltes) e se mostrava pouco oxigenado (redutor). 
No testemunho UB3, testas inteiras predominam sobre testas parcial e totalmente fragmentadas entre 142 e $40 \mathrm{~cm}$ de profundidade, período em que o nível do mar estava ascendendo, alcançou o Máximo Transgressivo e começou a regredir, correspondendo a ambientes cujos sedimentos são constituídos por siltes e siltes arenosos.

Já testas parcial e totalmente fragmentadas predominam nos demais intervalos de ambos os testemunhos, quando as condições ambientais não eram tão estáveis. Dentre essas testas, a maioria está corroída ou bioerodida, o que significa que, apesar da baixa circulação hídrica das enseadas, as ações bacteriana e de organismos marinhos predadores foram responsáveis por grande parte da alteração post mortem das testas.

Dessa forma, pode-se supor que o grande predomínio de testas brancas sobre as preenchidas e de testas inteiras sobre as total ou parcialmente fragmentadas indica que o ambiente deposicional de ambas as enseadas não era completamente redutor, e possuía circulação de fundo moderada.

\section{Correlacão Entre Dados Bióticos e Abióticos}

\section{Índice Ammonia - Elphidium e modelo TROX}

Os valores de hipoxia encontrados por meio do índice Ammonia-Elphidium (Sen Gupta et al., 1996) ao longo dos testemunhos indicam que a presença de matéria orgânica e a depleção de oxigênio no Saco da Ribeira e na Praia do Lázaro, tornaram-se maiores nos últimos centímetros tanto de UB1 quanto de UB3, apresentando-se mais evidentes no primeiro testemunho em relação ao segundo.

Esses valores indicam que os ambientes deposicionais do Saco da Ribeira e da Praia do Lázaro tornaram-se progressivamente mais deficientes em oxigênio, principalmente nos períodos mais recentes. No Saco da Ribeira, essa depleção de oxigênio, causada pela restrição cada vez maior de sua circulação, se iniciou em torno de 62-60 $\mathrm{cm}$ de profundidade, época em que o nível do mar estaria se rebaixando e o Tômbolo do Saco da Ribeira teria passado a impedir a circulação entre as enseadas. Já para a Praia do Lázaro o gráfico apresenta valores mais baixos até $22-20 \mathrm{~cm}$ de profundidade, a partir de onde começam a crescer. 
Os altos valores dos gráficos do índice de hipoxia do meio tanto para UB1 quanto para UB3 em suas amostras de topo são devidos à quase ausência da espécie Cribroelphidium excavatum nessas amostras. Essa espécie, apesar de oportunista, suporta baixos teores de oxigênio por tempo bem menor que espécies do gênero Ammonia (Sen Gupta et al., 1996). Dessa forma, pode-se supor que a ausência de Cribroelphium excavatum nas amostras de topo dos testemunhos indica que os ambientes deposicionais do Saco da Ribeira e da Praia do Lázaro, atualmente, apresentam fortes tendências redutoras.

Entretanto, os valores da razão $\mathrm{C} / \mathrm{S}$ indicam ambiente oxidante para os últimos $12 \mathrm{~cm}$ do testemunho UB1. Esses altos valores da razão $\mathrm{C} / \mathrm{S}$ são devidos à baixa quantidade de enxofre (S) no ambiente deposicional nas duas últimas amostras do testemunho UB1. Essa baixa concentração de $\mathrm{S}$ nas amostras superficiais do testemunho ocorreram, provavelmente, por problemas amostrais no momento da coleta de UB1, quando os sedimentos de topo desse testemunho devem ter sido lavados (Duleba, com. pessoal). Esse fato explicaria a razão de, apesar da baixa porcentagem de espécies indicadoras de ambiente rico em oxigênio no topo do testemunho, a razão $\mathrm{C} / \mathrm{S}$ estar alta.

Em sedimentos recentes da Enseada do Flamengo, Fonseca (2005) achou valores de salinidade e temperatura condizentes com a massa de água AC. Também as amostras de topo do testemunho UB1 indicam porcentagens altas de espécies indicadoras de $\mathrm{AC}(65,65 \%)$ e quase ausência de espécies indicadoras de AT $(0,76 \%)$ e ACAS (0,76\%). Ainda, as espécies de Ammonia parkinsoniana encontradas em ambos os testemunhos sugerem que os ambientes deposicionais foram ambientes em que não ocorreram grandes variações na estratificação da salinidade, já que, segundo Todd \& Brönnimann (1957) e Petri \& Vieira (1975), espécies de Ammonia parkinsoniana que sem ornamentações indicam que as modificações de salinidade no meio foram pequenas. Esse fato comprova a maior influência da massa de água AC na área de estudo e, assim, coaduna os resultados de circulação moderada na área de estudo, posto que outras massas de água estariam presentes caso a energia hidrodinâmica fosse maior. A circulação mais restrita na área atesta o quadro de depleção de oxigênio demonstrado pelos gráficos do Índice Ammonia-Elphidium. 
O aumento gradual para o índice Ammonia-Elphidium no testemunho UB1 indica que as condições de hipoxia para o Saco da Ribeira são mais antigas e maiores que aquelas apresentadas pela Praia do Lázaro. Isso porque, quanto maior o valor do índice, maior é a indicação de depleção de oxigênio no meio. Dessa forma, entre 52-50 cm em UB1, a hipoxia do meio já era de 6,38\%, apresentando-se crescente a partir de então. Já para o testemunho UB3, o índice de hipoxia apresenta valores crescentes a partir de $52-50 \mathrm{~cm}$ com porcentagem de $5,26 \%$ e só a partir de $22-20 \mathrm{~cm}$ essa porcentagem se amplia.

O fato de a lâmina de água estar se tornando menor e a circulação entre as enseadas ser inexistente nesse período não é, entretanto, o único fator responsável por essa forte hipoxia do meio. Martin et al. (1984 apud Duleba et al, 1999) estudaram os sedimentos da Foz do Rio Doce e determinaram inversão de transporte de seus sedimentos entre 3.900 e 3.600 anos A. P. De acordo com Duleba et al. (1999) as modificações da circulação atmosférica que teriam causado essa modificação de transporte sedimentar também teriam ocasionado modificações hidrodinâmicas costeiras e afetado a Enseada do Flamengo, provocando maior depleção de oxigênio nessa enseada durante essa época.

O Modelo TROX (TR - trófico, nutrientes; OX - oxigênio) de Jorissen et al. (1995) coaduna com a hipótese de ambiente com baixo teor de oxigênio e acúmulo considerável de matéria orgânica tanto para o Saco da Ribeira quanto para a Praia do Lázaro. De acordo com esse modelo, a primeira determinação da profundidade do substrato em que os microrganismos vivem é realizada pela observação da disponibilidade de oxigênio. Em seguida, havendo disponibilidade desse elemento, observa-se a disponibilidade de nutrientes.

No Saco da Ribeira, a baixa concentração de oxigênio é o principal fator, então, determinante da profundidade de nichos ocupados pelos foraminíferos bentônicos infaunais. A maior parte dessas espécies encontradas nos testemunhos UB1 e UB3 tem modo de vida livre e hábito alimentar detritívoro. Segundo Corliss \& Chen $(1988$, apud Duleba et al., 1999), essas espécies penetram o substrato marinho até nichos ecológicos profundos, onde se alimentam de detritos. Segundo o modelo TROX, essa possibilidade só existe em ambientes mesotróficos, onde a distribuição de foraminíferos é controlada pela disponibilidade de nutrientes. Dessa forma, tanto o Saco da Ribeira quanto a Praia 
do Lázaro são ambientes que possuem concentração alta a moderada de nutrientes e baixas concentrações de oxigênio. As condições ambientais da Praia do Lázaro são, entretanto, pouco menos restritas que aquelas encontradas no Saco da Ribeira, ou seja, há maior quantidade de oxigênio disponível nos interstícios de seus sedimentos e, portanto, o principal fator responsável pela profundidade máxima habitada pelos foraminíferos infaunais de suas associações é a disponibilidade de nutrientes.

\section{Análises de Correlação Canônica (ACC) dos Testemunhos UB1 e UB3}

As porcentagens de variância acumuladas pelos quatro primeiros eixos para os dados das espécies e amostras de UB1 e UB3 foram de 0.965, 0.811, 0.686 e 0.718. Para as relações entre espécies ou amostras e ambientes, as porcentagens de variâncias acumuladas pelos quatro eixos para UB1 e UB3 foram de 78,2\%, 85,2\%, 91,9\% e 96\%. Esses últimos valores indicam que as variáveis ambientais utilizadas para a ACC são suficientes para explicar, aparentemente, a maior parte da variação de abundância das espécies relacionadas ao ambiente deposicional, embora não o possam explicar em sua totalidade. Segundo ter Braak (1988), valores baixos de relação espécie-ambiente são comuns, mas seu significado não se torna menor devido a esse fator. Ainda, o teste de Monte Carlo utilizado para as correlações, com 999 permutações, reforça os resultados encontrados, posto que esse teste correlacionou as variáveis ambientais e as espécies ou as amostras a $5 \%$ de significância.

Quando analisadas conjuntamente, as espécies dos testemunhos UB1 e UB3 se correlacionam significativamente principalmente com as concentrações de silte e argila na fração lamosa dos sedimentos que formam os testemunhos. Secundariamente, através do mesmo eixo (o primeiro), essas espécies recebem influência das concentrações de carbonato de cálcio $\left(\% \mathrm{CaCO}_{3}\right)$ e de carbono orgânico (\% C).

As espécies Hopkinsina pacifica, Bolivina translucens, Buliminella elegantissima, Cribroelphidium sp., Ammonia parkinsoniana, Cribroelphidium excavatum, Fursenkoina pontoni, Cribroelphidium discoidale, Ammonia tepida, Bolivina ordinaria e jovem Cribroelphidium estão relacionados a ambiente deposicional com maiores porcentagens de silte e carbono orgânico, e com baixas porcentagens de carbonato de cálcio e argila. Já Cibicides dispars, Uvigerina peregrina, Globigerinoides 
ruber, Discorbis williamsoni, Pararotalia cananeiaensis, Hanzawaia boueana, Rosalina floridensis, Fissurina laevigata, Pyrgo nasuta, Fissurina lucida, Cassidulina minuta, Brizalina marginata, Stainforthia concava e Cassidulina crassa se relacionam principalmente a ambientes com altas porcentagens de carbonato de cálcio e argila e porcentagens menores de silte e carbono orgânico.

Poucas são as espécies relacionadas aos teores de enxofre e à razão $\mathrm{C} / \mathrm{N}$ (origem da matéria orgânica). Neocornubina sp., Quinqueloculina sp., Globocassidulina subglobosa e Quinqueloculina lamarkiana se relacionam primariamente a ambientes com teores mais elevados de enxofre e com matéria orgânica de origem variando de continental a mista. Já Bolivina compacta e Ammonia sp. se relacionam a ambientes com matéria orgânica de origem mista a marinha e menores teores de enxofre.

As demais espécies estão concentradas na porção mediana do biplot, o que indica que elas se correlacionam a ambientes com matéria orgânica de origem mista e concentrações medianas de carbonato de cálcio, carbono orgânico, enxofre, silte e argila.

As amostras demonstram que o testemunho UB1 se correlaciona a ambiente com maiores porcentagens de silte, de carbono orgânico e de enxofre e com baixas concentrações de carbonato de cálcio e argila, bem como de matéria orgânica de origem marinha. Já o testemunho UB3 possui a maior parte de suas amostras relacionadas a ambientes com maiores concentrações de argila e carbonato de cálcio, baixas porcentagens de silte, carbono orgânico e enxofre e com matéria orgânica de origem continental a mista. Entretanto, as amostras da base desse testemunho (48, 49 e 50, que correspondem à profundidade compreendida entre 342 e $320 \mathrm{~cm}$ ) se correlacionam a ambientes com maiores porcentagens de silte, carbono orgânico e enxofre, ou seja, a ambientes deposicionais semelhantes aos observados para o testemunho UB1. E as amostras 46, 47 e 25 (profundidades compreendidas entre 312 e $300 \mathrm{~cm}$ e $02-0 \mathrm{~cm}$ ) se relacionam a ambientes com porcentagens mais medianas para esses elementos supracitados.

Esses resultados corroboram com aqueles demonstrados pelos estudos microfaunísticos, em que o Saco da Ribeira foi, desde aproximadamente 7.500 anos A.P., ambiente com menor circulação e, portanto, com maior possibilidade de acumulação de carbono orgânico. A menor circulação e a existência de bactérias 
sulfato-redutoras geraram maior concentração de enxofre no meio, bem como baixos teores de oxigênio, a qual é menor no topo e à base do testemunho, como demonstrado pelas espécies de foraminíferos e pelo posicionamento das amostras 1 e 2 (12-0 cm de UB1) e 20, 21, 22 e 23 (222 a 190 cm em UB1), respectivamente, no biplot de amostras de UB1 e UB3.

Enquanto isso, para a Praia do Lázaro, a maior circulação de fundo permitiu a maior concentração de carbonato de cálcio (obtido através de carapaças de organismos marinhos), bem como a maior dispersão de carbono orgânico e de enxofre. A maior bacia de drenagem da Enseada da Fortaleza possibilitou a origem de características mais continentais ou mistas para a matéria orgânica lá encontrada, em detrimento de origem mais marinha.

$\mathrm{O}$ fato de as amostras de base de UB3 terem se depositado em ambiente semelhante ao demonstrado pelas amostras basais de UB1 corrobora a hipótese de ligação entre as enseadas até a, aproximadamente, 5.100 anos A.P. A concentração das amostras de UB1 em um único setor do biplot, bem como o maior espalhamento das amostras de UB3 nesse mesmo biplot, indicam que enquanto o ambiente da Praia do Lázaro sofreu ligeira modificação com o passar do tempo, deixando de ter características mais redutoras e passando a apresentar maior circulação de fundo, o Saco da Ribeira permaneceu ambiente redutor.

Ainda, o fato de as amostras de topo dos testemunhos apontarem características ambientais discrepantes mostra que o Tômbolo do Saco da Ribeira, ao impedir a circulação hídrica entre as enseadas, tornou o Saco da Ribeira e a Praia do Lázaro ambientes deposicionais cada vez mais diferentes.

A análise de correspondência canônica demonstrou, pois, que as associações de foraminíferos do Saco da Ribeira e da Praia do Lázaro estão relacionadas principalmente com o fator de granulometria da fração lamosa do sedimento e, secundariamente, com as porcentagens de carbonato de cálcio, enxofre e carbono orgânico, bem como com a origem da matéria orgânica. Quando considerados separadamente, os principais fatores abióticos que influenciaram as associações de foraminíferos da Praia do Lázaro são as características da matéria orgânica e da porcentagem de silte e argila da fração lamosa do sedimento, enquanto que para as associações de foraminíferos do Saco da Ribeira, os principais fatores ambientais são a 
quantidade de oxigênio disponível no meio e as porcentagens de silte e argila da fração lamosa.

Esses resultados corroboram os dados obtidos nas análises microfaunística e abiótica, bem como os resultados de outros trabalhos realizados anteriormente na área (Duleba, 1993; Duleba et al., 1999; Duleba et al., 2005; Lançone et al., 2005; Fonseca, 2005; Filippos, 2006).

\section{Evolucão Paleoambiental e Suas Evidências Microfaunísticas}

De acordo com as evidências apresentadas pelos resultados microfaunísticos e abióticos obtidos para os testemunhos UB1 e UB3, foi possível reconhecer duas fases marinhas distintas nas Enseadas do Flamengo e da Fortaleza. Essas duas fases compreendem uma primeira, transgressiva, que teria ocorrido até, aproximadamente, 5.100 anos A. P., e outra entre 5.100 anos A. P até o presente, de caráter regressivo.

As bases dos testemunhos UB1 (222-192 cm) e UB3 (342-282 cm), datadas em aproximadamente 7.500 anos A. P., caracterizam-se por possuírem sedimentos mais grossos (areias e areias sílticas), valores baixos de densidade, de riqueza e de $\mathrm{CaCO}_{3}$, valores decrescentes das razões $\mathrm{C} / \mathrm{N}$ e $\mathrm{C} / \mathrm{S}$ e pela presença de espécies indicadoras de M.O. e das massas de água AC, AT e ACAS, bem como de espécies óxicas, epifaunais e porcelanosas.

Esses resultados sugerem que possivelmente em torno de 7.500 anos A. P., a coluna de água das porções mais internas das enseadas da Fortaleza e do Flamengo era menor que a atual, ou seja, que essa região era ambiente marinho mais raso, provavelmente caracterizado como região entre-marés.

Essa interpretação está de acordo com os trabalhos de Duleba (1993), Duleba et al. (1999) e Mahiques et al. (1999), que encontraram tubos de Callichirus major e areias estéreis e/ou com conteúdo microfaunístico quase inexistente na sucessão sedimentar basal de testemunhos coletados na Enseada do Flamengo. Essas evidências foram interpretadas pelos autores supracitados como indícios de paleolinha de costa nessa enseada por volta de 7.500 anos A. P. Também coaduna com os resultados de Sonvesso (2007), que demonstrou que as características da matéria orgânica da Enseada da Fortaleza por volta de 8.600 anos A. P. apresentavam menor tendência marinha, bem 
como com os demais trabalhos sobre variação do nível do mar realizados na costa sudeste brasileira (Ybert et al., 2003; Suguio et al., 2005; Angulo et al., 2006).

A partir de 192-190 cm em UB1 e 282-280 cm em UB3, constatou-se mudança do substrato marinho nas enseadas com deposição de termos mais finos (siltes e siltes arenosos). Esses dois intervalos amostrais se caracterizam por apresentarem aumento considerável dos valores de densidade, aumento dos teores de $\mathrm{CaCO}_{3}$ e valores baixos para as razões $\mathrm{C} / \mathrm{N}$ e $\mathrm{C} / \mathrm{S}$, e também por possuírem espécies indicadoras de M.O. e das massas de água AC, AT e ACAS, além de espécies disaeróbicas e infaunais, em abundância.

Essas características sugerem que a essa época havia aumento da lâmina de água nas enseadas do Flamengo e da Fortaleza, causada pela ascensão marinha que ocorria nessa região. A circulação de fundo era livre entre as enseadas, como sugere a semelhança entre as microfaunas pertencentes ao Saco da Ribeira e à Praia do Lázaro. Essas microfaunas também indicam que esses ambientes se tornavam progressivamente mais deficientes em oxigênio. $\mathrm{O}$ aumento da lâmina de água causou, possivelmente, mudanças nos ambientes deposicionais do Saco da Ribeira e da Praia do Lázaro que os tornaram mais propícios à proliferação das associações dos foraminíferos.

De acordo com as datações radiométricas realizadas em ambos os testemunhos, essas profundidades de 192-190 cm em UB1 e de 282-280 cm em UB3 provavelmente equivalem à época em que o nível do mar ultrapassou o nível marinho atual pela primeira vez no Holoceno, segundo Suguio et al. (2005).

Além do trabalho supracitado, essas interpretações estão de acordo com outros trabalhos sobre variação do nível do mar realizados no litoral sudeste brasileiro (Suguio \& Tessler, 1984; Suguio et al., 1985; Angulo et al., 2006).

As sucessões sedimentares seguintes de UB1 (190-92 cm) e de UB3 (280-142 $\mathrm{cm}$ ) se caracterizam por apresentarem sedimentos pelíticos (silte arenoso, silte e silte argiloso) e aumento dos teores de $\mathrm{CaCO}_{3}$. Em UB1, esses sedimentos possuem aumento dos valores da razão $\mathrm{C} / \mathrm{N}$, diminuição do valores de $\mathrm{C} / \mathrm{S}$, de riqueza e de densidade rumo ao topo do testemunho. Possuem, em abundância, espécies indicadoras de AC, infaunais e disaeróbicas e, em menor quantidade, espécies indicadoras de M.O. e das massas de água AT e ACAS. Já em UB3, os sedimentos pelíticos apresentam valores decrescentes para as razões $\mathrm{C} / \mathrm{N}$ e $\mathrm{C} / \mathrm{S}$ e valores crescentes de riqueza e densidade rumo 
ao topo do testemunho. Espécies infaunais e disaeróbicas e espécies indicadoras de AC, AT, ACAS e de M.O. ocorrem abundantemente.

Essas evidências sugerem o afogamento progressivo do Saco da Ribeira e da Praia do Lázaro até há, aproximadamente, 5.100 anos A. P., bem como sugerem que esses ambientes, principalmente o Saco da Ribeira, se tornavam mais redutores.

Segundo Moulinier (1981), não se pode explicar a ocorrência ou ausência de todas as espécies de foraminíferos de determinada região apenas por meio de um único fator ecológico, visto que os fatores limitantes para cada uma delas é diferente. Dessa forma, a escassez de oxigênio cada vez maior no Saco da Ribeira refletiu nos valores cada vez menores de densidade e riqueza de suas associações de foraminíferos, bem como no incremento de espécies infaunais e disaeróbicas.

Como na Praia do Lázaro a circulação de fundo nessa época de ascensão marinha era menos restrita que aquela demonstrada pelo Saco da Ribeira, bem como era menor a depleção de oxigênio disponível na região, os valores de riqueza e densidade aumentaram em UB3 a medida em que o ambiente se afogava, tornando-se mais estável.

Nessa época, segundo Suguio et al. (2005), ocorreu o Máximo Transgressivo da Transgressão Santos, por volta de 5.100 anos A. P. O aumento da lâmina de água durante esse intervalo temporal de transgressão marinha até o Máximo Transgressivo tornou o Saco da Ribeira e a Praia do Lázaro ambientes progressivamente mais estáveis. A circulação entre esses dois ambientes a essa época deveria ocorrer sem impedimentos, pois o pontão do embasamento que mais tarde formaria o Tômbolo do Saco da Ribeira deveria estar submerso, permitindo que as massas de água que chegavam à Enseada da Fortaleza vindas de sudoeste passassem à Enseada do Flamengo. As massas de água AT e ACAS, por serem mais densas e, portanto, circularem mais próximas ao assoalho, encontravam sua passagem parcialmente impedida pelo pontão do embasamento, o que explica o fato de a circulação do Saco da Ribeira ser menor que a da Praia do Lázaro. Devido a essa menor circulação, havia maior acúmulo de M.O. no Saco da Ribeira, o que justifica a maior concentração de espécies indicadoras de M.O. nesse ambiente em relação à Praia do Lázaro.

Essas interpretações coadunam com as curvas de variação do nível do mar elaboradas para o litoral sudeste brasileiro (Suguio \& Tessler, 1984; Suguio et al., 1985; Angulo \& Suguio, 1995; Angulo \& Lessa, 1997; Martin et al., 1998; Ybert et al., 2003; 
Suguio et al., 2005; Angulo et al., 2005; Angulo et al., 2006), bem como com o trabalho de Duleba et al. (1999), que estudou evidências microfaunísticas de testemunhos coletados na Enseada do Flamengo para análise da evolução da circulação hídrica nessa enseada.

De 90 a 32 cm em UB1 depositaram-se sedimentos mais grossos, sílticoarenosos, que apresentam granocrescência ascendente. Há altos teores de $\mathrm{CaCO}_{3}$, aumento dos valores da razão $\mathrm{C} / \mathrm{S}$ e diminuição dos valores da razão $\mathrm{C} / \mathrm{N}$. Nesses sedimentos ocorrem abundantemente espécies da AC, indicadoras de M.O., infaunais e disaeróbicas. Espécies da AT e da ACAS, óxicas e epifaunias ocorrem em menor quantidade.

Nessa mesma época, entre 140 e $32 \mathrm{~cm}$ em UB3, depositaram-se sedimentos pelíticos (silte, silte argiloso e silte arenoso) com granocrescência ascendente e presença de vegetais oxidados dispersos. Os teores de $\mathrm{CaCO}_{3}$ aumentam ligeiramente, os valores da razão $\mathrm{C} / \mathrm{S}$ são baixos e os valores da razão $\mathrm{C} / \mathrm{N}$ são pouco maiores. Nesses sedimentos são encontradas em abundância espécies indicadoras de M.O., da AC, da ACAS e da AT, bem como espécies infaunais e disaeróbicas. Espécies óxicas e epifaunais aumentam sua quantidade, apesar de não serem tão representativas.

Esses resultados permitem supor que a partir de, aproximadamente, $92 \mathrm{~cm}$ em UB1 e $142 \mathrm{~cm}$ em UB3, o regime marinho se inverteu, mudando de transgressivo a regressivo, na região das enseadas do Flamengo e da Fortaleza. Indicam ainda que, a partir do momento em que o nível do mar começou a regredir na região de Ubatuba, a região do Saco da Ribeira se tornou cada vez mais restrita e deficiente em oxigênio, ao passo que a região da Praia do Lázaro continuou apresentando circulação de fundo menos restrita, com maior quantidade de oxigênio. Essa acentuada modificação ambiental, que ocasionou diferenciação entre as associações de foraminíferos das duas enseadas, deveu-se, provavelmente, ao surgimento do Tômbolo do Saco da Ribeira. Isso porque, quando o nível do mar passou a regredir e o volume da lâmina de água não era mais suficiente para suplantar a altitude do tômbolo, este passou a impedir a circulação hídrica entre as enseadas. Dessa forma, a Praia do Lázaro continuou recebendo influência marinha das correntes vindas de sudoeste, ao passo que o Saco da Ribeira deixou de receber essa influência. As correntes marinhas que banham a Enseada do 
Flamengo passaram a entrar nessa enseada apenas por sua desembocadura, de forma que a região do Saco da Ribeira ficou mais restrita à atuação delas.

Em torno de 32-30 cm de profundidade em UB1 e em UB3, ocorreu mudança ambiental que causou alteração no padrão de sedimentação, com deposição rápida e brusca de sedimentos mais grossos no Saco da Ribeira e na Praia do Lázaro. Como não foram encontradas evidências de contato discordante por Sonvesso (2007) em seus estudos sedimentológicos, descarta-se a hipótese de lacuna sedimentar e, portanto, de perda de informação para esse período. Dessa forma, supõe-se que esses sedimentos mais grossos, constituídos de areias, que gradam a areias sílticas, depositadas em UB1 e de areias sílticas depositadas em UB3, são provenientes de regiões continentais próximas, e se depositaram durante evento de modificação dos padrões ambientais que existiam nas enseadas nesse período temporal.

Essa modificação ambiental se deve, provavelmente, ao aumento da pluviosidade local (Duleba, com. pessoal). O aumento de chuvas em determinadas épocas do ano nessa região de Ubatuba ocasiona escorregamentos nas encostas da Serra do Mar nas regiões circunvizinhas ao Saco da Ribeira (Duleba, com. verbal) e, muito provavelmente, também à Praia do Lázaro. Considera-se, portanto, que como esses fenômenos ocorrem nos dias atuais, também deveriam ocorrer à época da deposição das areias e areias sílticas nos testemunhos UB1 e UB3. Esses escorregamentos carreariam sedimentos mais grossos, continentais, até a sua deposição no Saco da Ribeira e na Praia do Lázaro.

Assim sendo, essas areias seriam provenientes de áreas continentais próximas. Essa hipótese explicaria a menor seleção das areias da Praia do Lázaro nesse intervalo deposicional em detrimento dos demais intervalos de UB3, bem como a presença mais freqüente de grânulos em UB1. Esse menor grau de seleção é característico de depósitos formados por escorregamento de encostas.

Sonvesso (2007) considera a hipótese de que essas areias mais grossas e menos selecionadas sejam provenientes de transporte torrencial durante período de chuvas mais intensas associadas à mudança na hidrodinâmica da região. Mas essa autora descarta a hipótese de que esses fatos sejam suficientes para explicar todas as características desses depósitos arenosos. Ela assume, dessa forma, que a hipótese mais adequada para 
explicar essas areias e areias sílticas seja a de rebaixamento do nível do mar nessa época para essa região (Sonvesso, 2007).

Eichler (1982) estudou os sedimentos recentes da Enseada do Flamengo e concluiu que, devido aos baixos graus de arredondamento, a área-fonte dos sedimentos estava próxima à enseada, pois indicam transporte curto de partículas. Esses resultados fortalecem a hipótese acima apresentada, de areias provenientes de escorregamento de áreas emersas próximas. Já Mahiques (1992) havia interpretado que sucessões sedimentares mais grossas, depositadas no testemunho FLT4 (localizado próximo ao testemunho UB1), seriam provenientes de escorregamentos continentais. Tais sucessões são correlacionáveis àquelas presentes nos testemunho UB1 e UB3, em termos de profundidade.

Entretanto, para que essa teoria seja confirmada, seria necessário realizar um estudo mais aprofundado de fácies e de estruturas dos depósitos sedimentares arenosos do Saco da Ribeira e da Praia do Lázaro.

Essa sucessão sedimentar mais grossa, composta por areias e areias sílticas, se depositou de 32 a $10 \mathrm{~cm}$ de profundidade nos dois testemunhos e apresenta granodecrescência ascendente. Nesses sedimentos, os teores de $\mathrm{CaCO}_{3}$ diminuem e os valores da razão $\mathrm{C} / \mathrm{S}$ aumentam. Há aumento dos valores de riqueza e decréscimo dos valores de densidade. No testemunho UB1, as espécies indicadoras de AC, AT e ACAS aumentam, assim como as espécies disaeróbicas e epifaunais. Já no testemunho UB3, as espécies infaunais e disaeróbicas e as indicadoras de AT e ACAS diminuem, enquanto espécies indicadoras de AC aumentam.

Essas evidências demonstram que o ambiente se tornava menos redutor, chegando a ser oxidante entre 12 e $10 \mathrm{~cm}$ de profundidade em UB1 e entre 22 e $20 \mathrm{~cm}$ em UB3. No Saco da Ribeira, a circulação se tornou pouco menos restrita, enquanto na Praia do Lázaro a circulação de fundo se tornou pouco menos forte, ainda que continuasse sendo menos restrita que no Saco da Ribeira. Essas características podem significar que, a essa época, o nível do mar estava mais baixo nas enseadas do Flamengo e da Fortaleza.

A curva das mudanças do nível do mar para os últimos 7.000 anos A. P. apresentada por Suguio et al. (2005) indica que houve queda do nível marinho abaixo do nível atual em torno de 2.800 anos A. P., e já em 2.500 anos A. P. o nível marinho 
estaria novamente entre 1,5 a 2 m acima do nível atual, entrando em rebaixamento contínuo até os dias atuais. Para a realização deste trabalho, Suguio et al. (2005) utilizaram escala temporal da ordem de milênios, apresentando, portanto, a tendência geral do rebaixamento marinho.

Utilizando-se de escala temporal diferente, da ordem de décadas, Mesquita (1994) concluiu através de dados de maregramas que nos últimos 40 anos o nível marinho na região de Cananéia, litoral norte do estado de São Paulo, estaria em ascensão, aumentando $30 \mathrm{~cm} /$ século. Já segundo trabalhos realizados na costa sul brasileira, no Rio Grande do Sul (Tomazelli, 1990; Tomazelli et al., 1998), o nível marinho teria estado em ascensão desde cerca de 2.000 anos A. P. até o presente.

Essa diferença encontrada entre os estudos supracitados se deve não somente à diferença entre as escalas temporais neles utilizadas como, também, aos diferentes processos tectônicos e/ou às diferentes variações regionais do nível do mar que ocorreram nas regiões por eles estudadas.

Entre 12 e $0 \mathrm{~cm}$ de profundidade os testemunhos UB1 e UB3 se caracterizam por apresentarem sedimentos mais finos (silte arenoso) com granodecrescência ascendente. No testemunho UB1, os valores da razão C/S são altos e os da razão C/N são pouco menores. Os teores de $\mathrm{CaCO}_{3}$ decrescem, bem como diminuem drasticamente as espécies indicadoras da AT e da ACAS. Também diminuem as espécies epifaunais, apesar de ainda serem mais abundantes que as infaunais. Espécies disaeróbicas e indicadoras da AC são abundantes. Foraminíferos indicadores de M.O. são numerosos, mas diminuem rumo ao topo de UB1, e espécies óxicas não são encontradas. No testemunho UB3, os valores das razões $\mathrm{C} / \mathrm{S}$ e $\mathrm{C} / \mathrm{N}$ diminuem ligeiramente. Os teores de $\mathrm{CaCO}_{3}$ aumentam, bem como aumentam as espécies indicadoras de AC, AT, ACAS e de M.O. Há predomínio de espécies infaunais e disaeróbicas.

Essas evidências sugerem que a circulação hídrica na Praia do Lázaro foi menos restrita, embora o ambiente fosse redutor, com matéria orgânica de origem continental. Já no Saco da Ribeira, nessa mesma época, a circulação teria diminuído drasticamente, embora o ambiente se mostrasse pouco menos redutor. A matéria orgânica dessa região teria, nesse mesmo período, origem mista. 
Apesar do gráfico referente ao microhabitat indicar maior quantidade de espécies da epifauna nas amostras de topo do testemunho UB1, deve-se considerar que essas amostras de topo são compostas principalmente por Ammonia spp. e Buliminella elegantissima, com maior porcentagem da primeira em relação à segunda. A Ammonia, apesar de ter sido considerada espécie epifaunal para a construção dos gráficos referentes de epifauna e infauna versus profundidade, pode também ser encontrada habitando o interior do sedimento, ou seja, pode também apresentar hábito de vida infaunal.

Ainda, segundo Corliss \& Emerson (1990), quando houver menor concentração de carbono orgânico no sedimento, a matéria orgânica lábil (aquela utilizada na nutrição dos foraminíferos) tende a se concentrar preferencialmente nas camadas superficiais do sedimento. Nesse caso, surgem as espécies epifaunais e, portanto, a ligeira queda nas porcentagens de espécies indicadoras de matéria orgânica nas amostras de topo do testemunho UB1 coaduna com a hipótese de menor concentração de matéria orgânica lábil em sedimentos do Saco da Ribeira nesse período.

$\mathrm{Na}$ Praia do Lázaro, a origem predominantemente continental da matéria orgânica, em detrimento da origem mista encontrada no Saco da Ribeira, deve refletir maior rede de drenagem local apresentada pela Enseada da Fortaleza, a Bacia do Rio Escuro, que é uma das mais volumosas da região de Ubatuba.

Todas essas evidências indicam que o nível do mar nos primeiros $12 \mathrm{~cm}$ dos testemunhos UB1 e UB3 exibem características de lâmina de água mais espessa que aquela que existia durante a sedimentação dos $20 \mathrm{~cm}$ sotopostos.

Apesar dessas modificações, sugeridas pelas associações de foraminíferos entre 32 e $0 \mathrm{~cm}$ de profundidade nos dois testemunhos, essas alterações não parecem ter sido tão drásticas a ponto de indicarem rebaixamento do nível oceânico abaixo do nível médio atual. Elas também não sugerem mudanças significativas de salinidade, por eventual aporte mais volumoso de águas continentais para a região. Não houve também variações drásticas de valores de riqueza ou densidade de foraminíferos, bem como não aconteceram modificações notáveis nos valores de freqüências relativas das espécies. Dessa forma, supõe-se que tenha ocorrido queda do nível oceânico a partir do Máximo Transgressivo até, pelo menos, 32-30 cm de profundidade de UB1 e UB3, quando se depositaram sedimentos mais grossos nas enseadas. A partir dessa profundidade, as 
associações de foraminíferos demonstram tendência geral para aumento da lâmina de água.

Essas interpretações estão de acordo com Sonvesso (2007), que encontrou granodecrescência ascendente nos sedimentos de topo dos testemunhos. Essa autora também admitiu este resultado como evidência de ascensão da lâmina de água na época nas enseadas do Flamengo e da Fortaleza.

Entretanto, outros trabalhos, como os de Angulo et al. (1999, 2005), questionam as evidências de oscilações secundárias do nível marinho a partir do Máximo Transgressivo. Por outro lado, o estudo microfaunístico de apenas dois testemunhos deste tipo, também, não é suficiente para elucidar essa questão regional, e são necessários estudos mais aprofundados para que se possa comprovar até que ponto o nível médio do mar abaixou durante os últimos 5.100 anos A. P. nas enseadas do Flamengo e da Fortaleza em Ubatuba. 


\section{CAPÍtULO 7: Conclusões}

As associações de foraminíferos do Saco da Ribeira (Enseada do Flamengo) e da Praia do Lázaro (Enseada da Fortaleza), ao longo dos últimos 7.500 anos A.P., são constituídas por espécies típicas de plataforma interna. Contudo, a partir da variação dos parâmetros de densidade, riqueza e variação das porcentagens entre as espécies, foi possível detectar importantes mudanças paleoambientais, que provavelmente estariam relacionadas ao afogamento progressivo das duas enseadas pelo aumento do nível relativo do mar neste intervalo de tempo.

A presença de testas de tamanhos médio e pequeno, ao longo dos dois testemunhos, também atesta que o Saco da Ribeira e a Praia do Lázaro foram, desde 7.500 anos A. P. até o presente, ambientes com energia de fundo moderada. As espécies bioindicadoras encontradas sugerem o predomínio de Água Costeira nas enseadas, e alto conteúdo de matéria orgânica nos sedimentos. Durante este mesmo período, a hidrodinâmica da Praia do Lázaro foi menos restrita que a do Saco da Ribeira, com

aporte de Água Central do Atlântico Sul e de Água Tropical, enquanto no Saco da Ribeira a ocorrência dessas duas massas de água foi bastante inferior, indicando circulação hídrica mais restrita.

As maiores porcentagens de espécies infaunais, detritívoras, disaeróbicas, de testas pouco ornamentadas e densamente perfuradas por poros, indicam que o Saco da Ribeira e a Praia do Lázaro foram e continuam como ambientes mesotróficos de circulação restrita. No Saco da Ribeira, as condições ambientais tornaram-se cada vez mais eutrofizadas e propiciaram o decréscimo dos valores de densidade e riqueza dos foraminíferos da base rumo ao topo do testemunho UB1 ao passo que, no testemunho UB3, esses valores cresceram, visto que a circulação não se restringiu ainda mais com o passar do tempo e o ambiente não sofreu grande eutrofização.

A análise tafonômica das testas encontradas indicou que não houve transporte de testas suficientemente violento para modificar as associações de foraminíferos, no decorrer do tempo geológico na região estudada. As porcentagens de testas inteiras e fragmentadas mostram que a energia do ambiente era moderada no Saco da Ribeira e na Praia do Lázaro, embora a energia envolvida fosse pouco mais elevada no segundo ambiente deposicional. 
A existência de testas preenchidas por sulfeto de ferro e monossulfeto de ferro indica ambiente redutor, mas não completamente anóxico, já que testas brancas são predominantes em ambos os testemunhos.

De acordo com os dados bióticos obtidos e com as datações realizadas nos testemunhos UB1 e UB3, foi possível verificar que as associações de foraminíferos apresentaram similaridade entre as enseadas do Flamengo e da Fortaleza da base dos testemunhos, há aproximadamente 7.500 anos A.P., até as profundidades de 142-140 cm (5.040 \pm 40 anos A.P.) em UB1 e 202-200 cm (5.320 \pm 40 anos A.P.) em UB3, época equivalente ao máximo transgressivo da Transgressão Santos, que ocorreu por volta de 5.100 anos A.P. (Suguio et al., 2005). A partir dessas profundidades, quando o nível do mar começou a regredir, as associações de foraminíferos passaram a apresentar padrões bioindicadores distintos.

As associações encontradas para o Saco da Ribeira demonstraram que essa região passou a apresentar características de confinamento cada vez maiores. O hidrodinamismo arrefeceu, assim como diminuíram os teores de oxigênio e aumentaram os conteúdos de matéria orgânica, causando grau de hipoxia cada vez mais elevado na região. Já na Praia do Lázaro, a circulação não se restringiu e as modificações apresentadas pelo meio foram mais suaves que aquelas demonstradas pelo Saco da Ribeira.

Essas modificações que passaram a ocorrer entre as enseadas são provavelmente devidas à formação da feição hoje conhecida como Tômbolo do Saco da Ribeira, que até 5.100 anos A.P. parecia não existir, mas que, com o rebaixamento do nível marinho, passou a atuar como barreira entre as enseadas do Flamengo e da Fortaleza, que impediu a circulação entre elas. Como não havia mais comunicação entre a Praia do Lázaro e o Saco da Ribeira, as características tornaram-se distintas em relação às suas microfaunas de foraminíferos bentônicos.

Além da formação do Tômbolo do Saco da Ribeira, outras ocorrências na região determinaram mudanças dos parâmetros ambientais que refletiram positiva ou negativamente nas associações de foraminíferos bentônicos. Uma dessas ocorrências pode estar relacionada à mudança nos sentidos de propagação das frentes de onda, que atingem as enseadas, como aconteceu em torno de 3.900 anos A.P., causada por mudanças paleoclimáticas sugeridas por Martin et al. (1984, apud Duleba et al., 1999) 
na foz do Rio Doce (ES). Segundo Duleba et al. (1999), este evento pode ter atingido as enseadas da região de Ubatuba causando depleção mais acentuada de oxigênio na Enseada do Flamengo neste período. Esse evento pode corresponder às mudanças sedimentológicas verificadas nos testemunhos UB1 e UB3 por Sonvesso (2007), quando passam a ocorrer areias e areias sílticas com menores graus de seleção e que são provenientes, provavelmente, de escorregamento de sedimentos da área continental adjacente.

De acordo com os dados apresentados, é possível delinear uma linha histórica evolutiva para as enseadas do Flamengo e da Fortaleza, onde o nível oceânico era inferior ao atual entre, aproximadamente, 7.500 anos A.P. até mais ou menos 6.500 anos A.P., quando teria ultrapassado o nível oceânico atual e continuado em ascensão até por volta de 5.100 anos A.P., quando ocorreu o Máximo Transgressivo.

Nesta época, as enseadas do Flamengo e da Fortaleza eram conectadas hidrologicamente, e as correntes litorâneas atuantes passavam da Enseada da Fortaleza para a do Flamengo. Pouco tempo depois, o nível oceânico começou a regredir, e se formou o Tômbolo do Saco da Ribeira, que passou a impedir a comunicação entre as enseadas, não abruptamente, mas gradualmente, à medida que o nível do mar se rebaixava.

Por volta de 3.900 anos A.P., mudanças paleoclimáticas teriam causado variações nos padrões de frentes de onda da região de Ubatuba e, também, permitido a chegada de frentes frias à região, o que possibilitou, simultaneamente ao rebaixamento do nível oceânico, sedimentação diferenciada devida ao maior grau de hipoxia do meio, e conseqüente modificação nas características ambientais e nas associações de foraminíferos viventes na área.

Este fato parece corroborar a idéia de nível oceânico abaixo do atual há cerca de 3.900 anos A.P., conforme sugerido por Suguio et al. (1985), contrariamente à hipótese proposta mais recente de Angulo \& Lessa (1997).

Pouco depois, o nível oceânico teria recomeçado a ascender, tornando as condições ambientais, pouco a pouco, mais estáveis, até atingir as características ambientais e geológicas atualmente encontradas na região.

Essas interpretações estão de acordo com os trabalhos anteriores realizados nessa área, bem como com os resultados de estudos abióticos de Sonvesso (2007) nos 
testemunhos UB1 e UB3, aqui analisados. Segundo essa autora, tais resultados indicam que o clima na região de Ubatuba foi distinto pelo menos entre 7.500 anos A.P. e 5.000 anos A.P. e entre 5.000 anos A.P. e o presente. A primeira época corresponderia à parte inicial do período conhecido na literatura como "Idade Hipsitérmica (ou Ótimo Climático)", quando o nível oceânico estava em ascensão e o clima era mais quente (Sonvesso, 2007). Com base em dados abióticos (granulométricos e geoquímicos), essa autora propôs que as bases dos testemunhos corresponderiam a um nível do mar mais baixo que o atual nas enseadas, seguido por ascensão até por volta de 5.100 anos A.P., época da Transgressão Santos que, a partir de então, passou a regredir, atingindo nível inferior ao atual por volta de 2.000 a 1.800 anos A.P., com prováveis frentes frias atingindo a região nesse período. A partir de então o nível marinho teria ascendido novamente, e ainda hoje se encontraria em ascensão (Sonvesso, 2007).

Com exceção, pois, da proposição do rebaixamento marinho abaixo do nível médio atual em torno de 2.000 a 1.800 anos A.P. proposto pela autora supracitada, que não pôde ser comprovado ou refutado pelas associações de foraminíferos analisadas em UB1 e UB3, os resultados por ela encontrados corroboram em geral as hipóteses aventadas neste nesse trabalho. A interpretação de Sonvesso (2007) de provável rebaixamento do nível oceânico abaixo do atual com contribuição de frentes frias, que passaram pela região das enseadas, pode corresponder às mudanças paleoclimáticas registradas por Martin et al. (1984, apud Duleba et al., 1999) na foz do Rio Doce (ES), que teriam atingido as enseadas do Flamengo e da Fortaleza, conforme idéias de Duleba et al. (1999).

Com relação aos primeiros $32 \mathrm{~cm}$ de profundidade dos testemunhos, apenas as características das associações de foraminíferos existentes em UB1 e UB3 não são suficientes para esclarecer até que ponto o nível do mar regrediu e quando passou a transgredir. Estudos mais aprofundados (maior detalhamento de amostragem dos $32 \mathrm{~cm}$ de topo dos testemunhos UB1 e UB3, dados de maregramas, novas testemunhagens e novos estudos bióticos, abióticos e isotópicos) fazem-se necessários para que se possa comprovar até que ponto o nível marinho regrediu após o Máximo Transgressivo da Transgressão Santos, quando recomeçou a ascender e se ainda se encontra em ascensão, nos dias atuais, na região de Ubatuba. 


\section{CAPÍTULO 8 - Referências Bibliográficas}

Almeida, F. F. M. 1976. The system of continental rifts bordering the Santos Basin, Brazil. Anais da Academia Brasileira de Geociências, 48:15-26.

Angulo, R. J. \& Suguio, K. 1995. Re-evaluation of the Holocene sea-level máxima for the state of Paraná, Brazil. Palaeogeography, Palaeoclimatology, Palaeoecology. 113: 385-393.

Angulo, R. J. \& Lessa, G. C. 1997. The Brazilian sea-level curves: a critical revew with emphasis on the curves from Paranaguá and Cananéia regions. Marine Geology, 140: $141-166$.

Angulo, R. J. Gianninni, P. C., Suguio, K. e Pessenda, L. C. R. 1999. Relative sea-level changes in the last 5,500 years in Southern Brazil (Laguna-Imbituba region, Santa Catarina State) based on vermetid 14C ages. Marine Geology, 159: 323-339.

Angulo, R. J., de Souza, M. C., Reimer, P. e Sasaoka, S. K. 2005. Reservoir effect of the southern and southeastern Brazilian coast. Radiocarbon, 47: 1-7.

Angulo, R. J.; Lessa, G. C. \& Souza, M. C. de. 2006. A critical review of mid- to lateHolocene sea-level fluctuations on the eastern Brazilian coastline. Quaternary Science Reviews, 25: 486-506.

Aristeu, A.T. 1998. Análise da Circulação superficial oceânica na costa sudeste-sul do Brasil, a partir da utilização dos dados de derivadores rastreados por satélites. Dissertação de Mestrado. Ministério da Ciência e Tecnologia, Instituto Nacional de Pesquisas Espaciais - INPE. São José dos Campos, São Paulo.

Berner, R. A. 1970. Sedimentary Pyrite Formation. American Journal of Science, 268: $1-23$ 
Bernhard, J. M. 1986. Characteristics assemblages and morphologies of benthic Foraminifera from anoxic, organic-rich deposits: Jurassic through Holocene. Journal of Foraminiferal Research, 16:207-215.

Bernhard, J. M. \& Alve, E. 1996. Survival, ATP pool, and ultrastructural characterization of foraminifera from Drammensfjord (Norway): Response to anoxia. Marine Micropaleontology, 28: 5-17.

Boltovskoy, E., 1958. On the organization of foraminiferal collections. Cushman Found. Foram. Res., Contr., 9(4): 99-102.

Boltovskoy, E. 1964. Províncias zoogeográficas de América del Sur su sector antártico segun los foraminíferos bentônicos. Bolm. Inst. Biol. Mar., 7:93-98.

Boltovskoy, E. \& Wright, R. 1976. Recent Foraminífera. Dr. W. Junk, Netherlands, The Hague. 515p.

Boltovskoy, E.; Giussani, G.; Watanabe, S; Wright, R. 1980. Atlas of Benthic Shelf Foraminifera od the Southwest Atlantic. DR. W. Junk bv Publishers, The Hague, Boston-London.

Boltovskoy, E.; Scott, D. B. e Medioli, F. S. 1991. Morphological variations of benthic foraminiferal tests in response to changes in ecological parameters: a review. $J$. Paleontol., 65(2):175-185.

Borrego, J.; Lopez, M.; Pendon, J. G. e Morales, J. A. 1998. C/S Ratios in estuarino sediments of the Odiel River-mouth, S. W. Spain. Journal of Coastal Research, 14(4): 1276-1283.

Candia-hollangel, H. C. \& Duleba, W. 1993. Estudos preliminares da ocorrência do gênero Clostridium em testemunho na Enseada do Flamengo, Ubatuba (lat. 23X30 'S - 45X09 'W), Brasil. Trabalho apresentado no Simpósio sobre Ecossistemas da Costa Brasileira, 3, Serra Negra, 1993. Resumos, Serra Negra, Academia Brasileira de Ciências. 
Castro Filho, B.M.; Miranda, L.B. \& Miyao, S.Y. 1987. Condições hidrográficas na Plataforma Continental ao largo de Ubatuba: variações sazonais em média escala. Bol. Inst. Oceanogr. 35(2):135-151. São paulo.

Corliss, B. H. \& Emerson, S. 1990. Distribution of Rose Bengal stained deep-sea benthic foraminifera from the Nova Scotian continental margin and Gulf of Maine. Deep-Sea Research. 37:381-400.

Debenay, J. P.; Tsakiridis, E.; Soulard, R. e Grossel, H.; 2001. Factors determining the distribuition of foraminiferal assemblages in Port Joinville Harbor (Ille d'Yeu, France): the influence of pollution. Marine Micropaleontology, 43: 75-118.

Dias, G. T. M. 1996. Classificação de sedimentos marinhos: proposta de representação em cartas sedimentológicas. Anais do XXXIX Cong. Bras. Geol. 3:423-426.

Duleba, W. 1993. Variações nas associações de foraminíferos ao longo da coluna sedimentar da Enseada do Flamengo, Ubatuba, SP. Dissertação (Mestrado) Instituto Oceanográfico, Universidade de São Paulo, São Paulo.

Duleba, W. 1997. Variações nas associações de tecamebas, foraminíferos e ostracodes sub-recentes na região de Cananéia-Iguape, S.P. Tese (Doutorado), USP, Inst. Oceanogr., São Paulo, 225p.

Duleba, W.; Debenay, J-P e Eichler, B. B. 1997. Temporal changes in holocene lagoonal assemblages of foraminifera and thecamoebian from Cananéia-Iguape, Brazil. In: International Conference "Application od Micropaleontology in Environmental Sciences", 1, 1997. Tel Aviv. Abstract Book: Tel Aviv University, 1997. p. 53-54.

Duleba, W.; Debenay, J. P. e Eichler, B. B. 1999. Holocene environmental and water circulation changes: foraminifer morphogroups evidence in Flamengo Bay (SP, Brazil) Journal of Coastal Research, 15: 554-571. 
Duleba, W.; Sanches, T. M. \& Mahiques, M. M. 2003. Foraminíferos da plataforma continental interna de Ubatuba: Composição, distribuição espacial e temporal. IX Congresso da Associação Brasileira de Estudos do Quaternário, Recife. Resumos Expandidos, v. 1.

Duleba, W.; Coimbra, J. C.; Petri, S. e Barbosa, C. F. 2005. Foraminíferos, tecamebas e ostracodes recentes utilizados como bioindicadores em estudos ambientais brasileiros. In: Sousa, C.R.G.; Suguio, Kenitiro, Santos, M. \& Oliveira, P.E. (eds). Quaternário do Brasil. ABEQUA. Capítulo 9. Riberão Preto, Editora Holos.

Eberwien, A \& Mackensen, A. 2007. Last Glacial Maximum paleoproductivity and water masses off NW-Africa: evidence from benthic foraminifera and stable isotopes.Marine Micropaleontology, artigo in press.

Eichler, B. B. 1982. Caracterização sedimentológica e algumas considerações sobre a ocorrência de foraminíferos na Enseada do Flamengo (Ubatuba), lat.23º 30' Slong. 45 $06^{\prime}$ W, Estado de São Paulo. Tese de Doutorado. Universidade de São Paulo, Instituto Oceanográfico. 109p.

Eichler, B. B. 1989. Contribuição à caracterização ambiental do litoral norte do Estado de São Paulo, com base no estudo de foraminíferos. Simpósio sobre Oceanografia, 1, Bol. De Res., Instituto Oceanográfico, São Paulo. 109p.

Eichler, E. E. \& Furtado, V.V. 1989. Caracterização Ambiental da Enseada do Flamengo, Ubatuba - São Paulo. Congr. Da Assoc. Bras. De Estudos do Quaternário. Resumos, Rio de Janeiro, p 8.

Faul, K. L.; Ravelo, A. C. e Delaney, M. L. 2000. Reconstructions of upwelling, productivity, and photic zone depth in the eastern equatorial Pacific Ocean using planktonic foraminifera stable isotopes and abundance. Journal of Foraminiferal Research, 30: 110-125. 
Filippos, L. S. 2006. Caracterização ambiental da Enseada da Fortaleza, Ubatuba, SP, baseada em analyses sedimentológicas e em estudos populacionais, morfométricos e tafonômicos de foraminíferos. Monografia (Trabalho de Formatura). Universidade Presbiteriana Mackenzie, São Paulo. 74p.

Folk, R. L. \& Ward, W. C. 1957. Brazos river bar: study of the significance of grain size parameters. Journal of Sedimentary Petrology, 17: 3-27

Fonseca, P. P. 2005. Circulação de fundo da Enseada do Flamengo, Ubatuba, SP, Inferida a Partir da Distribuição Espacial e Morfometria de Foraminíferos. Relatório Final de Inciação Científica, FAPESP, IGc-USP, 35 páginas.

Furtado, V.V. \& Eichler, B.B. 1987. Aspectos ambientais da Enseada do Flamengo, Ubatuba, São Paulo. Mini Simpósio de Biologia Marinha, 6. Resumos, São Sebastião, Centro de Biologia Marinha. p11.

Furtado, V. V. \& Mahiques, M. M. 1990. Distribuição de sedimentos em regiões costeiras e plataforma continental norte do Estado de São Paulo. In: Simpósio de Ecossistemas da Costa Sul e Sudeste Brasileira, Estrutura, Função e Manejo, 2. Academia de Ciências do Estado de São Paulo, 71 (1): 20-29.

Furtado, V.V.; Sanches, T. M. \& Tessler, M. G. 1987. Considerações sobre foraminíferos e suas relações ambientais na região de Ubatuba, S.P. Congr. Bras. de Estudos do Quaternário, 1. Bol. Res., p10. Assoc. Bras. De Estudos do Quaternário, Porto Alegre.

Furtado, V.V.; Tessler, M. G.; Eichler, B. B.; Mahiques, M. M.; Souza, C. R. G \& Sanches, T. M. 1988. Caracterização de ambiente ao longo do litoral paulista - Base para medidas de avaliação do impacto ambiental. Encontro de Docentes $e$ Pesquisadores da USP sobre Meio Ambiente, 1. Bol. Res. p92. Instituto Oceanográfico, USP. 
Gebhardt, H.; Kunt, W. e Holbourn, A. 2004. Foraminiferal response to sea level change, organic flux and oxygen deficiency in the Cenomanian of the Tarfaya Basin, southern Morocco. Marine Micropaleontology, 53 (1-2): 133-157.

Girardeau, J.; Jennings, A. E. e Andrews, J. T. 2004. Timing and mechanisms of surface and intermediate water circulation changes in the Nordic Seas over the last 10,000 cal years: a view from the North Iceland shelf. Quaternary Science Reviews, 23(20-22): 2127-2139

Hallock, P.; Talge, H. K.; Colkey, E. M. e Muller, R. G. 1995. A new disease in reefdwelling foraminifera: implications for coastal sedimentation. Journal of Foraminiferal Research, 25: 280-286.

Hess, S. \& Kuhnt W. 2005. Neogene and Quaternary paleoceanographic changes in the southern South China Sea (Site 1143): the benthic foraminiferal record. Marine Micropaleontology, 54: 63-87.

Jian, Z.; Huang, B.; Kuhnt, W. \& Lin, H-L. 2001. Late Quaternary Upwelling Intensity and East Asian Monsoon Forcing in the South China Sea. Quaternary Research, 55: $363-370$.

Jorissen, F.J.; Stigter, D. C de \& Widmark, J.G.V. 1995. A conceptual model explaining benthic foraminiferal microhabitats. Marine Micropaleontology, 26: 3-15.

Kaiho, K. 1990. Global changes of Paleogene aerobic/anaerobic benthic foraminífera and deep-sea circulation. Palaeography, Palaeoclimatology, Palaeoecology, 83: 6585 .

Kaiho, K. 1994. Benthic foraminiferal dissolved-oxygen index and dissolved-oxygen levels in the modern ocean. Geology, 22: 719-722. 
Kampel, M. \& Gaeta, S. A. 2003. Calculation of primary production from remotelysensed ocean color data: SE Brasil, SW Atlantic. XI SBSR, Anais. Belo Horizonte, INPE. P. 1575-1586.

Lançone, R. B.; Duleba, W. e Mahiques, M. M. 2005. Dinâmica de fundo da Enseada do Flamengo, Ubatuba, Brasil, inferida a partir da distribuição espacial, morfometria e tafonomia de foraminíferos. Revista Brasileira de Paleontologia, 8 (3): 181-192.

Lea, D. W.; Martin, P. A.; Chan, D. A. e Spero, H. J. 1995. Calcium uptake and Calcification rate in the planktonic foraminifer Orbulina universa. Journal of Foraminiferal Research, 25: 14-23.

Leão, Z. M. A. \& Machado, A. J. 1989. Variação da cor dos grãos carbonáticos de sedimentos marinhos atuais. Rev. Bras. Geoc., 19(1):87-91.

Loeblich, A. R \& Tappan, H. 1964. Protista. In: MOORE, R. C. Treatise on invertebrate paleontology, Part C. New York, The University Kansas Press, v1, 510 p., v2, 390p.

Loeblich, A. R. \& Tappan, H. 1988. Foraminiferal genera and their classification. New York: Van Nostrand, v.1, 970p., v.2, 847 pranchas.

Longyin, L.; Gallagher, S. e Finlayson, B. 2000. Foraminiferal response to Holocene environmental changes of a tidal estuary in Victoria, Southeastern Australia. Marine Micropaleontology, 38: 229-246.

Mackensen, A.; Schumacher, S.; Radke, J. e Schmidt, D.N. 2000. Microhabitat preferences and stable carbon isotopes of endobenthic foraminifera: clue to quantitative reconstruction of oceanic new production? Marine Micropaleontology, 40: 233-258.

Magliocca, A. \& Kutner, A. S. 1965. Sedimentos de Fundo da Enseada do Flamengo Ubatuba. Boletim do Instituto Oceanográfico, Física, 8:1-14. 
Mahiques, M. M. 1992. Variações temporais na sedimentação holocênica dos embaiamentos da região de Ubatuba (SP). Tese (Doutorado) - Instituto Oceanográfico, Universidade de São Paulo, São Paulo.

Mahiques, M. M. 1995. Dinâmica sedimentar atual nas enseadas da região de Ubatuba, Estado de São Paulo. Boletim do Instituto Oceanográfico, São Paulo, 43(2):111-122.

Mahiques, M. M.; Mishima, Y e Rodrigues M. 1999. Characteristics of the sedimentary organic matter on the inner and middle continental shelf between Guanabara Bay and São Francisco do Sul, south-eastern Brazilian margin. Continental Shelf Research, 19:775-798.

Mahiques, M. M.; Silveira, I. C. A.; Sousa S. H. M. e Rodrigues, M. 2002. Post-LGM sedimentation on the outer shelf - upper slope of the northernmost part of the São Paulo Bight, southeastern Brazil. Marine Geology, 181(4): 387-400.

Manly, B. F. J. 1991. Randomization, Bootstrap and Monte Carlo Methods in biology. Second ed. Chapman \& Hall, London.

Martin, L.; Bittencourt, A. C. S. P.; Dominguez, J. M. L. 1986. Neotectonic movements on a passive continental margin: Salvador region, Brazil. Neotectonics - An International Journal of Crustal Dynamics, 1: 87-103.

Martin, L.; Bittencourt, A. C. S. P.; Dominguez, J. M. L.; Flexor, J. M. e Suguio, K. 1998. Oscillations or not oscillations, that is the question: Comment on Angulo, R. J. And Lessa, G. C. "The Brazilian sea-level curves: a critical review with emphasis on the curves from the Paranaguá and Cananéia regions" [ Mar. Geol. 140, 141166]. Marine Geology, 150: 179-187.

Matsuura, Y. 1986. Contribuição ao estudo da estrutura oceanográfica da região sudeste entre Cabo Frio (RJ) e Cabo de Santa Marta Grande (SC). Cien. Cult. 38(8): 14391450. São Paulo. 
Mesquita, A. R. 1994. Variações do nível do mar nas costas brasileiras. Afro-American Gloss News, 1: 3-4.

Mesquita, A. R. 1997. Marés, Circulação e Nivel do Mar na Costa Sudeste do Brasil. Documento preparado para a FUNDESPA. IOUPS, São Paulo.

Miranda, L. B.; Katsuragawa, M. 1991. Estrutura térmica na região sudeste do Brasil (outono/novembro de 1988). Pub. Esp. Inst. Oceanogr., 8: 1-14.

Moulinier, M. R. 1981. Foraminiferal biocenoses in na epicontinental sea of detrital sedimentation, the channel. In: Neale, J. W. \& Brasier, M. D. Microfossil from recent and fóssil shelf sea. Chichester: Ellis Horwood Ltda. p. 304-313.

Murray, J. W. 1991. Ecology and Paleoecology of Benthic Foraminifera. Longman, Horlow, 397p.

Neto, J. L. S. \& Nery, J. T. 2005. Variabilidade e mudanças climáticas no Brasil e seus impactos regionais. In: Souza, C. R. G.; Suguio, K.; Oliveira, A. M. S. e Oliveira, P. E. eds. Quaternário do Brasil. Ed. Holos , Ribeirão Preto, São Paulo. 378p.

Pawlowski, J.; Holzmann, M.; Nerney, C.; Fahrni, J.; Gooday, A. J.; Cedhagen, T.; Habura, A. e Bowser, S. S. 2003. The evolution of early Foraminifera. PNAS.

Peterson, R. \& Stramma, L. 1991. Upper-level circulation in the South Atlantic Ocean. Progress in Oceanography, 26(1): 1-73.

Petri, S. \& Vieira, E. M. 1975. Métodos de estudos paleoecológicos e as assembléias cenozóicas de foraminíferos de Caravelas, Bahia. Bolm. Inst. Geoc. 6:109-127. São Paulo.

Ponçano, W. L. 1985. Sedimentação atual aplicada a portos no Brasil. Dissertação (Mestrado). Instituto de Geociências, Universidade de São Paulo, 2v. 
Ponçano, W. L.; Carneiro, C. D. R.; Bistrich, C. A.; Almeida, F. F. M. e Prandini, L. 1981. Mapa geomorfolófgico do Estado de São Paulo. Instituto de Pesquisas Tecnológicas, São Paulo. 2v.

Rathburn, A. E.; Levin, L. A.; Held, Z. e Lohmann, K. C. 2000. Benthic foraminifera Associated with cold methane seeps on the Northern California margin: ecology and Stable isotopic composition. Marine Micropaleontology, 38: 247-266.

Reinhardt, E. G.; Patterson, R. T.; Schröder - Adams, C. 1994. Geoarchaelogy of the ancient harbor if Caesarea Maritma, Israel: evidence from sedimentology and paleoecology of benthic foraminifera. Journal of Foraminiferal Research, 24: 3748.

Rodrigues, S. C. 2006. Tafonomia de moluscos bivalves e braquiópodes das enseadas de Ubatuba e Picinguaba, norte do estado de São Paulo: implicações do uso de assinaturas tafonômicas no reconhecimento de gradientes ambientais. Tese de Doutoramento. São Paulo, IGc-USP.118 p.

Rodrigues, M.; Mahiques, M. M. e Tessler, M. G. 2002. Sedimentação atual nas enseadas de Ubatumirim e Picinguaba, região norte de Ubatuba, Estado de São Paulo, Brasil. Revista Brasileira de Oceanografia, 50: 27-45.

Sanches, T. M. 1992. Distribuição dos foraminíferos recentes na região de Ubatuba, São Paulo. Dissertação de mestrado. Universidade de São Paulo, Instituto Oceanográfico. 110p.

Schnitker, D. 1974. Ecotypic variation in Ammonia beccarii (Linne). Jour. Foram. Res., 4(4): 217-223, 1pl, 1 tab.

Schröder, C. J.; Scott, D. B. e Medioli, F. S. 1987. Can smaller benthic foraminifera be ignored in paleoenviromental analyses? J. Foram. Res., 4:101-110. 
Scott, D. B.; Schaffer, C. T.; Honig, C. e Younger, D. C. 1995. Temporal variations foraminiferal assemblage under or near aquaculture operations: documentation off impact history. Journal of Foraminiferal Research, 25(3): 224-235.

Scott, D. B.; Medioli, F. S.; Schafer, C. T. 2001. Monitoring in coastal environments using foraminifera and thecamoebian indicators. Cambridge: Cambridge University Press. 177p.

Sen Gupta, B. K. ed. 1999. Modern Foraminífera. Kluwer Academic Publishers, Norwell, MA, U.S.A. 371 p.

Sen Gupta, B. K.; Turner, R. E. e Rabalais, N. N. 1996. Seasonal oxygen depletion in continental-shelf of Louisiana: historical Record of benthic foraminifers. Geology, 24 (3): 227-230.

Sentelhas, P. C. \& Angelocci, L. R. 2007. Notas de aula LCE360 - Meteorologia Agrícola. ESALQ - USP.

Sharifi, A. R.; Croudace, I. W. e Austin, R. L. 1991. Benthic foraminiferids as pollution incators in Southamptom Water, southerm England, UK. Journal of Micropaleontology. 10(1), 109-113.

Shepard, F. P. \& Moore, D. G. 1954. Sedimentary environments differentiated by coarse fraction analysis. Bull. Am. Assoc. Petrol. Geol., 38(8): 1792-1802.

Silva, J. B.; Duleba, W.; Filippos, L. S.; Fonseca, P. P.; Mahiques, M. M. e Sonvesso, S. S. 2006. Holocene evolution of Flamengo and Fortaleza Bays, Ubatuba, Brazil, inferred from benthic foraminifera and sedimentological data. FORAMS 2006, Natal. 
Silva, J. B.; Duleba, W; Fonseca, P. P. e Mahiques, M. M. 2007a. Reconstituição Paleoambiental da Enseada do Flamengo com Base em Foraminíferos Bentônicos Holocênicos. Resumo XX Congresso Brasileiro de Paleontologia, Búzios, outubro de 2007.

Silva, J. B.; Duleba, W. e Mahiques, M. M. 2007b. Estudo Tafonômico de Foraminíferos da Enseada da Fortaleza, Ubatuba, São Paulo, Brasil. Resumo XX Congresso Brasileiro de Paleontologia, Búzios, outubro de 2007.

Silveira, I. C. A.; Schmidt, A. C. K.; Campos, E. J. D.; Godoi, S. S. \& Ikeda, Yoshimine. 2000. A Corrente do Brasil ao Largo da Costa Leste Brasileira. Rev. Bras. Oceanogr. 48(2):171-183.

Sonvesso, S. S. 2007. Variações na acumulação de material orgânica, ao lonogo do Holoceno, em sedimentos da região costeira de Ubatuba - São Paulo. Dissertação (Mestrado). Instituto Oceanográfico, Universidade de São Paulo.

Stein, R. 1991. Accumulation of organic carbon in marine sediments. Results from the DSDP/ODP, berlin, Springer-Verlag. 217p.

Sturrock, S. \& Murray, J. W. 1981. Comparison of low energy and high energy Marine middle shelf foraminiferal faunas; Celtic Sea and Eastern English Channel. In: NEALE, J.W. \& BRASIER, M.D. (Eds.). Microfossil from recent and fossil shelf seas London: Ellis Horwod, p.250-259.

Suguio, K. \& Martin, L. 1976. Mecanismo de Gênese das planícies sedimentares quaternárias do litoral do Estado de São Paulo. In: XXIX Congresso Brasileiro de Geologia, Anais, 1:295-305.

Suguio, K \& Martin, L. 1978. Formações Quaternárias Marinhas do Litoral Paulista e Sul Fluminense. In: Special Publication No1, International Symposium On Coastal Evolution In The Quaternary - The Brazilian National Working Group For The Igcp; Project 61, Instituto de Geociências da USP. São Paulo, 55 P. 
Suguio, K. \& Tessler, M. G. 1984. Planície de cordões litorâneos quaternários do Brasil: origem e nomenclatura. In: Lacerda, L. D.; Araújo, D. S. D.; Turcq, B. (eds). Restingas: origem, estrutura e processos. Pág. 15-25.

Suguio, K.; Martin, L.; Bittencourt, A. C. S. P.; Dominguez, J. M. L.; Flexor, J. M. e Azevedo, A. E. G. 1985. Flutuações do nível relativo do mar durante o Quaternário superior ao longo do litoral brasileiro e suas implicações na sedimentação costeira. Revista Brasileira de Geociências, 15: 273-286.

Suguio, K.; Angulo, R. J.; Carvalho, A. M.; Corrêa, I. C. S.; Tomazelli, L. J.; Willwock, J. A. e Vital, H. 2005. Paleoníveis do mar e paleolinhas de costa. In: Souza, C. R. G.; Suguio, K.; Oliveira, A. M. S. e Oliveira, P. E. eds. Quaternário do Brasil. Ed. Holos , Ribeirão Preto, São Paulo. 378p.

Teixeira, C. 1980. Estudo quantitativo da produção primária, clorofila-a e parâmetros abióticos em relação à variação temporal (lat. $23^{\circ} 30^{\prime} S$ - long. $45^{\circ} 06^{\prime} W$ ). Tese de Livre-docência. Universidade de São Paulo, Instituto Oceanográfico. 243p.

Teodoro, A. C. 2006. Estudos hidrogeoquímicos, sedimentológicos e de foraminíferos em áreas da baixada santista, S.P., submetidas à disposição oceânica de esgotos. Dissertação (Mestrado), USP Inst. Geol. São Paulo.

ter, Braak, C. J. F. 1988. CANOCO - A FORTRAN program for canonical community ordination [partial] [detrended] [canonical] correspondence analysis (version 2.1). Report LWA - 88 Wageningen, The Netherlands. Agricultural Mathematics Group, $95 \mathrm{p}$.

ter Braak, C. J. F, \& Smilauer, P. 2002. Canoco Reference Manual and User's Guide to Canoco for Windows: Software for Canonical Community Ordination (version 4.5). Microcomputer Power, Ithaca, NY, 500p. 
Tinoco, I. M. 1975. Estabelecimento e desenvolvimento da província biogeográfica das Índias Ocidentais. Universidade Federal de Pernambuco, Recife, PE. Arq. Mus. Nac., RJ. V.55.

Todd, R. \& Brönniman, P. 1957. Recent Foraminifera and Thecamoebina from the eastern Gulf of Paria. Cush. Found. Foram. Res., Publicação especial, 3:38.

Tomazelli, L. J. 1990. Contribuição aos estudos dos sistemas deposicionais holocênicos do nordeste da província costeira do Rio Grande do Sul, com ênfase no sistema eólico. Ph.D. Thesis, Universidade Federal do Rio Grande do Sul, 270p.

Tomazelli, L. J. Villwock, J. A.; Dillenburg, S. R.; Bachi, F. A. e Dehnhardt, B. A. 1998. Significance of present-day coastal erosion and marine transgression, Rio Grande do Sul, southern Brazil. Anais da Acad. Brasil. de Ciências, 70: 221-229.

Wan, X.; Lamolda, M. A.; Si, J. e Li, G. 2005. Foraminiferal stratigraphy of Late Cretaceous red beds in southern Tibet. Cretaceous Research, 26(1): 43-48.

Wentworth, C. R. 1922. A scale of grade and class terms for clastic sediments. Journal of Geology, 30: 377-392.

Williams, H. F. L. 1995. Foraminiferal record of recent environmental change: Mad Island Lake, Texas. Journal Foraminiferal Research, 25: 167-179.

Williams, D. E.; Hallock, P.; Talge, H. K.; Harney, J. N. e McRae, G. 1997. Responses of Amphistegina gibbosa populations in the Florida Keys (USA) to a multi-year stress event (1991 - 1992). Journal Foraminiferal Research, 27:264-270.

Wrightman, W. G.; Scott, D. B. e Medioli, F. S. 1994. Agglutinated foraminifera and thecamoebians from the Late Carboniferous Sydney coalfield, Nova Scotia: paleoecology, paleoenvironments and paleogeographical implications. Palaeogeography, Palaeoclimatology, Palaeoecology, 106:187-202. 
Yamane, M. 2003. Late Quaternary variations in water mass in the Shatsky Rise area, northwest Pacicc Ocean. Marine Micropaleontology, 48: 205-223.

Yanko, V.; Arnold, A. J. \& Parker, W. C. 1999. Effects of marine pollution on benthic Foraminifera. In: Gupta, B.Sed. 1999. Modern Foraminífera. Kluwer Academic Publishers, Norwell, MA, U.S.A. 371 p.

Ybert, J. P.; Bissa, W. M.; Catharino, E. L. M. e Kutner, M. 2003. Environmental and sea level variation on the southeastern Brazilian coast on Late Holocene with comment on prehistoric human occupation. Palaeogeography, Palaeoclimatology, Palaeoecology, 189: 11-24.

Yoshikazu, S. \& Massumoto, E. 2001. C/N ratios in a sediment core from Nakaumi Lagoon, Soutwest Japan - Usefulness as an organic source indicator. Geochemical Journal, 35:189-205.

Zhang, J.; Wang, P.; Li, Q.; Cheng, X.; Jin, H. \& Zhang, S. 2007. Western equatorial Pacific productivity and carbonate dissolution over the last $550 \mathrm{kyr}$ : Foraminiferal and nannofossil evidence from ODP Hole 807A. Marine Micropaleontology, 64: $121-140$.

www.google.com.br

www.litoralvirtual.com.br 
ANEXOS 
Tabela 5: Espécies de foraminíferos encontradas no testemunho UB1

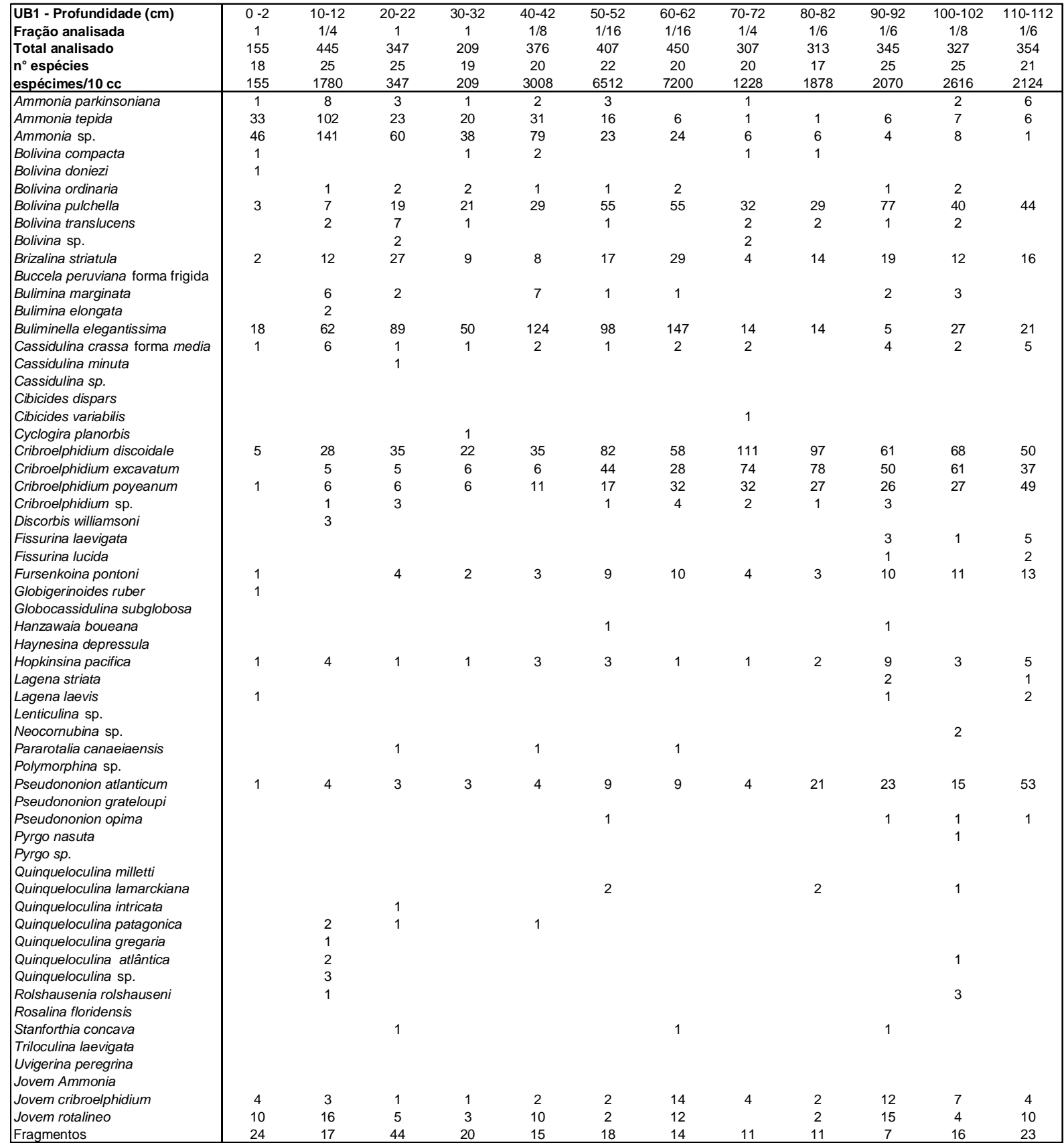


Tabela 5: Espécies de foraminíferos encontradas no testemunho UB1 (Continuação)

\begin{tabular}{|c|c|c|c|c|c|c|c|c|c|c|c|}
\hline $\begin{array}{l}\text { UB1 - Profundidade }(\mathrm{cm}) \\
\text { Fração analisada } \\
\text { Total analisado } \\
n^{\circ} \text { espécies } \\
\text { espécimes } 10 \mathrm{cc} \\
\end{array}$ & $\begin{array}{c}120-122 \\
1 / 6 \\
317 \\
19 \\
1902 \\
\end{array}$ & $\begin{array}{c}130-132 \\
1 / 6 \\
412 \\
27 \\
2472 \\
\end{array}$ & $\begin{array}{c}140-142 \\
1 / 6 \\
605 \\
28 \\
3630 \\
\end{array}$ & $\begin{array}{c}150-152 \\
1 / 6 \\
333 \\
24 \\
1998 \\
\end{array}$ & $\begin{array}{c}160-162 \\
1 / 8 \\
321 \\
30 \\
2568 \\
\end{array}$ & $\begin{array}{c}170-172 \\
1 / 16 \\
416 \\
25 \\
6656 \\
\end{array}$ & $\begin{array}{c}180-182 \\
1 / 8 \\
454 \\
28 \\
3632 \\
\end{array}$ & $\begin{array}{c}190-192 \\
1 / 8 \\
539 \\
32 \\
4312 \\
\end{array}$ & $\begin{array}{c}200-202 \\
1 / 2 \\
366 \\
26 \\
732 \\
\end{array}$ & $\begin{array}{c}210-212 \\
1 / 2 \\
451 \\
26 \\
902 \\
\end{array}$ & $\begin{array}{c}220-222 \\
1 \\
411 \\
31 \\
411 \\
\end{array}$ \\
\hline Ammonia parkinsoniana & & & & & 1 & & & & & & 1 \\
\hline Ammonia tepida & 3 & 1 & 5 & 4 & 8 & 26 & 11 & 18 & 4 & 19 & 9 \\
\hline Ammonia sp. & 7 & 9 & 15 & 9 & 16 & 40 & 32 & 55 & 30 & 34 & 36 \\
\hline $\begin{array}{l}\text { Bolivina compacta } \\
\text { Bolivina doniezi }\end{array}$ & 2 & & 1 & & $\begin{array}{l}2 \\
1\end{array}$ & 9 & 1 & 1 & 1 & & 3 \\
\hline Bolivina ordinaria & & 1 & 2 & 1 & 1 & 1 & 4 & 3 & 2 & 2 & 1 \\
\hline Bolivina pulchella & 44 & 113 & 120 & 81 & 93 & 39 & 29 & 35 & 26 & 77 & 39 \\
\hline Bolivina translucens & & 2 & & 2 & 2 & & 2 & 22 & 1 & 2 & 1 \\
\hline Bolivina sp. & & & 1 & 2 & & & & 1 & & & \\
\hline Brizalina striatula & 10 & 24 & 48 & 26 & 11 & 69 & 56 & 49 & 47 & 67 & 54 \\
\hline Buccela peruviana forma frigida & & & & & & & & 1 & & & 1 \\
\hline Bulimina marginata & & 1 & 1 & & 3 & 2 & 6 & 1 & 3 & 3 & \\
\hline Bulimina elongata & & & & 1 & 4 & 3 & 2 & 2 & 3 & & 1 \\
\hline Buliminella elegantissima & 24 & 21 & 48 & 23 & 10 & 85 & 81 & 81 & 71 & 33 & 29 \\
\hline Cassidulina crassa forma media & 2 & 9 & 18 & 15 & 3 & 18 & 27 & 12 & 10 & 16 & 9 \\
\hline Cassidulina minuta & & 1 & 1 & & 1 & & & 3 & & & \\
\hline Cassidulina sp. & & & & & & & & 1 & & & \\
\hline Cibicides dispars & & & 1 & & & 1 & 1 & & & & \\
\hline Cibicides variabilis & & & & 1 & & 2 & & & & 1 & 2 \\
\hline Cyclogira planorbis & & & & & 1 & & & & & & \\
\hline Cribroelphidium discoidale & 75 & 56 & 46 & 22 & 24 & 6 & 36 & 54 & 33 & 22 & 32 \\
\hline Cribroelphidium excavatum & 52 & 21 & 8 & 5 & 23 & 1 & 17 & 32 & 19 & 6 & 12 \\
\hline Cribroelphidium poyeanum & 25 & 36 & 85 & 28 & 26 & 29 & 15 & 20 & 14 & 33 & 29 \\
\hline Cribroelphidium sp. & & 1 & 1 & 1 & 2 & & 1 & 2 & 1 & & 2 \\
\hline Discorbis williamsoni & & & & 1 & & & 1 & & & & \\
\hline Fissurina laevigata & & 1 & 2 & & & & 1 & & & & \\
\hline Fissurina lucida & & & & & 1 & & & 3 & & & \\
\hline Fursenkoina pontoni & 5 & 8 & 27 & 12 & 22 & 14 & 12 & 37 & 19 & 29 & 21 \\
\hline Globigerinoides ruber & 1 & & & & & & & & 1 & & \\
\hline Globocassidulina subglobosa & & 1 & 1 & 1 & 1 & 3 & 1 & 1 & & 1 & \\
\hline Hanzawaia boueana & & & 1 & & & 1 & & & & & \\
\hline Haynesina depressula & & 1 & & & & & & & & & \\
\hline Hopkinsina pacifica & 5 & 10 & 18 & 11 & 3 & 12 & 19 & 32 & 17 & 15 & 6 \\
\hline Lagena striata & 1 & & 1 & & & & & 1 & & & \\
\hline Lagena laevis & & & & & & & & 1 & & & \\
\hline Lenticulina sp. & & & & & & & 1 & & & & \\
\hline Neocornubina sp. & 1 & 1 & 2 & & & & & & & & 2 \\
\hline Pararotalia canaeiaensis & & & & & & & & & 3 & 1 & 4 \\
\hline Polymorphina sp. & & & & & & & & & & & 1 \\
\hline Pseudononion atlanticum & 27 & 45 & 64 & 26 & 42 & 16 & 18 & 40 & 21 & 28 & 17 \\
\hline Pseudononion grateloupi & & & & & 2 & & & 1 & & & 1 \\
\hline Pseudononion opima & & 1 & & 1 & 1 & 1 & & & 1 & 2 & \\
\hline Pyrgo nasuta & & & & & & & & & & & 1 \\
\hline Pyrgo sp. & & & & & & & & 1 & & & \\
\hline Quinqueloculina milletti & & & & & & & 1 & & & 1 & \\
\hline Quinqueloculina lamarckiana & & & & & & 1 & 11 & & 2 & 7 & 11 \\
\hline Quinqueloculina intricata & & & & & & & & 1 & & & \\
\hline Quinqueloculina patagonica & & & & & 1 & & & & 1 & & 1 \\
\hline Quinqueloculina gregaria & & & & & & & & 1 & & & \\
\hline Quinqueloculina atlântica & & & & & & & & & & 1 & \\
\hline Quinqueloculina sp. & & 1 & & 1 & & & & 1 & & & \\
\hline Rolshausenia rolshauseni & & & & & & & & & & 1 & \\
\hline Rosalina floridensis & 1 & 1 & 1 & & & & & & & & 1 \\
\hline Stanforthia concava & & 1 & 1 & & 1 & 1 & 4 & & & 1 & \\
\hline Triloculina laevigata & & & & & & & & & & 1 & \\
\hline Uvigerina peregrina & & & & & & & & & 1 & & 2 \\
\hline Jovem Ammonia & & & & & & & & & & & \\
\hline Jovem cribroelphidium & 10 & 7 & 16 & 11 & 1 & 3 & 8 & 6 & 7 & 5 & 2 \\
\hline Jovem rotalineo & 5 & 16 & 37 & 17 & 9 & 19 & 15 & 10 & 4 & 9 & 28 \\
\hline Fragmentos & 17 & 22 & 33 & 31 & 5 & 14 & 41 & 10 & 24 & 34 & 52 \\
\hline
\end{tabular}


Tabela 7: Freqüência relativa de espécies de foraminíferos encontradas no testemunho UB1 - valores percentuais. Acima de 49\% - dominante. Entre 49-25\% - sub-dominante. Entre 25-5\% acessória. Abaixo de 5\% - rara.

\begin{tabular}{|c|c|c|c|c|c|c|c|c|c|c|c|c|}
\hline UB1 - Profundidade (cm) & $0-2$ & $10-12$ & $20-22$ & $30-32$ & $40-42$ & $50-52$ & $60-62$ & $70-72$ & $80-82$ & $90-92$ & $100-102$ & $110-112$ \\
\hline \multicolumn{13}{|l|}{\begin{tabular}{|l|}
$\mathrm{AC}$ \\
\end{tabular}} \\
\hline Ammonia parkinsoniana & 0,76 & 1,87 & 0,99 & 0,53 & 0,55 & 0,77 & 0,00 & 0,34 & 0,00 & 0,00 & 0,64 & 1,81 \\
\hline Ammonia tepida & 25,19 & 23,83 & 7,59 & 10,58 & 8,59 & 4,11 & 1,38 & 0,34 & 0,33 & 1,78 & 2,25 & 1,81 \\
\hline Ammonia sp. & 35,11 & 32,94 & 19,80 & 20,11 & 21,88 & 5,91 & 5,50 & 2,01 & 1,99 & 1,18 & 2,57 & 0,30 \\
\hline Cribroelphidium discoidale & 3,82 & 6,54 & 11,55 & 11,64 & 9,70 & 21,08 & 13,30 & 37,25 & 32,12 & 18,05 & 21,86 & 15,11 \\
\hline Cribroelphidium excavatum & 0,00 & 1,17 & 1,65 & 3,17 & 1,66 & 11,31 & 6,42 & 24,83 & 25,83 & 14,79 & 19,61 & 11,18 \\
\hline Cribroelphidium poyeanum & 0,76 & 1,40 & 1,98 & 3,17 & 3,05 & 4,37 & 7,34 & 10,74 & 8,94 & 7,69 & 8,68 & 14,80 \\
\hline Cribroelphidium sp. & 0,00 & 0,23 & 0,99 & 0,00 & 0,00 & 0,26 & 0,92 & 0,67 & 0,33 & 0,89 & 0,00 & 0,00 \\
\hline Pararotalia canaeiaensis & 0,00 & 0,00 & 0,33 & 0,00 & 0,28 & 0,00 & 0,23 & 0,00 & 0,00 & 0,00 & 0,00 & 0,00 \\
\hline Rolshauseni rolshauseni & 0,00 & 0,23 & 0,00 & 0,00 & 0,00 & 0,00 & 0,00 & 0,00 & 0,00 & 0,00 & 0,96 & 0,00 \\
\hline Total & 65,65 & 68,22 & 44,88 & 49,21 & 45,71 & 47,81 & 35,09 & 76,17 & 69,54 & 44,38 & 56,59 & 45,02 \\
\hline \multicolumn{13}{|l|}{ ACAS } \\
\hline Cassidulina crassa forma media & 0,76 & 1,40 & 0,33 & 0,53 & 0,55 & 0,26 & 0,46 & 0,67 & 0,00 & 1,18 & 0,64 & 1,51 \\
\hline \multicolumn{13}{|l|}{ AT } \\
\hline Buccela peruviana & 0,00 & 0,00 & 0,00 & 0,00 & 0,00 & 0,00 & 0,00 & 0,00 & 0,00 & 0,00 & 0,00 & 0,00 \\
\hline Globigerinoides ruber & 0,76 & 0,00 & 0,00 & 0,00 & 0,00 & 0,00 & 0,00 & 0,00 & 0,00 & 0,00 & 0,00 & 0,00 \\
\hline Globocassidulina subglobosa & 0,00 & 0,00 & 0,00 & 0,00 & 0,00 & 0,00 & 0,00 & 0,00 & 0,00 & 0,00 & 0,00 & 0,00 \\
\hline Lenticulina sp. & 0,00 & 0,00 & 0,00 & 0,00 & 0,00 & 0,00 & 0,00 & 0,00 & 0,00 & 0,00 & 0,00 & 0,00 \\
\hline Cassidulina minuta & 0,00 & 0,00 & 0,33 & 0,00 & 0,00 & 0,00 & 0,00 & 0,00 & 0,00 & 0,00 & 0,00 & 0,00 \\
\hline Cassidulina sp. & 0,00 & 0,00 & 0,00 & 0,00 & 0,00 & 0,00 & 0,00 & 0,00 & 0,00 & 0,00 & 0,00 & 0,00 \\
\hline Uvigerina peregrina & 0,00 & 0,00 & 0,00 & 0,00 & 0,00 & 0,00 & 0,00 & 0,00 & 0,00 & 0,00 & 0,00 & 0,00 \\
\hline Total & 0,76 & 0,00 & 0,33 & 0,00 & 0,00 & 0,00 & 0,00 & 0,00 & 0,00 & 0,00 & 0,00 & 0,00 \\
\hline \multicolumn{13}{|l|}{ M.O. } \\
\hline Bolivina compacta & 0,76 & 0,00 & 0,00 & 0,53 & 0,55 & 0,00 & 0,00 & 0,34 & 0,33 & 0,00 & 0,00 & 0,00 \\
\hline Bolivina doniezi & 0,76 & 0,00 & 0,00 & 0,00 & 0,00 & 0,00 & 0,00 & 0,00 & 0,00 & 0,00 & 0,00 & 0,00 \\
\hline Bolivina ordinaria & 0,00 & 0,23 & 0,66 & 1,06 & 0,28 & 0,26 & 0,46 & 0,00 & 0,00 & 0,30 & 0,64 & 0,00 \\
\hline Bolivina pulchella & 2,29 & 1,64 & 6,27 & 11,11 & 8,03 & 14,14 & 12,61 & 10,74 & 9,60 & 22,78 & 12,86 & 13,29 \\
\hline Bolivina translucens & 0,00 & 0,47 & 2,31 & 0,53 & 0,00 & 0,26 & 0,00 & 0,67 & 0,66 & 0,30 & 0,64 & 0,00 \\
\hline Bolivina sp. & 0,00 & 0,00 & 0,66 & 0,00 & 0,00 & 0,00 & 0,00 & 0,67 & 0,00 & 0,00 & 0,00 & 0,00 \\
\hline Brizalina striatula & 1,53 & 2,80 & 8,91 & 4,76 & 2,22 & 4,37 & 6,65 & 1,34 & 4,64 & 5,62 & 3,86 & 4,83 \\
\hline Bulimina marginata & 0,00 & 1,40 & 0,66 & 0,00 & 1,94 & 0,26 & 0,23 & 0,00 & 0,00 & 0,59 & 0,96 & 0,00 \\
\hline Bulimina elongata & 0,00 & 0,47 & 0,00 & 0,00 & 0,00 & 0,00 & 0,00 & 0,00 & 0,00 & 0,00 & 0,00 & 0,00 \\
\hline Buliminella elegantissima & 13,74 & 14,49 & 29,37 & 26,46 & 34,35 & 25,19 & 33,72 & 4,70 & 4,64 & 1,48 & 8,68 & 6,34 \\
\hline Fursenkoina pontoni & 0,76 & 0,00 & 1,32 & 1,06 & 0,83 & 2,31 & 2,29 & 1,34 & 0,99 & 2,96 & 3,54 & 3,93 \\
\hline Hopkinsina pacifica & 0,76 & 0,93 & 0,33 & 0,53 & 0,83 & 0,77 & 0,23 & 0,34 & 0,66 & 2,66 & 0,96 & 1,51 \\
\hline Pseudononion atlanticum & 0,76 & 0,93 & 0,99 & 1,59 & 1,11 & 2,31 & 2,06 & 1,34 & 6,95 & 6,80 & 4,82 & 16,01 \\
\hline Pseudononion grateloupi & 0,00 & 0,00 & 0,00 & 0,00 & 0,00 & 0,00 & 0,00 & 0,00 & 0,00 & 0,00 & 0,00 & 0,00 \\
\hline Pseudononion opima & 0,00 & 0,00 & 0,00 & 0,00 & 0,00 & 0,26 & 0,00 & 0,00 & 0,00 & 0,30 & 0,32 & 0,30 \\
\hline Stanforthia concava & 0,00 & 0,00 & 0,33 & 0,00 & 0,00 & 0,00 & 0,23 & 0,00 & 0,00 & 0,30 & 0,00 & 0,00 \\
\hline Total & 21,37 & 23,36 & 51,82 & 47,62 & 50,14 & 50,13 & 58,49 & 21,48 & 28,48 & 44,08 & 37,30 & 46,22 \\
\hline \multicolumn{13}{|l|}{\begin{tabular}{|l|} 
Ambiente Rico em Oxigênio \\
\end{tabular}} \\
\hline Cibicides dispars & 0,00 & 0,00 & 0,00 & 0,00 & 0,00 & 0,00 & 0,00 & 0,00 & 0,00 & 0,00 & 0,00 & 0,00 \\
\hline Cibicides variabilis & 0,00 & 0,00 & 0,00 & 0,00 & 0,00 & 0,00 & 0,00 & 0,34 & 0,00 & 0,00 & 0,00 & 0,00 \\
\hline Discorbis williamsoni & 0,00 & 0,70 & 0,00 & 0,00 & 0,00 & 0,00 & 0,00 & 0,00 & 0,00 & 0,00 & 0,00 & 0,00 \\
\hline Fissurina laevigata & 0,00 & 0,00 & 0,00 & 0,00 & 0,00 & 0,00 & 0,00 & 0,00 & 0,00 & 0,89 & 0,32 & 1,51 \\
\hline Fissurina lucida & 0,00 & 0,00 & 0,00 & 0,00 & 0,00 & 0,00 & 0,00 & 0,00 & 0,00 & 0,30 & 0,00 & 0,60 \\
\hline Hanzawaia boueana & 0,00 & 0,00 & 0,00 & 0,00 & 0,00 & 0,26 & 0,00 & 0,00 & 0,00 & 0,30 & 0,00 & 0,00 \\
\hline Lagena striata & 0,00 & 0,00 & 0,00 & 0,00 & 0,00 & 0,00 & 0,00 & 0,00 & 0,00 & 0,59 & 0,00 & 0,30 \\
\hline Lagena laevis & 0,76 & 0,00 & 0,00 & 0,00 & 0,00 & 0,00 & 0,00 & 0,00 & 0,00 & 0,30 & 0,00 & 0,60 \\
\hline Neocornubina sp. & 0,00 & 0,00 & 0,00 & 0,00 & 0,00 & 0,00 & 0,00 & 0,00 & 0,00 & 0,00 & 0,64 & 0,00 \\
\hline Pyrgo nasuta & 0,00 & 0,00 & 0,00 & 0,00 & 0,00 & 0,00 & 0,00 & 0,00 & 0,00 & 0,00 & 0,32 & 0,00 \\
\hline Pyrgo sp. & 0,00 & 0,00 & 0,00 & 0,00 & 0,00 & 0,00 & 0,00 & 0,00 & 0,00 & 0,00 & 0,00 & 0,00 \\
\hline Quinqueloculina milletti & 0,00 & 0,00 & 0,00 & 0,00 & 0,00 & 0,00 & 0,00 & 0,00 & 0,00 & 0,00 & 0,00 & 0,00 \\
\hline Quinqueloculina lamarckiana & 0,00 & 0,00 & 0,00 & 0,00 & 0,00 & 0,51 & 0,00 & 0,00 & 0,66 & 0,00 & 0,32 & 0,00 \\
\hline Quinqueloculina intricata & 0,00 & 0,00 & 0,33 & 0,00 & 0,00 & 0,00 & 0,00 & 0,00 & 0,00 & 0,00 & 0,00 & 0,00 \\
\hline Quinqueloculina patagonica & 0,00 & 0,47 & 0,33 & 0,00 & 0,28 & 0,00 & 0,00 & 0,00 & 0,00 & 0,00 & 0,00 & 0,00 \\
\hline Quinqueloculina gregaria & 0,00 & 0,23 & 0,00 & 0,00 & 0,00 & 0,00 & 0,00 & 0,00 & 0,00 & 0,00 & 0,00 & 0,00 \\
\hline Quinqueloculina atlântica & 0,00 & 0,47 & 0,00 & 0,00 & 0,00 & 0,00 & 0,00 & 0,00 & 0,00 & 0,00 & 0,32 & 0,00 \\
\hline Quinqueloculina sp. & 0,00 & 0,70 & 0,00 & 0,00 & 0,00 & 0,00 & 0,00 & 0,00 & 0,00 & 0,00 & 0,00 & 0,00 \\
\hline $\begin{array}{l}\text { Rosalina floridensis } \\
\text { Ron }\end{array}$ & 0,00 & 0,00 & 0,00 & 0,00 & 0,00 & 0,00 & 0,00 & 0,00 & 0,00 & 0,00 & 0,00 & 0,00 \\
\hline Triloculina laevigata & 0,00 & 0,00 & 0,00 & 0,00 & 0,00 & 0,00 & 0,00 & 0,00 & 0,00 & 0,00 & 0,00 & 0,00 \\
\hline Total & 0,76 & 2,57 & 0,66 & 0,00 & 0,28 & 0,77 & 0,00 & 0,34 & 0,66 & 2,37 & 1,93 & 3,02 \\
\hline \multicolumn{13}{|l|}{ Outras Espécies } \\
\hline Cyclogira planorbis & 0,00 & 0,00 & 0,00 & 0,53 & 0,00 & 0,00 & 0,00 & 0,00 & 0,00 & 0,00 & 0,00 & 0,00 \\
\hline Haynesina depressula & 0,00 & 0,00 & 0,00 & 0,00 & 0,00 & 0,00 & 0,00 & 0,00 & 0,00 & 0,00 & 0,00 & 0,00 \\
\hline Polymorphina sp. & 0,00 & 0,00 & 0,00 & 0,00 & 0,00 & 0,00 & 0,00 & 0,00 & 0,00 & 0,00 & 0,00 & 0,00 \\
\hline Jovem Ammonia & 0,00 & 0,00 & 0,00 & 0,00 & 0,00 & 0,00 & 0,00 & 0,00 & 0,00 & 0,00 & 0,00 & 0,00 \\
\hline Jovem cribroelphidium & 3,05 & 0,70 & 0,33 & 0,53 & 0,55 & 0,51 & 3,21 & 1,34 & 0,66 & 3,55 & 2,25 & 1,21 \\
\hline Jovem rotalineo & 7,63 & 3,74 & 1,65 & 1,59 & 2,77 & 0,51 & 2,75 & 0,00 & 0,66 & 4,44 & 1,29 & 3,02 \\
\hline
\end{tabular}


Tabela 7: Freqüência relativa de espécies de foraminíferos encontradas no testemunho UB1 - valores percentuais. Acima de 49\% - dominante. Entre 49-25\% - sub-dominante. Entre 25$5 \%$ - acessória. Abaixo de 5\% - rara. (continuação)

\begin{tabular}{|c|c|c|c|c|c|c|c|c|c|c|c|}
\hline UB1 - Profundidade (cm) & $120-122$ & $130-132$ & $140-142$ & $150-152$ & $160-162$ & $170-172$ & $180-182$ & 190-192 & $200-202$ & $210-212$ & $220-222$ \\
\hline $\mathbf{A C}$ & & & & & & & & & & & \\
\hline Ammonia parkinsoniana & 0,00 & 0,00 & 0,00 & 0,00 & 0,32 & 0,00 & 0,00 & 0,00 & 0,00 & 0,00 & 0,28 \\
\hline Ammonia tepida & 1,00 & 0,26 & 0,87 & 1,32 & 2,53 & 6,47 & 2,66 & 3,40 & 1,17 & 4,56 & 2,51 \\
\hline Ammonia sp. & 2,33 & 2,31 & 2,62 & 2,98 & 5,06 & 9,95 & 7,75 & 10,40 & 8,77 & 8,15 & 10,03 \\
\hline Cribroelphidium discoidale & 25,00 & 14,36 & 8,04 & 7,28 & 7,59 & 1,49 & 8,72 & 10,21 & 9,65 & 5,28 & 8,91 \\
\hline Cribroelphidium excavatum & 17,33 & 5,38 & 1,40 & 1,66 & 7,28 & 0,25 & 4,12 & 6,05 & 5,56 & 1,44 & 3,34 \\
\hline Cribroelphidium poyeanum & 8,33 & 9,23 & 14,86 & 9,27 & 8,23 & 7,21 & 3,63 & 3,78 & 4,09 & 7,91 & 8,08 \\
\hline Cribroelphidium sp. & 0,00 & 0,26 & 0,17 & 0,33 & 0,63 & 0,00 & 0,24 & 0,38 & 0,29 & 0,00 & 0,56 \\
\hline Pararotalia canaeiaensis & 0,00 & 0,00 & 0,00 & 0,00 & 0,00 & 0,00 & 0,00 & 0,00 & 0,88 & 0,24 & 1,11 \\
\hline Rolshauseni rolshauseni & 0,00 & 0,00 & 0,00 & 0,00 & 0,00 & 0,00 & 0,00 & 0,00 & 0,00 & 0,24 & 0,00 \\
\hline Total & 54,00 & 31,79 & 27,97 & 22,85 & 31,65 & 25,37 & 27,12 & 34,22 & 30,41 & 27,82 & 34,82 \\
\hline \multicolumn{12}{|l|}{ ACAS } \\
\hline Cassidulina crassa forma media & 0,67 & 2,31 & 3,15 & 4,97 & 0,95 & 4,48 & 6,54 & 2,27 & 2,92 & 3,84 & 2,51 \\
\hline \multicolumn{12}{|l|}{ AT } \\
\hline Buccela peruviana & 0,00 & 0,00 & 0,00 & 0,00 & 0,00 & 0,00 & 0,00 & 0,19 & 0,00 & 0,00 & 0,28 \\
\hline Globigerinoides ruber & 0,33 & 0,00 & 0,00 & 0,00 & 0,00 & 0,00 & 0,00 & 0,00 & 0,29 & 0,00 & 0,00 \\
\hline Globocassidulina subglobosa & 0,00 & 0,26 & 0,17 & 0,33 & 0,32 & 0,75 & 0,24 & 0,19 & 0,00 & 0,24 & 0,00 \\
\hline Lenticulina sp. & 0,00 & 0,00 & 0,00 & 0,00 & 0,00 & 0,00 & 0,24 & 0,00 & 0,00 & 0,00 & 0,00 \\
\hline Cassidulina minuta & 0,00 & 0,26 & 0,17 & 0,00 & 0,32 & 0,00 & 0,00 & 0,57 & 0,00 & 0,00 & 0,00 \\
\hline Cassidulina sp. & 0,00 & 0,00 & 0,00 & 0,00 & 0,00 & 0,00 & 0,00 & 0,19 & 0,00 & 0,00 & 0,00 \\
\hline Uvigerina peregrina & 0,00 & 0,00 & 0,00 & 0,00 & 0,00 & 0,00 & 0,00 & 0,00 & 0,29 & 0,00 & 0,56 \\
\hline Total & 0,33 & 0,51 & 0,35 & 0,33 & 0,63 & 0,75 & 0,48 & 1,13 & 0,58 & 0,24 & 0,84 \\
\hline \multicolumn{12}{|l|}{ M.O. } \\
\hline Bolivina compacta & 0,67 & 0,00 & 0,17 & 0,00 & 0,63 & 2,24 & 0,24 & 0,19 & 0,29 & 0,00 & 0,84 \\
\hline Bolivina doniezi & 0,00 & 0,00 & 0,00 & 0,00 & 0,32 & 0,00 & 0,00 & 0,00 & 0,00 & 0,00 & 0,00 \\
\hline Bolivina ordinaria & 0,00 & 0,26 & 0,35 & 0,33 & 0,32 & 0,25 & 0,97 & 0,57 & 0,58 & 0,48 & 0,28 \\
\hline Bolivina pulchella & 14,67 & 28,97 & 20,98 & 26,82 & 29,43 & 9,70 & 7,02 & 6,62 & 7,60 & 18,47 & 10,86 \\
\hline Bolivina translucens & 0,00 & 0,51 & 0,00 & 0,66 & 0,63 & 0,00 & 0,48 & 4,16 & 0,29 & 0,48 & 0,28 \\
\hline Bolivina sp. & 0,00 & 0,00 & 0,17 & 0,66 & 0,00 & 0,00 & 0,00 & 0,19 & 0,00 & 0,00 & 0,00 \\
\hline Brizalina striatula & 3,33 & 6,15 & 8,39 & 8,61 & 3,48 & 17,16 & 13,56 & 9,26 & 13,74 & 16,07 & 15,04 \\
\hline Bulimina marginata & 0,00 & 0,26 & 0,17 & 0,00 & 0,95 & 0,50 & 1,45 & 0,19 & 0,88 & 0,72 & 0,00 \\
\hline Bulimina elongata & 0,00 & 0,00 & 0,00 & 0,33 & 1,27 & 0,75 & 0,48 & 0,38 & 0,88 & 0,00 & 0,28 \\
\hline Buliminella elegantissima & 8,00 & 5,38 & 8,39 & 7,62 & 3,16 & 21,14 & 19,61 & 15,31 & 20,76 & 7,91 & 8,08 \\
\hline Fursenkoina pontoni & 1,67 & 2,05 & 4,72 & 3,97 & 6,96 & 3,48 & 2,91 & 6,99 & 5,56 & 6,95 & 5,85 \\
\hline Hopkinsina pacifica & 1,67 & 2,56 & 3,15 & 3,64 & 0,95 & 2,99 & 4,60 & 6,05 & 4,97 & 3,60 & 1,67 \\
\hline Pseudononion atlanticum & 9,00 & 11,54 & 11,19 & 8,61 & 13,29 & 3,98 & 4,36 & 7,56 & 6,14 & 6,71 & 4,74 \\
\hline Pseudononion grateloupi & 0,00 & 0,00 & 0,00 & 0,00 & 0,63 & 0,00 & 0,00 & 0,19 & 0,00 & 0,00 & 0,28 \\
\hline Pseudononion opima & 0,00 & 0,26 & 0,00 & 0,33 & 0,32 & 0,25 & 0,00 & 0,00 & 0,29 & 0,48 & 0,00 \\
\hline Stanforthia concava & 0,00 & 0,26 & 0,17 & 0,00 & 0,32 & 0,25 & 0,97 & 0,00 & 0,00 & 0,24 & 0,00 \\
\hline Total & 39,00 & 58,21 & 57,87 & 61,59 & 62,66 & 62,69 & 56,66 & 57,66 & 61,99 & 62,11 & 48,19 \\
\hline \multicolumn{12}{|l|}{ Ambiente Rico em Oxigênio } \\
\hline Cibicides dispars & 0,00 & 0,00 & 0,17 & 0,00 & 0,00 & 0,25 & 0,24 & 0,00 & 0,00 & 0,00 & 0,00 \\
\hline Cibicides variabilis & 0,00 & 0,00 & 0,00 & 0,33 & 0,00 & 0,50 & 0,00 & 0,00 & 0,00 & 0,24 & 0,56 \\
\hline Discorbis williamsoni & 0,00 & 0,00 & 0,00 & 0,33 & 0,00 & 0,00 & 0,24 & 0,00 & 0,00 & 0,00 & 0,00 \\
\hline Fissurina laevigata & 0,00 & 0,26 & 0,35 & 0,00 & 0,00 & 0,00 & 0,24 & 0,00 & 0,00 & 0,00 & 0,00 \\
\hline Fissurina lucida & 0,00 & 0,00 & 0,00 & 0,00 & 0,32 & 0,00 & 0,00 & 0,57 & 0,00 & 0,00 & 0,00 \\
\hline Hanzawaia boueana & 0,00 & 0,00 & 0,17 & 0,00 & 0,00 & 0,25 & 0,00 & 0,00 & 0,00 & 0,00 & 0,00 \\
\hline Lagena striata & 0,33 & 0,00 & 0,17 & 0,00 & 0,00 & 0,00 & 0,00 & 0,19 & 0,00 & 0,00 & 0,00 \\
\hline Lagena laevis & 0,00 & 0,00 & 0,00 & 0,00 & 0,00 & 0,00 & 0,00 & 0,19 & 0,00 & 0,00 & 0,00 \\
\hline Neocornubina sp. & 0,33 & 0,26 & 0,35 & 0,00 & 0,00 & 0,00 & 0,00 & 0,00 & 0,00 & 0,00 & 0,56 \\
\hline Pyrgo nasuta & 0,00 & 0,00 & 0,00 & 0,00 & 0,00 & 0,00 & 0,00 & 0,00 & 0,00 & 0,00 & 0,28 \\
\hline Pyrgo sp. & 0,00 & 0,00 & 0,00 & 0,00 & 0,00 & 0,00 & 0,00 & 0,19 & 0,00 & 0,00 & 0,00 \\
\hline Quinqueloculina milletti & 0,00 & 0,00 & 0,00 & 0,00 & 0,00 & 0,00 & 0,24 & 0,00 & 0,00 & 0,24 & 0,00 \\
\hline Quinqueloculina lamarckiana & 0,00 & 0,00 & 0,00 & 0,00 & 0,00 & 0,25 & 2,66 & 0,00 & 0,58 & 1,68 & 3,06 \\
\hline Quinqueloculina intricata & 0,00 & 0,00 & 0,00 & 0,00 & 0,00 & 0,00 & 0,00 & 0,19 & 0,00 & 0,00 & 0,00 \\
\hline Quinqueloculina patagonica & 0,00 & 0,00 & 0,00 & 0,00 & 0,32 & 0,00 & 0,00 & 0,00 & 0,29 & 0,00 & 0,28 \\
\hline Quinqueloculina gregaria & 0,00 & 0,00 & 0,00 & 0,00 & 0,00 & 0,00 & 0,00 & 0,19 & 0,00 & 0,00 & 0,00 \\
\hline Quinqueloculina atlântica & 0,00 & 0,00 & 0,00 & 0,00 & 0,00 & 0,00 & 0,00 & 0,00 & 0,00 & 0,24 & 0,00 \\
\hline Quinqueloculina sp. & 0,00 & 0,26 & 0,00 & 0,33 & 0,00 & 0,00 & 0,00 & 0,19 & 0,00 & 0,00 & 0,00 \\
\hline Rosalina floridensis & 0,33 & 0,26 & 0,17 & 0,00 & 0,00 & 0,00 & 0,00 & 0,00 & 0,00 & 0,00 & 0,28 \\
\hline Triloculina laevigata & 0,00 & 0,00 & 0,00 & 0,00 & 0,00 & 0,00 & 0,00 & 0,00 & 0,00 & 0,24 & 0,00 \\
\hline Total & 1,00 & 1,03 & 1,40 & 0,99 & 0,63 & 1,24 & 3,63 & 1,70 & 0,88 & 2,64 & 5,01 \\
\hline \multicolumn{12}{|l|}{ Outras Espécies } \\
\hline Cyclogira planorbis & 0,00 & 0,00 & 0,00 & 0,00 & 0,32 & 0,00 & 0,00 & 0,00 & 0,00 & 0,00 & 0,00 \\
\hline Haynesina depressula & 0,00 & 0,26 & 0,00 & 0,00 & 0,00 & 0,00 & 0,00 & 0,00 & 0,00 & 0,00 & 0,00 \\
\hline Polymorphina sp. & 0,00 & 0,00 & 0,00 & 0,00 & 0,00 & 0,00 & 0,00 & 0,00 & 0,00 & 0,00 & 0,28 \\
\hline Jovem Ammonia & 0,00 & 0,00 & 0,00 & 0,00 & 0,00 & 0,00 & 0,00 & 0,00 & 0,00 & 0,00 & 0,00 \\
\hline Jovem cribroelphidium & 3,33 & 1,79 & 2,80 & 3,64 & 0,32 & 0,75 & 1,94 & 1,13 & 2,05 & 1,20 & 0,56 \\
\hline Jovem rotalineo & 1,67 & 4,10 & 6,47 & 5,63 & 2,85 & 4,73 & 3,63 & 1,89 & 1,17 & 2,16 & 7,80 \\
\hline
\end{tabular}


Tabela 8: Espécies de foraminíferos encontradas no testemunho UB3

\begin{tabular}{|c|c|c|c|c|c|c|c|c|c|c|c|c|}
\hline UB3- Profundidade (cm) & $0-2$ & $10-12$ & $20-22$ & $30-32$ & $40-42$ & $50-52$ & $60-62$ & $70-72$ & $80-82$ & $90-92$ & $100-102$ & $\overline{110-112}$ \\
\hline Fração analisada & $1 / 64$ & $1 / 32$ & $1 / 64$ & $1 / 8$ & $1 / 16$ & $1 / 64$ & $1 / 32$ & $1 / 64$ & $1 / 16$ & $1 / 128$ & 1 & $1 / 32$ \\
\hline Total analisado & 409 & 451 & 493 & 599 & 685 & 475 & 485 & 400 & 517 & 319 & 7 & 351 \\
\hline$n^{\circ}$ espécies & 41 & 43 & 38 & 42 & 47 & 35 & 37 & 33 & 39 & 33 & 2 & 40 \\
\hline espécimes/10 cc & 26176 & 14432 & 31552 & 4792 & 10960 & 30400 & 15520 & 25600 & 8272 & 40832 & 7 & 11232 \\
\hline Ammonia parkinsoniana & 1 & 3 & 1 & & 1 & 1 & & & & & & \\
\hline Ammonia tepida & 6 & 21 & 21 & 10 & 7 & 6 & 3 & 7 & 4 & 4 & & 6 \\
\hline Ammonia sp. & 16 & 36 & 25 & 22 & 21 & 12 & 14 & 7 & 24 & 13 & & 10 \\
\hline \multicolumn{13}{|l|}{ Amphycorina scalaris } \\
\hline Bolivina compacta & 6 & 1 & 1 & 1 & 1 & & & 1 & & 1 & & 1 \\
\hline Bolivina ordinaria & 2 & 1 & & 3 & 1 & & & & 1 & & & \\
\hline Bolivina pulchella & 44 & 31 & 39 & 61 & 80 & 62 & 59 & 50 & 71 & 29 & & 50 \\
\hline \multicolumn{13}{|l|}{ Bolivina translucens } \\
\hline Bolivina sp. & 1 & 1 & & & & & & & & & 2 & \\
\hline Brizalina striatula & 20 & 32 & 44 & 37 & 41 & 45 & 37 & 29 & 25 & 37 & & 12 \\
\hline Buccela peruviana & & 2 & 1 & 2 & & & & & & & & \\
\hline Bulimina marginata & 12 & 32 & 26 & 29 & 25 & 10 & 23 & 14 & 3 & 7 & & 2 \\
\hline Bulimina elongata & 1 & 4 & & & & & & 1 & 1 & & & 2 \\
\hline Buliminella elegantissima & 6 & 2 & 7 & 7 & 12 & 5 & & 4 & 3 & 4 & & \\
\hline Cancris sagra & 1 & & & 2 & 1 & 1 & 1 & & & & & \\
\hline Cassidulina crassa forma media & 69 & 39 & 54 & 95 & 94 & 70 & 81 & 84 & 90 & 51 & & 34 \\
\hline Cassidulina minuta & 17 & 4 & 7 & 7 & 1 & & & & 2 & 2 & & \\
\hline Cassidulina sp. & & 1 & 4 & & & & & & & & & \\
\hline Cibicides dispars & 3 & 2 & 5 & 5 & 7 & 1 & 1 & 4 & 7 & 2 & & 3 \\
\hline Cibicides variabilis & & 1 & & 1 & 2 & 1 & 2 & 1 & & 2 & & \\
\hline Cibicides sp. & & & 1 & 2 & & & & & & & & \\
\hline Cribroelphidium discoidale & 6 & 43 & 24 & 21 & 31 & 31 & 18 & 15 & 23 & 11 & & 24 \\
\hline Cribroelphidium excavatum & & 12 & 7 & 9 & 7 & 18 & 9 & 7 & 16 & 7 & & 5 \\
\hline Cribroelphidium poyeanum & 11 & 13 & 13 & 19 & 36 & 20 & 21 & 12 & 12 & 13 & & 12 \\
\hline Cribroelphidium sp. & 1 & 1 & & & & 1 & & & & & & \\
\hline Discorbis williamsoni & 34 & 25 & 70 & 72 & 65 & 44 & 42 & 40 & 47 & 34 & & 33 \\
\hline Eponides repandus & & 2 & 2 & 1 & 3 & & 3 & 1 & & 2 & & \\
\hline Fissurina laevigata & 4 & 3 & 2 & 2 & 6 & 11 & 8 & 3 & 7 & 4 & & 10 \\
\hline Fissurina lucida & & & & & & 1 & 2 & & 1 & 2 & & 2 \\
\hline Fissurina sp. & & 1 & & 1 & & & & & & & & 1 \\
\hline Fursenkoina pontoni & 3 & 6 & 3 & 3 & 5 & 2 & 4 & 9 & 7 & 8 & & 2 \\
\hline Glandulina sp. & & & 1 & & 2 & & & & & & & \\
\hline Globigerinoides ruber & 1 & & & 1 & & & & & 2 & & & 4 \\
\hline \multicolumn{12}{|l|}{ Globulina gibba } & \\
\hline Guttulina plancii & & & & & & & & & 1 & & & \\
\hline Hanzawaia boueana & 15 & 10 & 13 & 17 & 29 & 11 & 13 & 9 & 20 & 5 & 1 & 16 \\
\hline Hopkinsina pacifica & 2 & & 1 & & & 1 & & 1 & & 1 & & \\
\hline Lagena striata & & & & & 4 & & & 1 & 3 & & & \\
\hline Lagena laevis & & & & 1 & 1 & & 2 & 2 & 3 & 1 & & 2 \\
\hline Lagena sp. & & & & & & & 1 & & & & & \\
\hline Lenticulina sp. & 1 & 2 & & & & & & & & & & 1 \\
\hline Lobatula lobatula & & & & & & & 1 & & & & & \\
\hline Miliammina fusca & & & & & 1 & & 1 & & & & & 1 \\
\hline Neocornubina sp. & & & & 4 & 4 & & 1 & & 5 & 2 & & 1 \\
\hline \multicolumn{13}{|l|}{ Oolina caudigera } \\
\hline Oolina hexagona & 1 & & & & 1 & & & & & 1 & & 1 \\
\hline Oolina lineata & & & & & & & & & & & & \\
\hline Oolina mello & & & & & 1 & & & & & & & \\
\hline Oolina vilardeboana & & & & & 1 & & & & & & & 1 \\
\hline Oolina sp. & & & 1 & & & & & & & & & \\
\hline Orthomorphina sp. & & & & & 1 & & & & & & & \\
\hline $\begin{array}{l}\text { Pararotalia canaeiaensis } \\
\text { Polvmorphina sp. }\end{array}$ & 15 & 11 & 19 & 26 & $\begin{array}{c}35 \\
2\end{array}$ & 14 & 14 & 15 & 23 & 17 & & 16 \\
\hline Pseudononion atlanticum & 10 & 20 & 26 & 26 & 28 & 24 & 32 & 19 & 28 & 15 & & 22 \\
\hline Pseudononion grateloupi & & & & & & & & & & & & \\
\hline Pseudononion opima & & & & & & 2 & & & 2 & & & 2 \\
\hline Pyrgo nasuta & 1 & 2 & & & 1 & 2 & 1 & 3 & 2 & 3 & & 5 \\
\hline Pyrgo sp. & 1 & 1 & & & 1 & & & & & & & \\
\hline Quinqueloculina intricata & & 1 & & & & & & & 1 & & & \\
\hline Quinqueloculina milletti & 2 & 2 & 1 & 2 & 11 & 1 & 2 & & & 2 & & 8 \\
\hline Quinqueloculina lamarckiana & 2 & 9 & 6 & 15 & 22 & 15 & 6 & 12 & 6 & 7 & & 7 \\
\hline Quinqueloculina patagonica & 1 & 1 & 1 & 1 & 3 & 2 & 1 & 1 & 1 & 3 & & 1 \\
\hline Quinqueloculina cf. polygona & & & & & & & & & & & & \\
\hline Quinqueloculina atlantica & 1 & 1 & 1 & 1 & 4 & 5 & 2 & & 1 & & & 2 \\
\hline Quinqueloculina sp. & 1 & 2 & 2 & 5 & 5 & 3 & 2 & 1 & 2 & 1 & & 3 \\
\hline Rolshausenia rolshauseni & & & & 1 & & & & & & & & \\
\hline Rosalina floridensis & & 1 & 1 & 4 & 5 & 1 & 5 & 3 & 3 & & & 5 \\
\hline Spiroloculina sp. & & & & & & & & & 1 & & & 1 \\
\hline Stanforthia concava & 4 & 2 & 2 & 1 & 1 & 4 & 3 & 2 & 3 & & & 2 \\
\hline Uvigerina bifurcata & & & & 1 & & & & & & & & \\
\hline Uvigerina peregrina & 12 & 12 & 8 & 24 & 12 & 22 & 32 & 19 & 15 & 9 & & 4 \\
\hline Jovem rotalineo & 6 & 9 & 7 & 15 & 24 & 8 & 13 & 11 & 20 & 7 & & 29 \\
\hline Jovem cribroelphidium & 9 & 6 & 3 & 7 & 4 & 7 & 2 & 1 & 4 & & & 3 \\
\hline Fragmentos & 58 & 40 & 40 & 25 & 33 & 11 & 22 & 11 & 27 & 12 & 4 & 17 \\
\hline
\end{tabular}


Tabela 8: Espécies de foraminíferos encontradas no testemunho UB3 (continuação)

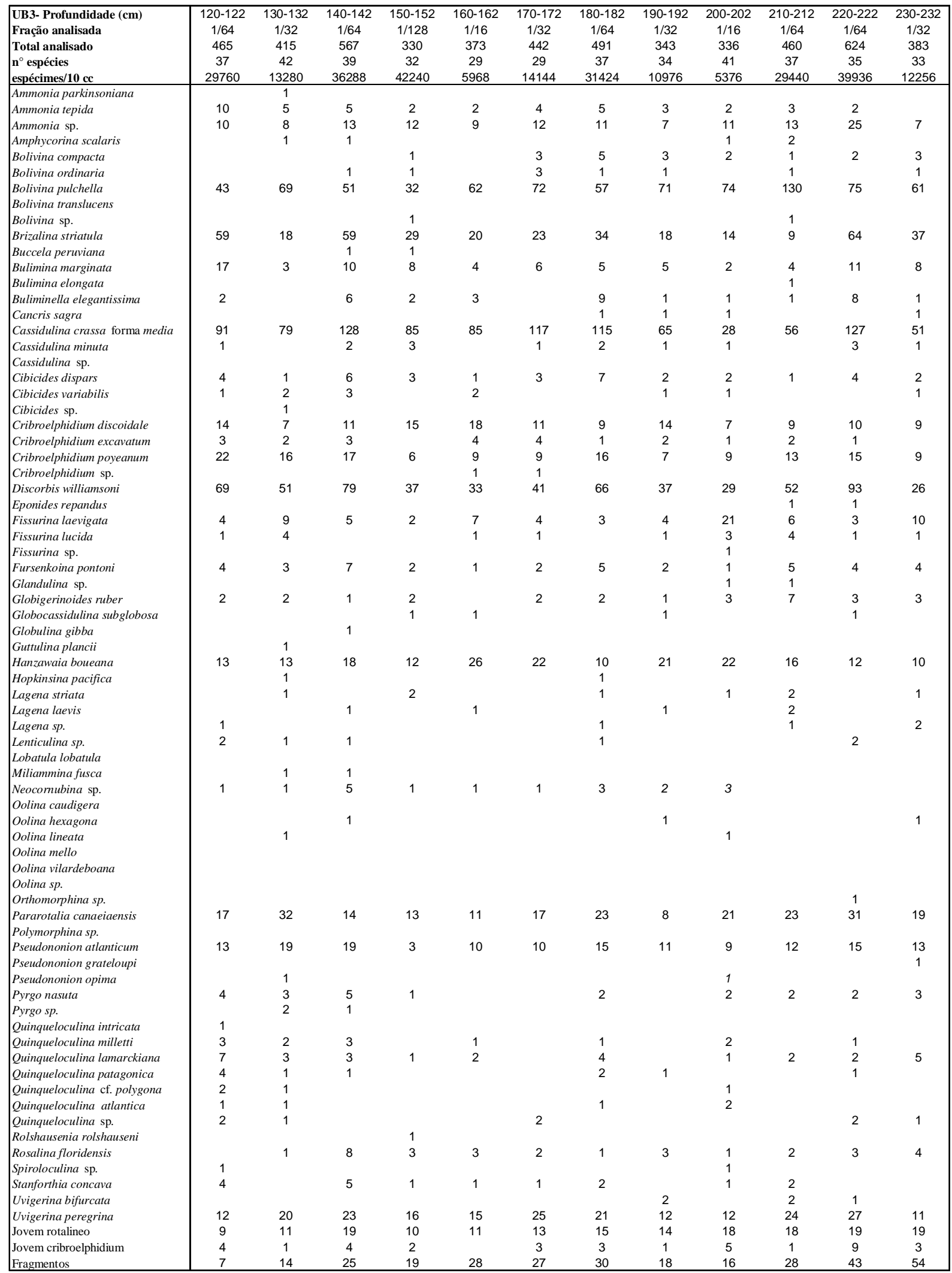


Tabela 8: Espécies de foraminíferos encontradas no testemunho UB3 (continuação)

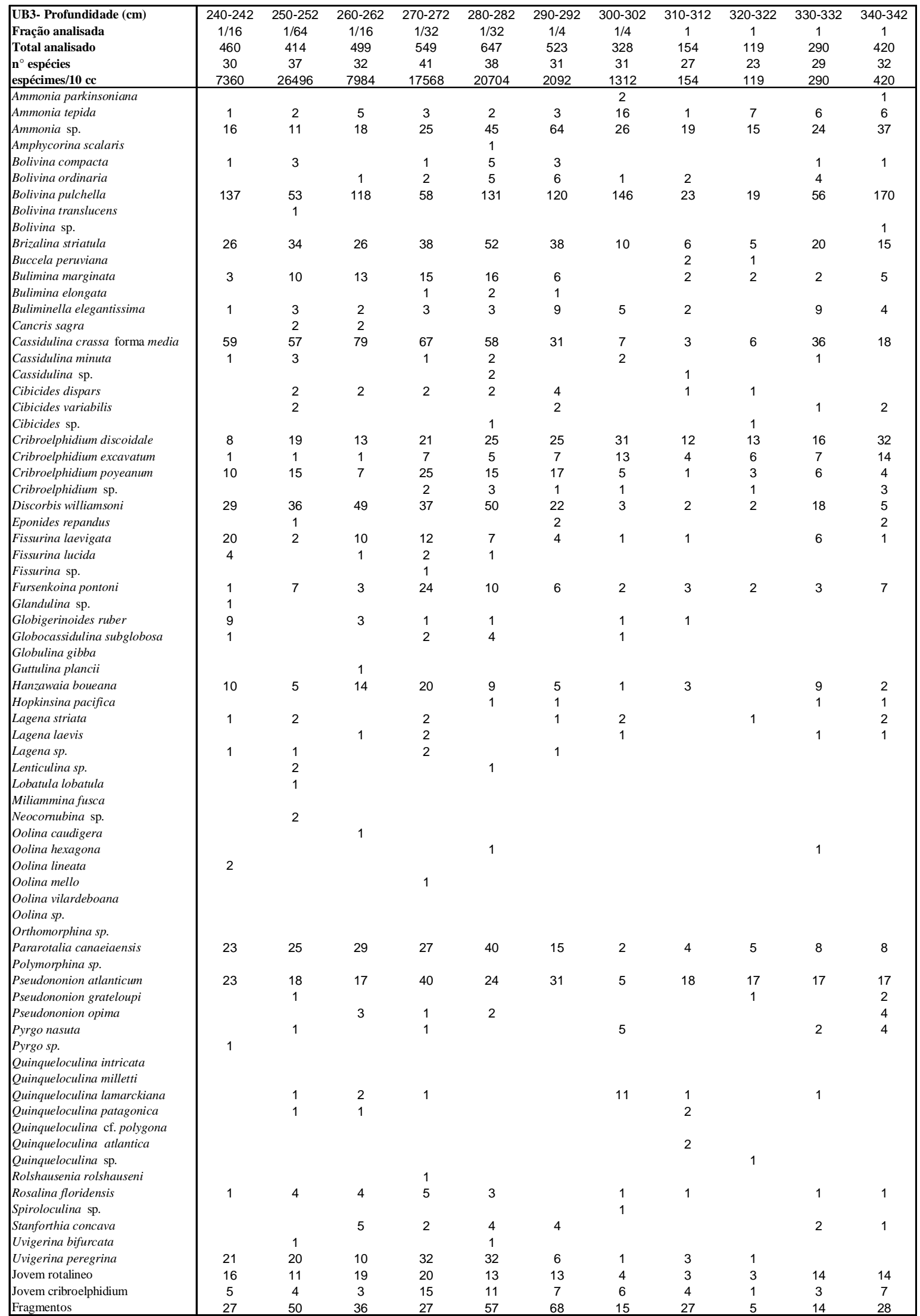


Tabela 10: Frequiência relativa de espécies de foraminíferos encontradas no testemunho UB3 - valores percentuais. Acima de 49\% - dominante. Entre 49-25\% - sub-dominante. Entre 25-5\% acessória. Abaixo de 5\% - rara.

\begin{tabular}{|c|c|c|c|c|c|c|c|c|c|c|c|c|}
\hline UB3 - Profundidade (cm) & $0-2$ & $10-12$ & $20-22$ & $30-32$ & $40-42$ & $50-52$ & $60-62$ & $70-72$ & $80-82$ & $90-92$ & $100-102$ & $110-112$ \\
\hline $\mathrm{AC}$ & & & & & & & & & & & & \\
\hline Ammonia parkinsoniana & 0,28 & 0,73 & 0,22 & 0,00 & 0,15 & 0,22 & 0,00 & 0,00 & 0,00 & 0,00 & 0,00 & 0,00 \\
\hline Ammonia tepida & 1,71 & 5,11 & 4,64 & 1,74 & 1,07 & 1,29 & 0,65 & 1,80 & 0,82 & 1,30 & 0,00 & 1,73 \\
\hline Ammonia sp. & 4,56 & 8,76 & 5,52 & 3,83 & 3,22 & 2,59 & 3,02 & 1,80 & 4,90 & 4,23 & 0,00 & 2,89 \\
\hline Cribroelphidium discoidale & 1,71 & 10,46 & 5,30 & 3,66 & 4,75 & 6,68 & 3,89 & 3,86 & 4,69 & 3,58 & 0,00 & 6,94 \\
\hline Cribroelphidium excavatum & 0,00 & 2,92 & 1,55 & 1,57 & 1,07 & 3,88 & 1,94 & 1,80 & 3,27 & 2,28 & 0,00 & 1,45 \\
\hline Cribroelphidium poyeanum & 3,13 & 3,16 & 2,87 & 3,31 & 5,52 & 4,31 & 4,54 & 3,08 & 2,45 & 4,23 & 0,00 & 3,47 \\
\hline Cribroelphidium sp. & 0,28 & 0,24 & 0,00 & 0,00 & 0,00 & 0,22 & 0,00 & 0,00 & 0,00 & 0,00 & 0,00 & 0,00 \\
\hline Pararotalia cananeiaensis & 4,27 & 2,68 & 4,19 & 4,53 & 5,37 & 3,02 & 3,02 & 3,86 & 4,69 & 5,54 & 0,00 & 4,62 \\
\hline Rolshauseni rolshauseni & 0,00 & 0,00 & 0,00 & 0,17 & 0,00 & 0,00 & 0,00 & 0,00 & 0,00 & 0,00 & 0,00 & 0,00 \\
\hline Total & 15,95 & 34,06 & 24,28 & 18,82 & 21,17 & 22,20 & 17,06 & 16,20 & 20,82 & 21,17 & 0,00 & 21,10 \\
\hline ACAS & & & & & & & & & & & & \\
\hline Cassidulina crassa forma media & 19,66 & 9,49 & 11,92 & 16,55 & 14,42 & 15,09 & 17,49 & 21,59 & 18,37 & 16,61 & 0,00 & 9,83 \\
\hline Uvigerina bifurcata & 0,00 & 0,00 & 0,00 & 0,17 & 0,00 & 0,00 & 0,00 & 0,00 & 0,00 & 0,00 & 0,00 & 0,00 \\
\hline Total & 19,66 & 9,49 & 11,92 & 16,72 & 14,42 & 15,09 & 17,49 & 21,59 & 18,37 & 16,61 & 0,00 & 9,83 \\
\hline$\overline{A T}$ & & & & & & & & & & & & \\
\hline Buccela peruviana & 0,00 & 0,49 & 0,22 & 0,35 & 0,00 & 0,00 & 0,00 & 0,00 & 0,00 & 0,00 & 0,00 & 0,00 \\
\hline Globigerinoides ruber & 0,28 & 0,00 & 0,00 & 0,17 & 0,00 & 0,00 & 0,00 & 0,00 & 0,41 & 0,00 & 0,00 & 1,16 \\
\hline Globocassidulina subglobosa & 0,57 & 0,00 & 0,66 & 1,74 & 0,31 & 0,00 & 0,22 & 0,00 & 0,00 & 0,00 & 0,00 & 0,00 \\
\hline Lenticulina sp. & 0,28 & 0,49 & 0,00 & 0,00 & 0,00 & 0,00 & 0,00 & 0,00 & 0,00 & 0,00 & 0,00 & 0,29 \\
\hline Cassidulina minuta & 4,84 & 0,97 & 1,55 & 1,22 & 0,15 & 0,00 & 0,00 & 0,00 & 0,41 & 0,65 & 0,00 & 0,00 \\
\hline Cassidulina sp. & 0,00 & 0,24 & 0,88 & 0,00 & 0,00 & 0,00 & 0,00 & 0,00 & 0,00 & 0,00 & 0,00 & 0,00 \\
\hline Uvigerina peregrina & 3,42 & 2,92 & 1,77 & 4,18 & 1,84 & 4,74 & 6,91 & 4,88 & 3,06 & 2,93 & 0,00 & 1,16 \\
\hline Total & 13,11 & 13,87 & 10,82 & 12,72 & 6,13 & 6,90 & 12,10 & 8,74 & 4,69 & 5,86 & 0,00 & 3,76 \\
\hline M.O. & & & & & & & & & & & & \\
\hline Bolivina compacta & 1,71 & 0,24 & 0,22 & 0,17 & 0,15 & 0,00 & 0,00 & 0,26 & 0,00 & 0,33 & 0,00 & 0,29 \\
\hline Bolivina ordinaria & 0,57 & 0,24 & 0,00 & 0,52 & 0,15 & 0,00 & 0,00 & 0,00 & 0,20 & 0,00 & 0,00 & 0,00 \\
\hline Bolivina pulchella & 12,54 & 7,54 & 8,61 & 10,63 & 12,27 & 13,36 & 12,74 & 12,85 & 14,49 & 9,45 & 0,00 & 14,45 \\
\hline Bolivina translucens & 0,00 & 0,00 & 0,00 & 0,00 & 0,00 & 0,00 & 0,00 & 0,00 & 0,00 & 0,00 & 0,00 & 0,00 \\
\hline Bolivina sp. & 0,28 & 0,24 & 0,00 & 0,00 & 0,00 & 0,00 & 0,00 & 0,00 & 0,00 & 0,00 & 66,67 & 0,00 \\
\hline Brizalina stiatula & 5,70 & 7,79 & 9,71 & 6,45 & 6,29 & 9,70 & 7,99 & 7,46 & 5,10 & 12,05 & 0,00 & 3,47 \\
\hline Bulimina elongata & 0,28 & 0,97 & 0,00 & 0,00 & 0,00 & 0,00 & 0,00 & 0,26 & 0,20 & 0,00 & 0,00 & 0,58 \\
\hline Bulimina marginata & 3,42 & 7,79 & 5,74 & 5,05 & 3,83 & 2,16 & 4,97 & 3,60 & 0,61 & 2,28 & 0,00 & 0,58 \\
\hline Buliminella elegantissima & 0,85 & 1,46 & 0,66 & 0,52 & 0,77 & 0,43 & 0,86 & 2,31 & 1,43 & 2,61 & 0,00 & 0,58 \\
\hline Fursenkoina pontoni & 0,57 & 0,00 & 0,22 & 0,00 & 0,00 & 0,22 & 0,00 & 0,26 & 0,00 & 0,33 & 0,00 & 0,00 \\
\hline Hopkinsina pacifica & 2,85 & 4,87 & 5,74 & 4,53 & 4,29 & 5,60 & 6,91 & 4,88 & 6,12 & 4,89 & 0,00 & 6,94 \\
\hline Pseudononion atlanticum & 2,85 & 4,87 & 5,74 & 4,53 & 4,29 & 5,17 & 6,91 & 4,88 & 5,71 & 4,89 & 0,00 & 6,36 \\
\hline Pseudononion grateloupi & 0,00 & 0,00 & 0,00 & 0,00 & 0,00 & 0,00 & 0,00 & 0,00 & 0,00 & 0,00 & 0,00 & 0,00 \\
\hline Pseudononion opima & 0,00 & 0,00 & 0,00 & 0,00 & 0,00 & 0,43 & 0,00 & 0,00 & 0,41 & 0,00 & 0,00 & 0,58 \\
\hline Stanforthia concava & 1,14 & 0,49 & 0,44 & 0,17 & 0,15 & 0,86 & 0,65 & 0,51 & 0,61 & 0,00 & 0,00 & 0,58 \\
\hline Total & 31,62 & 32,12 & 32,89 & 29,27 & 29,75 & 33,41 & 34,13 & 33,42 & 29,39 & 33,22 & 66,67 & 27,46 \\
\hline Ambiente Rico em Oxigênio & & & & & & & & & & & & \\
\hline Cancris sagra & 0,28 & 0,00 & 0,00 & 0,35 & 0,15 & 0,22 & 0,22 & 0,00 & 0,00 & 0,00 & 0,00 & 0,00 \\
\hline Cibicides dispars & 0,85 & 0,49 & 1,10 & 0,87 & 1,07 & 0,22 & 0,22 & 1,03 & 1,43 & 0,65 & 0,00 & 0,87 \\
\hline Cibicides variabilis & 0,00 & 0,24 & 0,00 & 0,17 & 0,31 & 0,22 & 0,43 & 0,26 & 0,00 & 0,65 & 0,00 & 0,00 \\
\hline Cibicides sp. & 0,00 & 0,00 & 0,22 & 0,35 & 0,00 & 0,00 & 0,00 & 0,00 & 0,00 & 0,00 & 0,00 & 0,00 \\
\hline Discorbis williamsoni & 9,69 & 6,08 & 15,45 & 12,54 & 9,97 & 9,48 & 9,07 & 10,28 & 9,59 & 11,07 & 0,00 & 9,54 \\
\hline Eponides repandus & 0,00 & 0,49 & 0,44 & 0,17 & 0,46 & 0,00 & 0,65 & 0,26 & 0,00 & 0,65 & 0,00 & 0,00 \\
\hline Fissurina laevigata & 1,14 & 0,73 & 0,44 & 0,35 & 0,92 & 2,37 & 1,73 & 0,77 & 1,43 & 1,30 & 0,00 & 2,89 \\
\hline Fissurina lucida & 0,00 & 0,00 & 0,00 & 0,00 & 0,00 & 0,22 & 0,43 & 0,00 & 0,20 & 0,65 & 0,00 & 0,58 \\
\hline Fissurina sp. & 0,00 & 0,24 & 0,00 & 0,17 & 0,00 & 0,00 & 0,00 & 0,00 & 0,00 & 0,00 & 0,00 & 0,29 \\
\hline Guttullina plancii & 0,00 & 0,00 & 0,00 & 0,00 & 0,00 & 0,00 & 0,00 & 0,00 & 0,20 & 0,00 & 0,00 & 0,00 \\
\hline Hanzawaia boueana & 4,27 & 2,43 & 2,87 & 2,96 & 4,45 & 2,37 & 2,81 & 2,31 & 4,08 & 1,63 & 33,33 & 4,62 \\
\hline Lagena striata & 0,00 & 0,00 & 0,00 & 0,00 & 0,61 & 0,00 & 0,00 & 0,26 & 0,61 & 0,00 & 0,00 & 0,00 \\
\hline Lagena laevis & 0,00 & 0,00 & 0,00 & 0,17 & 0,15 & 0,00 & 0,43 & 0,51 & 0,61 & 0,33 & 0,00 & 0,58 \\
\hline Lagena sp. & 0,00 & 0,00 & 0,00 & 0,00 & 0,00 & 0,00 & 0,22 & 0,00 & 0,00 & 0,00 & 0,00 & 0,00 \\
\hline Lobatula lobatula & 0,00 & 0,00 & 0,00 & 0,00 & 0,00 & 0,00 & 0,22 & 0,00 & 0,00 & 0,00 & 0,00 & 0,00 \\
\hline Miliamina fusca & 0,00 & 0,00 & 0,00 & 0,00 & 0,15 & 0,00 & 0,22 & 0,00 & 0,00 & 0,00 & 0,00 & 0,29 \\
\hline Neocornubina sp. & 0,00 & 0,00 & 0,00 & 0,70 & 0,61 & 0,00 & 0,22 & 0,00 & 1,02 & 0,65 & 0,00 & 0,29 \\
\hline Oolina hexagona & 0,28 & 0,00 & 0,00 & 0,00 & 0,15 & 0,00 & 0,00 & 0,00 & 0,00 & 0,33 & 0,00 & 0,29 \\
\hline Pyrgo nasuta & 0,28 & 0,49 & 0,00 & 0,00 & 0,15 & 0,43 & 0,22 & 0,77 & 0,41 & 0,98 & 0,00 & 1,45 \\
\hline Pyrgo sp. & 0,28 & 0,24 & 0,00 & 0,00 & 0,15 & 0,00 & 0,00 & 0,00 & 0,00 & 0,00 & 0,00 & 0,00 \\
\hline Quinqueloculina intricata & 0,00 & 0,24 & 0,00 & 0,00 & 0,00 & 0,00 & 0,00 & 0,00 & 0,20 & 0,00 & 0,00 & 0,00 \\
\hline Quinqueloculina milletti & 0,57 & 0,49 & 0,22 & 0,35 & 1,69 & 0,22 & 0,43 & 0,00 & 0,00 & 0,65 & 0,00 & 2,31 \\
\hline Quinqueloculina lamarckiana & 0,57 & 2,19 & 1,32 & 2,61 & 3,37 & 3,23 & 1,30 & 3,08 & 1,22 & 2,28 & 0,00 & 2,02 \\
\hline Quinqueloculina patagonica & 0,28 & 0,24 & 0,22 & 0,17 & 0,46 & 0,43 & 0,22 & 0,26 & 0,20 & 0,98 & 0,00 & 0,29 \\
\hline Quinqueloculina cf. polygona & 0,00 & 0,00 & 0,00 & 0,00 & 0,00 & 0,00 & 0,00 & 0,00 & 0,00 & 0,00 & 0,00 & 0,00 \\
\hline Quinqueloculina atlantica & 0,28 & 0,24 & 0,22 & 0,17 & 0,61 & 1,08 & 0,43 & 0,00 & 0,20 & 0,00 & 0,00 & 0,58 \\
\hline Quinqueloculina sp. & 0,28 & 0,49 & 0,44 & 0,87 & 0,77 & 0,65 & 0,43 & 0,26 & 0,41 & 0,33 & 0,00 & 0,87 \\
\hline Rosalina floridensis & 0,00 & 0,00 & 0,00 & 0,00 & 0,00 & 0,00 & 0,00 & 0,00 & 0,20 & 0,00 & 0,00 & 0,29 \\
\hline Spiroloculina sp. & 0,28 & 0,00 & 0,22 & 0,00 & 0,46 & 0,00 & 0,00 & 0,00 & 0,00 & 0,33 & 0,00 & 0,58 \\
\hline Total & 20,23 & 18,00 & 24,28 & 24,56 & 28,07 & 21,77 & 21,81 & 23,14 & 24,08 & 25,73 & 33,33 & 30,64 \\
\hline \begin{tabular}{|l|} 
Outras espécies \\
\end{tabular} & & & & & & & & & & & & \\
\hline Amphycorina scalaris & 0,00 & 0,00 & 0,00 & 0,00 & 0,00 & 0,00 & 0,00 & 0,00 & 0,00 & 0,00 & 0,00 & 0,00 \\
\hline Glandulina sp. & 0,00 & 0,00 & 0,22 & 0,00 & 0,31 & 0,00 & 0,00 & 0,00 & 0,00 & 0,00 & 0,00 & 0,00 \\
\hline Globulina gibba & 0,00 & 0,00 & 0,00 & 0,00 & 0,00 & 0,00 & 0,00 & 0,00 & 0,00 & 0,00 & 0,00 & 0,00 \\
\hline Oolina caudigera & 0,00 & 0,00 & 0,00 & 0,00 & 0,00 & 0,00 & 0,00 & 0,00 & 0,00 & 0,00 & 0,00 & 0,00 \\
\hline Oolina lineata & 0,00 & 0,00 & 0,00 & 0,00 & 0,00 & 0,00 & 0,00 & 0,00 & 0,00 & 0,00 & 0,00 & 0,00 \\
\hline Oolina mello & 0,00 & 0,00 & 0,00 & 0,00 & 0,15 & 0,00 & 0,00 & 0,00 & 0,00 & 0,00 & 0,00 & 0,00 \\
\hline Oolina vilardeboana & 0,00 & 0,00 & 0,00 & 0,00 & 0,15 & 0,00 & 0,00 & 0,00 & 0,00 & 0,00 & 0,00 & 0,29 \\
\hline Oolina sp. & 0,00 & 0,00 & 0,22 & 0,00 & 0,00 & 0,00 & 0,00 & 0,00 & 0,00 & 0,00 & 0,00 & 0,00 \\
\hline Orthomorphina sp. & 0,00 & 0,00 & 0,00 & 0,00 & 0,15 & 0,00 & 0,00 & 0,00 & 0,00 & 0,00 & 0,00 & 0,00 \\
\hline Polymorphina sp. & 0,00 & 0,00 & 0,00 & 0,00 & 0,31 & 0,00 & 0,00 & 0,00 & 0,00 & 0,00 & 0,00 & 0,00 \\
\hline Jovem rotalineo & 1,71 & 2,19 & 1,55 & 2,61 & 3,68 & 1,72 & 2,81 & 2,83 & 4,08 & 2,28 & 0,00 & 8,38 \\
\hline Jovem Cribroelphidium & 2,56 & 1,46 & 0,66 & 1,22 & 0,61 & 1,51 & 0,43 & 0,26 & 0,82 & 0,00 & 0,00 & 0,87 \\
\hline
\end{tabular}


Tabela 10: Frequiência relativa de espécies de foraminíferos encontradas no testemunho UB3 - valores percentuais. Acima de 49\% - dominante. Entre 49-25\% - sub-dominante. Entre 25-5\% acessória. Abaixo de 5\% - rara. (continuação)

\begin{tabular}{|c|c|c|c|c|c|c|c|c|c|c|c|c|}
\hline UB1 - Profundidade (cm) & $120-122$ & $130-132$ & $140-142$ & $150-152$ & $160-162$ & $170-172$ & $180-182$ & $190-192$ & $200-202$ & $210-212$ & $220-222$ & $230-232$ \\
\hline $\mathrm{AC}$ & & & & & & & & & & & & \\
\hline Ammonia parkinsoniana & 0,00 & 0,25 & 0,00 & 0,00 & 0,00 & 0,00 & 0,00 & 0,00 & 0,00 & 0,00 & 0,00 & 0,00 \\
\hline Ammonia tepida & 2,18 & 1,25 & 0,92 & 0,64 & 0,58 & 0,96 & 1,08 & 0,92 & 0,63 & 0,69 & 0,34 & 0,00 \\
\hline Ammonia sp. & 2,18 & 2,00 & 2,40 & 3,86 & 2,61 & 2,89 & 2,39 & 2,15 & 3,44 & 3,01 & 4,30 & 2,13 \\
\hline Cribroelphidium discoidale & 3,06 & 1,75 & 2,03 & 4,82 & 5,22 & 2,65 & 1,95 & 4,31 & 2,19 & 2,08 & 1,72 & 2,74 \\
\hline Cribroelphidium excavatum & 0,66 & 0,50 & 0,55 & 0,00 & 1,16 & 0,96 & 0,22 & 0,62 & 0,31 & 0,46 & 0,17 & 0,00 \\
\hline Cribroelphidium poyeanum & 4,80 & 3,99 & 3,14 & 1,93 & 2,61 & 2,17 & 3,47 & 2,15 & 2,81 & 3,01 & 2,58 & 2,74 \\
\hline Cribroelphidium sp. & 0,00 & 0,00 & 0,00 & 0,00 & 0,29 & 0,24 & 0,00 & 0,00 & 0,00 & 0,00 & 0,00 & 0,00 \\
\hline Pararotalia cananeiaensis & 3,71 & 7,98 & 2,58 & 4,18 & 3,19 & 4,10 & 4,99 & 2,46 & 6,56 & 5,32 & 5,34 & 5,78 \\
\hline Rolshauseni rolshauseni & 0,00 & 0,00 & 0,00 & 0,32 & 0,00 & 0,00 & 0,00 & 0,00 & 0,00 & 0,00 & 0,00 & 0,00 \\
\hline Total & 16,59 & 17,71 & 11,62 & 15,76 & 15,65 & 13,98 & 14,10 & 12,62 & 15,94 & 14,58 & 14,46 & 13,37 \\
\hline ACAS & & & & & & & & & & & & \\
\hline Cassidulina crassa forma media & 19,87 & 19,70 & 23,62 & 27,33 & 24,64 & 28,19 & 24,95 & 20,00 & 8,75 & 12,96 & 21,86 & 15,50 \\
\hline Uvigerina bifurcata & 0,00 & 0,00 & 0,00 & 0,00 & 0,00 & 0,00 & 0,00 & 0,62 & 0,00 & 0,46 & 0,17 & 0,00 \\
\hline Total & 19,87 & 19,70 & 23,62 & 27,33 & 24,64 & 28,19 & 24,95 & 20,62 & 8,75 & 13,43 & 22,03 & 15,50 \\
\hline AT & & & & & & & & & & & & \\
\hline Buccela peruviana & 0,00 & 0,00 & 0,18 & 0,32 & 0,00 & 0,00 & 0,00 & 0,00 & 0,00 & 0,00 & 0,00 & 0,00 \\
\hline Globigerinoides ruber & 0,44 & 0,50 & 0,18 & 0,64 & 0,00 & 0,48 & 0,43 & 0,31 & 0,94 & 1,62 & 0,52 & 0,91 \\
\hline Globocassidulina subglobosa & 0,00 & 0,00 & 0,00 & 0,32 & 0,29 & 0,00 & 0,00 & 0,31 & 0,00 & 0,00 & 0,17 & 0,00 \\
\hline Lenticulina sp. & 0,44 & 0,25 & 0,18 & 0,00 & 0,00 & 0,00 & 0,22 & 0,00 & 0,00 & 0,00 & 0,34 & 0,00 \\
\hline Cassidulina minuta & 0,22 & 0,00 & 0,37 & 0,96 & 0,00 & 0,24 & 0,43 & 0,31 & 0,31 & 0,00 & 0,52 & 0,30 \\
\hline Cassidulina sp. & 0,00 & 0,00 & 0,00 & 0,00 & 0,00 & 0,00 & 0,00 & 0,00 & 0,00 & 0,00 & 0,00 & 0,00 \\
\hline Uvigerina peregrina & 2,62 & 4,99 & 4,24 & 5,14 & 4,35 & 6,02 & 4,56 & 3,69 & 3,75 & 5,56 & 4,65 & 3,34 \\
\hline Total & 7,42 & 6,48 & 7,01 & 9,97 & 5,80 & 8,19 & 6,72 & 6,15 & 5,63 & 8,33 & 8,09 & 6,99 \\
\hline M.o. & & & & & & & & & & & & \\
\hline Bolivina compacta & 0,00 & 0,00 & 0,00 & 0,32 & 0,00 & 0,72 & 1,08 & 0,92 & 0,63 & 0,23 & 0,34 & 0,91 \\
\hline Bolivina ordinaria & 0,00 & 0,00 & 0,18 & 0,32 & 0,00 & 0,72 & 0,22 & 0,31 & 0,00 & 0,23 & 0,00 & 0,30 \\
\hline Bolivina pulchella & 9,39 & 17,21 & 9,41 & 10,29 & 17,97 & 17,35 & 12,36 & 21,85 & 23,13 & 30,09 & 12,91 & 18,54 \\
\hline Bolivina translucens & 0,00 & 0,00 & 0,00 & 0,00 & 0,00 & 0,00 & 0,00 & 0,00 & 0,00 & 0,00 & 0,00 & 0,00 \\
\hline Bolivina sp. & 0,00 & 0,00 & 0,00 & 0,32 & 0,00 & 0,00 & 0,00 & 0,00 & 0,00 & 0,23 & 0,00 & 0,00 \\
\hline Brizalina stiatula & 12,88 & 4,49 & 10,89 & 9,32 & 5,80 & 5,54 & 7,38 & 5,54 & 4,38 & 2,08 & 11,02 & 11,25 \\
\hline Bulimina elongata & 0,00 & 0,00 & 0,00 & 0,00 & 0,00 & 0,00 & 0,00 & 0,00 & 0,00 & 0,23 & 0,00 & 0,00 \\
\hline Bulimina marginata & 3,71 & 0,75 & 1,85 & 2,57 & 1,16 & 1,45 & 1,08 & 1,54 & 0,63 & 0,93 & 1,89 & 2,43 \\
\hline Buliminella elegantissima & 0,87 & 0,75 & 1,29 & 0,64 & 0,29 & 0,48 & 1,08 & 0,62 & 0,31 & 1,16 & 0,69 & 1,22 \\
\hline Fursenkoina pontoni & 0,00 & 0,25 & 0,00 & 0,00 & 0,00 & 0,00 & 0,22 & 0,00 & 0,00 & 0,00 & 0,00 & 0,00 \\
\hline Hopkinsina pacifica & 2,84 & 4,99 & 3,51 & 0,96 & 2,90 & 2,41 & 3,25 & 3,38 & 3,13 & 2,78 & 2,58 & 4,26 \\
\hline Pseudononion atlanticum & 2,84 & 4,74 & 3,51 & 0,96 & 2,90 & 2,41 & 3,25 & 3,38 & 2,81 & 2,78 & 2,58 & 3,95 \\
\hline Pseudononion grateloupi & 0,00 & 0,00 & 0,00 & 0,00 & 0,00 & 0,00 & 0,00 & 0,00 & 0,00 & 0,00 & 0,00 & 0,30 \\
\hline Pseudononion opima & 0,00 & 0,25 & 0,00 & 0,00 & 0,00 & 0,00 & 0,00 & 0,00 & 0,31 & 0,00 & 0,00 & 0,00 \\
\hline Stanforthia concava & 0,87 & 0,00 & 0,92 & 0,32 & 0,29 & 0,24 & 0,43 & 0,00 & 0,31 & 0,46 & 0,00 & 0,00 \\
\hline Total & 31,00 & 28,43 & 29,15 & 25,72 & 29,28 & 28,92 & 29,07 & 34,46 & 32,81 & 38,66 & 30,81 & 39,21 \\
\hline Ambiente Rico em Oxigênio & & & & & & & & & & & & \\
\hline Cancris sagra & 0,00 & 0,00 & 0,00 & 0,00 & 0,00 & 0,00 & 0,22 & 0,31 & 0,31 & 0,00 & 0,00 & 0,30 \\
\hline Cibicides dispars & 0,87 & 0,25 & 1,11 & 0,96 & 0,29 & 0,72 & 1,52 & 0,62 & 0,63 & 0,23 & 0,69 & 0,61 \\
\hline Cibicides variabilis & 0,22 & 0,50 & 0,55 & 0,00 & 0,58 & 0,00 & 0,00 & 0,31 & 0,31 & 0,00 & 0,00 & 0,30 \\
\hline Cibicides sp. & 0,00 & 0,25 & 0,00 & 0,00 & 0,00 & 0,00 & 0,00 & 0,00 & 0,00 & 0,00 & 0,00 & 0,00 \\
\hline Discorbis williamsoni & 15,07 & 12,72 & 14,58 & 11,90 & 9,57 & 9,88 & 14,32 & 11,38 & 9,06 & 12,04 & 16,01 & 7,90 \\
\hline Eponides repandus & 0,00 & 0,00 & 0,00 & 0,00 & 0,00 & 0,00 & 0,00 & 0,00 & 0,00 & 0,23 & 0,17 & 0,00 \\
\hline Fissurina laevigata & 0,87 & 2,24 & 0,92 & 0,64 & 2,03 & 0,96 & 0,65 & 1,23 & 6,56 & 1,39 & 0,52 & 3,04 \\
\hline Fissurina lucida & 0,22 & 1,00 & 0,00 & 0,00 & 0,29 & 0,24 & 0,00 & 0,31 & 0,94 & 0,93 & 0,17 & 0,30 \\
\hline Fissurina sp. & 0,00 & 0,00 & 0,00 & 0,00 & 0,00 & 0,00 & 0,00 & 0,00 & 0,31 & 0,00 & 0,00 & 0,00 \\
\hline Guttullina plancii & 0,00 & 0,25 & 0,00 & 0,00 & 0,00 & 0,00 & 0,00 & 0,00 & 0,00 & 0,00 & 0,00 & 0,00 \\
\hline Hanzawaia boueana & 2,84 & 3,24 & 3,32 & 3,86 & 7,54 & 5,30 & 2,17 & 6,46 & 6,88 & 3,70 & 2,07 & 3,04 \\
\hline Lagena striata & 0,00 & 0,25 & 0,00 & 0,64 & 0,00 & 0,00 & 0,22 & 0,00 & 0,31 & 0,46 & 0,00 & 0,30 \\
\hline Lagena laevis & 0,00 & 0,00 & 0,18 & 0,00 & 0,29 & 0,00 & 0,00 & 0,31 & 0,00 & 0,46 & 0,00 & 0,00 \\
\hline Lagena sp. & 0,22 & 0,00 & 0,00 & 0,00 & 0,00 & 0,00 & 0,22 & 0,00 & 0,00 & 0,23 & 0,00 & 0,61 \\
\hline Lobatula lobatula & 0,00 & 0,00 & 0,00 & 0,00 & 0,00 & 0,00 & 0,00 & 0,00 & 0,00 & 0,00 & 0,00 & 0,00 \\
\hline Miliamina fusca & 0,00 & 0,25 & 0,18 & 0,00 & 0,00 & 0,00 & 0,00 & 0,00 & 0,00 & 0,00 & 0,00 & 0,00 \\
\hline Neocornubina sp. & 0,22 & 0,25 & 0,92 & 0,32 & 0,29 & 0,24 & 0,65 & 0,62 & 0,94 & 0,00 & 0,00 & 0,00 \\
\hline Oolina hexagona & 0,00 & 0,00 & 0,18 & 0,00 & 0,00 & 0,00 & 0,00 & 0,31 & 0,00 & 0,00 & 0,00 & 0,30 \\
\hline Pyrgo nasuta & 0,87 & 0,75 & 0,92 & 0,32 & 0,00 & 0,00 & 0,43 & 0,00 & 0,63 & 0,46 & 0,34 & 0,91 \\
\hline Pyrgo sp. & 0,00 & 0,50 & 0,18 & 0,00 & 0,00 & 0,00 & 0,00 & 0,00 & 0,00 & 0,00 & 0,00 & 0,00 \\
\hline Quinqueloculina intricata & 0,22 & 0,00 & 0,00 & 0,00 & 0,00 & 0,00 & 0,00 & 0,00 & 0,00 & 0,00 & 0,00 & 0,00 \\
\hline Quinqueloculina milletti & 0,66 & 0,50 & 0,55 & 0,00 & 0,29 & 0,00 & 0,22 & 0,00 & 0,63 & 0,00 & 0,17 & 0,00 \\
\hline Quinqueloculina lamarckiana & 1,53 & 0,75 & 0,55 & 0,32 & 0,58 & 0,00 & 0,87 & 0,00 & 0,31 & 0,46 & 0,34 & 1,52 \\
\hline Quinqueloculina patagonica & 0,87 & 0,25 & 0,18 & 0,00 & 0,00 & 0,00 & 0,43 & 0,31 & 0,00 & 0,00 & 0,17 & 0,00 \\
\hline Quinqueloculina cf. polygona & 0,44 & 0,25 & 0,00 & 0,00 & 0,00 & 0,00 & 0,00 & 0,00 & 0,31 & 0,00 & 0,00 & 0,00 \\
\hline Quinqueloculina atlantica & 0,22 & 0,25 & 0,00 & 0,00 & 0,00 & 0,00 & 0,22 & 0,00 & 0,63 & 0,00 & 0,00 & 0,00 \\
\hline Quinqueloculina sp. & 0,44 & 0,25 & 0,00 & 0,00 & 0,00 & 0,48 & 0,00 & 0,00 & 0,00 & 0,00 & 0,34 & 0,30 \\
\hline Rosalina floridensis & 0,22 & 0,00 & 0,00 & 0,00 & 0,00 & 0,00 & 0,00 & 0,00 & 0,31 & 0,00 & 0,00 & 0,00 \\
\hline Spiroloculina sp. & 0,00 & 0,25 & 0,18 & 0,00 & 0,00 & 0,00 & 0,00 & 0,31 & 0,31 & 0,00 & 0,00 & 0,30 \\
\hline Total & 27,29 & 26,18 & 27,49 & 20,90 & 22,90 & 18,80 & 23,64 & 23,69 & 30,00 & 22,22 & 22,55 & 21,88 \\
\hline Outras Espécies & & & & & & & & & & & & \\
\hline Amphycorina scalaris & 0,00 & 0,25 & 0,18 & 0,00 & 0,00 & 0,00 & 0,00 & 0,00 & 0,31 & 0,46 & 0,00 & 0,00 \\
\hline Glandulina sp. & 0,00 & 0,00 & 0,00 & 0,00 & 0,00 & 0,00 & 0,00 & 0,00 & 0,31 & 0,23 & 0,00 & 0,00 \\
\hline Globulina gibba & 0,00 & 0,00 & 0,18 & 0,00 & 0,00 & 0,00 & 0,00 & 0,00 & 0,00 & 0,00 & 0,00 & 0,00 \\
\hline Oolina caudigera & 0,00 & 0,00 & 0,00 & 0,00 & 0,00 & 0,00 & 0,00 & 0,00 & 0,00 & 0,00 & 0,00 & 0,00 \\
\hline Oolina lineata & 0,00 & 0,25 & 0,00 & 0,00 & 0,00 & 0,00 & 0,00 & 0,00 & 0,31 & 0,00 & 0,00 & 0,00 \\
\hline Oolina mello & 0,00 & 0,00 & 0,00 & 0,00 & 0,00 & 0,00 & 0,00 & 0,00 & 0,00 & 0,00 & 0,00 & 0,00 \\
\hline Oolina vilardeboana & 0,00 & 0,00 & 0,00 & 0,00 & 0,00 & 0,00 & 0,00 & 0,00 & 0,00 & 0,00 & 0,00 & 0,00 \\
\hline Oolina sp. & 0,00 & 0,00 & 0,00 & 0,00 & 0,00 & 0,00 & 0,00 & 0,00 & 0,00 & 0,00 & 0,00 & 0,00 \\
\hline Orthomorphina sp. & 0,00 & 0,00 & 0,00 & 0,00 & 0,00 & 0,00 & 0,00 & 0,00 & 0,00 & 0,00 & 0,17 & 0,00 \\
\hline Polymorphina sp. & 0,00 & 0,00 & 0,00 & 0,00 & 0,00 & 0,00 & 0,00 & 0,00 & 0,00 & 0,00 & 0,00 & 0,00 \\
\hline Jovem rotalineo & 1,97 & 2,74 & 3,51 & 3,22 & 3,19 & 3,13 & 3,25 & 4,31 & 5,63 & 4,17 & 3,27 & 5,78 \\
\hline Jovem cribroelphidium & 0,87 & 0,25 & 0,74 & 0,64 & 0,00 & 0,72 & 0,65 & 0,31 & 1,56 & 0,23 & 1,55 & 0,91 \\
\hline
\end{tabular}


Tabela 10: Frequência relativa de espécies de foraminíferos encontradas no testemunho UB3 - valores percentuais. Acima de 49\% - dominante. Entre 49-25\% - sub-dominante. Entre 25 . 5\% - acessória. Abaixo de 5\% - rara.(continuação)

\begin{tabular}{|c|c|c|c|c|c|c|c|c|c|c|c|}
\hline$\longdiv { \text { UB1 - Profundidade } ( \mathrm { cm } ) }$ & $240-242$ & $250-252$ & $260-262$ & $270-272$ & $280-282$ & $290-292$ & $300-302$ & $310-312$ & $320-322$ & $330-332$ & $340-342$ \\
\hline $\mathrm{AC}$ & & & & & & & & & & & \\
\hline Ammonia parkinsoniana & 0,00 & 0,00 & 0,00 & 0,00 & 0,00 & 0,00 & 0,64 & 0,00 & 0,00 & 0,00 & 0,26 \\
\hline Ammonia tepida & 0,23 & 0,55 & 1,08 & 0,57 & 0,34 & 0,66 & 5,11 & 0,79 & 6,14 & 2,17 & 1,53 \\
\hline Ammonia sp. & 3,70 & 3,02 & 3,89 & 4,79 & 7,63 & 14,07 & 8,31 & 14,96 & 13,16 & 8,70 & 9,44 \\
\hline Cribroelphidium discoidale & 1,85 & 5,22 & 2,81 & 4,02 & 4,24 & 5,49 & 9,90 & 9,45 & 11,40 & 5,80 & 8,16 \\
\hline Cribroelphidium excavatum & 0,23 & 0,27 & 0,22 & 1,34 & 0,85 & 1,54 & 4,15 & 3,15 & 5,26 & 2,54 & 3,57 \\
\hline Cribroelphidium poyeanum & 2,31 & 4,12 & 1,51 & 4,79 & 2,54 & 3,74 & 1,60 & 0,79 & 2,63 & 2,17 & 1,02 \\
\hline Cribroelphidium sp. & 0,00 & 0,00 & 0,00 & 0,38 & 0,51 & 0,22 & 0,32 & 0,00 & 0,88 & 0,00 & 0,77 \\
\hline Pararotalia cananeiaensis & 5,31 & 6,87 & 6,26 & 5,17 & 6,78 & 3,30 & 0,64 & 3,15 & 4,39 & 2,90 & 2,04 \\
\hline Rolshauseni rolshauseni & 0,00 & 0,00 & 0,00 & 0,19 & 0,00 & 0,00 & 0,00 & 0,00 & 0,00 & 0,00 & 0,00 \\
\hline Total & 13,63 & 20,05 & 15,77 & 21,26 & 22,88 & 29,01 & 30,67 & 32,28 & 43,86 & 24,28 & 26,79 \\
\hline ACAS & & & & & & & & & & & \\
\hline Cassidulina crassa forma media & 13,63 & 15,66 & 17,06 & 12,84 & 9,83 & 6,81 & 2,24 & 2,36 & 5,26 & 13,04 & 4,59 \\
\hline Uvigerina bifurcata & 0,00 & 0,27 & 0,00 & 0,00 & 0,17 & 0,00 & 0,00 & 0,00 & 0,00 & 0,00 & 0,00 \\
\hline \begin{tabular}{|l|} 
Total \\
\end{tabular} & 13,63 & 15,93 & 17,06 & 12,84 & 10,00 & 6,81 & 2,24 & 2,36 & 5,26 & 13,04 & 4,59 \\
\hline AT & & & & & & & & & & & \\
\hline Buccela peruviana & 0,00 & 0,00 & 0,00 & 0,00 & 0,00 & 0,00 & 0,00 & 1,57 & 0,88 & 0,00 & 0,00 \\
\hline Globigerinoides ruber & 2,08 & 0,00 & 0,65 & 0,19 & 0,17 & 0,00 & 0,32 & 0,79 & 0,00 & 0,00 & 0,00 \\
\hline Globocassidulina subglobosa & 0,23 & 0,00 & 0,00 & 0,38 & 0,68 & 0,00 & 0,32 & 0,00 & 0,00 & 0,00 & 0,00 \\
\hline Lenticulina sp. & 0,00 & 0,55 & 0,00 & 0,00 & 0,17 & 0,00 & 0,00 & 0,00 & 0,00 & 0,00 & 0,00 \\
\hline Cassidulina minuta & 0,23 & 0,82 & 0,00 & 0,19 & 0,34 & 0,00 & 0,64 & 0,00 & 0,00 & 0,36 & 0,00 \\
\hline Cassidulina sp. & 0,00 & 0,00 & 0,00 & 0,00 & 0,34 & 0,00 & 0,00 & 0,79 & 0,00 & 0,00 & 0,00 \\
\hline Uvigerina peregrina & 4,85 & 5,49 & 2,16 & 6,13 & 5,42 & 1,32 & 0,32 & 2,36 & 0,88 & 0,00 & 0,00 \\
\hline Total & 8,08 & 9,62 & 5,62 & 9,96 & 10,17 & 2,86 & 1,60 & 7,09 & 3,51 & 1,09 & 1,28 \\
\hline M.O. & & & & & & & & & & & \\
\hline Bolivina compacta & 0,23 & 0,82 & 0,00 & 0,19 & 0,85 & 0,66 & 0,00 & 0,00 & 0,00 & 0,36 & 0,26 \\
\hline Bolivina ordinaria & 0,00 & 0,00 & 0,22 & 0,38 & 0,85 & 1,32 & 0,32 & 1,57 & 0,00 & 1,45 & 0,00 \\
\hline Bolivina pulchella & 31,64 & 14,56 & 25,49 & 11,11 & 22,20 & 26,37 & 46,65 & 18,11 & 16,67 & 20,29 & 43,37 \\
\hline Bolivina translucens & 0,00 & 0,27 & 0,00 & 0,00 & 0,00 & 0,00 & 0,00 & 0,00 & 0,00 & 0,00 & 0,00 \\
\hline Bolivina sp. & 0,00 & 0,00 & 0,00 & 0,00 & 0,00 & 0,00 & 0,00 & 0,00 & 0,00 & 0,00 & 0,26 \\
\hline Brizalina stiatula & 6,00 & 9,34 & 5,62 & 7,28 & 8,81 & 8,35 & 3,19 & 4,72 & 4,39 & 7,25 & 3,83 \\
\hline Bulimina elongata & 0,00 & 0,00 & 0,00 & 0,19 & 0,34 & 0,22 & 0,00 & 0,00 & 0,00 & 0,00 & 0,00 \\
\hline Bulimina marginata & 0,69 & 2,75 & 2,81 & 2,87 & 2,71 & 1,32 & 0,00 & 1,57 & 1,75 & 0,72 & 1,28 \\
\hline Buliminella elegantissima & 0,23 & 1,92 & 0,65 & 4,60 & 1,69 & 1,32 & 0,64 & 2,36 & 1,75 & 1,09 & 1,79 \\
\hline Fursenkoina pontoni & 0,00 & 0,00 & 0,00 & 0,00 & 0,17 & 0,22 & 0,00 & 0,00 & 0,00 & 0,36 & 0,26 \\
\hline Hopkinsina pacifica & 5,31 & 5,22 & 4,32 & 7,85 & 4,41 & 6,81 & 1,60 & 14,17 & 15,79 & 6,16 & 5,87 \\
\hline Pseudononion atlanticum & 5,31 & 4,95 & 3,67 & 7,66 & 4,07 & 6,81 & 1,60 & 14,17 & 14,91 & 6,16 & 4,34 \\
\hline Pseudononion grateloupi & 0,00 & 0,27 & 0,00 & 0,00 & 0,00 & 0,00 & 0,00 & 0,00 & 0,88 & 0,00 & 0,51 \\
\hline Pseudononion opima & 0,00 & 0,00 & 0,65 & 0,19 & 0,34 & 0,00 & 0,00 & 0,00 & 0,00 & 0,00 & 1,02 \\
\hline Stanforthia concava & 0,00 & 0,00 & 1,08 & 0,38 & 0,68 & 0,88 & 0,00 & 0,00 & 0,00 & 0,72 & 0,26 \\
\hline Total & 44,34 & 35,71 & 40,60 & 35,44 & 43,22 & 49,45 & 53,99 & 44,09 & 40,35 & 41,67 & 58,16 \\
\hline $\mid$\begin{tabular}{|l|} 
Ambiente Rico em Oxigênio \\
\end{tabular} & & & & & & & & & & & \\
\hline Cancris sagra & 0,00 & 0,55 & 0,43 & 0,00 & 0,00 & 0,00 & 0,00 & 0,00 & 0,00 & 0,00 & 0,00 \\
\hline Cibicides dispars & 0,00 & 0,55 & 0,43 & 0,38 & 0,34 & 0,88 & 0,00 & 0,79 & 0,88 & 0,00 & 0,00 \\
\hline Cibicides variabilis & 0,00 & 0,55 & 0,00 & 0,00 & 0,00 & 0,44 & 0,00 & 0,00 & 0,00 & 0,36 & 0,51 \\
\hline Cibicides sp. & 0,00 & 0,00 & 0,00 & 0,00 & 0,17 & 0,00 & 0,00 & 0,00 & 0,88 & 0,00 & 0,00 \\
\hline Discorbis williamsoni & 6,70 & 9,89 & 10,58 & 7,09 & 8,47 & 4,84 & 0,96 & 1,57 & 1,75 & 6,52 & 1,28 \\
\hline Eponides repandus & 0,00 & 0,27 & 0,00 & 0,00 & 0,00 & 0,44 & 0,00 & 0,00 & 0,00 & 0,00 & 0,51 \\
\hline Fissurina laevigata & 4,62 & 0,55 & 2,16 & 2,30 & 1,19 & 0,88 & 0,32 & 0,79 & 0,00 & 2,17 & 0,26 \\
\hline Fissurina lucida & 0,92 & 0,00 & 0,22 & 0,38 & 0,17 & 0,00 & 0,00 & 0,00 & 0,00 & 0,00 & 0,00 \\
\hline Fissurina sp. & 0,00 & 0,00 & 0,00 & 0,19 & 0,00 & 0,00 & 0,00 & 0,00 & 0,00 & 0,00 & 0,00 \\
\hline Guttullina plancii & 0,00 & 0,00 & 0,22 & 0,00 & 0,00 & 0,00 & 0,00 & 0,00 & 0,00 & 0,00 & 0,00 \\
\hline Hanzawaia boueana & 2,31 & 1,37 & 3,02 & 3,83 & 1,53 & 1,10 & 0,32 & 2,36 & 0,00 & 3,26 & 0,51 \\
\hline Lagena striata & 0,23 & 0,55 & 0,00 & 0,38 & 0,00 & 0,22 & 0,64 & 0,00 & 0,88 & 0,00 & 0,51 \\
\hline Lagena laevis & 0,00 & 0,00 & 0,22 & 0,38 & 0,00 & 0,00 & 0,32 & 0,00 & 0,00 & 0,36 & 0,26 \\
\hline Lagena sp. & 0,23 & 0,27 & 0,00 & 0,38 & 0,00 & 0,22 & 0,00 & 0,00 & 0,00 & 0,00 & 0,00 \\
\hline Lobatula lobatula & 0,00 & 0,27 & 0,00 & 0,00 & 0,00 & 0,00 & 0,00 & 0,00 & 0,00 & 0,00 & 0,00 \\
\hline Miliamina fusca & 0,00 & 0,00 & 0,00 & 0,00 & 0,00 & 0,00 & 0,00 & 0,00 & 0,00 & 0,00 & 0,00 \\
\hline Neocornubina sp. & 0,00 & 0,55 & 0,00 & 0,00 & 0,00 & 0,00 & 0,00 & 0,00 & 0,00 & 0,00 & 0,00 \\
\hline Oolina hexagona & 0,00 & 0,00 & 0,00 & 0,00 & 0,17 & 0,00 & 0,00 & 0,00 & 0,00 & 0,36 & 0,00 \\
\hline Pyrgo nasuta & 0,00 & 0,27 & 0,00 & 0,19 & 0,00 & 0,00 & 1,60 & 0,00 & 0,00 & 0,72 & 1,02 \\
\hline Pyrgo sp. & 0,23 & 0,00 & 0,00 & 0,00 & 0,00 & 0,00 & 0,00 & 0,00 & 0,00 & 0,00 & 0,00 \\
\hline Quinqueloculina intricata & 0,00 & 0,00 & 0,00 & 0,00 & 0,00 & 0,00 & 0,00 & 0,00 & 0,00 & 0,00 & 0,00 \\
\hline Quinqueloculina milletti & 0,00 & 0,00 & 0,00 & 0,00 & 0,00 & 0,00 & 0,00 & 0,00 & 0,00 & 0,00 & 0,00 \\
\hline Quinqueloculina lamarckiana & 0,00 & 0,27 & 0,43 & 0,19 & 0,00 & 0,00 & 3,51 & 0,79 & 0,00 & 0,36 & 0,00 \\
\hline Quinqueloculina patagonica & 0,00 & 0,27 & 0,22 & 0,00 & 0,00 & 0,00 & 0,00 & 1,57 & 0,00 & 0,00 & 0,00 \\
\hline Quinqueloculina cf. polygona & 0,00 & 0,00 & 0,00 & 0,00 & 0,00 & 0,00 & 0,00 & 0,00 & 0,00 & 0,00 & 0,00 \\
\hline Quinqueloculina atlantica & 0,00 & 0,00 & 0,00 & 0,00 & 0,00 & 0,00 & 0,00 & 1,57 & 0,00 & 0,00 & 0,00 \\
\hline Quinqueloculina sp. & 0,00 & 0,00 & 0,00 & 0,00 & 0,00 & 0,00 & 0,00 & 0,00 & 0,88 & 0,00 & 0,00 \\
\hline Rosalina floridensis & 0,00 & 0,00 & 0,00 & 0,00 & 0,00 & 0,00 & 0,32 & 0,00 & 0,00 & 0,00 & 0,00 \\
\hline Spiroloculina sp. & 0,46 & 0,00 & 0,22 & 0,19 & 0,17 & 0,00 & 0,00 & 0,00 & 0,00 & 0,36 & 0,00 \\
\hline Total & 16,17 & 19,78 & 19,65 & 21,46 & 14,41 & 10,33 & 8,95 & 14,17 & 7,89 & 15,58 & 6,89 \\
\hline Outras espécies & & & & & & & & & & & \\
\hline Amphycorina scalaris & 0,00 & 0,00 & 0,00 & 0,00 & 0,17 & 0,00 & 0,00 & 0,00 & 0,00 & 0,00 & 0,00 \\
\hline Glandulina sp. & 0,23 & 0,00 & 0,00 & 0,00 & 0,00 & 0,00 & 0,00 & 0,00 & 0,00 & 0,00 & 0,00 \\
\hline Globulina gibba & 0,00 & 0,00 & 0,00 & 0,00 & 0,00 & 0,00 & 0,00 & 0,00 & 0,00 & 0,00 & 0,00 \\
\hline Oolina caudigera & 0,00 & 0,00 & 0,22 & 0,00 & 0,00 & 0,00 & 0,00 & 0,00 & 0,00 & 0,00 & 0,00 \\
\hline Oolina lineata & 0,46 & 0,00 & 0,00 & 0,00 & 0,00 & 0,00 & 0,00 & 0,00 & 0,00 & 0,00 & 0,00 \\
\hline Oolina mello & 0,00 & 0,00 & 0,00 & 0,19 & 0,00 & 0,00 & 0,00 & 0,00 & 0,00 & 0,00 & 0,00 \\
\hline Oolina vilardeboana & 0,00 & 0,00 & 0,00 & 0,00 & 0,00 & 0,00 & 0,00 & 0,00 & 0,00 & 0,00 & 0,00 \\
\hline Oolina sp. & 0,00 & 0,00 & 0,00 & 0,00 & 0,00 & 0,00 & 0,00 & 0,00 & 0,00 & 0,00 & 0,00 \\
\hline Orthomorphina sp. & 0,00 & 0,00 & 0,00 & 0,00 & 0,00 & 0,00 & 0,00 & 0,00 & 0,00 & 0,00 & 0,00 \\
\hline Polymorphina sp. & 0,00 & 0,00 & 0,00 & 0,00 & 0,00 & 0,00 & 0,00 & 0,00 & 0,00 & 0,00 & 0,00 \\
\hline Jovem rotalineo & 3,70 & 3,02 & 4,10 & 3,83 & 2,20 & 2,86 & 1,28 & 2,36 & 2,63 & 5,07 & 3,57 \\
\hline Jovem cribroelphidium & 1,15 & 1,10 & 0,65 & 2,87 & 1,86 & 1,54 & 1,92 & 3,15 & 0,88 & 1,09 & 1,79 \\
\hline
\end{tabular}




\section{PRANCHA 1}

1. Ammonia parkinsoniana (ventral), $100 \mu \mathrm{m}, \mathrm{UB} 1$ (Enseada do Flamengo)

2. Ammonia tepida (ventral), $30 \mu \mathrm{m}, \mathrm{UB} 1$ (Enseada do Flamengo)

3. Ammonia tepida (umbilical), $30 \mu \mathrm{m}, \mathrm{UB} 1$ (Enseada do Flamengo)

4. Bolivina compacta, $10 \mu \mathrm{m}, \mathrm{UB} 1$ (Enseada do Flamengo)

5. Bolivina pulchella, $30 \mu \mathrm{m}, \mathrm{UB} 1$ (Enseada do Flamengo)

6. Brizalina striatula, $30 \mu \mathrm{m}, \mathrm{UB} 1$ (Enseada do Flamengo)

7. Brizalina striatula, $30 \mu \mathrm{m}, \mathrm{UB} 1$ (Enseada do Flamengo)

8. Bulimina marginata, $20 \mu \mathrm{m}, \mathrm{UB} 1$ (Enseada do Flamengo)

9. Buliminella elegantissima, $20 \mu \mathrm{m}, \mathrm{UB} 1$ (Enseada do Flamengo)

10. Cassidulina crassa forma. media, $30 \mu \mathrm{m}, \mathrm{UB} 1$ (Enseada do Flamengo)

11. Cibicides sp., $30 \mu \mathrm{m}$, UB1 (Enseada do Flamengo)

12. Cribroelphidium discoidale, $100 \mu \mathrm{m}, \mathrm{UB} 1$ (Enseada do Flamengo)

13. Cribroelphidium excavatum, $100 \mu \mathrm{m}, \mathrm{UB} 1$ (Enseada do Flamengo)

14. Cribroelphidium poyeanum, $100 \mu \mathrm{m}, \mathrm{UB} 1$ (Enseada do Flamengo) 

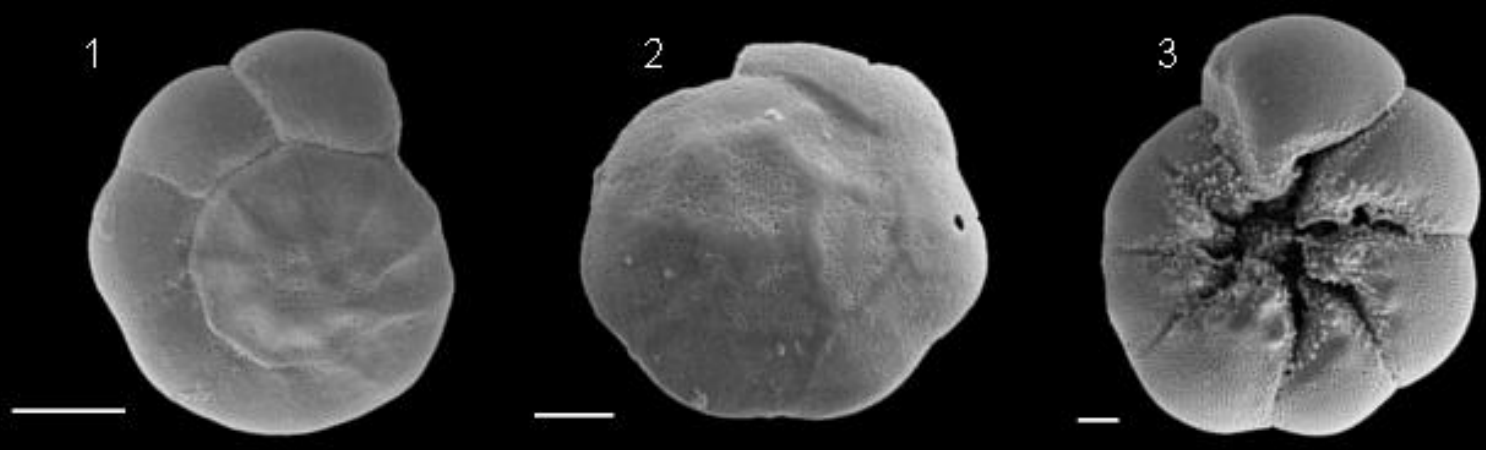

4

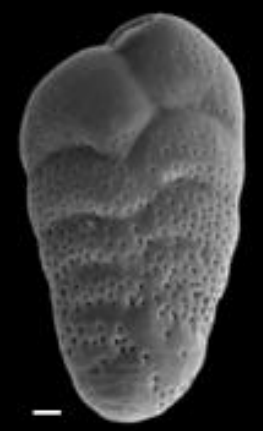

8

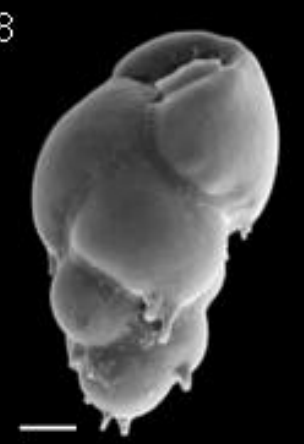

5

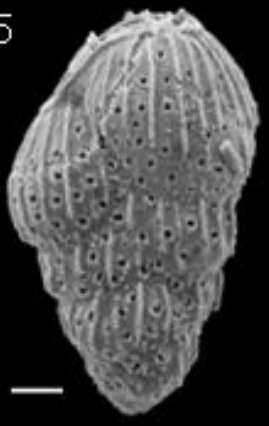

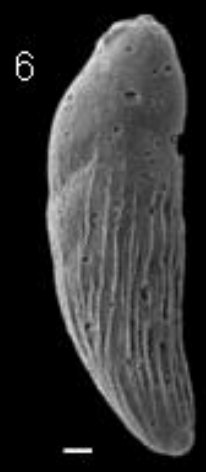
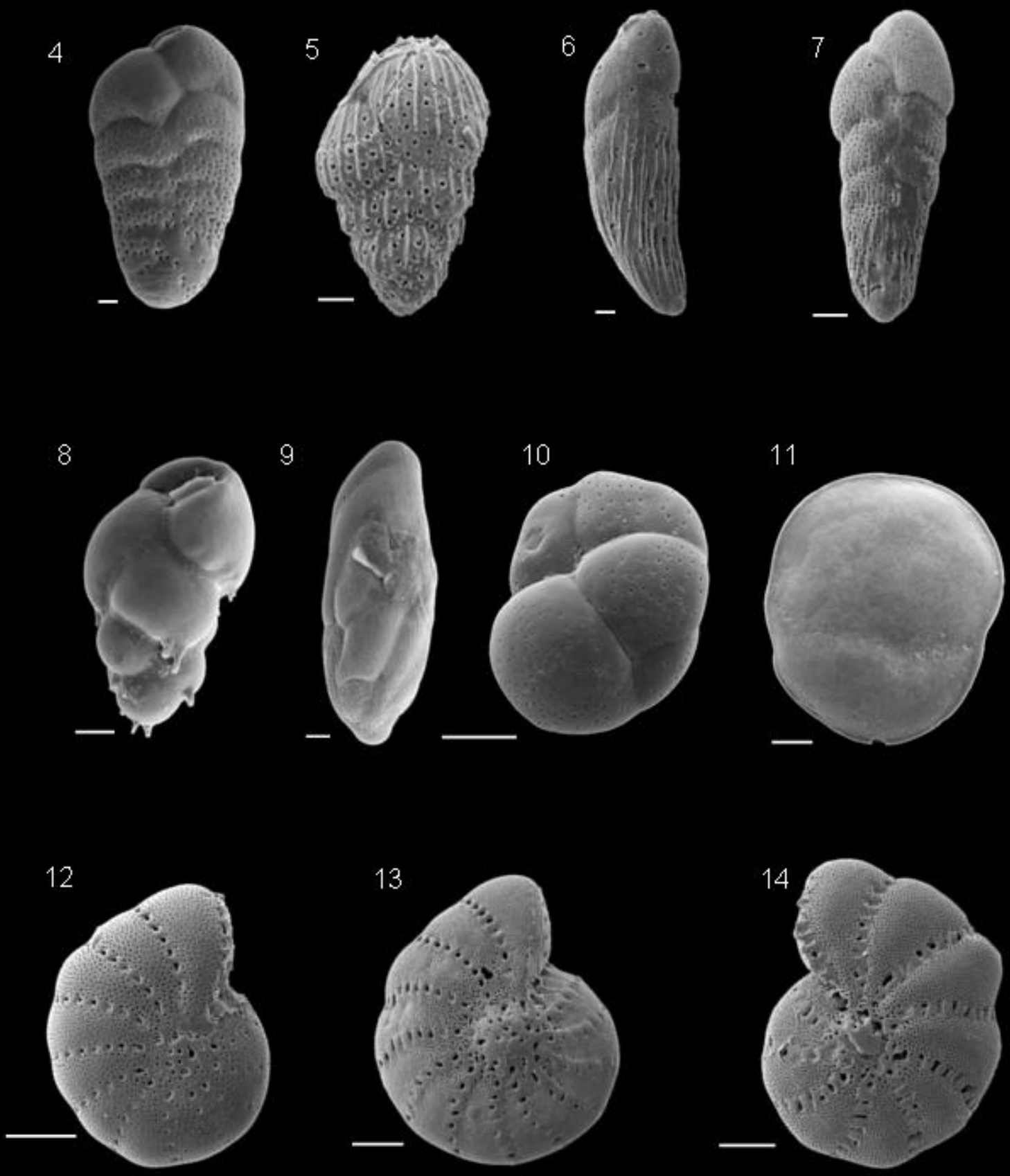


\section{PRANCHA 2}

15. Fissurina laevigata, $20 \mu \mathrm{m}, \mathrm{UB} 1$ (Enseada do Flamengo)

16. Fursenkoina pontoni, $30 \mu \mathrm{m}, \mathrm{UB} 1$ (Enseada do Flamengo)

17. Globocassidulina subglobosa, $20 \mu \mathrm{m}, \mathrm{UB} 1$ (Enseada do Flamengo)

18. Hanzawaia boueana, $30 \mu \mathrm{m}, \mathrm{UB} 1$ (Enseada do Flamengo)

19. Hopkinsina pacifica, $30 \mu \mathrm{m}, \mathrm{UB} 1$ (Enseada do Flamengo)

20. Lagena laevis, $20 \mu \mathrm{m}, \mathrm{UB} 1$ (Enseada do Flamengo)

21. Lagena striata, $30 \mu \mathrm{m}, \mathrm{UB} 1$ (Enseada do Flamengo)

22. Pseudononion atlanticum, $100 \mu \mathrm{m}, \mathrm{UB} 1$ (Enseada do Flamengo)

23. Pyrgo nasuta, $30 \mu \mathrm{m}, \mathrm{UB} 1$ (Enseada do Flamengo)

24. Quinqueloculina atlantica, $200 \mu \mathrm{m}, \mathrm{UB} 1$ (Enseada do Flamengo)

25. Quinqueloculina lamarkiana, $100 \mu \mathrm{m}, \mathrm{UB} 1$ (Enseada do Flamengo)

26. Quinqueloculina patagonica, $30 \mu \mathrm{m}, \mathrm{UB} 1$ (Enseada do Flamengo)

27. Quinqueloculina sp., $30 \mu \mathrm{m}, \mathrm{UB} 1$ (Enseada do Flamengo) 
15
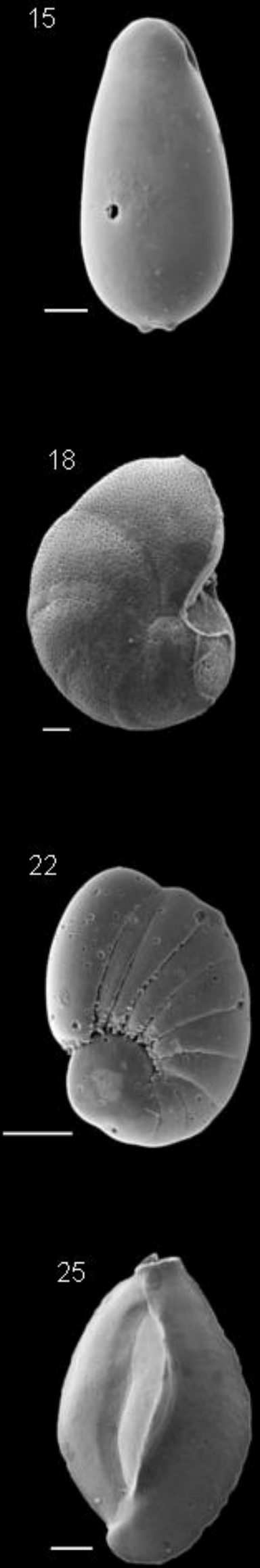

16
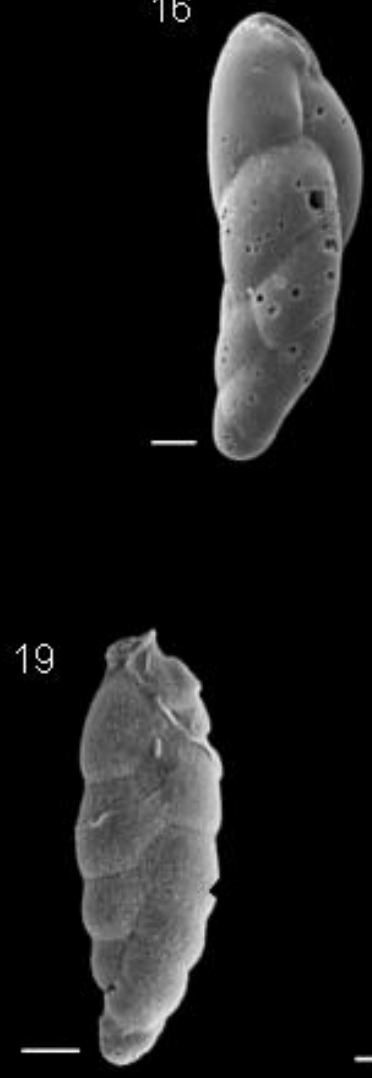

23
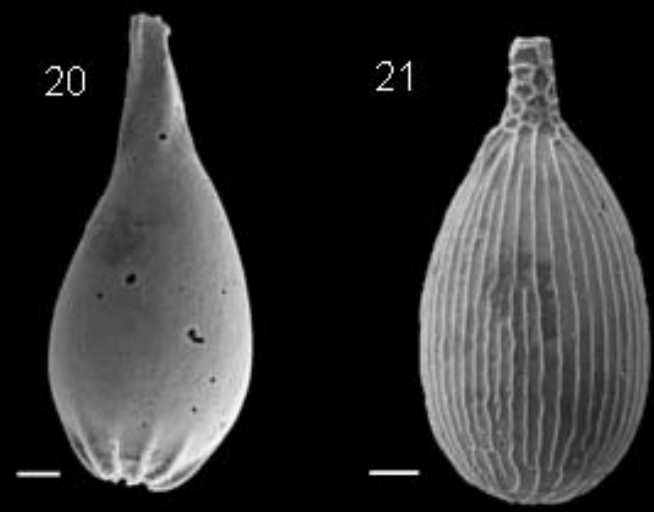

24

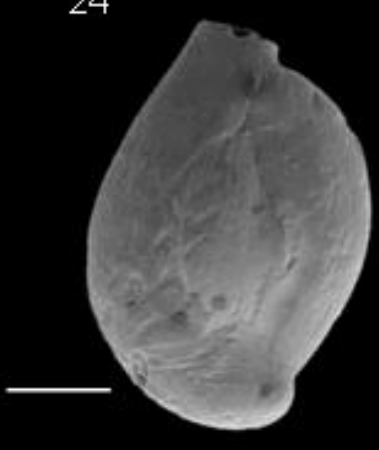

26

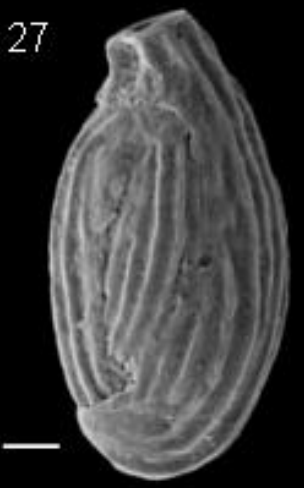




\section{PRANCHA 3}

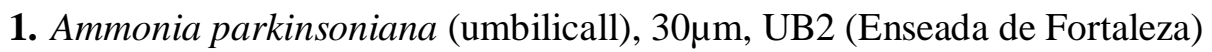

2. Ammonia tepida (ventral), $20 \mu \mathrm{m}, \mathrm{UB} 2$ (Enseada do Flamengo)

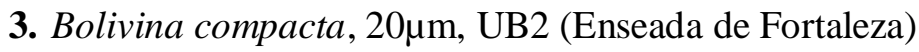

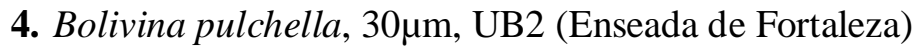

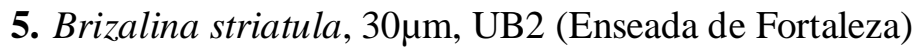

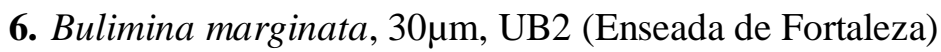

7. Cancris sagra, $30 \mu \mathrm{m}, \mathrm{UB} 2$ (Enseada de Fortaleza)

8. Cassidulina crassa f. media, $20 \mu \mathrm{m}, \mathrm{UB} 2$ (Enseada de Fortaleza)

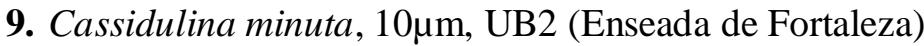

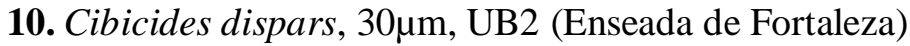

11. Cibicides sp., 30 $\mu \mathrm{m}, \mathrm{UB} 2$ (Enseada de Fortaleza)

12. Cribroelphidium discoidale, $30 \mu \mathrm{m}, \mathrm{UB} 2$ (Enseada de Fortaleza) 

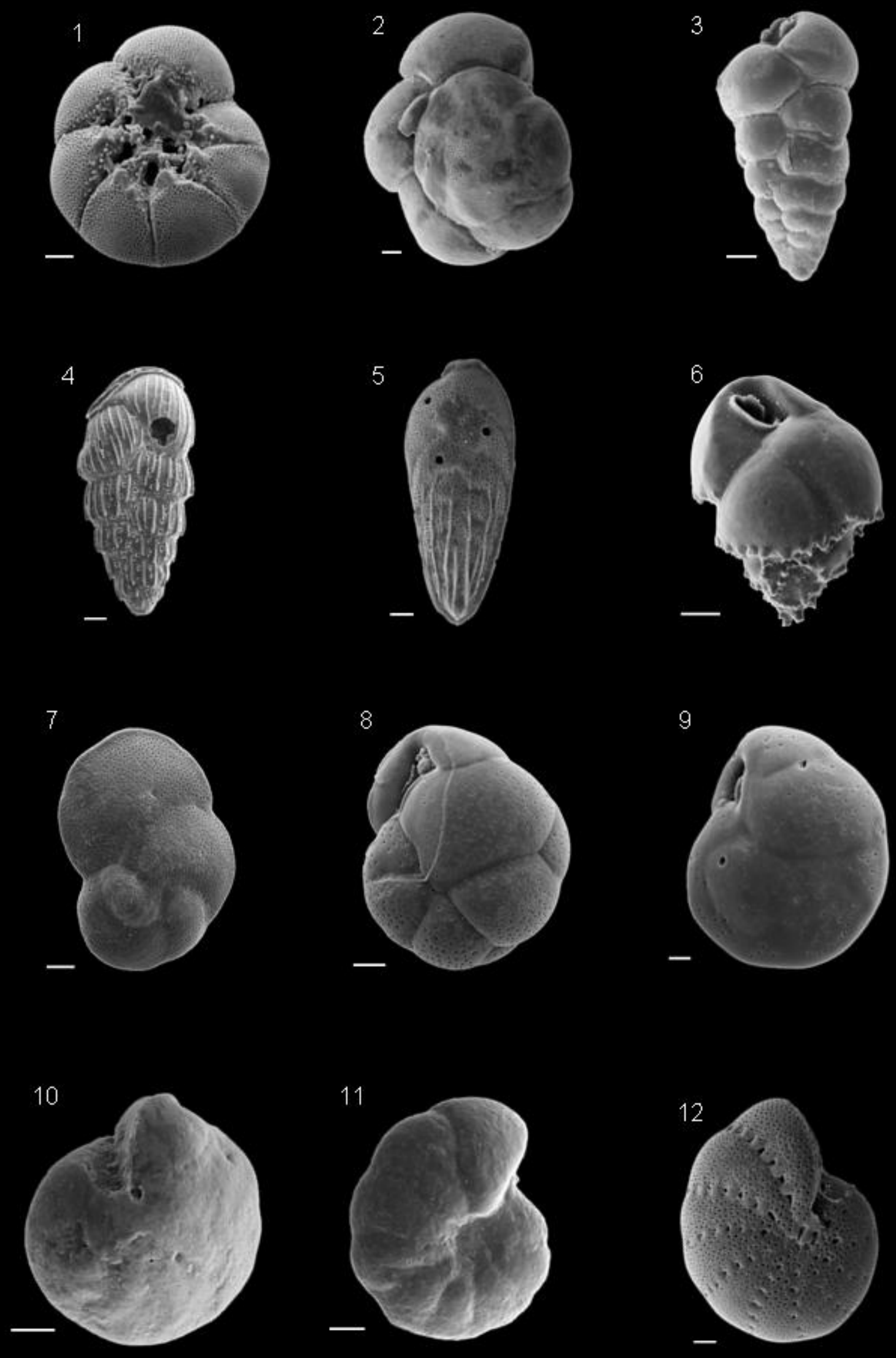


\section{PRANCHA 4}

13. Cribroelphidium excavatum, $100 \mu \mathrm{m}, \mathrm{UB} 2$ (Enseada de Fortaleza)

14. Cribroelphidium poyeanum, $20 \mu \mathrm{m}, \mathrm{UB} 2$ (Enseada do Flamengo)

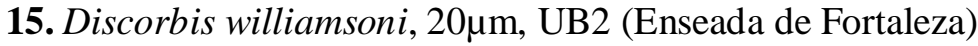

16. Fissurina laevigata, $30 \mu \mathrm{m}, \mathrm{UB} 2$ (Enseada de Fortaleza)

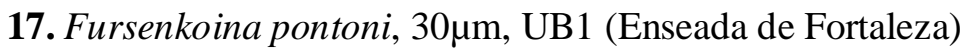

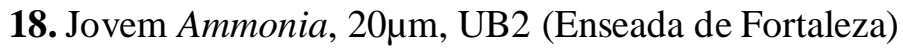

19. Globigerinoides ruber, $30 \mu \mathrm{m}, \mathrm{UB} 2$ (Enseada de fortaleza)

20. Hanzawaia boueana, $30 \mu \mathrm{m}, \mathrm{UB} 2$ (Enseada de Fortaleza)

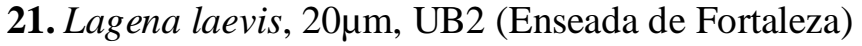

22. Lagena striata, 30 $\mu \mathrm{m}, \mathrm{UB} 2$ (Enseada de Fortaleza)

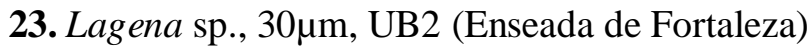

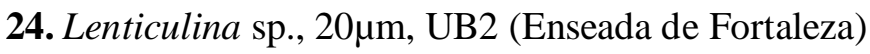



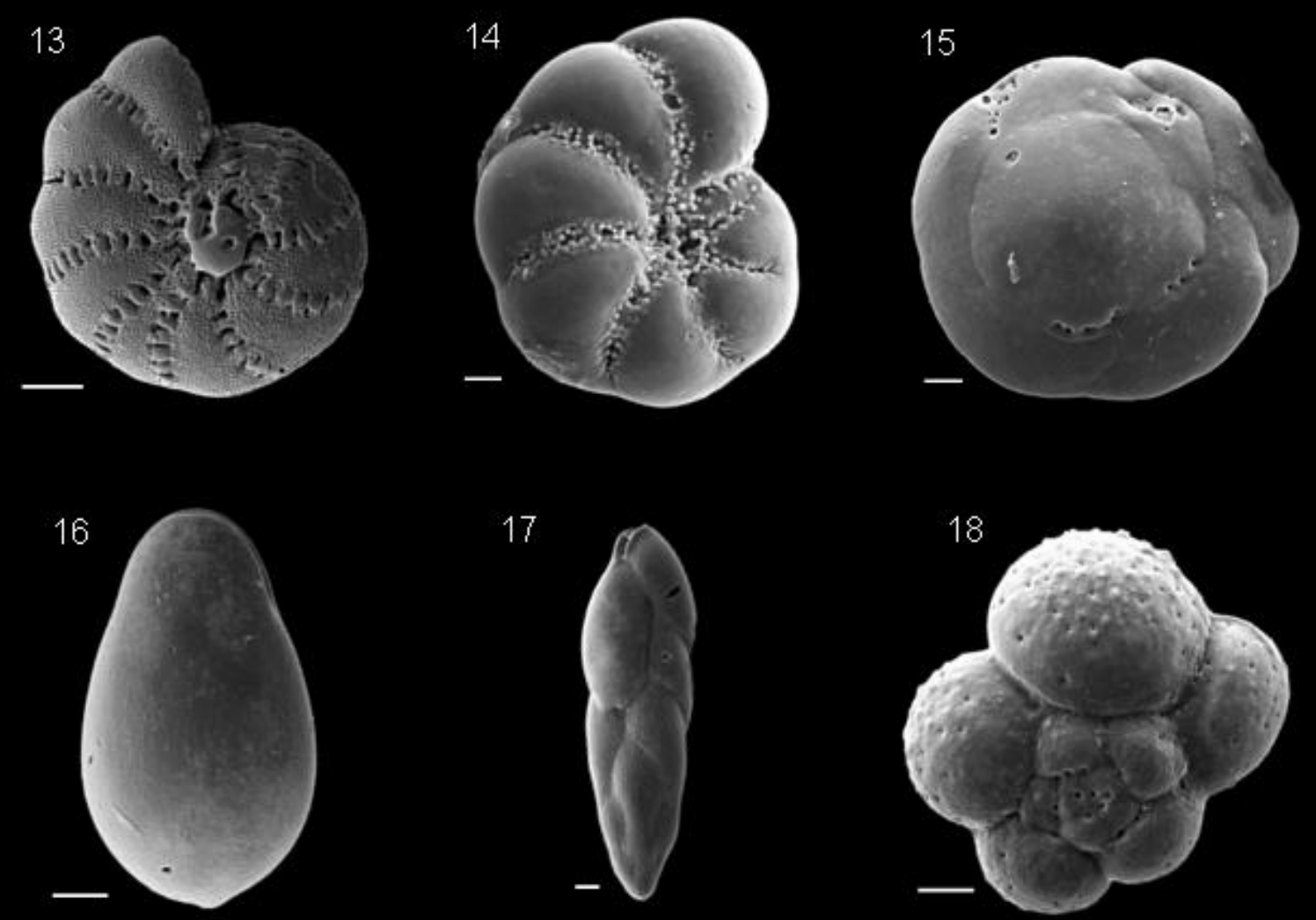

17
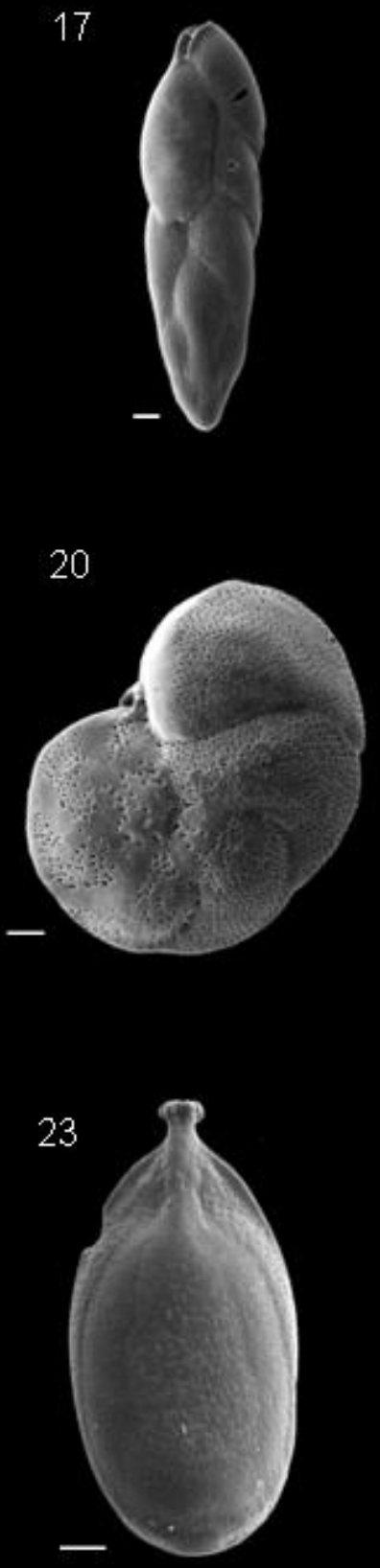
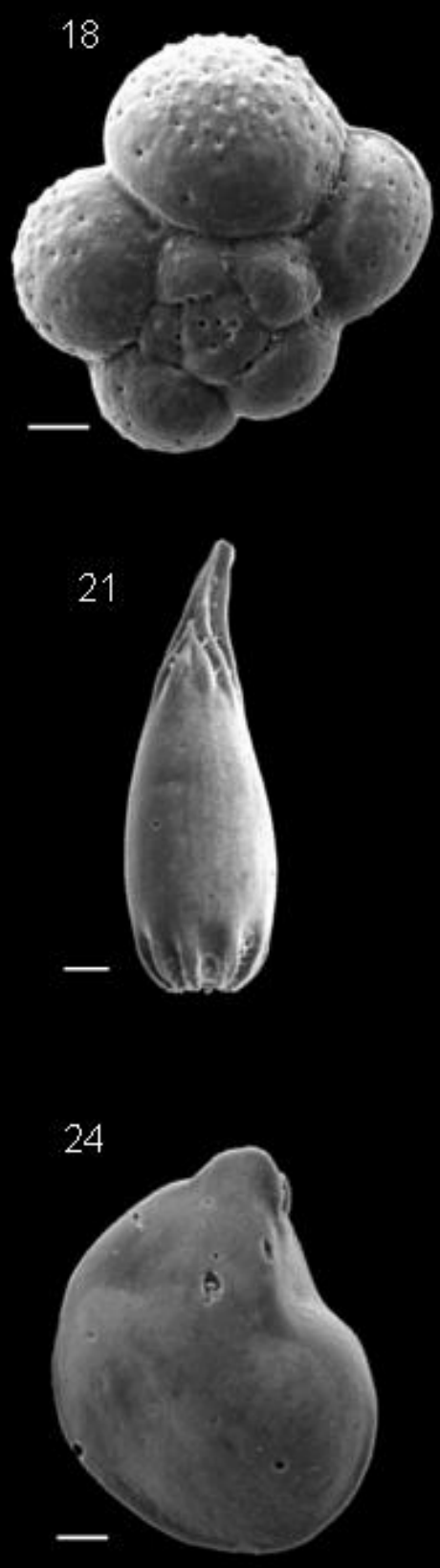


\section{PRANCHA 5}

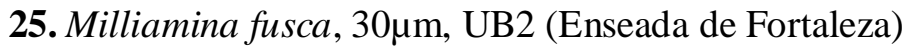

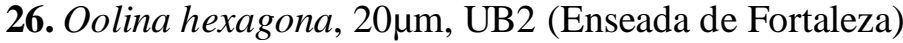

27. Pararotalia cananeiaensis, $20 \mu \mathrm{m}, \mathrm{UB} 2$ (Enseada de Fortaleza)

28. Pseudononion atlanticum, $30 \mu \mathrm{m}, \mathrm{UB} 2$ (Enseada de Fortaleza)

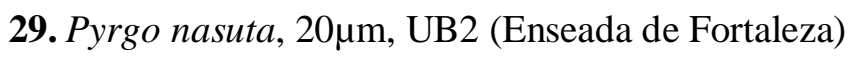

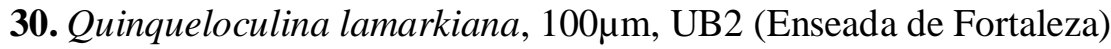

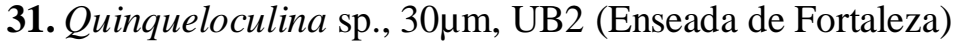

32. Rosalina floridensis, $30 \mu \mathrm{m}, \mathrm{UB} 2$ (Enseada de Fortaleza)

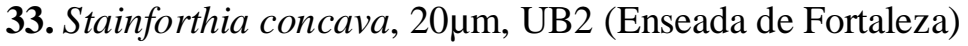

34. Uvigerina peregrina, $20 \mu \mathrm{m}, \mathrm{UB} 2$ (Enseada de Fortaleza) 

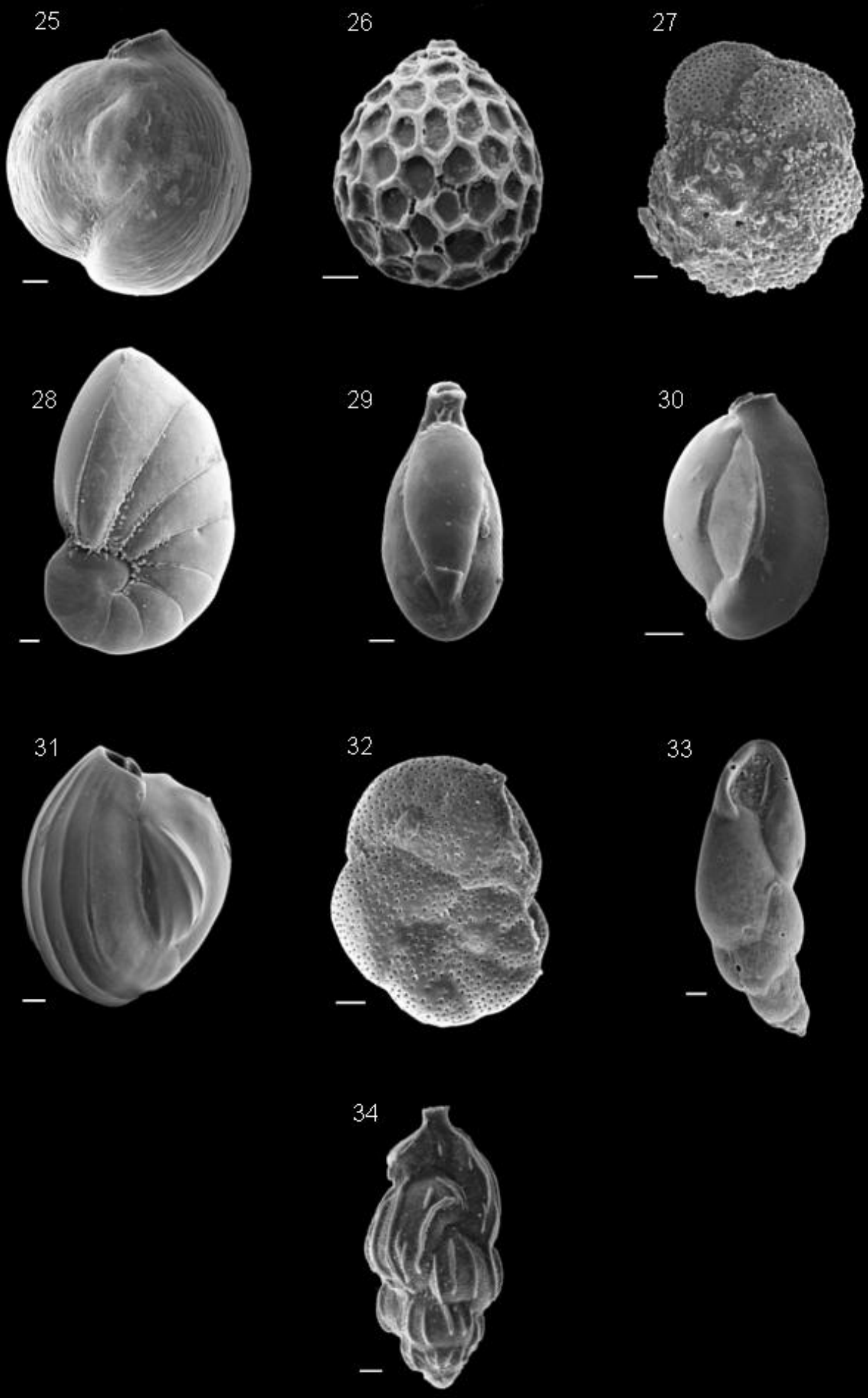


\section{PRANCHA 6 - TAFONOMIA UB1}

1. Bioerosão e abrasão, $30 \mu \mathrm{m}, \mathrm{UB} 1$ (Enseada do Flamengo)

2. Bioerosão, $20 \mu \mathrm{m}, \mathrm{UB} 1$ (Enseada do Flamengo)

3. Bioerosão, 30 $\mu \mathrm{m}$, UB1 (Enseada do Flamengo)

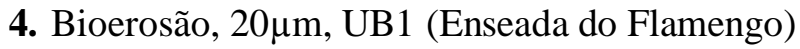

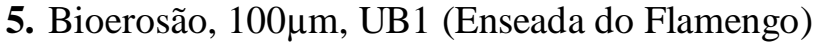

6. Corrosão, $30 \mu \mathrm{m}, \mathrm{UB} 1$ (Enseada do Flamengo)

7. Bioerosão e abrasão, $30 \mu \mathrm{m}, \mathrm{UB} 1$ (Enseada do Flamengo)

8. Corrosão, $200 \mu$ m, UB1 (Enseada do Flamengo) 


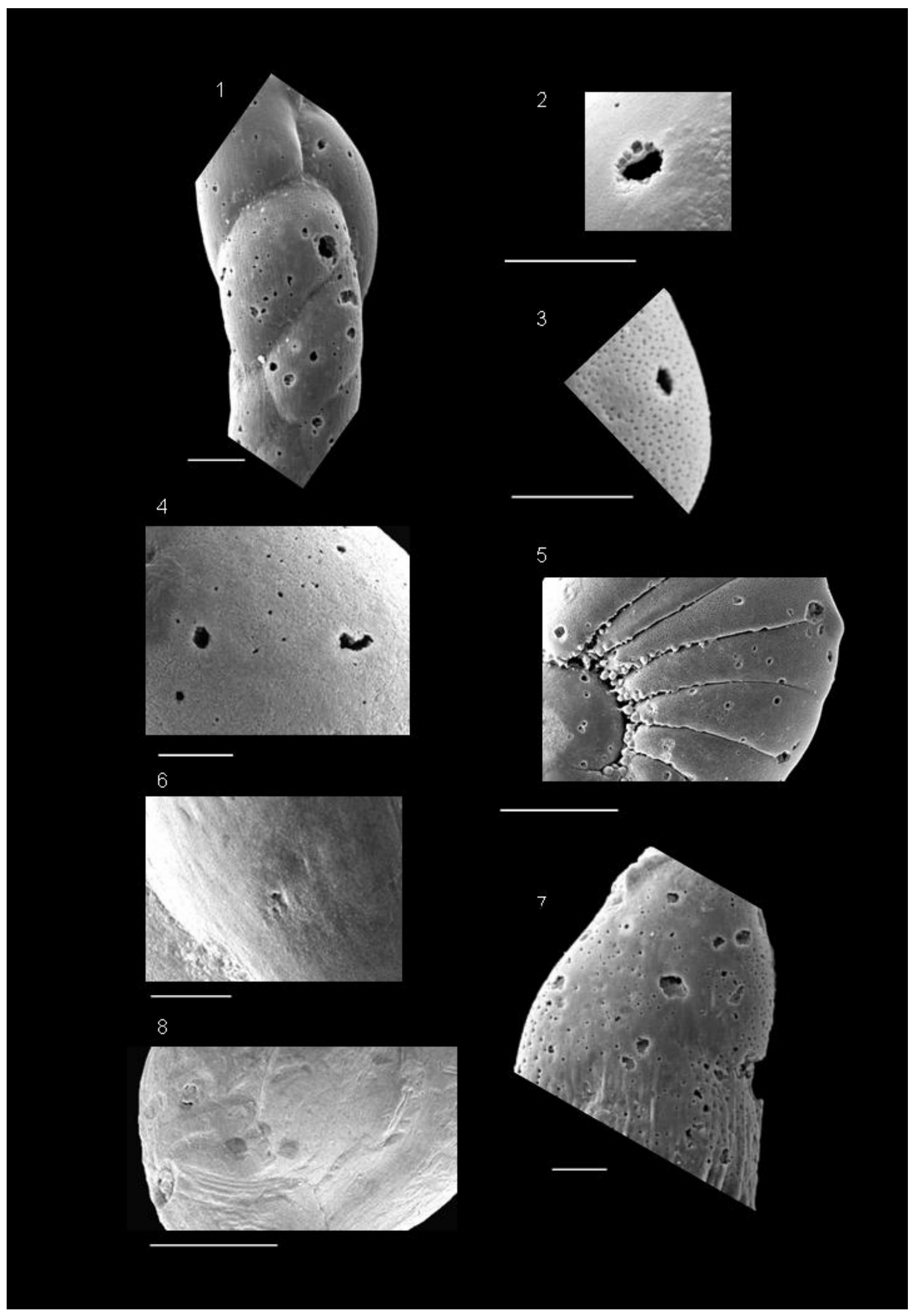




\section{PRANCHA 7 - TAFONOMIA UB3}

1. Bioerosão, $30 \mu \mathrm{m}, \mathrm{UB} 3$ (Enseada de Fortaleza)

2. Bioerosão, 30 $\mu$ m, UB3 (Enseada de Fortaleza)

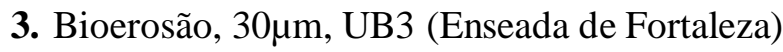

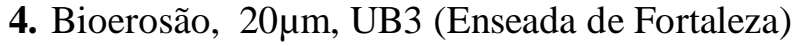

5. Corrosão, 30 $\mu$ m, UB3 (Enseada de Fortaleza)

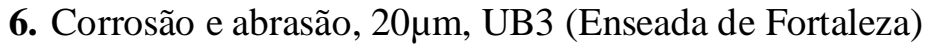

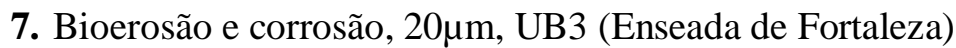




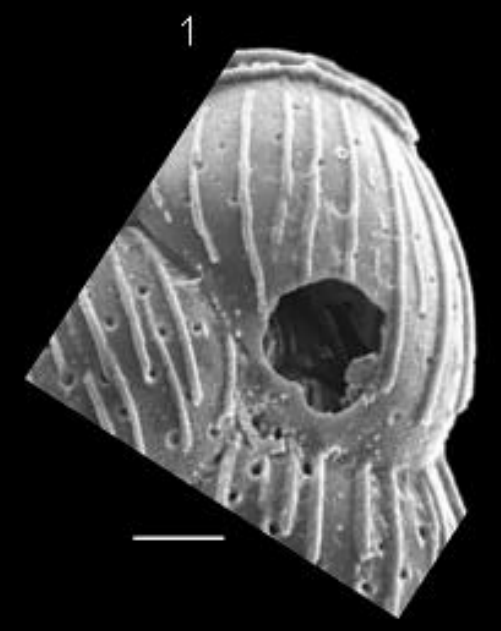

4

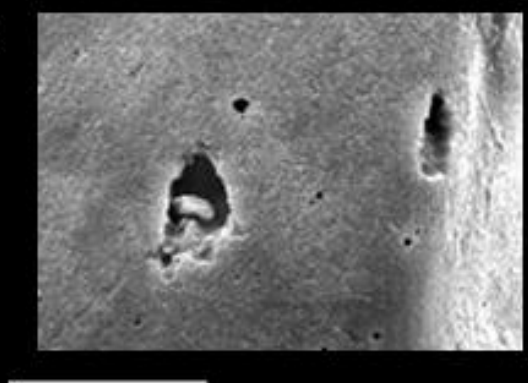

6

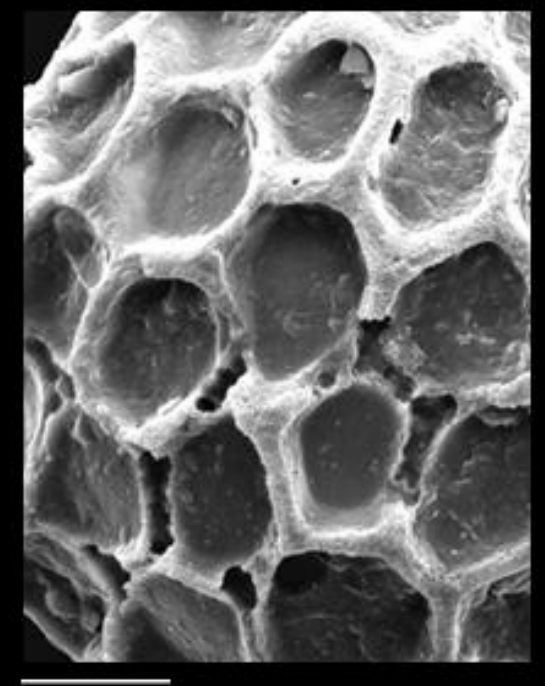

2
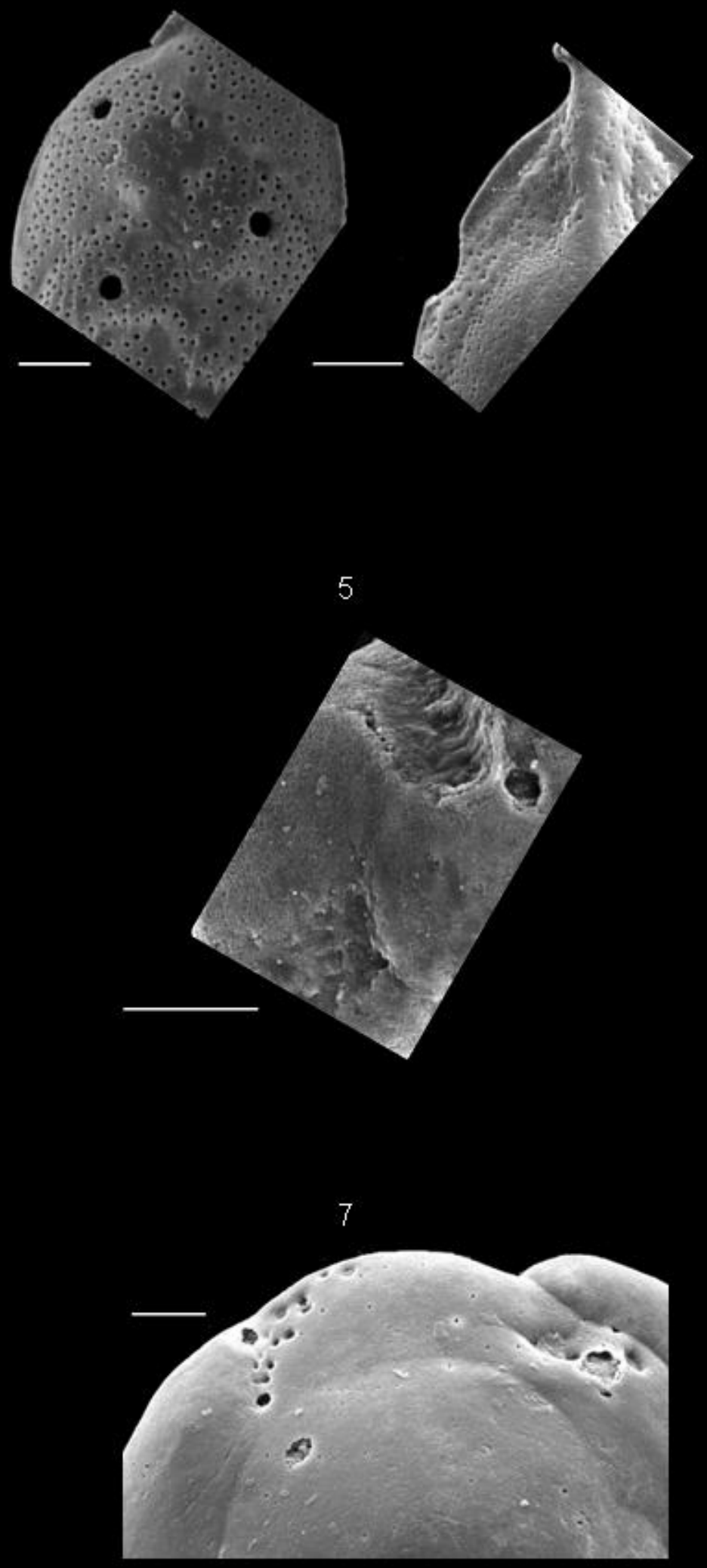
